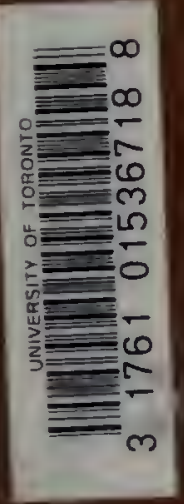





\section{LIBRARY \\ FACULTY OF FORESTRY \\ UHAVERSITY OF TORONTO}

MAR 25010 
3 


\section{Digitized by the Internet Archive in 2007 with funding from Microsoft Corporation}





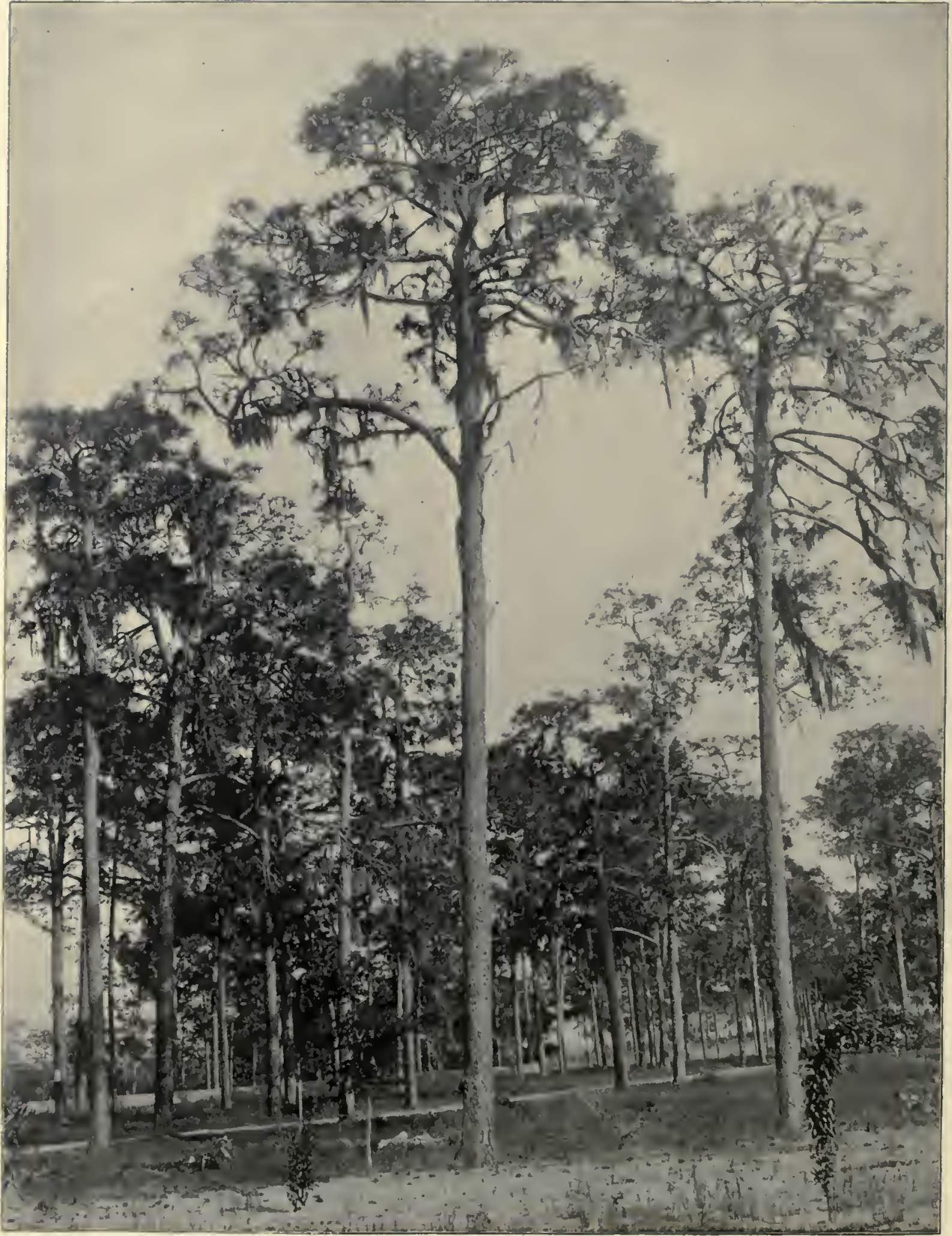


Bulletin No. 13 (REVISED Edition).

\section{U. S. DEPARTMENT OF AGRICULTURE. DIVISION OF FORESTRY.}

\section{TH E}

\section{TINBER PINES OF THE SOUTHERN INITED STITES. \\ BY CHARLES MOHR, Ph. D.}

TOGFTHYR WITH

A IDSCUSSION OF THE STRUCTURE OF THEIR WOOI).

By FILIBERT ROTH.

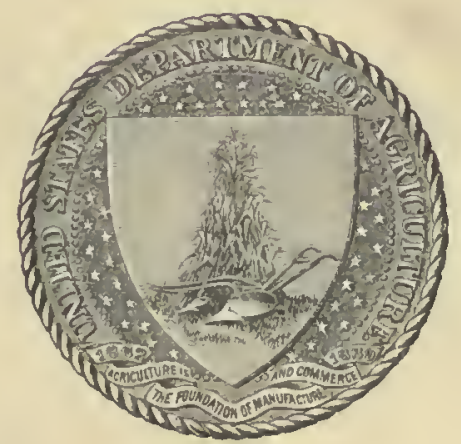

WASHINGTON :

GOVHRNMENT PINTING OFFICE.

$189 \%$. 


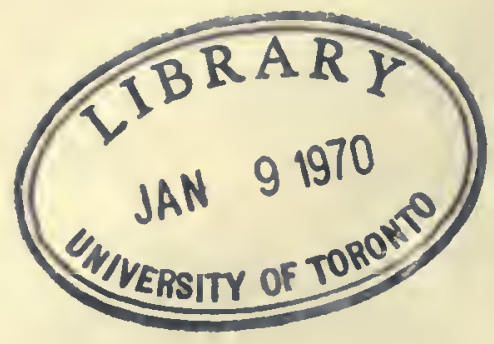

$$
\begin{aligned}
& S D \\
& 397 \\
& P 55 M 6 \\
& 1897
\end{aligned}
$$




\title{
LETTER OF TRANSMITTAL。:
}

\author{
United States Departirent of Agrioulture, " \\ Division of Forestîy, \\ Washington, D. C., Novemberi 1, 1897.
}

SrR: I have the louor to submit herewith for publication a revised and enlarged edition of a series of monographs ou the five pines of economic importance in the Sonthern United States, a result of many years' study by Dr. Charles Molır, the well-known anthority on the botany of the Southern States and agent of the Division of Forestry.

The first draft of these monograplis was prepared several years ago, bnt it was then found that in order to make them fully satisfactory and usefnl to the practitioner much additional information was needed, especially regarding the rate of growtl and other sylvicultnral as well as technological questions. This information lias been gradnally accmunlated as our facilities have pernitted. The extended investigations carried on in this division may be considered quite exhanstive, at least in regard to the mechanical properties of the wood of these pines. An interesting cliapter on the wood structure by Mr. Filibert Roth has been added, and a conparative stidy of the economic, sylvicnltural, and technical characteristics and valne of the pines nuller considcration-a résnmé, as it were, of the contents of the monographs-is to be fonnd in the introluction by the writer.

Advantage lias bcen taken of the opportunity afforded by a call for a second edition to carcfully revise the text of the monographs and record in additional notes results of new investigations.

During the carly snmmer of $1897, \mathrm{Mr}$. Filibert Rotl made an exhaustive study of several localitics in the territory of the Soathern Pines, and his observations, so far as they supplement the cxcellent work of Dr. Mohr, are embodied in brief notes at the end of eaeh monograph. Mr. Roth has also contributed a short sketch of the Pond Pine, which was fonnd to be of greater economic importance than had been known.

The cordial reception which was accorded this bnlletin, and tle large demand which has marle this sceond edition becessary, are a source of great gratification to those interested in its preparation, and show an increasing appreciation of the great economic value of our forest resonrces on the part of the public.

The pincries of the South furnish now, or will in the near future, the most important staples of our limber industry. According as they are treated, carefully or wastefully, they will continue for a longer or shorter time to be a wealth-producing resource of the South. To aid in securing a true conception of the extent, condition, and value of this resonrec, and of the nature, development, and characteristics (botanical, sylvicnltural, and technological) of these pines, these monographs have been writtell, with the hope of ind ncing rational forestry methods in their use and reproduetion. Respectfully,

Hon. JuMes WiLson, B. E. FERNow,
Chief of Division. Secretary of Agriculture. 



\section{CONTENTS.}

Introductiou, $\mathrm{By}, \mathrm{B}, \mathrm{E}, \mathrm{F}$ ER

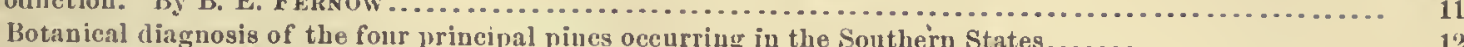

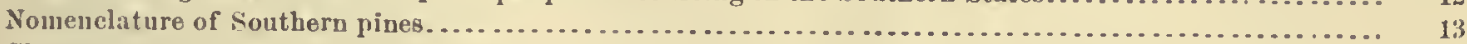

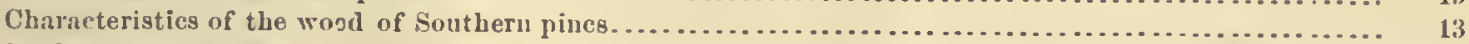

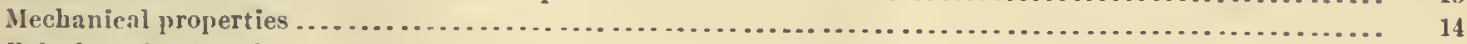

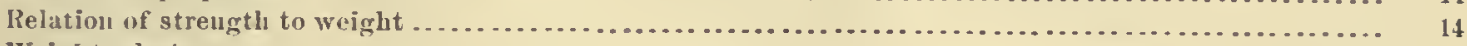

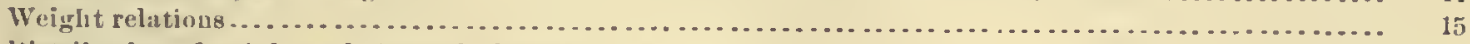

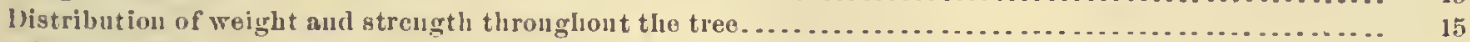

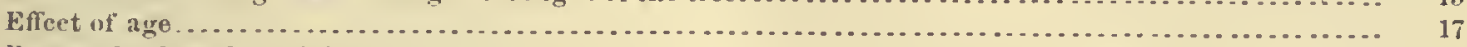

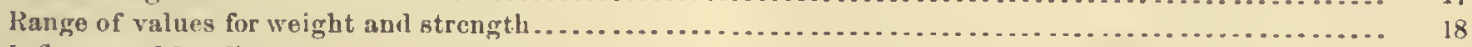

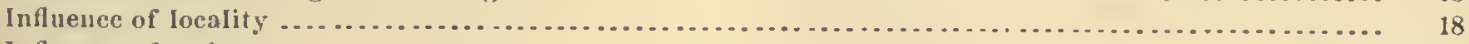

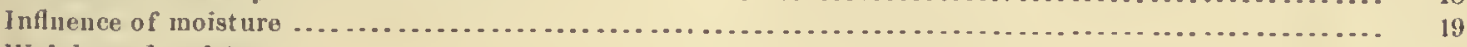

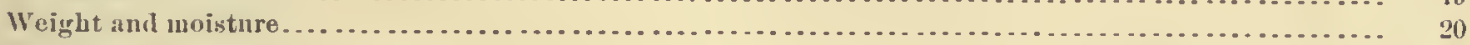

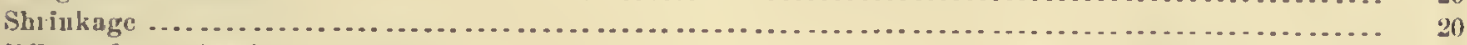

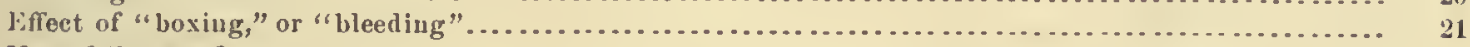

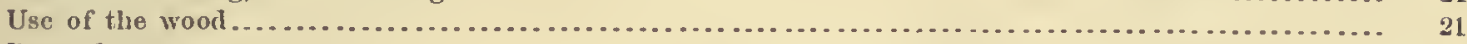

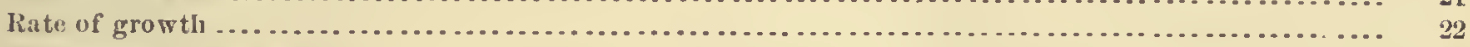

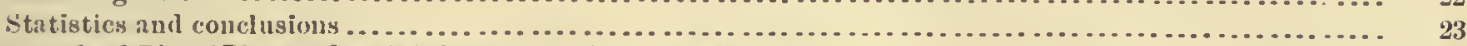

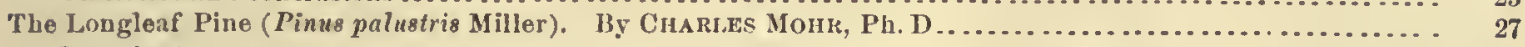

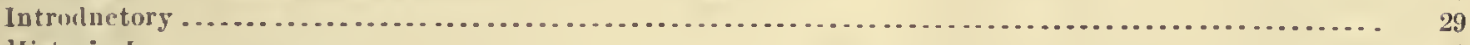

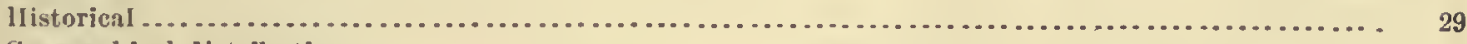

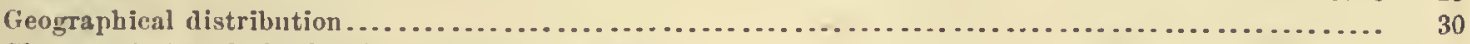

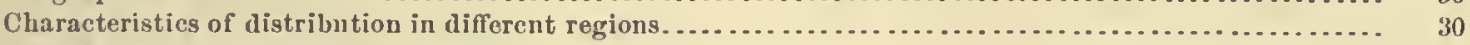

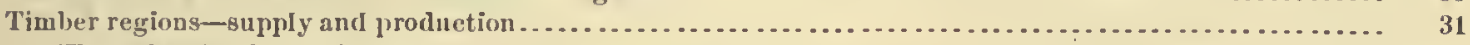

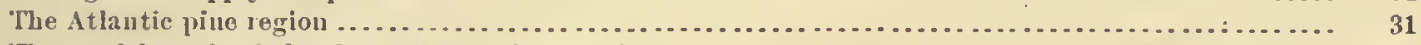

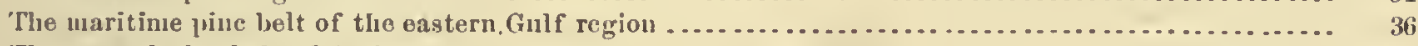

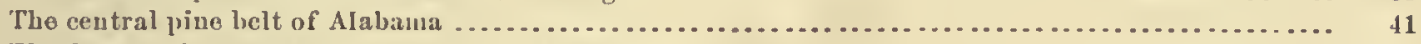

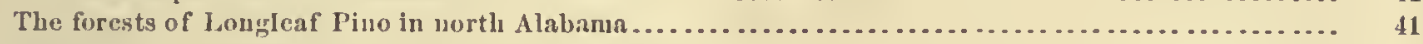

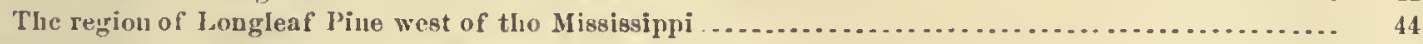

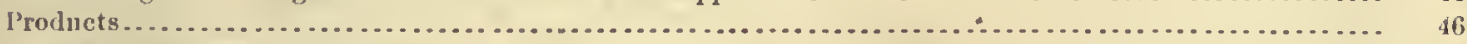

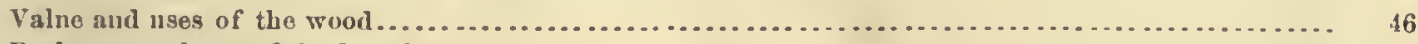

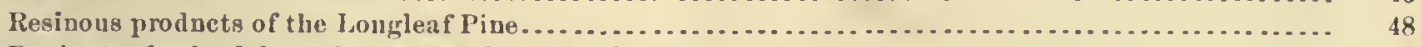

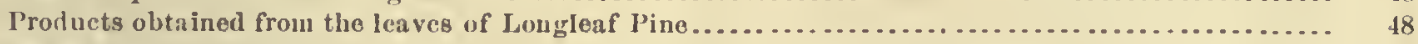

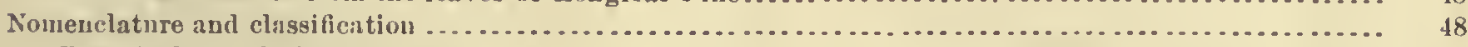

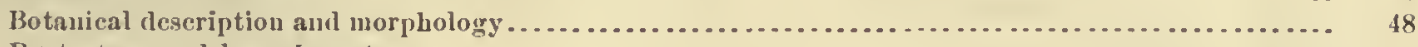

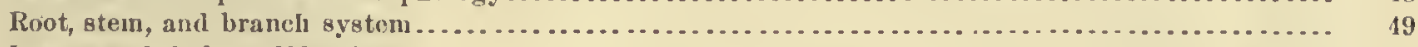

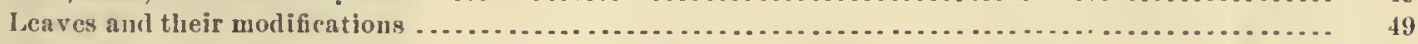

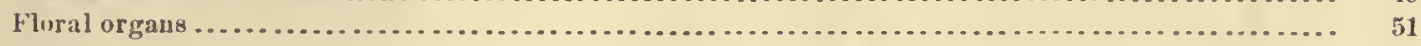

Seeds. . . . . . . . . . . . . . . . . .

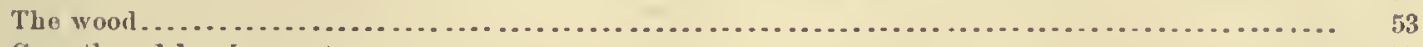

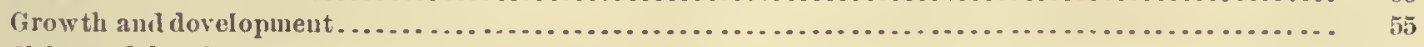

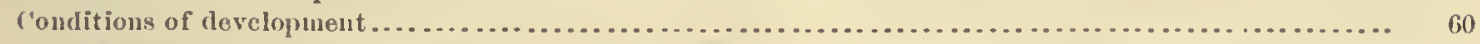

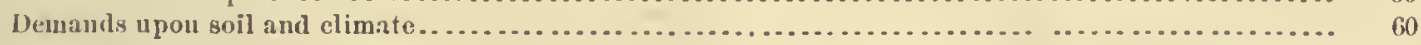

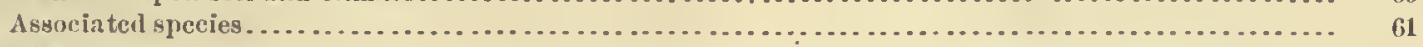

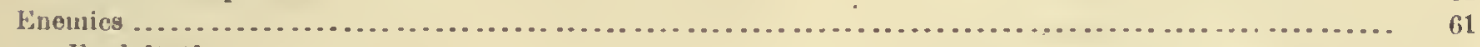

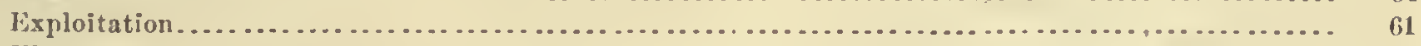

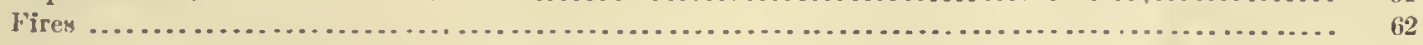

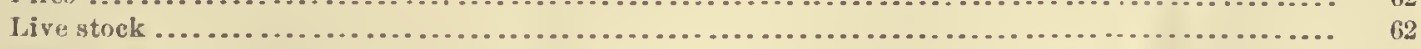

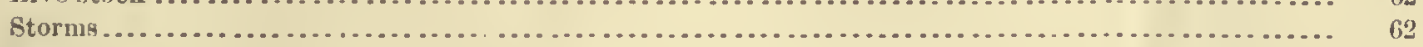

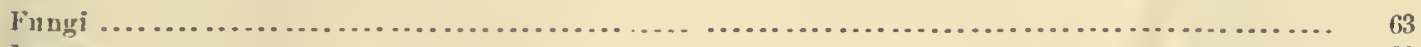

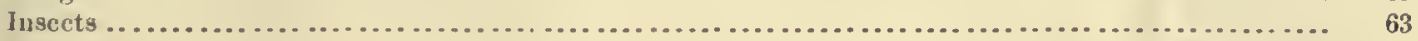


Tho Longleaf Pino (linus palustris Miller). l3y Cuanles Monu, l'h. D.-Continued.

Natural reproduction

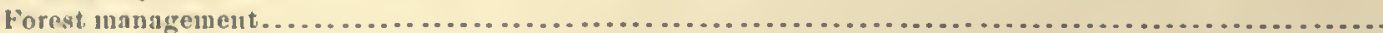

Conclusion

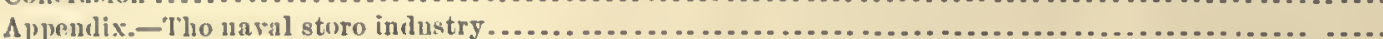

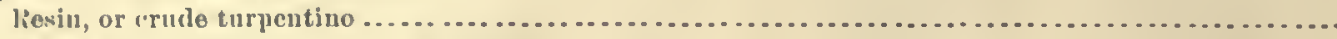

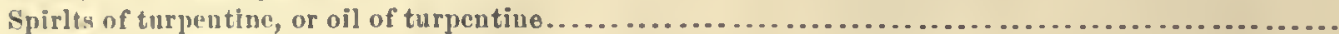

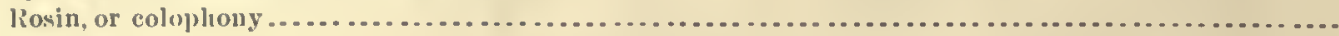

l'ine tar

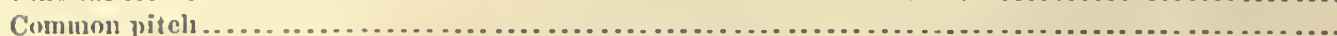

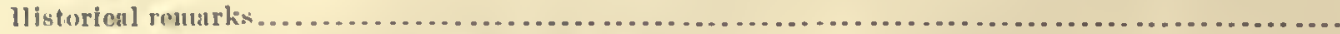

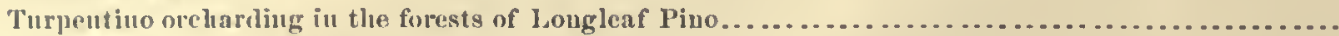

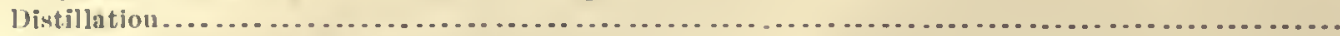

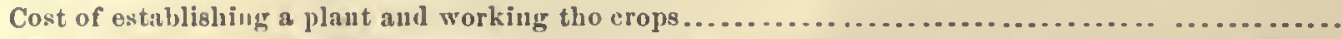

Effocts of the production of naval storos npon the timber, tho lifo of tho tree, and the conditions of the forest...

Longleat Pine in highlauds.

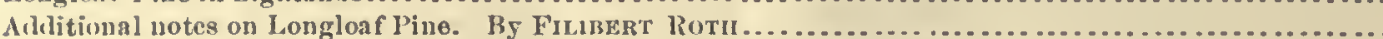

Tho Culan l'ine (Pinus heterophylla (E11.) Sndw.). By Cularlas Molu, Ph. D

Introductory

(ieograplical distribution

l'roducts

Resinous prodncts

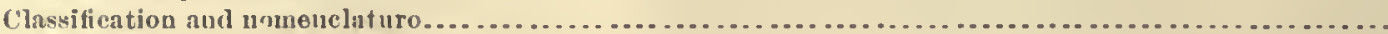

Description aucl morphological elaracters.

Flowers ... . . . . . . . . . . . .

The wool

l'rogress of development.

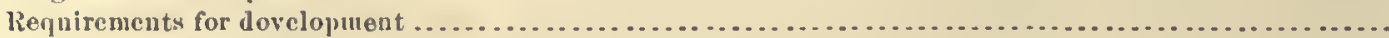

Soil.

Additional notes on Cuban Pine. By Filubert liotu

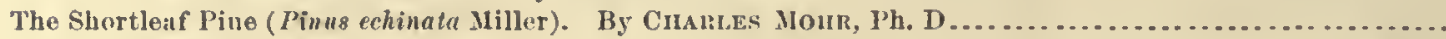
Introductory.

llistorical

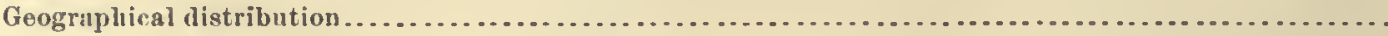

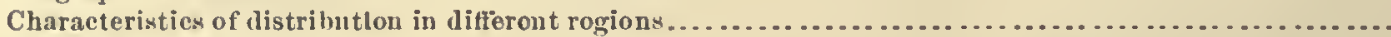

Products.

Nomenclature and classilication.

Botanical description.

lenves.

Flowers.

Cones

Seerl

The wool

of developmient

Soil and elimute

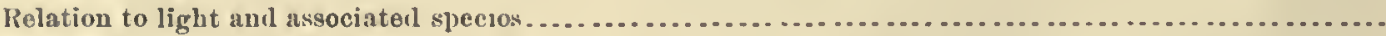

Enemies.

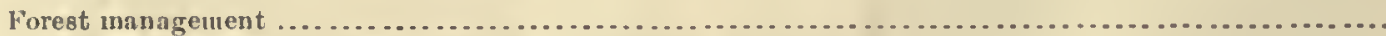

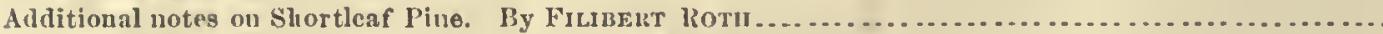

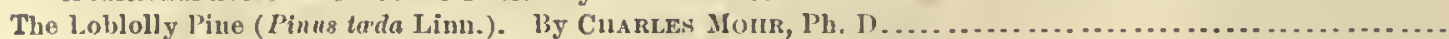

Introduction

llistorieal

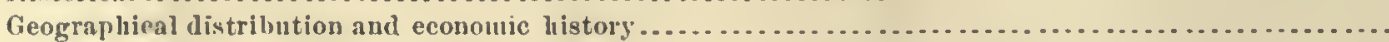

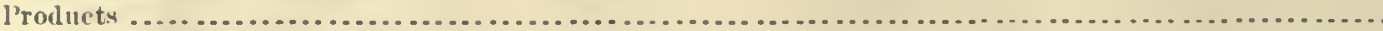

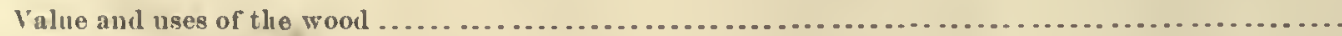

liesiuons produets...

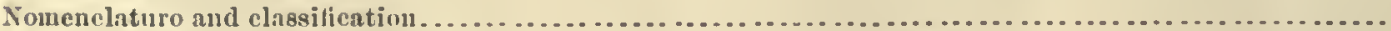

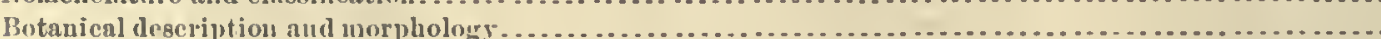

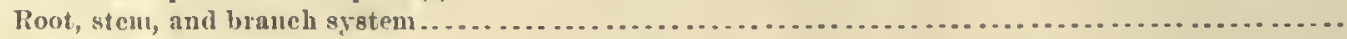

Lenves

Floral organs.

Progress of deyelopment

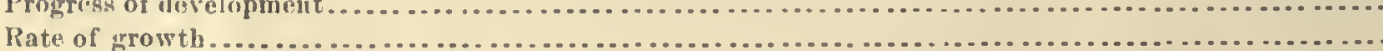


The Loblolly Pine (Pinus tada Linu.). By Cuarles Mour, Ph. D.-Continued.

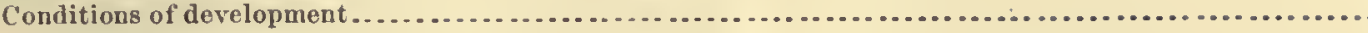

Soil and climate.

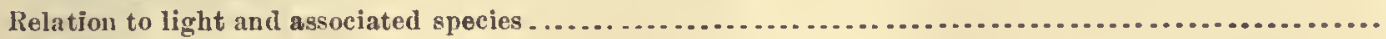

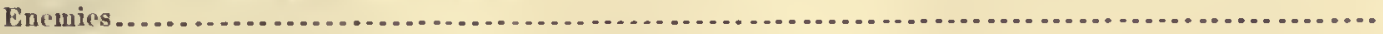

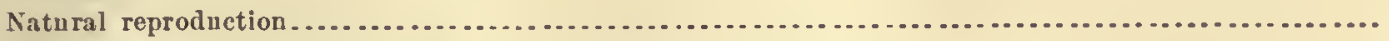

Conclusion

Additional 1 otes on Loblolly Pine. By Filibert Roti

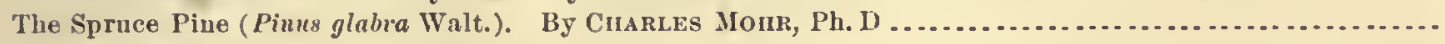
Introunctory

IIistorical

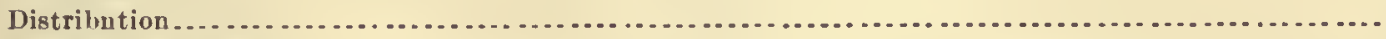

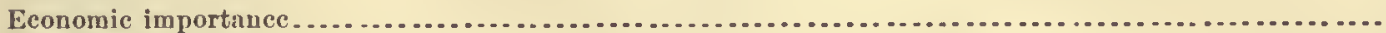

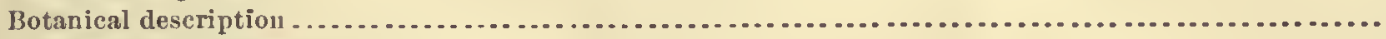

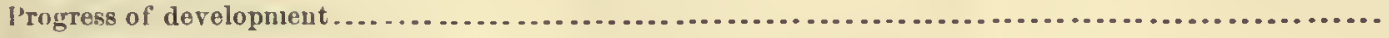

linemies

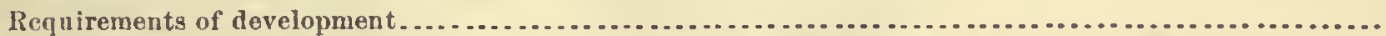

Notes on the strnctare of the wood of five Soutleru pines (Pinus palustrin, heterophylla, echinata, tada, and

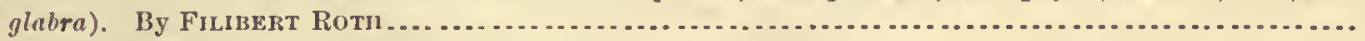

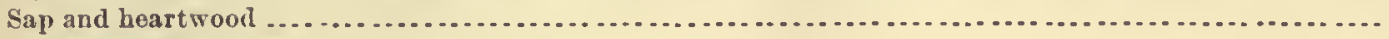

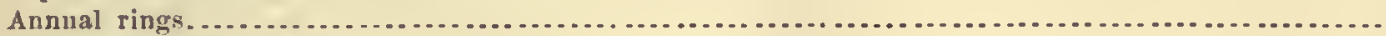

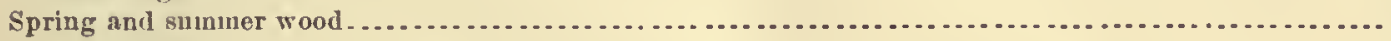

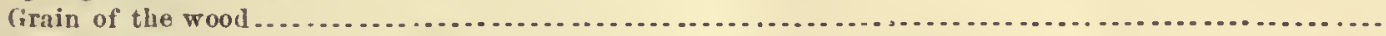

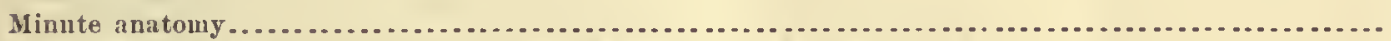

Observations on the Marsl or Poud Pine (Pimus serotina). By Fibibrt Rotir..........................

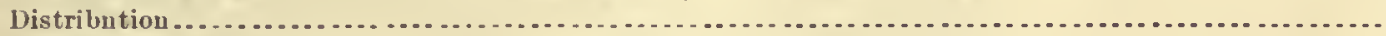

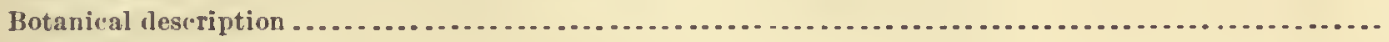

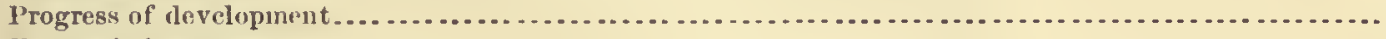

Economic importance... 



\title{
ILLUSTRATIONS.
}

\author{
I'LA'T'ES.
}

Page

I. Longleaf Pine (Pinus yalnstrix) ........................................ Frontispier..

II. Fig. 1.-Longleaf Pine forest in Lonisiana flats, virgin, scorehel by fire, as usual; Fig. 2.Longleaf l'ino forest after removal of merclunutable timber .........................

III. Map showing distribution of Longleaf Piue and Cuban Pinc...........................

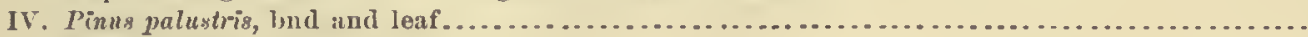

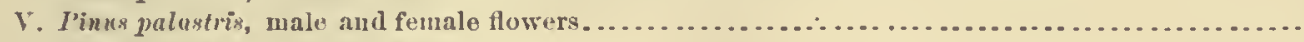

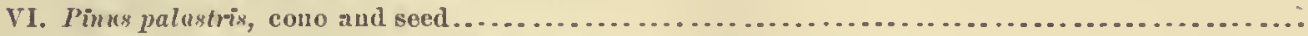

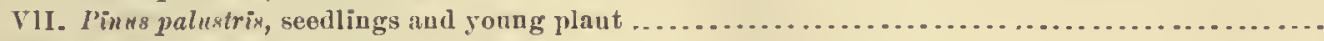

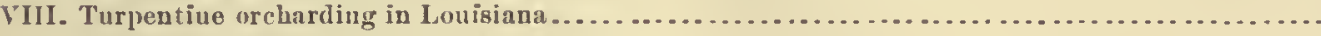

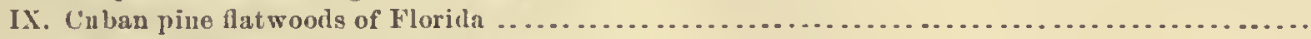

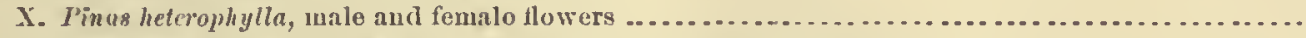

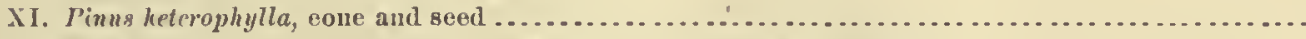

XII. Shortleaf Pine (Pinus eehinata), forest growu specimens in Missonri.....................

XIII. Shortleaf Pino (Pinns echinata), a roadside specimen iu North Carolina....................

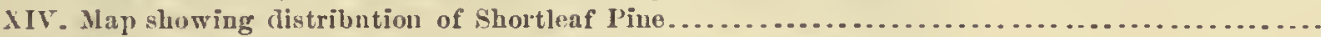

XV. Pinus echinata seedling; malo and female flower, and leaf seetions . . . . . . . . . . . . . . . . . . .

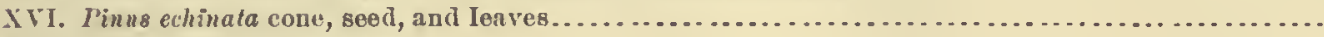

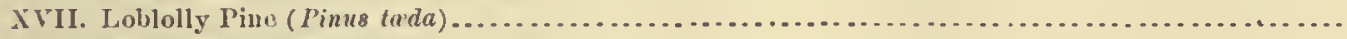

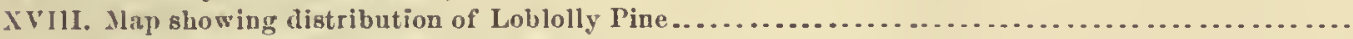

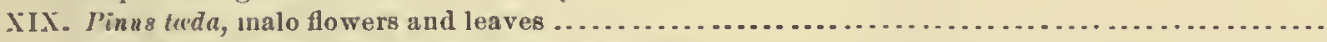

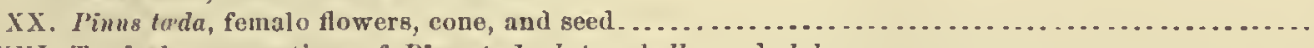

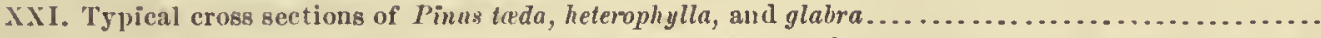

XXII. Typical cross sections of Pinus palnstris and eehinata, and radial sections of Pinus palustris and glabra

XXIII. Radial sections of Pinus eehivata and heterophylla.

XXIV. Rarlial seetions of Pinus tada and tangential sections of Pinus palustris and eehinata ............

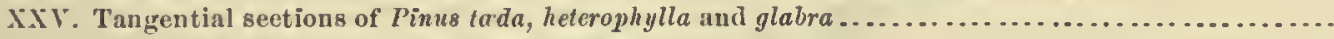

IXVI. 'Tangential sections of Pinus eehinata, heterophylla, and glabra, slowing number and distribution

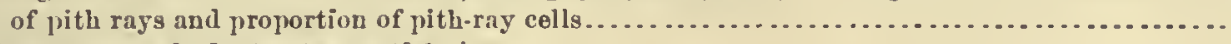

XxVII. Transverse resin duets-tangential views.

\section{FIGURES.}

Hig. 1. I liagran showing variation of weight with height of tree

2. Schematic section thronglı stem of Longleaf Pine, showing variation of specilie wciglit witl height,

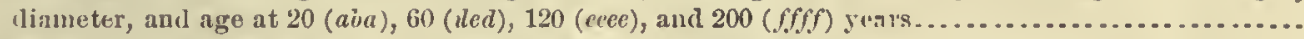

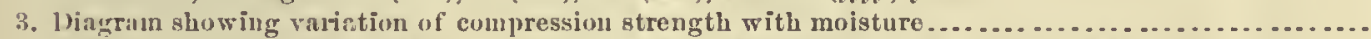

4. 1)iagrau showing loss of water in kiln drying and reabsorption in air, shrinking ausl swelling......

5. 1)iagram showing comparative prouress of height growth in average trees......................

6. Diagrau showing eomparative progress of dianeter growth in average troes.....................

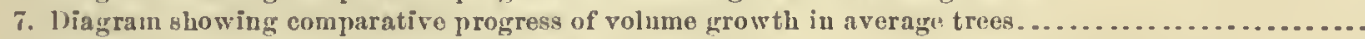

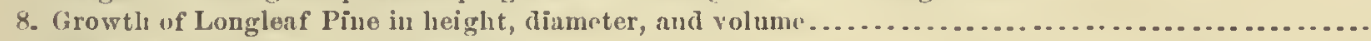

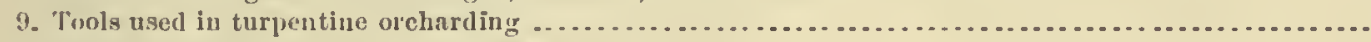

10. Inprovel methoil of tu rpentine orehardiur . . . . . . .

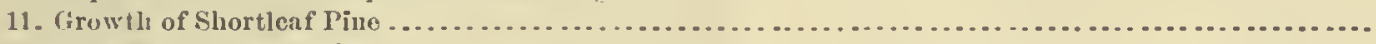

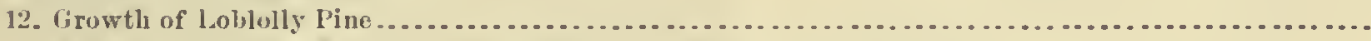

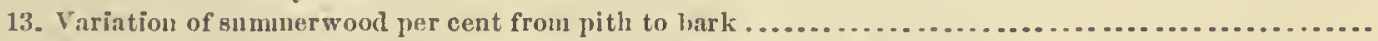

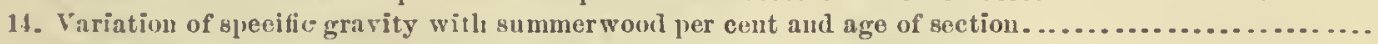

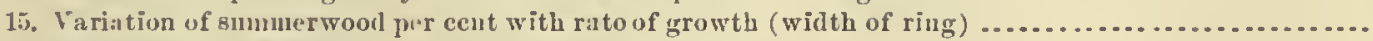

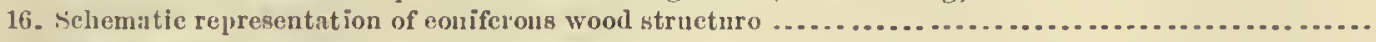

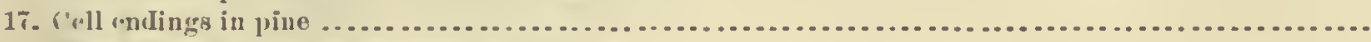

18. Cross section of normal and stunted growth. 



\title{
TIMIBER PINES OF THE SOUTHERN UNITED S'T'ATES.
}

\author{
INTRODUCTION.
}

In ignorance of the nature and withont appreciation of the economic valne of their resources, pioneers squanler and destroy withont regard to the fnture the riches they find. We have done so in the United States and are continuing to do so although the pioneering stage should have been passed, especially with onr forest resources. We have exploited them as if they were mines, instead of erops which can be larvested and reproduced contimonsly, and we liave done so in a ınost wasteful manler; nav, we have by irrational methods of exploitation, no doubt due in part to the necessities of a lapidly developing country, in many cases destroyed the conditions for natural reproduction of the more valuable timber species. Fire and indiscrininate pastnring have also assisted in the process of deterioration.

We are just beginning to realize that our timber supplies are not unlimited; that our magnificent torest resources liave been despoiled and need at least more consideration; that sooner or Iater forestry will become, nay, is now, a necessity.

Forestry is the art of producing, nitnaging, and harvesting wood crops. To be successful in this art it is of course necessary to understand the nature of the crop-to be acquainted with the life history, the conditions of development required by each species of tree composing the cropl. Such knowledge can be in part, at least, lerived from observations .uade in the natural forests, anl from these observations the manner in which the different species should be treated and rules of management may be determined.

The time for the application of forestry-that is, rational methods of treating the wood crophas not, as inany secm to suppose, come only when the natnral forest growths have been despoiled and deteriorated. On the contrary, when the ax is for the first time applied, then is the time for the application of forestry, for it is possible so to cut the original natural forest crop that it can reproduce itself in a superior manner. The judicions and systematic nse of the ax alone, in the lıands of the forester, will sccure this result.

Hence these monographs on the life history of the Southern pines liave been written primarily to cnable the owners of Southern pineries, who are now engaged ini exploiting them, to so modily . their treatment of the same as to insure continued reproduction instead of complete exhaustion, whicls is threatened nnder present methods.

The pines are the most important timber trees of the world. They attain this importance firom a combination of properties. In the first place, they possess such qualities of strength and elasticity, combined with comparatively light weiglt and ease of working, as to fit them specially for use in construction which requires the largest amonnt of wood; next, they occur as forests in the temperate zones, often to the exclusion of every other species, so that their exploitation is made easy and profitable; thirlly, they are rendily reproduced and tolerably quick growers; and, lastly, they occupy the poorest soils, prodncing valuable crops from the dry sands, and hence are of the greatest valne from the standpoint of national economy.

The Southern States abonnd in those sandy soils which are the home of the pine tribes and were once covered with seemingly boundless forests of the sane. There are still large areas untonched, yet the greater portion of the primeval forest lias not only been enlled of its best timler, but the repeated conflagrations which follow the lumbering, and, still more disastrously, the turpentine gatherers' operations lave destroyed not only the remainder of the original growth, but the vegetalle mold and the young altergrowth, leaving thousands of square miles as blackened wastes, devoid of usefinluess, and rerlucing by so unch the potential wealth of the Sonth.

There are, in general, four belts of pine forest of different ty pes recognizable, their boundaries running in general direction somew hat parallel to the coast liue: (1) The coast plain, or pine-barren flats, within the tidewater region, 10 to 30 uniles wide, once occupied mainly by the most valuable 
of Sonthern timbers, the longleaf Pine, now being replaced by C'uban and Loblolly Pines; (2) the rolling pine lills, or pine barrens proper, with a wilth of 50 to 120 miles, the true lome of the Iongleaf I'ine, which ocenpies it almost by itself; (3) the belt of mixed growth of 20 to 60 miles in width, in which the Longleaf Pine loses its predominance, the Shortleaf, the Loblolly, and the hard woods associating and disputing tertitory with it; and (4) the Shortleaf Pinc belt, where the species predominates on the sandy soils, the Longleaf being entirely absent and the Loblolly only a fcelle ennpetitor, harl wools being interspersed or ocenpying the better sites: Within the territory the species that occur ocenpy different situations. Thus the Cuban, which accompanies the Longleaf. usnally occupies the less well-nrained situations, together with the Loblolly, whish, althongh it ean aecommodate itself to all soils, reaches its best development in the rich lowlands and is specially well dereloped in the flat woods which border the coast marshes of eustern Texas, where it associates with the Shortleaf Pine it also seeks the noister situation.

The Longleaf and Shortleaf pines are, in quantity and quality eombined, the most important, while the Loblolly or Oldfield Pine, as yet not fully appreciated, comes next, ocenpying large areas. The Cuban l'ine, nsually known as Slash Pine-always cut and soll without distinction with the Longleaf P'ine-a tree of as fine rnality and of more rapid growth than the Longleaf Pine, is associated with the latter in the eoust pine belt, scattered in single individnals or gronps, but appears to increase in greater proportion in the yonng growth, being by its manner of development in early life better fitted to escipe the dangers to which the aftergrowth is exposed.

Besides these four most importaut pines, the botanical distinctions of which appear in the table below, there are a mumber of others of less signitieance. The White Pine (Pinus strobus) of the Jortl extends its reigu along the higher monutain regions of North Carolina into Georgia, forming a valuable timber tree, but of small extent. The Spruce J'ine, to which a short chapter is devoted in this Bulletin, develops into timber sizc, bnt is found mly in small quantities and mostly seattered, and has therefore as yet not received attention in lnmber markets; but its qual. ities, and especially its forestal value, being a pine whieh endures shade, will probably be appre. ciated in the future.

Since the publication of the first edition of this bulletin the Pond Pine has unexpectedly been fonnd to furnish not inconsiderable quantities of timber (sec p. 169). The Scrub Pine (1'inus virginiana) furnishes only firewood.

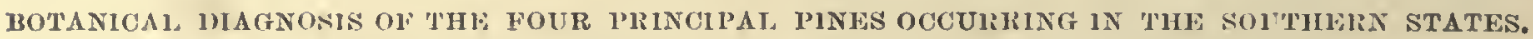

\begin{tabular}{|c|c|c|}
\hline Sjecies. & Jinus palustris Miller. & Pintes heterophylla (Fll.) Sulw: \\
\hline Leaves. . & 'Tluree in a luudle, 9 to 12 (esceptionally 14 to 15 ) incles long. & Two asul threo in a bundle: 7 to 12 (usnally 9 to 10 ) inclics \\
\hline 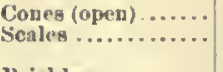 & 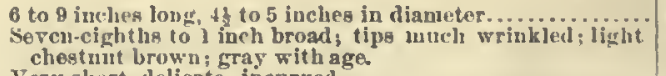 & 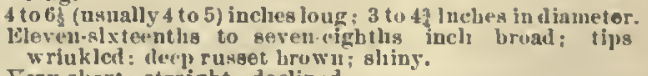 \\
\hline $\begin{array}{l}\text { l'rirkles ........ } \\
\text { Burls .......... }\end{array}$ & 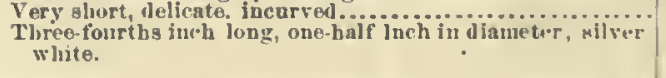 & $\begin{array}{l}\text { Very short: straight; declined. } \\
\text { A lont cutehalf inch long; one-fonrth Ineh In dianeter; } \\
\text { browuish. }\end{array}$ \\
\hline Sperleg. & Jinus echinata Miller. & Jinus toeda Linn. \\
\hline Leaves. & $\begin{array}{l}\text { Tro ind three in a bundle; } 19 \text { to } 4 \text { inclues long; commonly } \\
\text { 2f to } 4 \text { inclies. }\end{array}$ & Threo lu a bundlin; 5 to 8 inehes ling. \\
\hline Cones roper & If to 2 inclues long; 1 to 18 Inclies in dimeter............ & 23 to 4 inclies long; 19 to 3 inches in dlameter. \\
\hline Scalen .... & 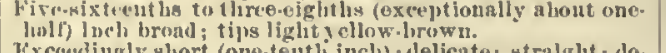 & Threo-elght ha to three-fourtho inchl broad; tips smootli; dull \\
\hline l'rickleg .. & $\begin{array}{l}\text { Kxceedingly short (ono-teuth incl)) ; deliente; stralght ; do- } \\
\text { elined. }\end{array}$ & Sliort; stout at hase. \\
\hline IHinls & 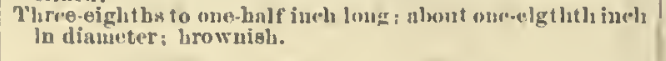 & $\begin{array}{l}\text { One-hall to three-fonrths inel, long: one-fourtli incls la di. } \\
\text { ancter; hrowuisls. }\end{array}$ \\
\hline
\end{tabular}

The greatest confusion exists with reganl to the vernacular names of these pines, in consequence of which information regarding then, given by the native popmlation, must always be carefinly scrutinized to determine exactly to what species it refers. Fren in the lumber market and anong wood consmmers, engincers, arehiteets, and carpenters the same confinsion exists; longleaf and Cuban pines are never distingnished; Shortleaf and Loblolly pines are mixel indiscriminately, and often "Sonthern Pine," or "Yellow Sonthern Pine," satisfies the specification of the architect and may come from any of the font species. 
To assist in clearing this eonfusion the following synopsis of botanieal and vernaeular names is leere inserted:

\section{NOMENCLATURE OF SOUTHERN PINES.}

\begin{tabular}{|c|c|c|c|c|}
\hline Botauicul names..... & $\begin{array}{l}\text { Pinus palustris Miller } \\
\text { Syn.: P. australis Michx. }\end{array}$ & $\begin{array}{l}\text { Pinus echinata Miller. } \\
\text { Syn.: Pinuy mitis Michx. } \\
\text { P. virginiana var. } \\
\text { echinata Du Roi. } \\
\text { P. tada rar. variabi- } \\
\text { lis Aiton. } \\
\text { P. variabilis Lamb. } \\
\text { I'. rigida Porcher. }\end{array}$ & $\begin{array}{c}\text { Pinus tada Linn. } \\
\text { Syn.: Pinus tceda var. te- } \\
\text { nuifolia Aiton. }\end{array}$ & $\begin{array}{l}\text { Pinus heterophylla (Ell.) } \\
\text { Sudw. } \\
\text { Syn. : Inus loeda var, hele } \\
\text { rophylla Ell. } \\
\text { P. ellotii Eugelm. } \\
\text { P. cubensis var. ler. } \\
\text { illocarpa Wright. }\end{array}$ \\
\hline Best common names. & LONGLEAF PINE. & SHORTLEAF PINE. & LOBLOLRY PINE. & CUBAN PINE. \\
\hline $\begin{array}{l}\text { Lucal, market, aud } \\
\text { lnmbermen's names. }\end{array}$ & 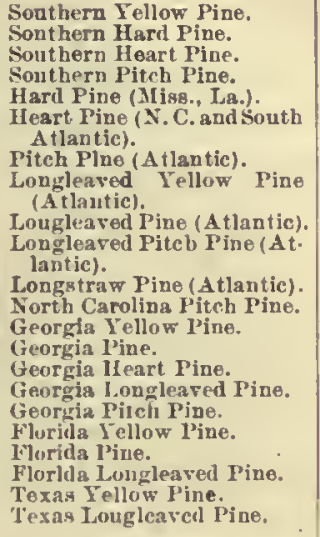 & $\begin{array}{l}\text { Yellow Pine (N. C., Ya.). } \\
\text { Shortleaved Yellow l'ine. } \\
\text { Shortleaved Pine. } \\
\text { Virginia Yellow Pine (in } \\
\text { part). } \\
\text { North Carolina Yellow Pines } \\
\text { (in part). } \\
\text { Nortl Carolina Pine (in } \\
\text { part). } \\
\text { Carolina Pine (in part). } \\
\text { slasll l'ine (N. C., Va.), in } \\
\text { part. } \\
\text { Oddfield Pine (Ala., Miss.). } \\
\text { Bull l'ine (?). } \\
\text { Spruce I'ine. } \\
\text { Rosenury Pine (X. C.). }\end{array}$ & 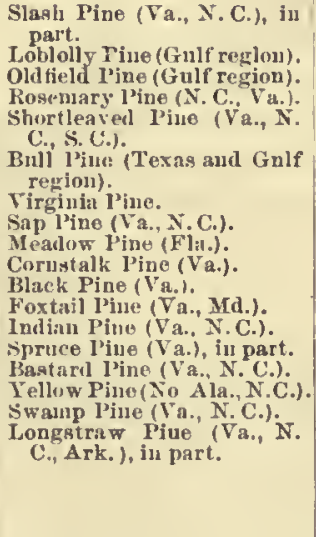 & $\begin{array}{l}\text { Slash Pine (Ga., Fla.). } \\
\text { Swamp Pine (Fla. and Ala.), } \\
\text { in part. } \\
\text { Bistard Pine (Fla., Ala.). } \\
\text { Meadow Pine (Fla., E. Miss), } \\
\text { in part. } \\
\text { Sho Pitch Pine (Ga.). }\end{array}$ \\
\hline
\end{tabular}

While it is easy enough to reeognize the speeies in the field by their botanical eharaeters, it is difienlt and often impossible to distingnish them in the wood by mere maeroscopie inspeetion or exannination with the magnifier and without the aid of the mieroseope, nor are the miscroseopie features so far reeognized suffieient for speeific distinetion.

A long-eontinued study of these woods by Mr. Filibert Roth, of the Division of Forestry, lias not developed any eharaeteristies whiell wonld be always reliable in distinguishing the speeies. The best that can be done is to give a synopsis of elaraeters, by whieh they differ generally when larger quantities, as in the log or lumber pile, are under inspeetion.

CILARACTERISTICS OF 'THF WOOD OF SOUTIERN PINES.

Diagnostic fratures of the wood.

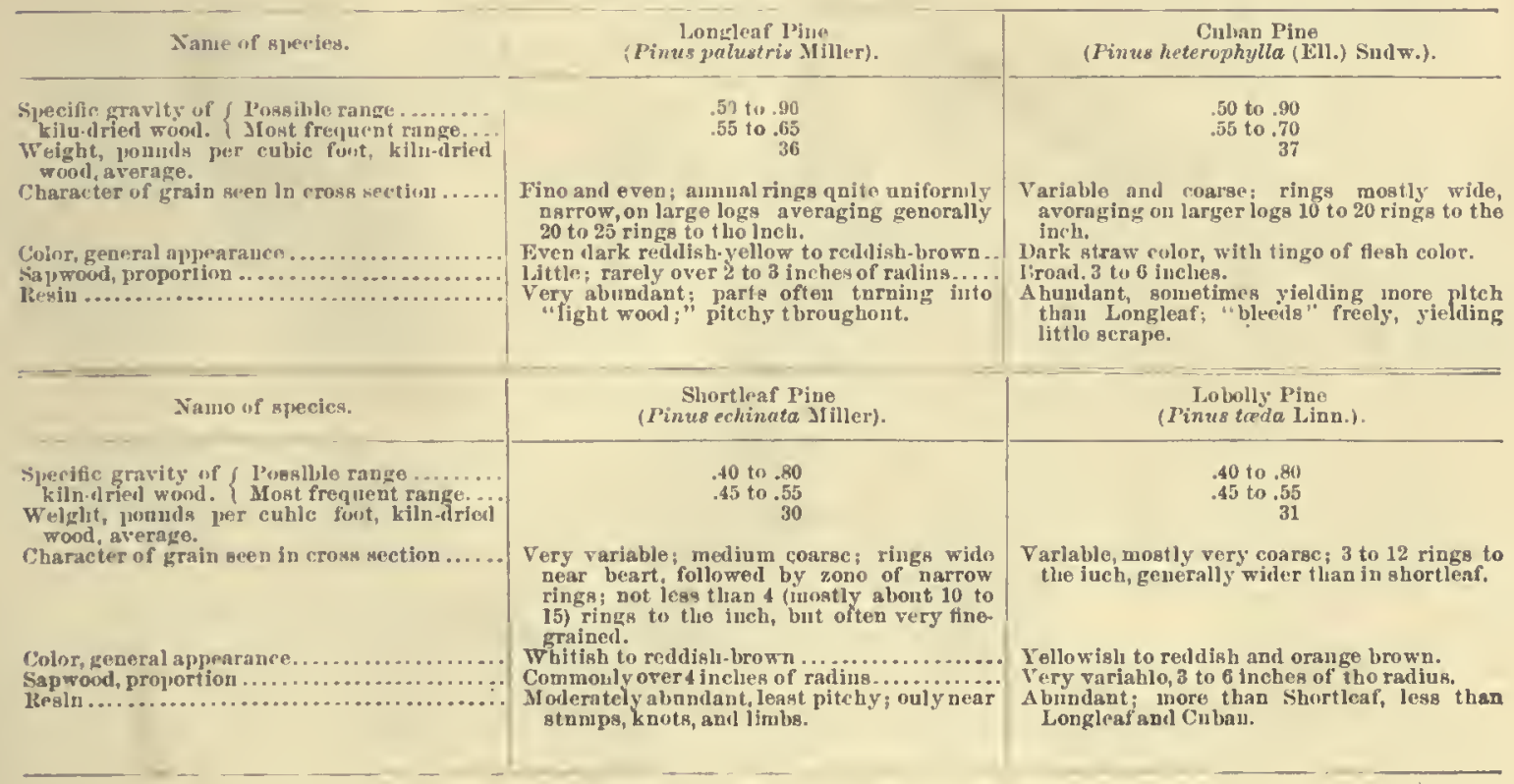


It is clear from the above diagnosis that longleaf Pine may be distinguished from Cuban Pine by its finer grain and small amount of sapwood; also that both of these differ from the Shortleaf and Ioblolly in their greater weight and the more resinons eharacter of their wool, but that the wool of the two last.ntmed speeies is rarely distinguishable beyond donlt.

'Teehnienlly the wood of the pines differs about as follows: The wool of the Jongleaf and Cuban pines are about equal in strength, Longleaf exeelling by its finer grain and smaller amonnt of sapwood. 'The same comparison may be made with regard to Loblolly and Shortleaf Pine. Being nuch nore variable, however, in weiglit and grain, exeeptions to the general rule here are very. mmerous. Of the last-named speeies it may be said that the wood derived from more sonthern localities is generally heavier and stronger than northern grown-al fact espeeially aplarent in the ease of the Shortleat Pine.

The extensive investigations carried on by the Division of Forestry luring the last three to four years mainly on these pines perunit us to give the following résumé of their mechanical properties derived from not less than 20,000 tests and as many measurenents and weighings. We quote this information from Cirenlar 12 of the division:

\section{MECHANICAL PIZOPER'IES.}

In general the wond of all these pines is heavy for pine (31 to 40 pounds per eubie foot, when dry), soft to moderately hard (hard for pine), requiring abont 1,000 pounds per square inch to indent one-twentietlı inch; stiff, the modnlus of elasticity being from 1,j00,000 upward: strong, repuniring from 7,000 ponuds per sifuare ineh and npward to break in bending and over 5,000 pounds in compression when yard-dry.

The vilnes here given are averages based on a large mumber of tests from which only defectivo pieees are exchded.

In all eases where the eontrary is not stated the weight of the wood refers to kiln-lhied material and the strength to wood eontaining 15 per eent moisture, which may be conceived as just on the border of air-dried eondition. The first table gives fairly well the range of strength of commercial timber.

Average strength of Southern Pine.

[Air.dry material (about 15 per cent noisture).]

\begin{tabular}{|c|c|c|c|c|c|c|c|c|c|c|c|c|c|c|}
\hline \multirow{4}{*}{ Name. } & \multicolumn{5}{|c|}{ Conpression strength. } & \multicolumn{7}{|c|}{ Bending strength. } & \multirow{4}{*}{ 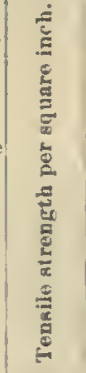 } & \multirow{4}{*}{ 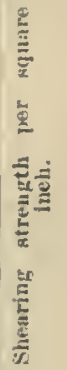 } \\
\hline & & Wilh & grain. & & \multirow{3}{*}{$\begin{array}{c}\text { Across } \\
\text { grain } \\
\text { (3 jer } \\
\text { ceut } \\
\text { indenta. } \\
\text { tion), per } \\
\text { square } \\
\text { inch. }\end{array}$} & \multicolumn{4}{|c|}{$\begin{array}{r}\text { At rupture } \\
3 \text { w? } \\
\text { modulus } 2 b h^{2}\end{array}$} & \multirow{3}{*}{$\begin{array}{c}\text { At elsstic } \\
\text { limit } \\
\text { mod wilus } \\
3 w_{1} l \\
26 h^{2} \\
\text { per square } \\
\text { inch. }\end{array}$} & \multirow{3}{*}{$\begin{array}{l}\text { Elastieits } \\
\text { (stifruess) } \\
\text { modulus } \\
3 W^{3} l^{3} \\
4 د b h^{3} \\
\text { per squaro } \\
\text { incb. }\end{array}$} & \multirow{3}{*}{$\begin{array}{l}\text { Helative } \\
\text { olastic } \\
\text { resili. } \\
\text { ence, } \\
\text { per } \\
\text { cubic } \\
\text { inch. }\end{array}$} & & \\
\hline & \multicolumn{2}{|c|}{$\begin{array}{l}\text { A verage of all } \\
\text { valid tests. }\end{array}$} & \multicolumn{2}{|c|}{$\begin{array}{c}\text { Average } \\
\text { for the weakest } \\
\text { one-tenth } \\
\text { of all the tesis. }\end{array}$} & & \multicolumn{2}{|c|}{$\begin{array}{c}\text { Average of all } \\
\text { valid tests. }\end{array}$} & \multicolumn{2}{|c|}{$\begin{array}{l}\text { Average } \\
\text { for tho werkest } \\
\text { one funth } \\
\text { of all the tests. }\end{array}$} & & & & & \\
\hline & $\begin{array}{c}\text { A banute } \\
\text { per } \\
\text { gnuare } \\
\text { incli. }\end{array}$ & $\begin{array}{l}\text { Rela. } \\
\text { tive. }\end{array}$ & $\begin{array}{c}\text { Alisolute } \\
\text { per } \\
\text { syuare } \\
\text { inch. }\end{array}$ & $\begin{array}{l}\text { Rela- } \\
\text { tive. }\end{array}$ & & $\begin{array}{l}\text { Absolute, } \\
\text { per } \\
\text { gquare } \\
\text { incli. }\end{array}$ & $\begin{array}{l}\text { Rela. } \\
\text { tive. }\end{array}$ & $\begin{array}{l}\text { Absolute. } \\
\text { per } \\
\text { squaro } \\
\text { incl. }\end{array}$ & $\begin{array}{l}\text { Rela. } \\
\text { tive. }\end{array}$ & & & & & \\
\hline $\begin{array}{l}\text { Cuban Pine.... } \\
\text { Longlear Pino.. } \\
\text { Lohlolly Pine... } \\
\text { Shortleaf I'ine.. }\end{array}$ & $\begin{array}{r}I \text { I"0unds } \\
7,850 \\
6,850 \\
6,500 \\
5,900\end{array}$ & $\begin{array}{r}100 \\
87 \\
83 \\
75\end{array}$ & $\begin{array}{r}\text { Pounde. } \\
6,500 \\
5,650 \\
5,350 \\
4,800\end{array}$ & $\begin{array}{r}100 \\
87 \\
82 \\
74\end{array}$ & $\begin{array}{r}\text { Pounds. } \\
1,050 \\
1,060 \\
990 \\
940\end{array}$ & $\begin{array}{r}\text { Pounds. } \\
11,950 \\
10,900 \\
10,100 \\
9,230\end{array}$ & $\begin{array}{r}100 \\
91 \\
84 \\
77\end{array}$ & $\begin{array}{r}\text { Pounds. } \\
8,750 \\
8,800 \\
8,100 \\
7,000\end{array}$ & $\begin{array}{r}100 \\
101 \\
92 \\
80\end{array}$ & $\begin{array}{r}\text { Pounds. } \\
0,450 \\
8.500 \\
8,150 \\
7,200\end{array}$ & $\begin{array}{l}\text { Pounds. } \\
2,305,000 \\
1,890,000 \\
1,950,010 \\
1,600,000\end{array}$ & $\begin{array}{c}\text { Pounds. } \\
2.5 \\
2.3 \\
2.25 \\
2.05 \\
2.05\end{array}$ & $\begin{array}{l}\text { L.68. } \\
14,300 \\
15,200 \\
14,400 \\
13,400\end{array}$ & $\begin{array}{r}1.6 s . \\
680 \\
706 \\
690 \\
688\end{array}$ \\
\hline
\end{tabular}

RELATION OF STRENGTH TO WHIGHT.

The intimate relation of strength and specifie weight has been well established by the experiments. The average results obtained in eonnection with the tests themselves were as follows:

\begin{tabular}{|c|c|c|c|c|}
\hline & Cuban. & 1,ongleaf. & Loblolls. & Shortleaf: \\
\hline $\begin{array}{l}\text { Transverse strength........... } \\
\text { Specife weight of test pleces.. }\end{array}$ & $\begin{array}{l}100 \\
100\end{array}$ & 91 & $\begin{array}{l}84 \\
82\end{array}$ & 77 \\
\hline
\end{tabular}


Since, in the determination of the specitie gravity above givell, wood of the same per eent of moisture (as is the case in the values of strength) was not always involved, and also sinee the test pieces, owing to size and shape, ean not perfectly represent the wood of the entire stem, the following results of a speeial inquiry into the weight of the wood represents probably more aecurately the weight and with it the strength relations of the four speeies.

\section{WEIGIIT RELA'TIONS.}

[These data refer to the average specitie weight for all the wool of each tree, only trees of approximately the rance age lioing involvel.]

\begin{tabular}{|c|c|c|c|c|}
\hline & Cuban. & Iongleaf. & I.oblolly. & Shortleaf. \\
\hline 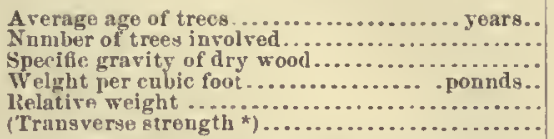 & $\begin{array}{l}171 \\
6 \\
0.63 \\
39 \\
100 \\
(100)\end{array}$ & $\begin{array}{l}127 \\
22 \\
0.61 \\
38 \\
97 \\
(91)\end{array}$ & $\begin{array}{l}137 \\
14 \\
0.53 \\
33 \\
84 \\
(84)\end{array}$ & $\begin{array}{l}131 \\
10 \\
0.51 \\
32 \\
81 \\
(77)\end{array}$ \\
\hline
\end{tabular}

* The valnes of stringth refer to all tests, and tberefore involve trees of wide range of age and consequently of quality, especially those of Longleaf; involve inucli woorl of old trees, hence the relation of welgbt and strength appears less distinct.

From these results, altlough slightly at variance, we are justified in eoneluding that Cuban and Longleat Pine are nearly alike in strength and weight and excel Loblolly and Shortleaf by about 20 per cent. Of these latter, contrary to common belief, the Loblolly is the heavier and stronger.

The weakest material would differ ftom the average material in transverse strengtlı by about 20 per cent, and in eompression strength by about 30 to 35 per cent, except Cuban Pine, for which the difference appears greater in transverse and smaller in compression strength. It must, of eonrse, not be overlooked that these figures are obtained from full-grown trees of the virgin forest, that strength varies with physical conditions of the material, and that therefore an intcligent inspection of the stick is always necessary before applying the values in practice. They ean only represent the averagc conditions for a large amount of material.

DISTRIIIIION ON WEIGHT AND STRENGTII TIROUGHOUT TIE TREE.

Weight and strength of wood at different heights in the tree.

\begin{tabular}{|c|c|c|c|c|c|c|c|}
\hline & \multicolumn{2}{|c|}{$\begin{array}{l}\text { Strength of Longleaf } \\
\text { Plng (ponnis iver } \\
\text { square incb). }\end{array}$} & \multicolumn{3}{|c|}{ Specifie weight. } & \multirow{2}{*}{$\begin{array}{l}\text { Mean of all } \\
\text { three } \\
\text { species } \\
\text { (relative } \\
\text { weight). }\end{array}$} & \multirow{2}{*}{$\begin{array}{l}\text { Relative } \\
\text { sirength of } \\
\text { I.ungleaf } \\
\text { Pino (mean } \\
\text { of com. } \\
\text { pression } \\
\text { and } \\
\text { bending). }\end{array}$} \\
\hline & $\begin{array}{l}\text { Bending } \\
\text { strengtli. }\end{array}$ & $\begin{array}{l}\text { Compres- } \\
\text { sion } \\
\text { ondwiso } \\
\text { (with } \\
\text { grain). }\end{array}$ & Longleaf. & Loblolly. & Shortleaf. & & \\
\hline $\begin{array}{l}\text { Ninmber trees nsed......... } \\
\text { A verage age of trees....... }\end{array}$ & \multicolumn{2}{|c|}{$\begin{array}{c}56 \\
150 \text { (over) }\end{array}$} & $\begin{array}{r}22 \\
127\end{array}$ & $\begin{array}{r}14 \\
113\end{array}$ & $\begin{array}{r}12 \\
131\end{array}$ & 48 & 50 \\
\hline \multicolumn{8}{|l|}{$\begin{array}{r}\text { Number of feet from stump: } \\
0 \ldots \ldots\end{array}$} \\
\hline $6 \ldots .$. & 12,100 & 7,350 & .705 & .595 & .585 & & \\
\hline $10 \ldots$ & 11,650 & 7,200 & .074 & .578 & $\begin{array}{r}100 \\
.565\end{array}$ & ton & 100 \\
\hline & $\begin{array}{r}96 \\
10.700\end{array}$ & 38 & 96 & $\begin{array}{r}37 \\
534\end{array}$ & 97 & $3 \pi$ & 97 \\
\hline 20. & $\begin{array}{r}10,700 \\
89\end{array}$ & $\begin{array}{r}6,800 \\
98\end{array}$ & .624 & .534 & .523 & $m$ & 20 \\
\hline $30 \ldots$ & $\begin{array}{r}10,100 \\
84\end{array}$ & $\begin{array}{r}6,500 \\
83\end{array}$ & .590 & $\begin{array}{r}.508 \\
86\end{array}$ & .496 & 85 & 86 \\
\hline $40 \ldots$ & 0,500 & 6,300 & .560 & .491 & .472 & & \\
\hline $50 \ldots$. & 9,000 & $\begin{array}{r}86 \\
6,150\end{array}$ & $\begin{array}{r}80 \\
.539\end{array}$ & $\begin{array}{r}8 S \\
.470\end{array}$ & $\begin{array}{r}81 \\
.455\end{array}$ & 81 & 82 \\
\hline $60 \ldots$. & 8,600 & $\begin{array}{r}88 \\
6,050\end{array}$ & $\begin{array}{r}77 \\
.528\end{array}$ & $\begin{array}{r}80 \\
.470\end{array}$ & $\begin{array}{r}78 \\
.454\end{array}$ & 78 & 79 \\
\hline & 71 & $8 \%$ & 75 & 79 & 78 & 77 & 26 \\
\hline
\end{tabular}

Note. - Relative values are indicated by italic figures. 
In any one tree the wood is lighter and weaker as we pass from the base to the top. 'This is trice of every treo mul of all fonr speeies. The decrease in weight and strength is most pronouneed in tho first 20 feet from the stunp) and grows smaller upwart. (See fig. 1.)

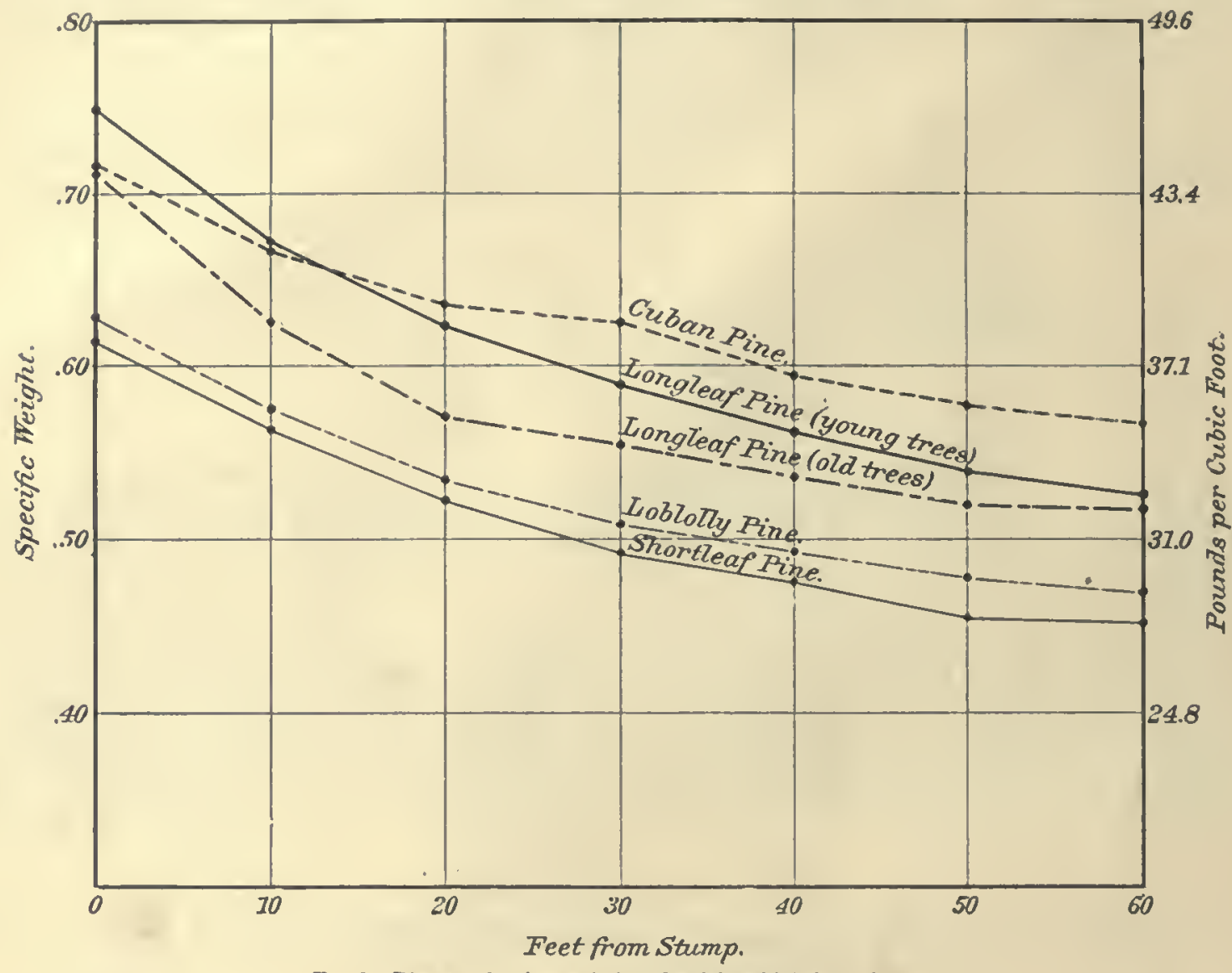

FIG, 1.-Diagram showing variation of weight with height of tres.

This great difference in weight and strength between butt and top finds explanation in the relative width of the summerwood. Sinee the specific weight of the dark summerwood band in ench ring is in thrifty growth from 0.90 to 1 , while that of the springwood is only about 0.40 , the relative anomnt of summerwood furnishes altogether the most delieate and acenrate measure of these differences of weight as well as strength, and hence is the su rest eriterion for ocular inspeetion of quality, especially sinee this relation is free from the disturbing influence of both resin and moisture contents of the wood, so eonspieuous in weight determinations.

The following fignres show the distribution of the summerwood in a xingle tree of Longleaf Pine, as an example of this relation:

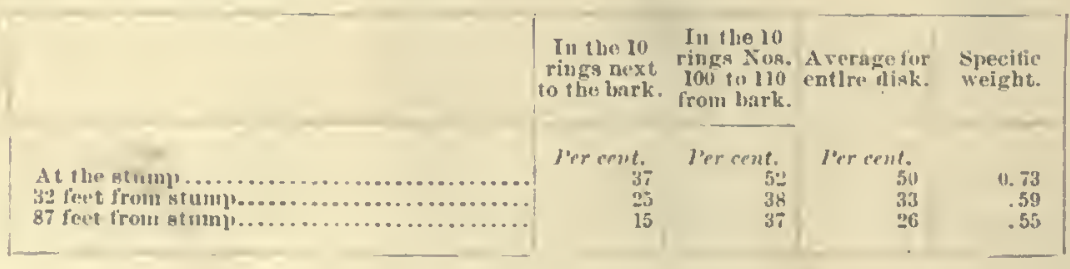


Logs from the top ean usually be reeognized by the larger pereentage of salpwood and the smaller proportion and more regular ontlines of the bands of summerwood, which are more or less wavy in the butt logs.

Both weight and strength vary in the different parts of the same cross seetion from eenter to periphery, and though the variations appenr frequently irregular in sh̆hgle iudividnals, a definite law of relation is nevertheless discernible in large averages, and onee determined is readily observable in every tree.

A separate inquiry, avoiding the many variables which enter into the meehanieal tests, permits the following deduetions for the wood of these pines, and espeeially for Longleaf; the data referring to weight, but by inference also to streugth:

1. The variation is greatest in the butt $\log$ (the heaviest part) and least in the top logs.

2. The variation in weight, henee also in strength, from eenter to periphery depends on the rate of growth, the heavier, stronger woor being formed during the period of most rapid growth, lighter and weaker wood in old age.

3. Aberiations from the normal growth, due to unusual seasons and other disturbing eanses, cloud the miformity of the law of variation, thus oecasion. ally leading to the formatiou of heavier, broad-ringed wood in old, and lighter narrow-ringed wood in young trees.

4. Slow-growing trees (with narrow rings) do not make less heavy, nol heavier wood than thriftily grown trees (with wide rings) of the same age. (See fig. 2.)

\section{EFFECT OF AGE.}

The interior of the butt log, representing the young sapling of less than fifteen or twenty year's of age, and the central portion of all logs eontaining the pith and two to five rings adjoining, is always light and weak.

The heaviest wood in Longleaf and Cuban Pine is formen between the ages of fifteen and one hundred and twenty years, with a specifie weight of over 0.60 and a maximnm of 0.66 to 0.98 , between the ages of forty and sixty years. The wood formed at the age of about one liundred years will hare a speeifie weight of 0.62 to 0.63 , whieh is also the average weight for the entire wood of old trees; the wood formed after this age is lighter but does not fall below 0.50 up to the two hundredth year; the strength varies in the sane ratio.

In the shorter-lived Loblolly and Shortleaf the perior for the formation of the heaviest rood is

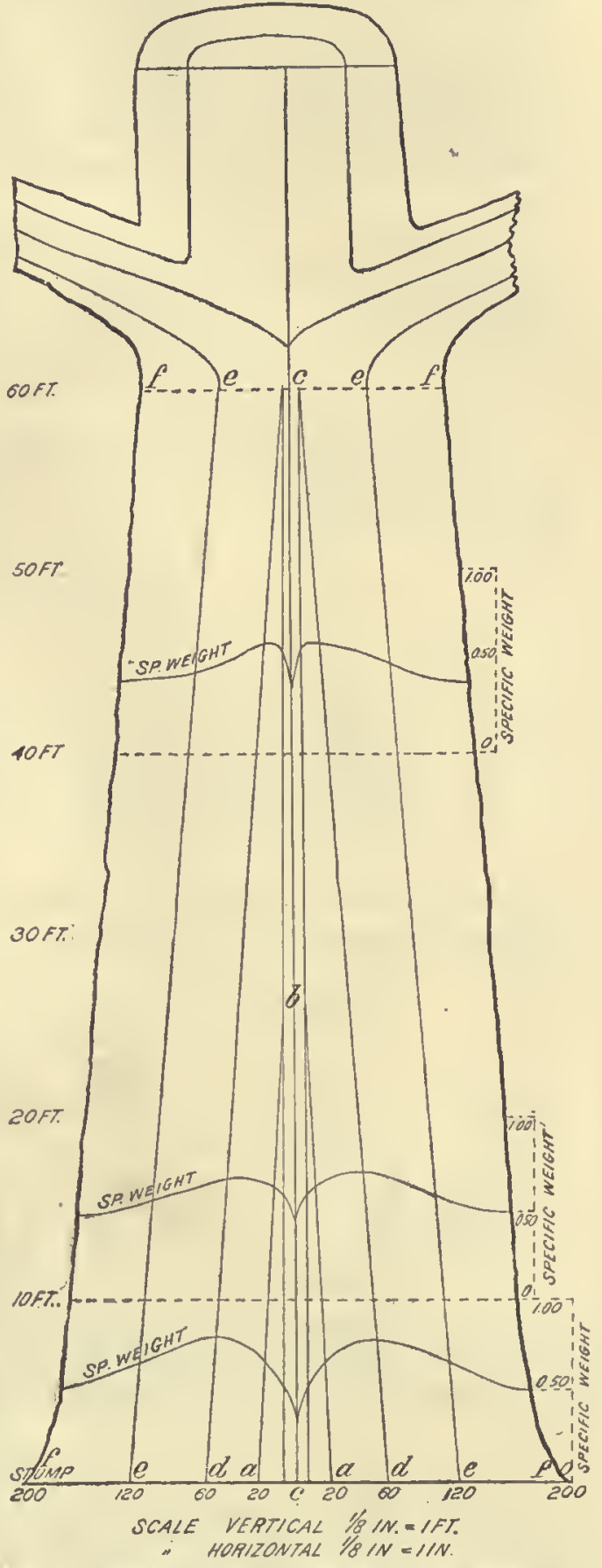

Fra. 2.-Schematic section through stem of Longleaf Pine, showing variation of specific weight with hoight, diameter, and ago at twenty $(a b a)$, sixty $(d c d)$, oue hundred and twenty (eeee), and two hnndred (ffff) years.

between the ages of fifteen and eighty, the average weight being then over 0.50 , with a maximum of 0.57 at the age of thirty to forty. The average weight for old trees (0.51 to 0.52$)$ lios about the seventy-fifth year, the weight then falling off to abont 0.45 at the age of one hundred aud forty, and continuing to deerease to below 0.38 , as the trees grow older.

7092-No. $13-2$ 
That these statements refer only to the clear portions of eaeh log, and are variably affected at each whorl of knots (every 10 to 30 inches) aecording to their size, and also by the variable auounts of resin (n) to 20 per eent of the dry weight), must be self-erident.

Silpwood is not necessarily weaker than heartwood, ouly nsually the sapwood of the largesi\%ed trees we are now using is represented by the narrow-ringed onter part, which was formed dnring the old-age period of growth, when naturally lighter and wealier wood is male; but the wool formed during the more thrifty diameter growth of the first eighty to oue humblreal year: sapwood at the time, changel into heartwood later-was even as sapwood the heaviest and strongest.

\section{IRANGE OF VALUES FOR WEIGHT AND STRENGTH.}

Althongh the range of values for the individual tree of any given speeies varies from bntt to top, and from center to periphery by 15 to 25 per eent, and occusionally more, the deviaţion from average values from one individual to another is not usually as great as has been believerl; thus, of 56 trees of Isongleaf Pine, 42 trees varied in their averige strength by less than 10 per cent from the average of all 56.

The following table of weight (which is a direet and fair indieation of strength), representing all the wood of the stem and excluding knots and other defeets, gives a more perfect idea of the range of these values:

Range of specific weight with age (kiln-dried wood).

['o avold fractions the values are multiplied by 100.]

\begin{tabular}{|c|c|c|c|c|}
\hline & Cuban. & Longleaf. & Loblolly. & Shortleaf. \\
\hline Number of trees involved.............. & 24 & 96 & 60 & 56 \\
\hline Trees over $t$ wo hundreil years old............. & 61 & 57 & & 0 \\
\hline Trees one liundred and fity to two hundred years old... & 63 & 59 & 50 & \\
\hline Trees one hundred to one himblred and fifty years old... & & 60.5 & 53 & 51 \\
\hline Trees fifty to one hundred years old.............. & 61 & 62 & 53.4 & 55 \\
\hline Treess twenty-five to fifty years old...................... & 55 & 61 & 53.3 & 57 \\
\hline 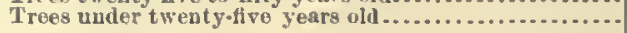 & 51 & 55 & 48 & 53 \\
\hline
\end{tabular}

Thougl oceasionally sone very exeeptional trees ocenr, espeeially in Loblolly and shortleaf, the range on the whole is generally within remarkably narrow lumits, as appears from the following table:

Range of specifio weight in trees of the same age approximately; averages for whole trees.

[Specifie gravity multiplied by 100 to avoid fractions.]

\begin{tabular}{|c|c|c|c|c|c|c|c|c|c|c|c|c|c|c|c|c|}
\hline Nane. & $\begin{array}{l}\text { Number } \\
\text { of trees. }\end{array}$ & $\begin{array}{l}\text { A ge, } \\
\text { yegrs. }\end{array}$ & \multicolumn{13}{|c|}{ Single trees. } & A verage. \\
\hline 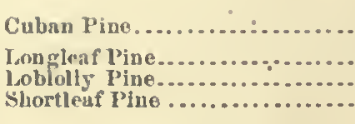 & $\left\{\begin{array}{r}4 \\
5 \\
13 \\
10 \\
12\end{array}\right.$ & $\begin{array}{r}150-200 \\
50-100 \\
100-150 \\
125-150 \\
100-150\end{array}$ & $\begin{array}{l}56 \\
60 \\
59 \\
51 \\
45\end{array}$ & $\begin{array}{l}68 \\
58 \\
66 \\
51 \\
47\end{array}$ & $\begin{array}{l}62 \\
60 \\
57 \\
53 \\
53\end{array}$ & $\begin{array}{l}65 \\
59 \\
62 \\
51 \\
47\end{array}$ & $\begin{array}{l}67 \\
67 \\
66 \\
55 \\
50\end{array}$ & $\begin{array}{l}58 \\
58.3 \\
51\end{array}$ & $\begin{array}{l}50 \\
54 \\
55\end{array}$ & $\begin{array}{l}57 \\
55 \\
5 ;\end{array}$ & $\begin{array}{l}57 \\
55 \\
53\end{array}$ & $\begin{array}{l}66 \\
52 \\
51\end{array}$ & \begin{tabular}{|c|}
59 \\
50
\end{tabular} & 62 & $\begin{array}{c}57 \\
\cdots \\
\cdots\end{array}$ & $\begin{array}{l}62.5 \\
60.9 \\
60.5 \\
52.8 \\
50.8\end{array}$ \\
\hline
\end{tabular}

From this table it wonld appear that single iudividuals of one species would approximate single individuals of another species so elosely that the weiglit distinction seems to fitil, hnt in large numbers, for instance carloads of material, the averages above given will prevail.

\section{INFLUENCE OF LOCALITY.}

In both the Cuban and Longleaf Pine the locality where grown appears to have lut little influenee on weight or strength, and there is no reason to believe that the Longleaf l'ine from one State is better than that from any other, since sneh variations as aro dainerl an be found on any 40-acre lot of timber in any State. But with Loblolly, and still more with Shortleat, this ner.ms not to be the ease. Being widely distributerl over many localities dlfferent in soil and climate, the grow th of the Shortleaf Pine seems materially influencerl by lowitin. The wool from the Sontlieru Ooast and Gulf region and even Arkansas is generally heavien than the wood from localities further north. Very light and fine-grained wood is seldom met urar the sontbern linit of the lange, while it is almost the rule in Missonri, where forms resembling the Norway Pine are by no menus rare. The Loblolly, oceupying both wet aud dry soils, varies accordiugly. 


\section{INFLUEYCE OF MOISTURE.}

This influenee is among the most important, henee all tests have been made with dne regard to moisture contents. Seasoned wood is stronger than green and moist wood; the difference between green and seisoned wood may amonnt to 50 and even 100 per cent. The influence of seasoning consists in (1) bringing by means of slırinkage about 10 per cent more fibers into the same square inch of cross section than are contained in the wet wood; (2) shrinking the cell wall itself by about 50 per cent of its eross section and thns hardening it, just as a cowskin becomes thimer and harder by drying.

In the following tables and diagram this is fully illustrated; the values presented in these tables and diagrans are bised on large nnmbers of tests and are fairly safe for ordinary use. They still require further revision, since the relations to density, etc., have had to be neglected in this study.

Influence of moisture on strength.

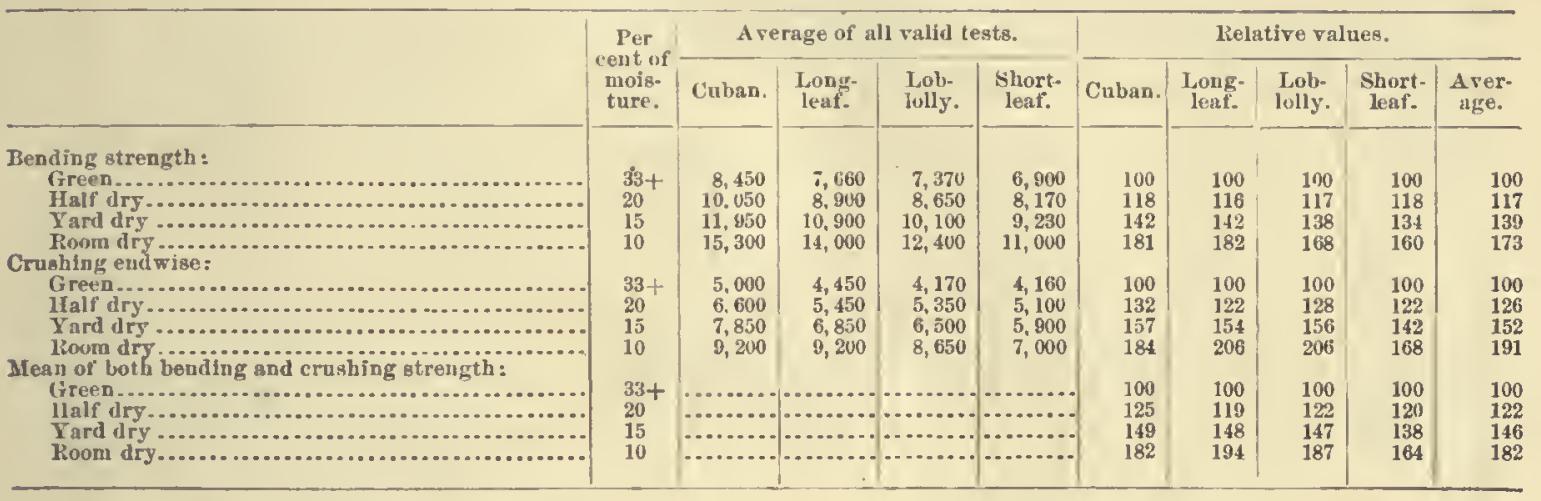

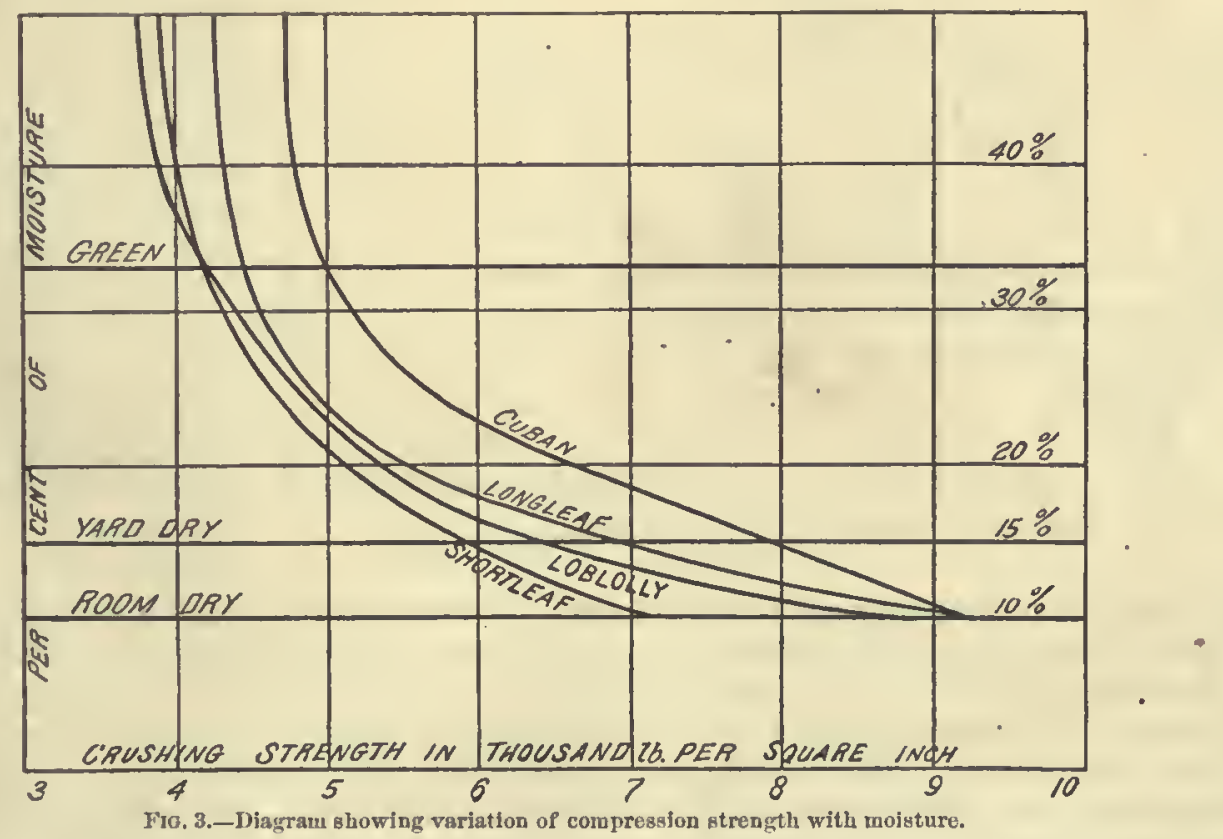

It will be observed that the strength inereases by about 50 per cent in ordinary good yard seasoning, and that it ean be increased abont 30 per eent nore by complete seasoning in kiln or house.

Large timbers refuire several years before even the yard-seasoned eondition is attained, but 2.inch and lighter material is generally not used with more than 15 per eent of moisture. 


\section{WEIGHT AND MOISTURE.}

So far the weight of only the kiln-dry wood has been eonsidered. In fresh as well as all yard and air dried material there is eontained a variable anount of water. The amount of water containel in fresh wood of these pines forms more than half the weiglit of the fresh salpwood, and about one-fiftl to one-fourtl of the heartwood. In yard-dry wool it fulls to abont 1: to 18 per cent, while in wood kept in well-ventilated, and espeeially in lieated rooms it is abont jo to l1) per eent, varying with size of pieee, part of tree, speeies, temperature, and lumidity of ail. Heatel to $1500^{\circ} \mathrm{F} .\left(65^{\circ} \mathrm{C}\right.$.), the wood loses all but abont $1 \frac{1}{2}$ to 2 per cent of its moisture, and if the temperature is raised to $175^{\circ} \mathrm{F}$. there remains less than 1 per cent, the wood dried at $212 \circ \mathrm{F}$. being assumed to be (though it is not really) perfeetly dry. Of eonrse, large pieces are in practice never left long enough exposed to beeome truly kiln dry, though in fartories this state is often approachel.

As long as the water in the wrood amounts to about 30 per eent or more of the diry weight of the wood there is no shrinkage ${ }^{1}$ (the water eoming from the eell lunen, and the density or specific gravity elunges simply in direet proportion to the loss of water. When the moisture per eent falls below about 30 , the water eomes from the eell wall, and the loss of water and weight is aceun-

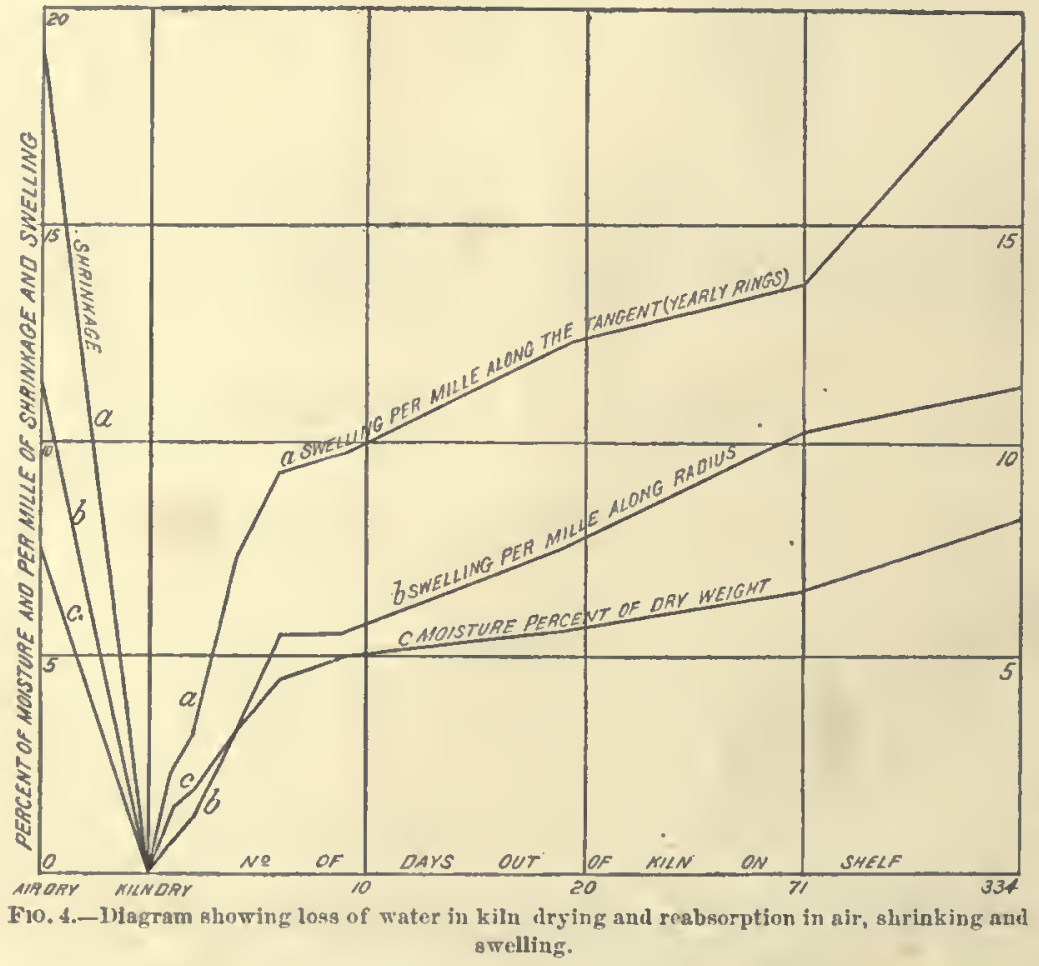
pauied by a loss of volume, so that both faetors of the finetion

$$
\text { Speeific gravity }=\frac{\text { weight }}{\text { volume }}
$$

are affected, and the change in the speeific gravity no longer is simply proportional to the loss of water or weight. The loss of weight and vol. une, lowerer, being mequal and disproportionate, anarked reduction of the speeifie gravity takes place, amounting in these pines to about 8 to 10 per eent of the speeifie weight of the dry wood.

\section{SHRINKAGE.}

The behavior of the wood of the Southern pines in shrinkage does not differ materially. Generally the heavier wood slirinks the most, and sapwood slrinlis a bout one-fourth more than heartwood of the same speeifie weight. Very resinous pieces ("light wood") shrink mueh less than other wood. In keeping with these general faets, the shrinkage of the wood of the upper $\operatorname{logs}$ is usually 15 to 20 per eent less than that of the butt pieces and the shrinkage of the heary heartwood of old trees is greater than that of the lighter peripheral parts of the same, while the shrinkage of the heavy wool of saplings is greatest of all. On the whole, the wood of these pines slurinks about 10 per cent in its volune -3 to 4 per eent along the radius, and 6 to 7 per cent along the tangent or aloug the yearly rings.

After leaving the kiln the wood at once begins to absorb moisture and to swell. In an experiment with short pieees of loblolly and shortleaf, representing orlinary flooring or siding

"In ordinary lumber and all large size naterial the extorior parts commonly dry so much sooner than the lulk of the stick that checking often occurs though the moisture per cent of the whole stick is still far above 30 . 
sizes, these regained more than half the water and underwent over half the total swelling during the first ten days after leaving the kiln (see fig. 4). Even in this less than air-dry wood the clanges in weight far excel the changes in volume (sum of radial and tangential swelling), and, therefore, the specific gravity even at this low per cent of moisture was decreased by drying and increased by snbscquent absorption of moisture. Immersion and, still more reallily, boiling cause the wood to return to its original size, but temperatmes even above the boiling point do not prevent the wood from "working," or shrinking and swelling.

In fig. $t$ are represented the results of experiments on the rate of loss of water in the dry kiln and the reabsorption of water in the air. The wood used was of Loblolly and Shortleaf Pine kept on a shelf iu an ordinary room before and after kiln drying. The measurements were made with caliper.

\section{EFFEC' OF "BOXING," OR "BI,EEDING."}

"Bleeding" pine trees for their resin, to which chiefly Longleaf and (juban Pine are snbjected, has generally been regarded as injurious to the timber. Both dnrability and strength, it was claimed, were impaired by this process, and in the specifications of many architects and large consumers, such as railway companies, "bled" timber was excluded. Since the utilization of resin is one of the leading industries of the Sonth, and since the process affects several millious of dollars' worth of timber every year, a special investigation involving mechanical tests, physical and chemical analyses of the wood of bled and unbled trees from the same locality were carrich out by this division. The results prove conclusively (1) that bled timber is as strong as unbled if of the same weight; (2) that the weight and shrinkage of the wood is not affected by bleeding; (3) that bled trees contain practically neither more nor less resin than unbled trees, the loss of resin referriug only to the sapwood, and therefore the dnrability is not affected by the bleeding process.

The following table shows the remarkable numerical similarity between the average results for three groups of trees, the higher valnes of the bled material being readily explained by the difference in weight:

\begin{tabular}{|c|c|c|c|c|}
\hline Longleaf Pine. & $\begin{array}{c}\text { Nnmber of } \\
\text { tests. }\end{array}$ & $\begin{array}{l}\text { Specific } \\
\text { weight of } \\
\text { test pieces. }\end{array}$ & $\begin{array}{l}\text { Bending } \\
\text { strengtl } \\
\text { per square } \\
\text { inch. }\end{array}$ & $\begin{array}{l}\text { Compression } \\
\text { strength } \\
\text { per square } \\
\text { inch. }\end{array}$ \\
\hline 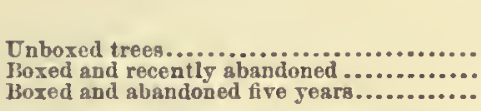 & $\begin{array}{l}400 \\
390 \\
535\end{array}$ & $\begin{array}{r}\text { Per ccnt. } \\
0.74 \\
.79 \\
.76\end{array}$ & $\begin{array}{r}\text { I'ounds. } \\
12,358 \\
12,961 \\
12,586\end{array}$ & $\begin{array}{r}\text { Pounds. } \\
7,166 \\
7,813 \\
7,575\end{array}$ \\
\hline
\end{tabular}

The amount of resin in the wood varies greatly, and trees growing side by side differ within very wide limits. Sapwood contains but Iittle resin ( 1 to 4 per cent), even in those trees in which the heartwood contains abundance. In the heartwood the resin forms from 5 to 24 per cent of the dry weight (of which about one-sixtl is turpentine), and can not be removed by bleeding, so that its quantity remains unaffected by the process.

Bled timber, then, is as usefnl for all purposes as unbled.

\section{USE OF TIIE WOOD.}

In its use the wood of all fonr species is much alike. The coarse-grained, heavy, resinons forms are especially suited for timbers and dimension stuff; while the fine-grained wood, whatever species it may belong to, is used for a great variety of purposes.

At present distinction is but rarcly made in the species and in their use; all four species are used mnch alike, althongh differentiation is very desirable on acronnt of the difference in quality. Formerly these pines, except for local use, were mostly cut or hewn into timbers, but especially since the use of dry kilns has become general and the simple oil finish has displaced the unsightly painting and "graining" of wood, Southern pine is ent into every form and grade of lunber. Nevertheless, a large proportion of the total cut is still being saved to order in sizes above 6 by 6 inches and lengths above 20 feet for timbers, for which the Longleaf and Cnban Pine furnish ideal material. The resinons condition of these two pines make them also desirable for railway ties of lasting quality. 
Since the enstom of painting and graining woodwork has given way to natural grain with oil finish, the wood of these hard pines is becoming very popular for inside finish.

Kiln-drying is sneeessfinlly practiced with all four spceies, but espeeially with the Shortleaf and Loblolly pines whieh, if not artifieially sensoned, are liable to "blue." The wood ean be dried without great injury at high temperatures.

\section{RATE OF GROWTH.}

The speeies natmally develop somewhat differently, aeeording to the soil eonditions in whieh they ocenr. Without going into a detailed disenssion, whieh will be found in the body of this work under enel species, in comparison of the rate of growtl of the four speeies, based on a large number of measurements, gave, for average trees and average conditions, the results shown in the aecompanying diagrams (figs. 5 to 7 ), whieh permit the determination of the rate of growth at different periods of their life.

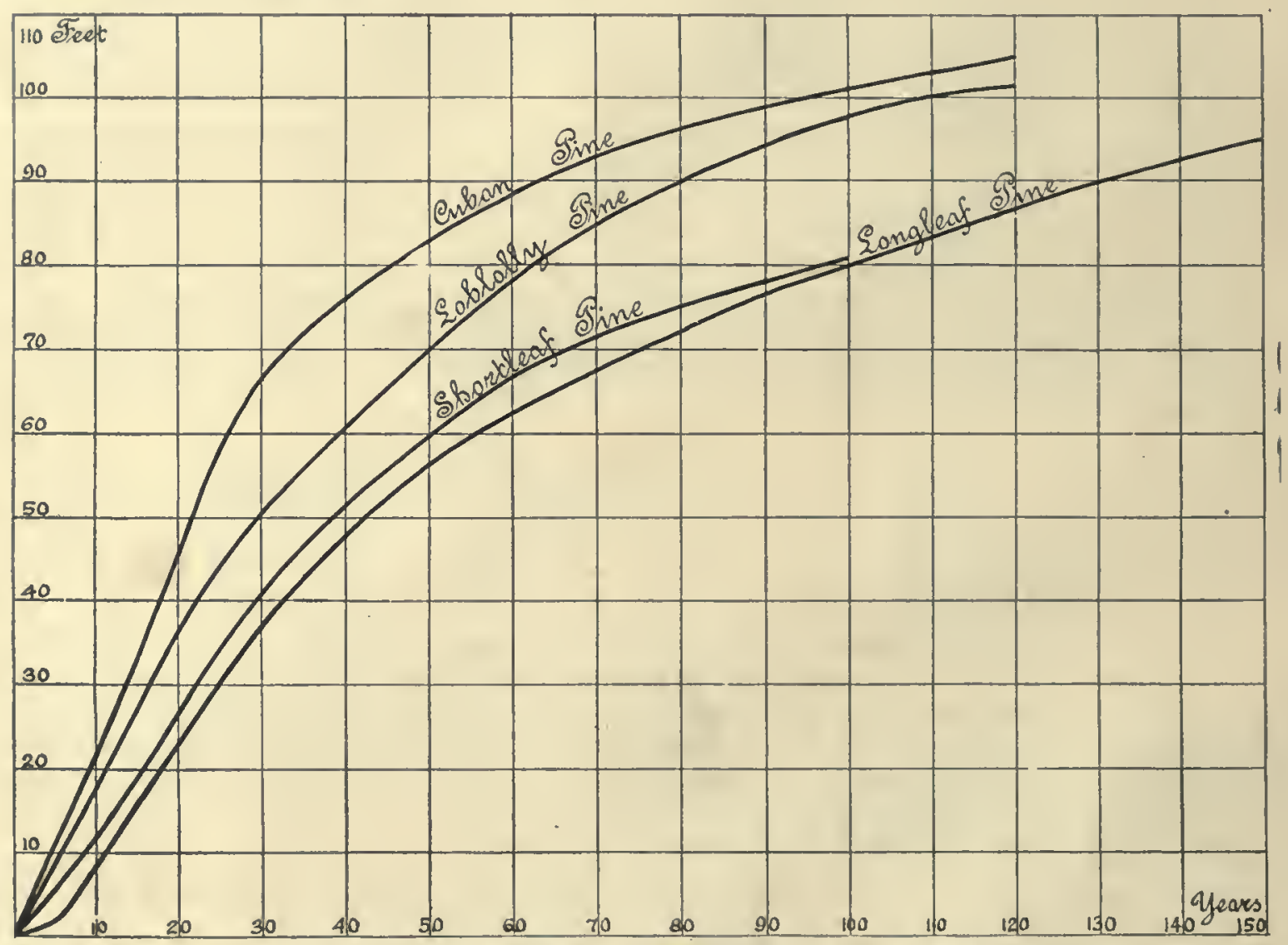

Fia. 5.-Diagram showing comparative progress of height growth in average frees.

From these it appears that the Cuban Pine is by far the most rapirl grower, while the Iongleaf Pine, which usually grows assoeiated with the former, is the slowest, Loblolly and Shortleaf oeenpying a position between the two.

The Longleaf shows for the first five to seven years hardly any levelopment in height and begins then to grow rapidly and evenly to the fiftietl or seventieth year, and even after that period, though the rate is somewhat diminished, progresses evenly and steadily, giving to the height enrve a smooth and persistent charaeter.

The diameter growth shows the same even and persistent progress from the start, and the volume growth also progresses eveuly after the rapid height growth rate is passed at seventy years.

The Cuban l'ine ceases in its maximum rate of height growth at thirty years, starts with its diameter growth at about the rate of the Loblolly, but after the twenty.fifth year leaves the latter 
behind for the next twenty-five to thirty years, then proeeeds at about the same rate, but persisting longer than the Loblolly. At the age of tifty years the Cuban Pine with 46 cubie feet has made nearly twice the amonnt of the Loblolly and more than fonr times that of the Longleaf, bnt at one hundred years the differenee is redueed, being then 115, 90, and 55 eubie feet, respectively, for the three speeies.

Both Loblolly and Shortleaf Pine reach their maximum growth sooner than the other two speeies. While these still show a persistently ascending line at one luundred and twenty to one hundred and forty years, the rate of growth in the Loblolly shows a deeline after the one liundredth year, and the Shortleaf has done its best by the eiglitieth year. These faets give indications as to the rotation under which these various species may be managed.

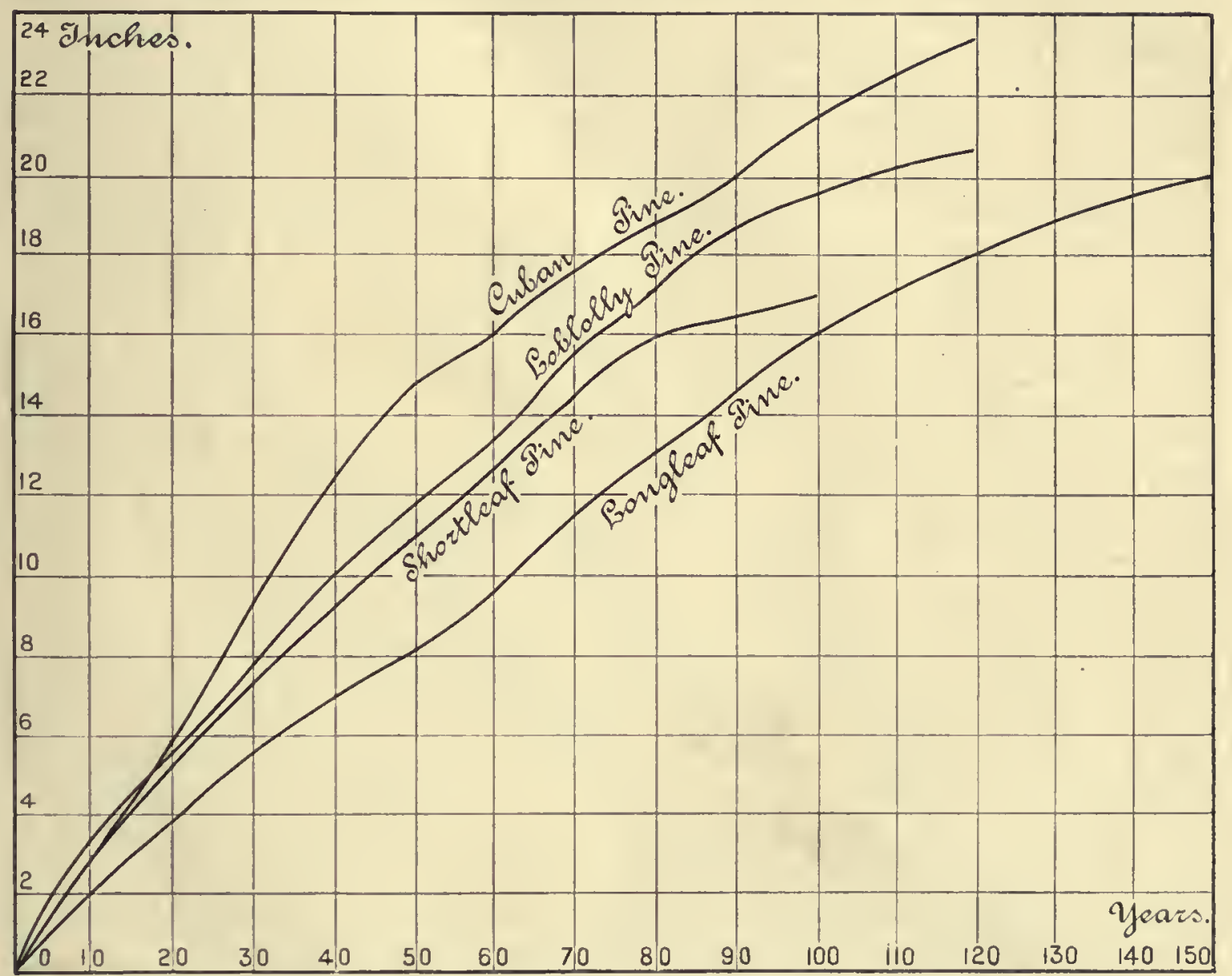

Fin. 6.-Dingram showing enmparative progress of diameter growth in averago trees.

As staterl before, the growtlı of trees, especially in the virgin forest, is quite variable even for the same species and same soil eonditions; an average, therefore, like the one presented in the diagrans, however perfect, eould apply only when large numbers are eonsidered. Thus there are fast-growing trees of Longleaf and slow-growing of Cnban or Loblolly Pine. Yet the diagrams will fairly well represent the average growth, with the possible exeeption of the Cuban Pine, for whieh the number of measurements was too small to furnish reliable data.

\section{STATISTIES AND CONCLUSIONS.}

The greatest difficulty 1). Mohr has fonnd is in the statistieal portions of his work. To deternine the annonuts of renaining timber supplies of the varions speeies is almost an impossibility withont a very elaborate and laborious canvass, which, to be sure, it wonk appear our dnty to 
undertake, but for which the means at the disposal of the Division of Forestry have never been suffieient. Even the anomit of annual consumption can only be approximated, partly becanse the species are not always kept separate and partiy beeause information is not always readily given by the operators or shippers.

The statistics for Longleaf Pine ean be more nearly approximater, for the majority of the mills engaged in its exploitation eut hardly any other timber; moreover, its geographical limits are more elearly defined, so that even the area of remaining supplies is not eutirely beyond our ken.

When it comes to nsing such statistics for a proguostication as regards available snpplies, another difficulty arises in the change of standards of material recognized as marketable and the ehange of demand or use, and hence consumption, of any of the rarieties. But we can now safely assume that the standard of size and quality, which was high when the census figures of 1880 were

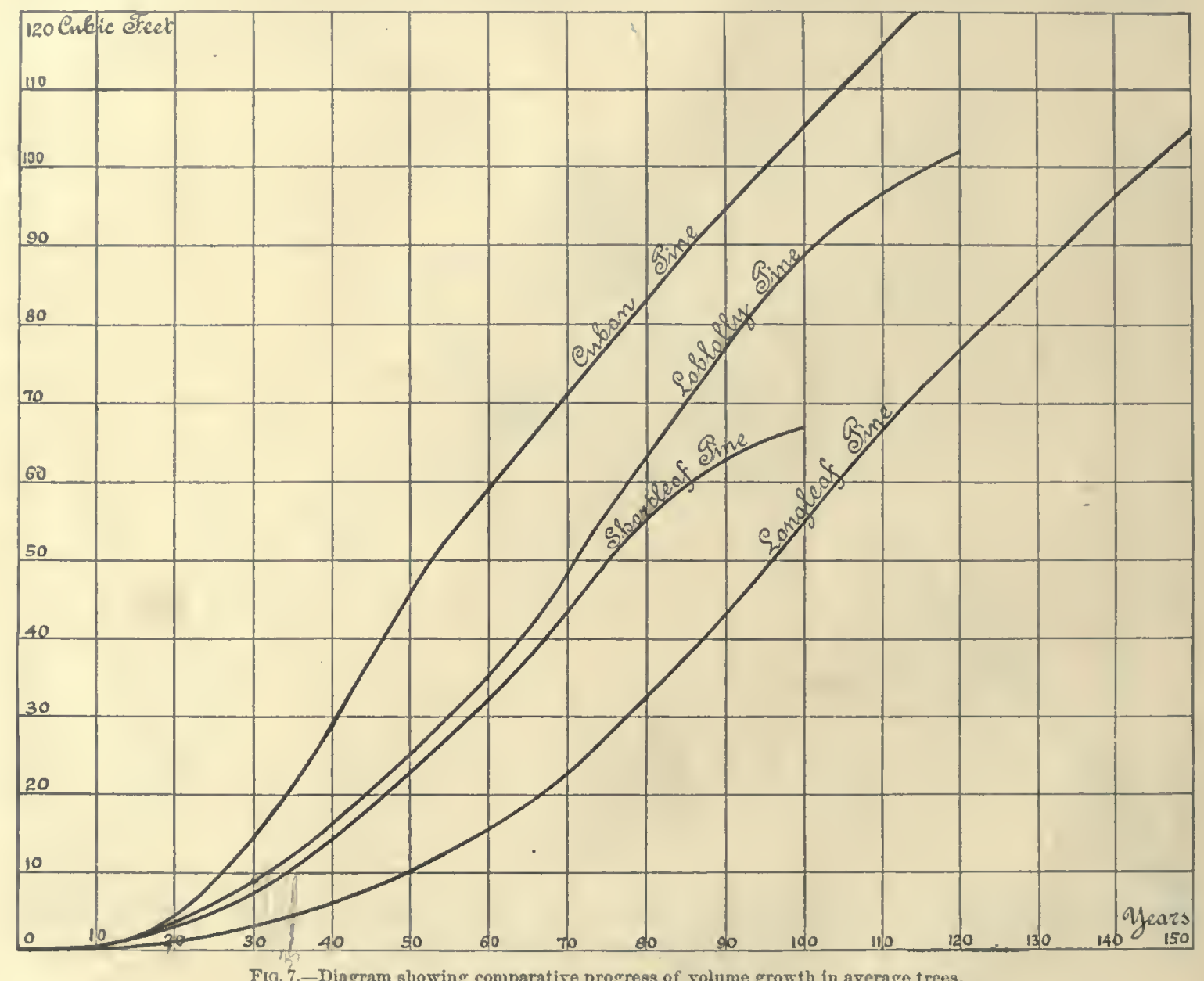

estimated and hence made them appear below the truth, has now sunk nearly to the lorrest level, any stick that ean be placed on the mill down to 10 -inch and S.inch being fit material. There is also no danger of any reduction in the cut for any reason exeept a temporary one due to such general bnsiness depression as that experienced thronghout the Inst two years. Increase of consumption of Sonthern timber is bound to follow the imminent exhaustion of the pine supplies of the North. And with the exception of l'acific Const timbers, which,owing to their great distauce, have so far made but little competition in Eastem uarkets, no new nndiseovered timber resource will inflnence the cut of' Sonthern pine.

Venturing on the basis of the meager data furnished in this publication to make a guess at the probable suply and demand, we may with due reserve state that the annount of pine timber ready for lumber inannfacture standing in the Sonth can not be above $250,0100,000,000$ feet, and 
more likely will fall far below $200,000,000,000$ fect, while the figure for present and lowest future annual cónsumption may be approxinted at near 7,000,000,000 feet, board measure.

There is nobody who knows or can know the actual condition of supplies, and whoever has au opinion on the subject will have to bring at least as good a basis or a better one for such opinion than the data furnished in the following monographs.

There is 110 attempt to predict from the foregoing figures the absolute exhaustion of the pine supplies of the Sonth within forty or fifty years, although such a result would appear not unlikely. Competition of other timbers, and substitutes for the use of wood (which, to be sure, never in the history of the world have rednced wood eonsumption), and espccially changes in present methods of exploitation, may lengthen out supplies for a short time; or, if we begin rational forestry now, these forests may be kept a source of continnous supplies, even though redueed.

Those who rely upon the spontaneous natural reproduction of these pines to fill the gaps made in the virgin timber will do well to read the chapters on natural reproduction and the ineidental remarks legarding the conditions for renewal and the appcarance of the aftergrowth; or, lettcr, trantp through the vast region of culled pine woods and observe what the basis of their relianee is, as the writer of these monographs has done through forty years of his life. If, in addition, they study the chapters on eonditions of development, they will realize that the Longleaf Pine is bound to disapuear largely even in the regions where it reigned supreme; that the Cuban Pine, no despieable substitute, will take its place in the lower pine belt, if allowed to propagate at all; but - on large burnt areas the growth of serubby oaks and boush will forever exchule this species whieh eminently needs light. Loblolly and Shortleaf, better fitted for warfarc with other species, will do much in their respective habitats to reenperate, except in the mixed forcst, whre they are culled and the hard woods are left to shade out the aftergrowth; or where the continnons conflagrations have destroyed the mold and aftergrowth and given over the soil to serubby brushgrowth, which for ages will either prevent the gradual return of the pines or imperle their renewal and growth. Considering that the timber on which we now rely and on which we base our standards comes from trees usinally from one hundred and fifty to two hundred years or nore old, and that none of these pines makes respectable timber in less than from sixty to one hundred and twenty-five years, the necessity of timely attention to their renewal is further emphasized.

The owners of timber land and the operators of mills are the only people who can improve these conditions, and this by a more rational treatment of their property. If they can be made to realize now that what they own and hold as a temporary speculation will, in a short tine, when supplies have visibly decreased, beeome a first-class investment, and, by its revenues, beeome a greater source of wealth under competcnt management with a view to reproduction than that whieh they have derived from it by the mere robbing of the old timber, they might take steps at least against the umecessary damage done to it by fire and eattle. Permanency and eontinuity of ownership appear to be the first condition to insure such results, and therefore eorporations which are not of an ephemeral eharacter and nen of large wealth are most desirable forest owners.

The monographs here presented will, it is hoped, aid in this realization, and the information regarding the eonditions of devclopment of the different species will furnish suggestions as to the forest management which, modified according to loeal conditions and eeonomic eonsiderations, may be employed to secure the perpetnity of the Southern pineries.

\section{Wasingatos, D. C., June 5, 1896.}

\section{B. L. FenNow.}

1 The entire regiou within which these pines occur in merchantablecondition comprisos about 230,000 square miles or, in roumel numbers, 147,000,000 acres; for land in furus, etc., 10,000,000 acres must be deducted, and allowing as mnch as $t$ wo-thirds of the remainder as representing pine lands (tho other to hardwoods), wo wonld have abont $90,000,000$ acres on which pine may orcur. An averago growth of 3,000 feet per acre, an extravagant figure when referred to snch su area, would mako tho possible stand $270,000,000,000$ fcet, provided it was in virgin condition and not mostly cullerl or cut. 


Plate II.

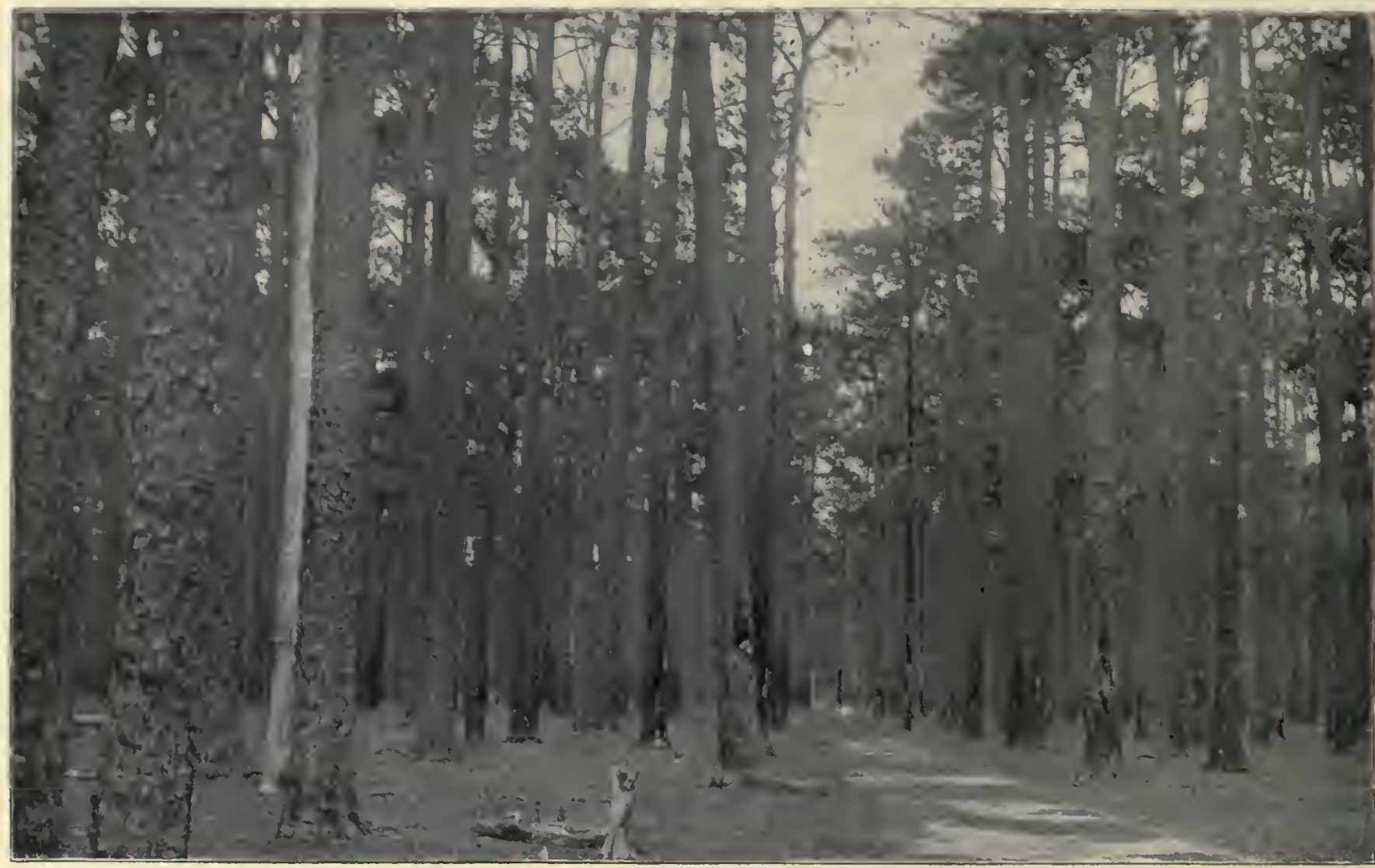

Fig. 1.-Longleaf Pine forest in louisiana flats, Virgin, Scorched by fire as Usual.

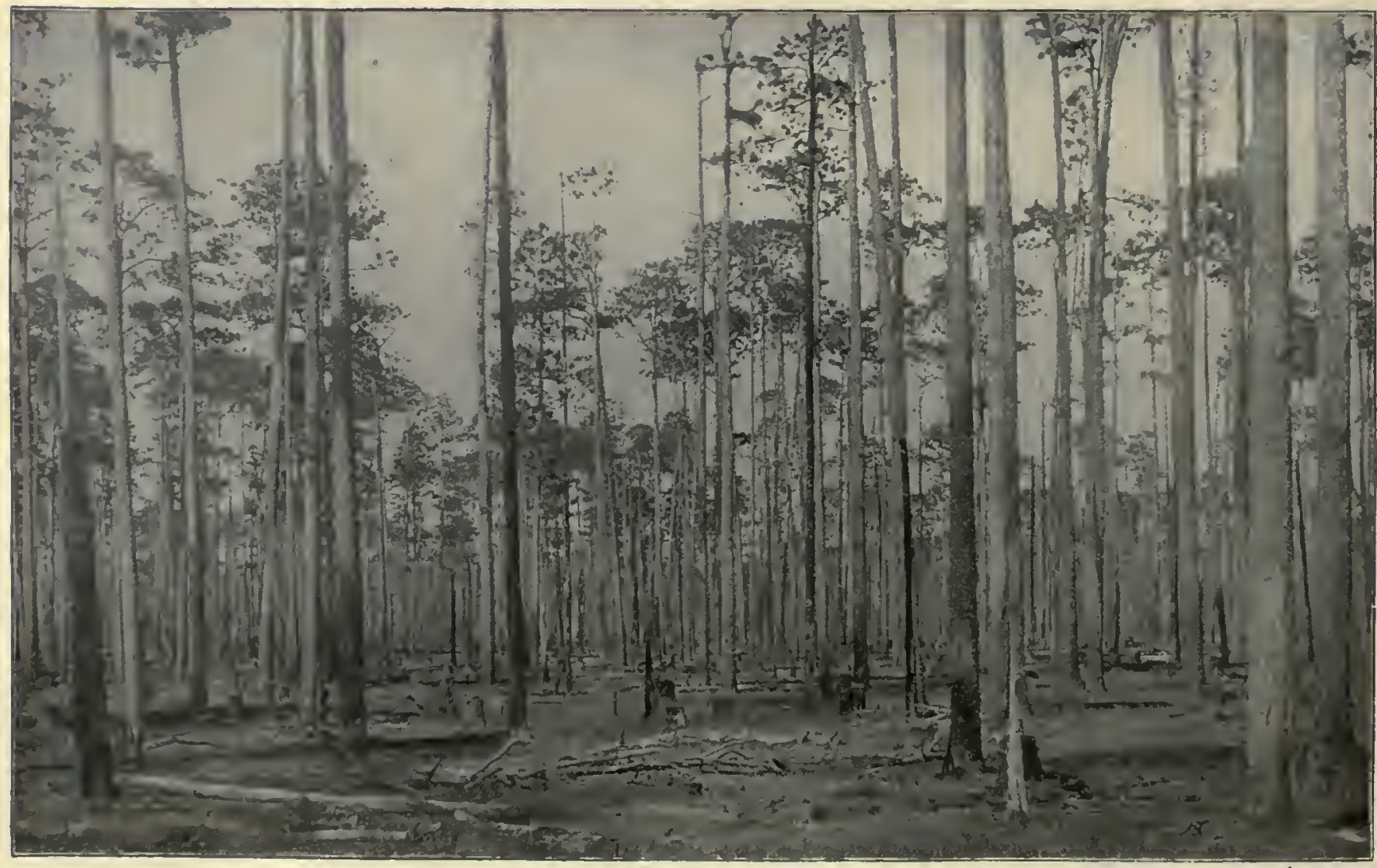

Fig. 2. Longleaf Pine forest after Removal of Merchantable timber. 


\section{THE LONGLEAF PINE.}

(PINUS PALUSTRIS Miller.)

Geographical Distribution.

Products and Uses.

Botanical Description.

DESCRIPTION OF WOOD.

Progress of DeVelopyent.

Conditions of Developient.

Forest Management.

Appendix: 'Tie Naval Store Industry.

Longleaf Pine in Higinlands.

Additional Notes on Longleaf Pine. 


\section{THE LONGLEAF PINE.}

(Pinus palustris Miller.)

Synouyms: Pinus palustris Miller, Gard. Dict., eul. 8, No. 14 (1768).

Pinus lutea Walter, Fl. Car.,237 (1788).

Pinus australis Michaux f., Hist. Arb. Am., i. 64, t. 6 (1810).

Pinus serotina Hort. Cf. Bon Jard. 976 (1837) ex Antoine, Conif., 23 (1840-'47), not Michx. (1803).

Pinus Palmiensis Fr. Garl. ex Gordon, Pinetnm, ed. 1, Suppl., 63 (1862).

Pinus Palmieri Manetti ex Gord., 1. c. (1862).

\section{LOCAL OR COMNON NAMES.}

Longleaved Pine (Del., N. C., S. C., Ga., Ala., Fla., Miss., La., Tex.).

Southern Pino (N. C., Ala., Miss., La.).

Yellow Pine (Del., N. C., S. C., Ala., Fla., La., Tex.).

Turpentine Pine (N. C.).

Rosemary Pino (N.C.).

Brown Pine (Tenn.).

Hard line (Ala., Miss., La.).

Georgia Pine (Del.).

Fint Pine (Southern States).

- Soutliern Yellow Pine (gencral).

Southern Harl Pine (goneral).

Sonthern Heart Pine (general).

Sonthern Pitch Pino (goneral).

Heart Pine (N. C. and Southern Atlantic region).
Pitch Pine (Atlantic region).

Longleaved Yellow Pine (Atlantic rogion.) Longleaved Pitch Pine (Atlautic region).

Long-straw Pine (Atlantic region).

North Carolina Pitch Pine (Va., N. C.).

Georgia Yellow Pine (Atlantic region).

Georgia Pine (general).

Gcorgia Hcart Pine (general).

Georgia Longleaved Pine ( $\Lambda$ tlantic region).

Georgia Pitch Pine (Atlantic region).

Florida Yellow Pine (Atlantic region).

Florida Pine (Atlantic region).

Florida Longleaved Pine (Atlantic region).

Texas Yellow Pine (Atlantic region).

Texas Longleaved Piue (Atlantic region). 


\title{
THE LONGLEAF PINE.
}

\author{
By Charles Momr, Ph. D.
}

\section{INTRODUCTORY.}

The Iongleaf Pine is the tree of widest distribution and of greatest commercial importanee in the Southeru Atlantic forest region of eastern North America, covering, with scarcely any interruption, areas to be measured by teus of thousauds of square iniles and furnishing useful matcrial.

The timber wealth of the forests of Longleaf Pine, much of which is still untouched, has given rise to industries which involve the outlay of vast capital and an cxtensive employment of labor, thus closcly affecting the prosperity of a large part of the Southern States as well as the industrial and commercial interests of the whole country.

With the impending exhaustion of thc pine forests of the Nortl, the lumber interests of the country are stendily tending to center in the South, attracted chiefly by the forests of Lon gleaf Pine.

The Old World, which has heretofore depended almost cntirely upon the piuc forests of Canada and of the Northern Uuited States for timber for heavy construction, is alrcady importing a large amount of hewn and sawn square timber and of lumber from the Southern pine forests. Most of the lumber uscd for ordinary building purposes in the West Indies, on the coast of Mexico, and in many of the States of South America is furnished by the mills situated in the Longleaf Pine region. The unprecedented increase, during the last quarter of a ccitury, of the population in the timberless regious of the far West, as well as in the country at large, enormously augments the drafts made upon these forests, threateuing their eventual exhaustion and ultimate destruction unless measures are taken by which these supplies may be perpetuated. The solution of the difficult problem of devising such measures can comc only as a result of a study of the life history of the Tongleaf Pine, of the conditions required for its growth and best development, of the laws regulating its distribution, and of the possibilities for its natural or artificial restoration.

\section{HISTORICAL.}

The economic importance of the Lougleaf Pinc was well recognized in early times. Bartram, ${ }^{1}$ in tise ycar 1777, in his wanderings along the western shore of Mobile Bay, had his àtentiou attracted by three very large iron pots, or kettles, each with a capacity of several hundred gallons, near the remains of an old fort or settlement, which he was informed were used for the purpose of boiling down the tar to pitch, there being vast forests of pine in the vicinity of this place. "Iu Carolina," this writcr proceeds, "the inhabitants pursue a different method. When they are going to make pitch they dig large looles in the ground, which they line with a thick coat of good clay, into which they conduct a sufficient quantity of tar and set it on firc, sufferiug it to burn and cvaporate for some time, in order to convert it into pitch, and when cool, put it into barrels until they have consumed all the tar and madc a suficient quantity of pitch for their purposes."

Humphrey Marshall, one of the earliest writers on North Amcrican forest trecs, ${ }^{2}$ mentions the Longlcaf Pinc uuder the name of the "largest three-lcaved marsh pine, as accounted equal to any for its resinous products." In North Caroliua crnde resin, tar, and pitch figured as important and valuable exports during the later colonial times. During the period from 1766 to $1769, \$ 130,000$

\footnotetext{
'Bartram's Travels throngh North and Sonth Carolina. Philadelphia, 1791.

"Jumphry Marshall: "Arbustrum Anericanum," or the Amer"can Grove. Philadelphia, 1785.
} 
worth of these stores were exported yearly; among then were 88,111 barrels of crude resin, valued at $\$ 11,244.85$. F. A. Miehanx, in his travels east of the Alleghany Mountains, speaking of the low eonutry of the Carolinas, says:" "Seven-tenths is 'covered with pine of one speeies, Pinus palustris, whieh, as the soil is drier and lighter, grows loftier; these pines, eneumbered with very few branehes aul which split even, are preferred to other trees for building fences on plantations." In his subsequent work Michaux gives for the first time an aceurate and detailed aeeount of the products of this trec and their industrial and commercial importanee, as well as of its distribution and a deseription of its speeifie charaeters. ${ }^{2}$

Note.-In skotching the topographical features of those regions of tho Longloaf Pine forests, which did not come undor the personal obscrvation of the writor, tho physiographical descriptions of tho Cotton States on the Atlantic Coast axd the Gulf region published iu Professor llilgarl's report ou cotton produetion in the fifth and sixth volnmes of tho Census of 1880 were freely drawn upon, and these reports were also eousnltod, together with Table VII, in the statistics publishod in the census report on productions of agriculture in tho eomputation of forest areas.

In the statemonts of the anount of Longleaf Pine standing in the several States in 1880 and of the cut during the saue year, the figures given in Prof. Charles S. Sargent's report, Vol. IX of the Teuth Census, were introducer, aud for those which relate to Alabama and Mississippi the writer is mostly responsible. No efforts haro been spared to arrivo at a eorrect estimate of the total amount and valne of sclnare timber, lumber, and naval stores produeed during the decade ending with the year 1890 aud duriug tho bnsiness year 1893, in order to place in a proper light the ceonouio importanee of the troe and its bearings upon tho indnstrial and eomuereial iuterests of the conntry, and also to slow tho rapid increase of tho industries depending directly upon the resources of this treo. The statemonts given aro, bowever, of neccsity only approximations falling below the limits of trutb, as it was impossible to aseertain with any degroe of aecuracy the quantitios entering into home consumption. Thus a factor of no little importanoe had to be nogleeted.

The thanks of the writer aro due to tho gentlemen who kindly assisted him by thoir prompt replies to his inquiries in his search for information, and who in other ways have afforded him aid.

\section{GEOGRAPIICAL DISTRIBUTION.}

The Longleaf Pine is principally eonfined to a belt about 125 miles in width in the lorer parts of the Southern States which border upon the Atlantie and the Gulf shores. The northern limit of the tree is found on the eoast near the sonthern boundary of Virginia below Norfolk, north latitude $36^{\circ} 30^{\prime}$. From here the forests of the Longleaf Pine extend south ward along the eoast region to Cape Canaveral, aeross the peninsula of Florida a stort distanee sonth of Tampa Bay, westward along the Gulf Coast to the uplands whieh border upon the alluvial deposits of the Mississippi. West of that river forests of this species eontinue to the Trinity kiver in Texas; in that State its northern limit is found to reaeh hardly $32^{\circ}$ north latitude, while in Lonisiana and Mississippi it extends hardly more than half a degree farther north, and in Alabana under $34^{\circ} 3 u^{\prime}$ the tree is found to aseend the extreme sonthern spurs of the Appalaehian ehain to au altitude of between 1, 500 and 2,000 feet. Thus the area of the distribution of the Longleaf Pine extenls from $76^{\circ}$ to $96^{\circ}$ west longitude and from $26^{\circ} 30^{\prime}$ to $36^{\circ} 30^{\prime}$ north latitude. (See Pl. III.)

With refereneu to the distribution of this speeies as depending upon geologieal formation, it may be said that its forests are chiefly confined to the sandy and gravelly deposits designated by Professor Hilgard as the orange sand, or Lafayette strata of Post- Certiary formation, whieh of late isregarded as the nost recent member of the Tertiary formation. Thesesiliceons sands and pebbles, which to sneh vast extent eover the lower part of the Southern States and form also more or less the eovering of the surface throughout the older Tertiary region, ofler the physieal conditions most suitable to the growth of this tree.

\section{OIIARACTERISTICS OF DISTRIBUTION IN DIFFERENT REGIONS.}

This great maritime pine belt east of the Mississippi liver presents sueh differences in topographieal features and sueh diversity of physieal and meehanieal eonditions of the soil as to perınit a distinetion of three divisions going from the eoast to the interior:

1. The coastal plain, or low pine barrens within the tide-water region, extends from the seashore inland for a distance of from 10 to 30 miles and over. The forests of the Longleaf Pine which

\footnotetext{
${ }_{1}^{1}$ Mímoiro sur lu naturalisation des arbres forestiers de l'Aueriqne septentrionale, by F. A. Michanx. P’iris, 1805.

${ }^{2}$ F. A. Michanx, 11 istoire des Arbres forestiers de l'Amer., Sept. Paris, 1810-1813. Linglish translation, Plilitdelphia lidition, 1859, Vol. III, p. 106 et neq.
} 


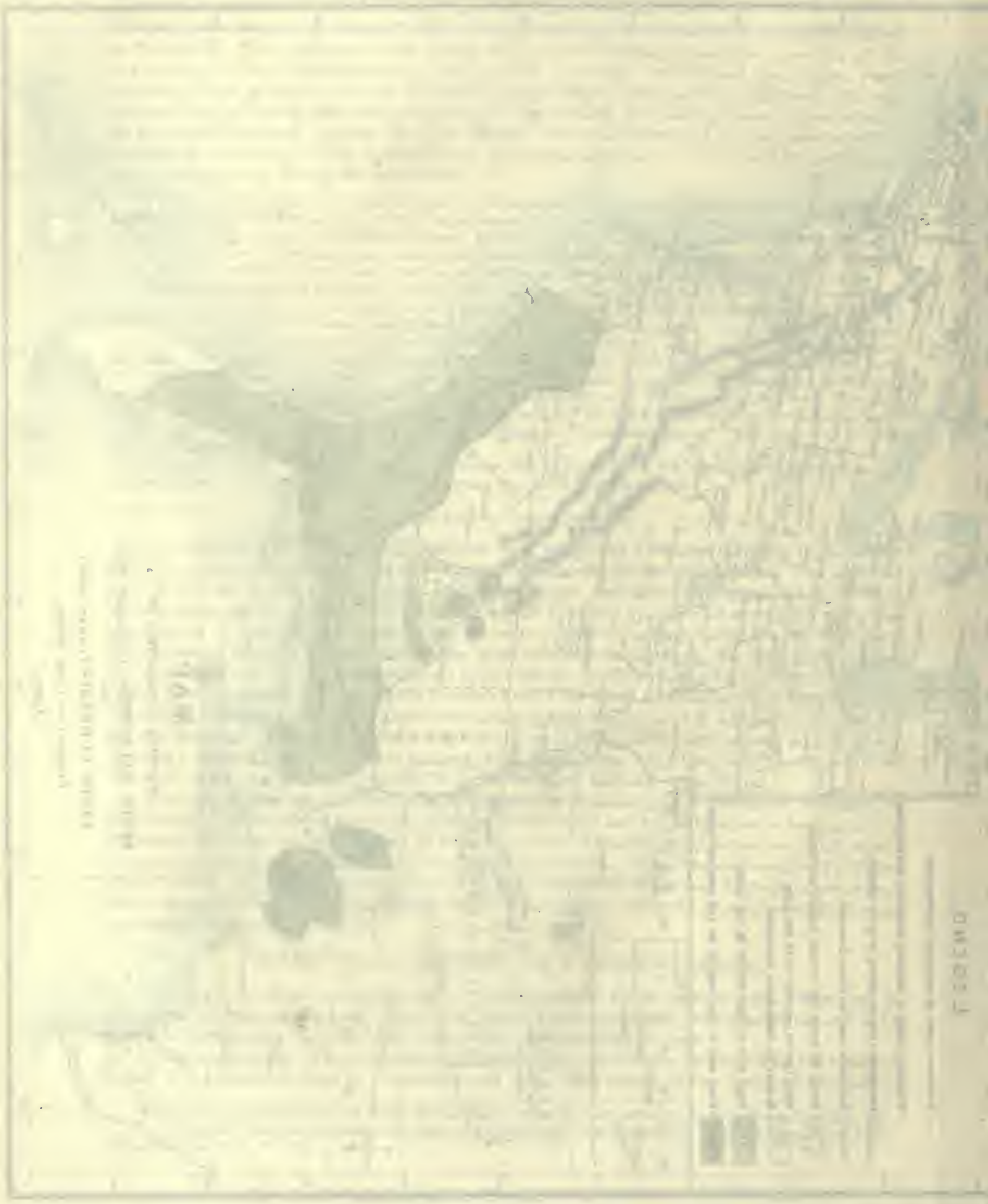


oeenpy the poorly drained grassy flats of the plain are very open, intersected by numerous inlets of the sea and by brackislı marshes. They are also interrupted by swamps denscly eovererl with Cypress, White Cedar, White and Red Bay, Water Oak, Live Oak, Magnolia, Tupelo Gum, and Blaek Gum and again by grassy savanmas of grenter or less extent. On the higher level, or what might be called the first terrace, with its better drained and more loamy soil, the Longleaf Pine once prevailed, bnt almost everywhere in the eoastal plain the original timber has been removed by man and replaced by the Loblolly Pine and the Cuban Pine.

2. The rolling pine lands, pine hills, or pine barrens proper are the true home of the LongLeaf Pinc. On the Atlantic Coast these uplands rise to hills over 600 feet in height, while in the Gulf region they form broad, gentle nudulations rarely exceeding un elevation of 300 feet. Thus spreading out in extensive table-lands, these hills are covered exclnsively with the forests of this tree for many hnndreds of square miles withont interruption. Here it reigns supreme. The monotony of the pine forests on these table-lands is unbroken.

3. The upper division, or region of mixed growth. With the appcaranee of the strata of the Tertiary formation in the upper part of the pine belt, the pure forests of the Longleaf Pine are eonfined to the rilges capped by the drifted sauds and pebbles and to the roeky heights of silieeous ehert, alternating witl open woods of oak (principally Post Oak), which occupy the richer lands of the calcareous loams and marls. However, where these loams and marls, rieh in plant food, mingle with the drifted soils, we find again the Longleaf Pine, but assoeiated with broad-leaved trees and with the Loblolly and Shortleaf Pine. Here the Longleaf Pine attains a larger size and the number of trees of maximum growtl per aere is found almost double that on the lower division.

TIMBER REGIONS-SUPPLY AND PRODUUTION.

The forests of Longleaf Pine can be eonveniently diseussed by referring to the following geographieal and limited areas:

The Atlantie pine region;

The maritime pine belt of the eastern Gulf States;

The eentral pine belt of Alabana;

The forests of Longleaf Pine of nortl Alabama (Coosa basin, ete.);

The regions of Longleaf Pine west of the Mississippi River.

THE ATIANTIC PINE REGION.

The Atlantic pine region in its extent from the southern frontier of easteru Virginia to the peninsula of Florida embraces the oldest and most populous States of the Longleaf Pine distriet, and here the forests have suffered inost severely by lumbering, the production of naval stores, and elearing for purposes of agrieulture.

Virginia.-The forests of the Longleaf Pine on the sontheastern border of Virginia have almost entirely disappeared, and are, to a great extent, replaced by a second growth of Ioblolly P'ine.

North Carolina.-In Nortl Carolina the area over whieh this tree once prevailed may be estimated at from 14,000 to 15,000 square miles, leaving out of caleulation the eoastal plain with its extensive swamps, wide estnaries, and numerous inlets. From the northern frontier of the State soutliward, some distance beyond the Nense River, in the agricultural district, the forest growth on the level or but sliglitly indulating pine land is of a mixed eharacter, the Longleaf speeies being largely superseded by the Isoblolly Pine, together with widely scattered Shortleaf Pine and decidnous trees-White Oak, lied Oak, Post Oak, Black Oak, and more rarely Mockernnt and Pignut IIickory, and Dogwood. In this seetion the lumbering interests are ehiefly dependent upon the Loblolly P'ine (Pinus terla), better known to the inhabitants as the Shortstraw, or Shortleaf Pine (not to be eonfounded with the true Shortleaf Pine). The forests of Longleaf Pine begin at Bogne Inlet, extend along the coast to the southern boundary of the State, and inland for a distanee varying between 50 and 135 miles.

The higlly siliceous soil of these pine barrens offers but little indueement for its cultivation; the inhabitants, therefore, from the earliest time of the settlement of the State have chiefly been engaged in pursuits based on the produets of the pine forests. Here the prodnction of naval 
stores was first earried on; rosin, tar, and piteh fignred in early colonial times among the most important artieles of export. In eonsequence, the forests of the Longleaf Pine liave been, with but slight exceptions, invaded by turpentine oreharding, and at the present time by far the greater part of the timber standing lass been tapped for its resin. The forests of the Longleaf Pine in this State eover the largest area in the basin of Cape Fear River, with Wilnington the main port of export for their prodnets. 'The export from this port liad inereased from 21,000,000 feet of lumber in 1880, to nearly 40,000,000 anninlly, on the average, for the years $18 \times 7$ to 1891.

The forests of the Longleaf Pine on the banks of the Nense River, in .Johnston County and in Wayne Connty, are almost exhansted; less than 10 per cent of the timber saw at Coldsbono and Dover is Longleaf Pine timber from that section, ancl is invariably bled. A consirlerable number of the trees from the old turpentine orchards, with the exeoriated surface of the trunk ("ehip") over 25 feet in length and bled again after a lanse of years, show that they have leen worked for their lesin for twenty to twenty-fonr years in suecession, and after a longer or shorter period of rest have been subjeeted to the same treatment eontinnally for the same number of years. Sineliold unartyrs of the turpentine orehard are unfit for lunber, but, inpreguated as they are with resill, are used for piling and for posts of great durability.

East of the Nense River, from the upper part of Johnston Connty, in an almost southern direetion to Newbern, no Longleaf Pine lias been observed. Single trees of the Shortleaf Pine (I'inus echinata) have been fonud seattered among the growth of deeiduous trees whieh eover the ridges between the Trent and Neuse rivers, and isolated tracts of a few aeres of the Longleaf species are met with in the low flats of the same seetion, whieh were in 1894 almost exelusively oceupied by the Loblolly Pine.

As reported for the Tenth Census, the amount of Longleaf Pine standing in Nortl Carolina at the beginning of the eensus year was estimated to be $5,229,000,000$ feet, board inensure. No reliable information eould be obtained as to the anount of timber eut sinee 1880, consequently no data are at hand from which to compnte the amonnt now standing. The ent for the year 1880 is given in the census report at $108,400,000$ feet, board measure. In 1890 , eighteen inills were enuneraterl as engaged in sawing exelnsively Longleaf Pine timber, almost all situated in the basin of Cape Fear River, with a daily aggregate eapaeity of 475,000 feet, board measure. Such eapaeity wonld point to an annual eut of at least $65,000,000$ feet, board measure.

Statement of the shipments of naral stores from llilmington, I. C.

[From J. L. Cantwell, secretary Wilmingtou Produce Lxchange.]

\begin{tabular}{|c|c|c|c|c|}
\hline Year. & $\begin{array}{c}\text { Spirits of tur- } \\
\text { pentine. }\end{array}$ & Rosiu. & $\begin{array}{c}\text { Crude resiu } \\
\text { or tarpentive. }\end{array}$ & Tar. \\
\hline & Casks. & Barrels. & Barrels. & Barrels. \\
\hline $1881 \ldots \ldots$ & $\begin{array}{r}129,000 \\
00,000\end{array}$ & 450,000 & 2,323 & $\ldots . .$. \\
\hline $1882 \ldots \ldots$ & 38,370 & 425,925 & 3,188 & 56,113 \\
\hline 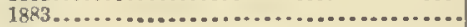 & 87.050 & 483,432 & 31,906 & 75,544 \\
\hline 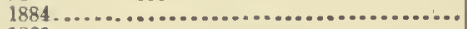 & 78,978 & 434,376 & 45,966 & 85,230 \\
\hline 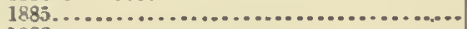 & 71,145 & 310,808 & 35,290 & 70,530 \\
\hline 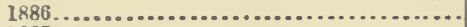 & 03,580 & 324,942 & 25,662 & 61,195 \\
\hline $1887 \ldots \ldots \ldots . . . .$. & 71,912 & 381,335 & 21,572 & 68,143 \\
\hline $1888 \ldots \ldots \ldots \ldots \ldots$ & 63,437 & 240,516 & 18,171 & 63,163 \\
\hline $1889 . \ldots \ldots \ldots . . .$. & 69. 668 & 351,827 & 19,082 & 68,856 \\
\hline ............... & 70,289 & 385,523 & & 71,949 \\
\hline 1891. & 67.480 & 349,500 & 16,900 & 63. $7 \mathrm{co}$ \\
\hline 1892. & 59,283 & 287,200 & 15,510 & 67,900 \\
\hline 1893. & 58,336 & 274,800 & 15,500 & 70,500 \\
\hline $1894 \ldots$ & 46,036 & 189,900 & 9,900 & 45,500 \\
\hline Total. & $1,111,155$ & $5,560,051$ & 261.020 & 869,323 \\
\hline Valno... & $\$ 19,000,000$ & $\$ 10,000,000$ & $\$ 391,500$ & $\$ 1,100,000$ \\
\hline
\end{tabular}

Total value, $\$ 30,500,000$.

Statement of shipments of lumber to foreign and domextic ports from Wilwington, N. $C$.

\begin{tabular}{|c|c|c|c|c|c|}
\hline Year. & $\begin{array}{l}\text { Feet, board } \\
\text { me'saure. }\end{array}$ & Year. & $\begin{array}{l}\text { Feet, bourd } \\
\text { mensure. }\end{array}$ & Year. & $\begin{array}{c}\text { Feet, board } \\
\text { measure. }\end{array}$ \\
\hline $\begin{array}{l}1880 \ldots \ldots \ldots \ldots \\
1881 \ldots \ldots \ldots \\
1882 \ldots \ldots \ldots \ldots \\
1883 \ldots \ldots \ldots \\
1884 \ldots \ldots \\
\end{array}$ & $\begin{array}{l}21,000,000 \\
45,498,480 \\
40,291,146 \\
35,465,000 \\
30,000,000\end{array}$ & $\begin{array}{l}1885 \ldots \ldots \ldots \ldots \\
1886 \ldots \ldots \ldots \ldots \\
1887 \ldots \ldots \ldots \ldots \\
1888 \ldots \ldots \ldots \\
1889 \ldots \ldots \ldots \ldots\end{array}$ & $\begin{array}{l}30,000,000 \\
39,500,000 \\
41,000,000 \\
36,680,000 \\
40,289,000\end{array}$ & $\begin{array}{l}1890 \ldots . \\
1891 \ldots . \\
1892 \ldots \\
1893 \ldots \\
1894 \ldots\end{array}$ & $\begin{array}{l}40,060,000 \\
29,580,160 \\
25,874,331 \\
30,593,930 \\
35,353,412\end{array}$ \\
\hline
\end{tabular}


South Carolinu.-The forests of Longleaf Pine in this State follow nore closely the coast line, with an extension inland averaging 100 miles. The lower parts of the pine belt, or the Savannah region, is low and tlat, rising but slowly above the brackish marshes and alluvial lands borlering the sea. Traversed by eight large livers with wide estnaries and bordered by extensive swamps of Cypress, Magnolia, Red and White Bay, Lanrel Oak, etc., its area lias been estimated to be 7,000 square miles, 4,500 square miles of which are ocenpied by swamp lands, ineluding the grassy marshes on the coast. In the low, perfectly level pine barrens, with a soil of fine, compacted, almost impervious sand, eovered with the Saw Palnetto, the Pond Pine, and a stmuted growtlı of the Cuban and Loblolly Pine, the Longleaf Pine is rarely seen, and always of dwarfed growtl.. In the flat woods bordering the allnvial swamps, heavily timbered with Loblolly and Cuban Pine, the Longleaf P'ine makes its appearance unore frequently, and finally prevails almost exclusively on the broad, dry, sandy ridges, associated with the Barren or Turkey Oak (Quercus catesbcei), stunted Spanish Oak, and Upland Willow Oak (Quercus cinerea), trees of smaller size forming the undergrowtlı. The timber growth on these ridges is rather open and of good quality. As lias been observed near Ridgeland, in the connties of Bcanfort and Hampton, the forests have to a large extent given way to the plow, and along the railroads they have bcen destroyed by turpentine orcharding. Upon 1 acre, representing fairly the original timber growtl of the forests on these ridges, 45 trees of a diameter of from 12 to 24 inches at breast high, with a leight of from 50 to 110 feet, were found. Of these, 4 yielded stieks of clear timber averaging 45 fcet in length with mean diameter of 18 inches, eqnal to 2,000 feet, board measure, of first-class lumber. These trees varied in age from 136 to 145 years; $S$ trees yielded sticks of timber free from limbs 40 feet in length with mean diameter of 17 inches, equal to 3,200 feet, board ueasnre, age on the average 140 years; 12 trees yielded 35 feet length of elear timber with mean diameter of 16 inehes, equal to 3,600 feat of merchantable limber, age from 130 to 136 years; 8 trees averaged 12 inches mean diameter, length of timber 30 feet, equal to 950 feet, board ueasure, age from 110 to 118 years; 4 trees averaged 10 inches mean diameter, length of clear timber 24 feet, wood sappy throughont, yielding 200 feet of lumber, age from 80 to 85 years.

The total yicld of unerehantable lumber of this acre would be 9,950 fect, board measnre, representing the average of the better quality of these timber lands. As in the adjoining States, the forests along the railroad lines for a wide distance have bcen subjected to tnrpentine oreharding, anc but a small pereentage of the timber standing has eseaped the ax of the "box" eutter. The receipts of naval stores at Charleston during the ten years from 1880 to 1890 averaged ammally 57,570 casks ( 50 gallons to a cask) of spirits of turpentine and 225,920 barrels of rosin, with the largest receipts in 1880 of 60,000 casks of spirits of turpentine and 259,940 barrels of rosin, and the smallest of 40,253 ussks of spirits in 188s, and 149,348 barrcls of rosin in 1889 .

Tabular statement of the shipments of naval stores at Charleston, S. C., from the beginning of 1850 to the clowe of the year 1894.

[From the anmal statements of the "onmerce of Cluarleston, s. C., puhliched in the Charlestou Courier."]

\begin{tabular}{|c|c|c|c|c|c|}
\hline Tear. & $\begin{array}{l}\text { Sipirits of } \\
\text { turpentine. }\end{array}$ & & Year. & $\begin{array}{l}\text { Spirlts of } \\
\text { turpentine. }\end{array}$ & Rosin. \\
\hline $\begin{array}{l}1880 \ldots \ldots \ldots \ldots \\
1881 \ldots \ldots \ldots \ldots \\
1882 \ldots \ldots \ldots \ldots \\
1883 \ldots \ldots \ldots \ldots \\
1884 \ldots \ldots \ldots \ldots \ldots \\
1885 \ldots \ldots \ldots \ldots \ldots\end{array}$ & $\begin{array}{l}\text { Casks, } \\
60,000 \\
51,386 \\
09,027 \\
65,914 \\
64,207 \\
44.126 \\
40.375\end{array}$ & $\begin{array}{r}\text { Barrels. } \\
259,940 \\
231,417 \\
258,446 \\
285,440 \\
264,049 \\
218,971 \\
170,060\end{array}$ & $\begin{array}{l}1889 \ldots \ldots \\
1890 \ldots \ldots \\
1891 \ldots \ldots \\
1892 \ldots \ldots \\
1893 \ldots \ldots \\
1894 \ldots \ldots\end{array}$ & $\begin{array}{r}\text { rasks. } \\
43,127 \\
49,232 \\
35,414 \\
25,969 \\
22,543 \\
14,415\end{array}$ & $\begin{array}{r}\text { Barrels. } \\
149,348 \\
217,865 \\
163,816 \\
127,262 \\
121,024 \\
71,329\end{array}$ \\
\hline $1887 \ldots \ldots \ldots \ldots$ & $\begin{array}{l}52.549 \\
40,253\end{array}$ & $\begin{array}{l}171,154 \\
181,886\end{array}$ & $\begin{array}{l}\text { Total ...... } \\
\text { Vulue.... }\end{array}$ & $\begin{array}{r}678,537 \\
\$ 11,874,397\end{array}$ & $\begin{array}{r}2,892,614 \\
\$ 5,206,714\end{array}$ \\
\hline
\end{tabular}

- The annual receipts on the average equal the exports.

The rolling pine hills borlering npon the flat woods, or swamps, reaeh elevations of 130 to 230) feet above the sea, with a wid th of from 20 to 40 miles, and, as on the piue ridges of the low pine barrens inentioned before, the npland oaks form the sparse undergrowth in the forests of Longleaf l'ine. Nearly onc-third of the area (estimated at abont 4,500 square miles) has been opened to cultivation. These rolling pine lands rise on their northern borders abruptly to a range of stcep hills over 600 feet above sea level, covererl with a rather seanty growth of Longleaf $7092-$ No. $13-3$ 
Pine among the Shortleaf Pine and fine upland oaks, the latter largely prevailing. On the sonth and west tliese hills nerge into an elevated platean with a loose soil of coarse white saucl. llere the Longleaf l'ine is found in its full perfection and furnishes timber of exeellent quality. ${ }^{1}$ Abont 12 per eent of these pine-elad table-lands are under cultivation, and about 22 jer cent of the hills, with their generous red soil, are covered with a mixed growtl of pine and oak; both of these divisions eover an area of not less than 4,000 square miles. ${ }^{2}$

The Iongleaf Pine timber standing in South Carolina in the eensus year 1850 was estimated at $5,316,000,000$ feet, board measure, ${ }^{3}$ with an anmul cut of $124,000,000$ feet.

In 1890 forty mills sawing exelusively Longleaf Pine timber have been reported ${ }^{4}$ with au aggregate daily eapaeity of about 510,000 feet, taken at the lowest figure. This would indicate for that year a cut of $68,000,000$ feet, boarl measure, which may also be eonsidered the average annual ent for the last fifteen years.

The exports of lumber from Charleston, the chief port, have sinee the year 1850 steadily iuereased, the excess in 1890 over the amount in 1880 reaehiug over 400 per eent, as is exhibited in the following statement: Statement of lumber exported from Charleston, S. C., to foreign and domestio ports from the beginning of 1880 to the close
of 1834.

[Inoludes considerable Loblolly and Shortleaf Pine.]

\begin{tabular}{|c|c|c|c|c|}
\hline & Tear. & $\begin{array}{l}\text { Feet, board } \\
\text { mensuro. }\end{array}$ & Year. & $\begin{array}{l}\text { Feet. board } \\
\text { measare. }\end{array}$ \\
\hline $\begin{array}{l}1879-80 . \\
1880-\times 1 . \\
1841-82 . \\
188 \pm-63 . \\
1881-84 \\
1884-85 \\
1885-86 . \\
1886.87\end{array}$ & 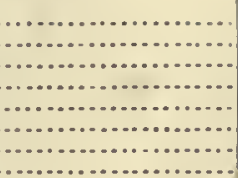 & $\begin{array}{l}15,437,000 \\
18,500,000 \\
43,000,000 \\
40,000,000 \\
35,589,000 \\
30,034,000 \\
26,800,000 \\
32,672,000\end{array}$ & 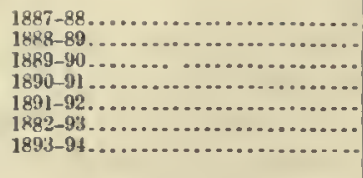 & $\begin{array}{l}45,270,000 \\
50,532,000 \\
68,4(\omega, 000 \\
61,226,827 \\
53,286,608 \\
61,493,344 \\
69,940,453\end{array}$ \\
\hline
\end{tabular}

Georgia.-The great pine State of the South, which has given to the Longleaf l'ine the nane of Georgia Pine, by which this lumber is known the world over, enbraces the largest of the Atlantic pine forests. At a rough estimate, these cover over 19,000 square miles, including the narrow strip of live-oak lands borlering the seashore. The flat woods and savannas of the coast plain are from 10 to $1 \check{b}$ miles wide. They are almost entirely stripped of their growth of Lougleaf Pine.

- The upland pine forests, the pine barreus proper, or wire-grass region, ${ }^{5}$ enbrace over 17,000 square miles. This region forms a vast plain, nearly level exeept on tho north, covered exelusively with Longleaf Pine. Abont 20 per cent of these lands liave been cleared for cultivation.

Formerly the prineipal sites of the lunber industry were Darien, Brunswick, and Savannah. The logs were rafted huucheds of miles down the Savannah, the Ogeechee, the Altanalia and its large tributaries, the Oconee and Ocmulgee. A limited quantity is carried down the Flint and Chattahooehee rivers to Apalachicola. The railroads, however, supply the mills now to the largest extent.

The forests of these pine uplands are in quality, aud originally in quantity, of their timber resourees equal to any found east of the Mississippi. River. The soil is a loose sand, underlaid by a more or less sandy buff-eolored or reldish loan. The almost level or gently undulating plain beeomes slightly broken along the water eourses, and the forests of Longleaf Pine are interrupted by wide, swanpy bottoms which inelose the streans and are heavily timbered with the Loblolly Pine, Cuban Pine, Laurel Oak, Water Oak, Magnolia, White and Red Bay, and Cypress. On the better elass of the pine-timber lands the anount of marketable timber found varies between 3,009 and 10,000 feet to the aere. The trees yielding lmuber and square. sawn timber of the highest

'Kirk IIammond, Census Report, Vol. VI, Cotton production of Sonth Caroliua.

Illawinond, $1 \mathrm{c}$.

"Report of 'Tenth Census, Vol. IX.

'Lunber Trade Directory, Northwestern Lumberman, Chicago, July, 1890.

${ }^{5}$ From the so-called wire-grass Arinticla stricta, the most characteristic plant of the dry, sandy, pine barrens from western Alabama to the Atlantic coast. 
grade were found to make sticks of from 40 to 45 feet long, perfectly clear of limb knots, and 18 to 22 inches mean diameter, giving from 450 to 750 feet of lumber, with the sapwood from $1 \frac{1}{2}$ to 2 inches wide.

The following measurements of trecs from a small tract of forest untouched by the ax serve as a fair average sample of its timber growth:

\begin{tabular}{|c|c|c|c|c|c|}
\hline Number of tree. & $\begin{array}{l}\text { Diameter, } \\
\text { breast high. }\end{array}$ & $\underset{\text { diameter. }}{\text { Mean }}$ & $\begin{array}{l}\text { Length of } \\
\text { timber. }\end{array}$ & $\begin{array}{c}\text { Total } \\
\text { heigbt. }\end{array}$ & $\begin{array}{c}\text { Nnmber of } \\
\text { ringg. }\end{array}$ \\
\hline 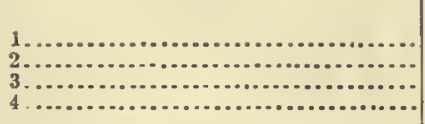 & $\begin{array}{r}\text { Inches. } \\
28 \\
22 \\
19 \\
18\end{array}$ & $\begin{array}{r}\text { Inches. } \\
22 \\
18 \\
15 \\
15\end{array}$ & $\begin{array}{r}\text { Feet. } \\
45 \\
40 \\
40 \\
40\end{array}$ & $\begin{array}{r}\text { Feet. } \\
93 \\
100 \\
96 \\
93\end{array}$ & $\begin{array}{l}250 \\
210 \\
150 \\
138\end{array}$ \\
\hline A rerage.... & 213 & $17 \frac{1}{6}$ & 414 & 97 & 194 \\
\hline
\end{tabular}

Along the numerous railroad lines and the navigable streams and their tributaries admitting of the driving of logs, the forests have been completely stripped of their mcrchantable timber, and the denuded areas to a cousiderable extent are at present under cultivation. The magnifcent forests on the Altaliama River and between its tributaries, the Ocmulgec and Oconee rivers, and als, on the Ogecchee River, have been practically exhaustcd and arc utterly devastated by the tapping of the trees for turpentine. In fact, more than two-thirds of all the timber sawn at present has been bled. The timber from the turpentine orchards, abandoned for years past, is being rapidly removed to thc mills, and the vast areas occupied by them will, within a short time, be almost completely denuded of the Lougleaf Pine, its place being takeu by scrubby oaks, dwarf hickories, and Persimınon. The timber is transferred to the mills mostly by steam-equippad tramroads, and the products of the turpentine distilleries in the remoter districts are hauled to the highways of commerce by ox teams for distauces of 12 miles and over.

Considering the removal for their timber of trees far below medium size and during the best period of their growth, the destruction of still younger trees by turpentine orcharding, and ot the young seedlings by fire, the prospect for the future of the lumber industry and the rencwal of the forests of Longleaf Pine in this region are gloomy. Many of the intelligent men practically intercsted in the timber lands of this State aver that the exhaustion of the forests of the Longleaf Pine is a question of but a short space of time, to be accomplished before another generation has passed.

The amount of timber standing at the end of the census year 1880 liad been computer at $16,778,000,000$ feet, board mcasure, and the cut at $272,743,000$ feet.

From the publication quoted, it appears that in the yeal 1890 therc were $\$ 8$ sawmills in operation in the great pine belt of Georgia, sawing exclusively Longleaf Pine timber. On the basis of lowcst figures cited, the daily cut at these establishments during that year would not fall short of $\mathbf{1 , 6 6 7 , 0 0 0}$ feet, indicating an annul cut of over $400,000,000$ fect.

No statistical returns of the lumber trade previous to $188+$ could be obtained at Savannah, Darien, or Brunswick. The export from the first of these ports averaged about $73,000,000$ feet, board measure, a ycar, showing but slight fuctuation during the period beginning with $188+$ to the close of 1889 , when in the subsequent two years the anuual average increased to $118,000,0,0$ fect, board mcasurc. The cxports from Darien and Brunswick, averaging 82,000,000 and 8., $, 000,000$ fect, respectively, for a similar period of timc, show also but small differences from ono year to another. About 30,000,000 to 33,000,000 feet are rafted dow the Flint and Chattalıonchee livers, to be sawn at Apalachicola. Witl the spread of the sawmills along the railroad liucs in the upper part of the pine region, the shipments of lumber by rail to distant Northern markets incrcascd steadily, until in $\mathbf{1 8 9 2}$ it was found that the production of Longleaf Pine lumber shipped by rail to Northern markets exceerled $60,000,000$ feet. 
Tabular alatement of expurts of Inmber from Sarunnah, Jarien, Brunswick, aul st. Marys to furei!lu and domestic ports und shipments by railroad to inland markets from 1SS3-\$4 10 1S9.3-.\%.

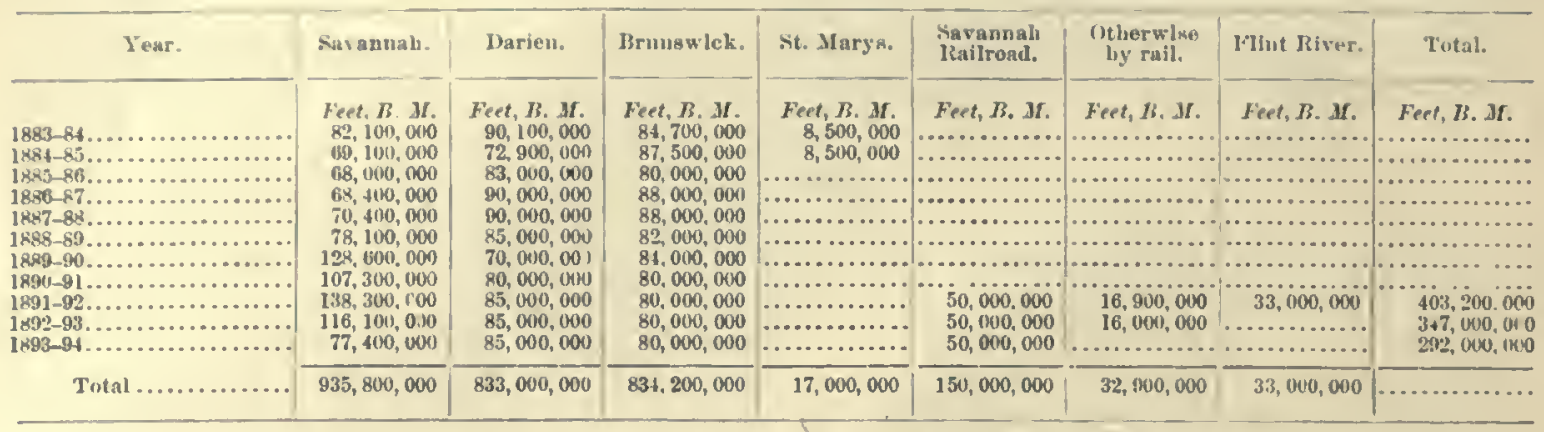

This makes a grand total for the ten years ended 1894 of $2,536,000,000$ feet, board neasure, with an aggregate value, at present export rates (\$11 por 1,000 feet), of at least $\$ 31, i 96,000$.

In the prodnetion of naval stores Georgia takes the leal. By the statements of the census of 1870 , only 3,208 casks of spirits of tnrpentine and 13,840 barrels of rosin, valned at $\$ 95,070$, were produeed during that year in the State. In the eourse of the following ten years this industry progressed steadily and rapidly. In 1888 exports from Savanmah, at present the greatest market in the world for these prodncts, had increased to 168,000 easks of spirits of turpentine and $6 \tilde{5} 4,000$ barrels of rosin, of a total valne of $\$ 3,880,000$.

Statement of exports of naval stores from Savannah during the years 1850-1S24.

\begin{tabular}{|c|c|c|c|c|c|}
\hline Fear. & $\begin{array}{l}\text { Spirita of } \\
\text { turpentine. }\end{array}$ & Irosin. & Fear. & $\begin{array}{l}\text { Spirits of } \\
\text { turpentine. }\end{array}$ & Rosin. \\
\hline 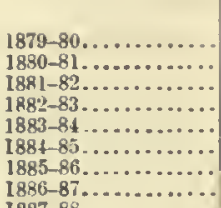 & $\begin{array}{r}\text { Casks. } \\
46,321 \\
54,703 \\
77,059 \\
116,127 \\
129,835 \\
121,028 \\
106,925 \\
140,925\end{array}$ & $\begin{array}{l}\text { Barrels. } \\
\cdot 221,421 \\
282,386 \\
309,834 \\
430,548 \\
5.59,625 \\
401,998 \\
424,490 \\
566,932\end{array}$ & $\begin{array}{l}1888-89 \ldots \ldots \ldots \ldots \\
1889-90 \ldots \ldots \ldots \ldots \\
1890-91 \ldots \ldots \ldots \ldots \\
1891 \ldots \ldots \ldots \ldots \\
1892 \ldots \ldots \ldots \ldots \ldots \\
1893 \ldots \ldots \ldots \ldots \ldots \\
1894 \ldots \ldots \ldots \ldots \ldots\end{array}$ & $\begin{array}{l}\text { Casks. } \\
159,931 \\
181,542 \\
196,227 \\
196,160 \\
234,986 \\
277,617 \\
261,081 \\
\end{array}$ & $\begin{array}{r}\text { Rarrels. } \\
577,990 \\
716,658 \\
770,311 \\
758,418 \\
873,678 \\
1,032,198 \\
957,027\end{array}$ \\
\hline $1887-88 \ldots \ldots \ldots \ldots$ & 168,834 & 654,286 & Total. & $2,475,297$ & $9,637,830$ \\
\hline
\end{tabular}

Valued at $\$ 49,401,031$.

The lighest priees for these stores in Savannah were obtained in 1880 , with $\$ 19.50$ per cask of 50 gallons for spirits of turpentine and 82.25 per barrel of rosin of 280 pounds gross; and the lowest in 1887-88, with the price of spirits of turpentine at $\$ 14.25$ per eask and $\$ 1.40$ per barrel of rosin. On close scrutiny of the prices rnling at Wilmington, for the eleven years after 1880 the priee of a eask of spirits of turpentine averaged $\$$ IS and of a banrel of rosin $\$ 1.90$, lowest grades of the latter exeluded.

Floridn.-That part of the State between the Snwanee River and the Atlantic Const, as far sontlı as St. Angustine, ean be considered as part of the Atlantic pine region, and eover's an area of about 4,700 square iniles. In the basin of the St. Johns River a large part of the lancl lias been devoted to the cultivation of the eitrus fruits. The principal sites of the mannfactnre of lnmber in this seetion of the State are Ellaville, in Madison Connty, on the Suwanee River, and Jacksonville. The supplies onee existing along the Cedar Keys and Fernandina Railroat are at present well.nigh exlausted. Sonth of St. Angustine the Ionglenf l'ine is less enmmon and in general inferior in size. The timber on the extensive flat woods to the liverglades, covered with the Saw Palnetto, is sunted and the forests are very open, and in the more fertile soils Longleaf Pine is largely replaced by Cuban Pine. In the central section of the peninsula, with its unmerous lakes, the Longleaf l'ine is often associated with the Sand Pine (Pinus clausa), and lard roods prevail on the upland hummock lands.

THE MARITIN PINE IBLT OF THE FASTFRY GULF REGION.

From the banks of the Snwanee River to the mplands bordering the alluvial lands of the Mississippi this pine belt, varying from 90 to 195 miles in willtr, eovers an area ronghly estimated 
at a little over 40,000 square miles. It presents no material differences from the Atlantic region, of which it is a direct continuation, being similar to it in both soil and climate.

This eastern Gulf region is mnsurpassed in the advantages it offers for the developunent of the iurlustries baséd on the products of the pinc forests. Its genial clinate throughont the year permits the uninterrupted cxploitation of its abmulant resources of resinous products and of timber of the best quality. The finc liarbors and safe roalsteads on the Gulf Coast are reached by navigable, rivers, which, with their tributaries, cross the lower division in every dircetion, and give ready and elicap trausportation to its ports, while great railway lines afford easy communication with inland markets. This region thus presents indncements s'arecly fonnd elsewhere for the investment of capital and labor in the development of the resources of its forests.

It is impossible to arrive at anything like an accurate cstimate of the amount of timber standing at prescnt, or of the rate of its consumption, since in the returns of the annual lumber product that needed for honc consumption has not been included.

Testern Floridn.-Placing the eastern limit of that part of Florida to be considered as belonging to the Gnlf pine region at the lower course of the Suwanec River, the area included comprises abont 7,200 square miles, exchusive of the swamps and marshes of the coast. The forests of Longleaf Pine form a narrow strip along the course of the Suwance River and along the coast to the Appalachicola River, covering abont 1,280,000 acres. At their northern limit they merge into the oak and hickory uplands of midalle Florida. Along the coast they are surrounded by marshes and swamps, rendering them difficult of access, consequently they have remained nutonched. The sume may be said of the pine forests between the Appalachicola and the Choctawhatehce rivers. These have becn invaled to some cxtcnt along the banks of the latter river to supply the small mills situated on the bay of the same name.

The pine lands of westcrn Florida rise slowly above the coastal plain and form a vast expanse of slightly undulating surfice. Those surrounding Perdido, Pensacola, Blackwater, and Nary St. Galves Bay, the oldest sites of active lumber industry in the Gulf region, were stripped of their valnable timber more than thirty years ago, and since that time have been cut over again.

The largest tracts of finely timbered virgin forests of Longleaf Pine are found in the undulating uplands from the Perdido and Escambia rivers along the Alabama State line to the banks of the Cloctawhatchee River. East of this river, in the same dircetion, wherc the younger Tertiary strata make their appearance, Longleaf Pine becomes associated with hard woods, with soutlern Spruce Pine added in the valleys. Since the opening of the Pensacola and Atlantic Railroad considerable quantitics of sawn square timber find their way to Pensacola from these remotcr forests.

A large portion of the timber supplicd to the mills along the coast having been derived from Alabama, it is impossible to arrive at an exact estimate of the products of the forest of western Florida.

Statement of export of hewn square timber, sawn square timber, aud lumber to foveign and domestio ports from Pensacola, Fla., from $1879-80$ to $189,93$.

[From Hyer \& Bro.'s annual circulars.]

\begin{tabular}{|c|c|c|c|}
\hline Year. & $\begin{array}{l}\text { Square hewu } \\
\text { timber. }\end{array}$ & $\begin{array}{l}\text { Square sawn } \\
\text { timber and } \\
\text { lumber. }\end{array}$ & Total. \\
\hline 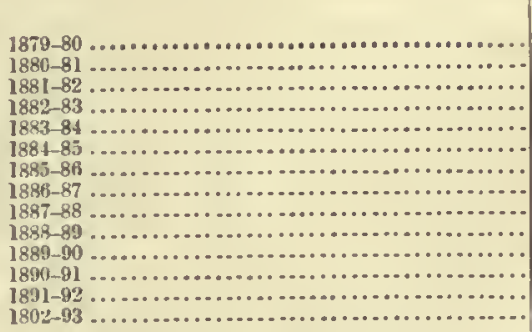 & $\begin{array}{r}\text { Cubic feet. } \\
2,180,000 \\
4,603,000 \\
5,479,650 \\
2,169,001 \\
2,031.000 \\
1,627,000 \\
1,700,100 \\
1,030,000 \\
1,283,000 \\
1,574,000 \\
1,367,000 \\
1,550,133 \\
1,488,272 \\
1,449,910\end{array}$ & $\begin{array}{l}\text { Feet, } B . M . \\
176,000,000 \\
209,098,000 \\
164,305,000 \\
188,100,000 \\
194,890,000 \\
195,576,000 \\
215,750,600 \\
231,884,600 \\
238,299,400 \\
310,255,000 \\
276,587,000 \\
254,125,000 \\
325,081,000 \\
252,808,000\end{array}$ & $\begin{array}{r}\text { Feet, } B, \boldsymbol{H} \text {. } \\
202,000,000 \\
264,000,000 \\
230,000,000 \\
211,388,000 \\
219,286,000 \\
21,131000 \\
228,590,000 \\
245,221,000 \\
253,699,000 \\
329,153,000 \\
292,991,000 \\
271,728,800 \\
294,958,700 \\
270,208,000\end{array}$ \\
\hline Total. & & & $3,534,352,300$ \\
\hline
\end{tabular}

In the shipment of these prodnets in 188.5 , valned at $82,305,500$, there were 471 vessels engaged,

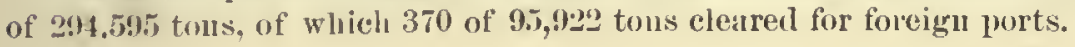


During these fourteen years the priee of square timber and lumber taken in the aggregate averaged abont $\$ 12.50$ per 1,000 feet, board measure. On this basis the valne of the mill products for these parts of the forests of Longleaf Pine anounterl to $\$ 3,155,670$ a year.

For the past forty years, luring wlieh the lands of the peninsular part and in middle Florida have passerl mostly into possession of small proprietors, no naval stores have been produeed in this section. In western Florida, however, in proximity to the Louisville and Nashville and Pensacola railroads, large areas have been subjeeted to the tapping of the trees, and the forests elose to these railroads having been exhansted, the products of the turpentine stills are hanled for a distanee often exeeding 10 miles and find their market mostly at Mobile.

Alabama.-Oring to the diversity in geologienl eonditions and in topographieal featnres prevailing in this State, the distribution of the Longleaf Pine presents within its borders peenliarities not found elsewhere. It appears in three separate regions-the maritine pine belt, the central pine belt, and the pine forests of the Coosa Basin and other ontlying forests in nortl Alabama.

The eoast pine belt extends from the Gulf shore inland for a distance of from 90 to 100 miles, and has been estimatel to eover abont 13,750 square miles, or $8,800,000$ acres, ontside of the swamps and flatwoods of the eoast plain. The latter, perfectly level or rising in gentle swells above the tidewater marshes, is almost eompletely stripperl of its original timber growth. After its removal the Longleaf Pine lias largely been replaced by Cuban Pine.

The rolling pine uplands rise to a lieight of from 200 to 350 feet above the lowlands of the coast. In the lower part of this pine belt, where the sandy and gravelly deposits of the latest tertiary strata prevail, the Longleaf Pine forms pure forests, witl the exeeption of the narrow strips of hardwood timber bordering the water eourses. This lower division covers abont $4,250,000$ acres. In the extent and quality of their timber resontees these Longleaf Pine forests ean be eonsidered ecpual to those found in the adjoining parts of Florida and in Mississippi, and unsurpassed by those of the most favored sections of the A tlantic pine forest.

The following neasurements of trees felled nen' Wallace, Eseambia Comity, in eollecting the material for the United States timber tests, will serve to represent fairly the quality of the merehantable timber in eonformity witl the standard in vogne at the mills in 18.80, and the relation of age to growth:

Meusurementx of fire trees.

\begin{tabular}{|c|c|c|c|c|c|c|}
\hline Number of tree. & $\begin{array}{c}\text { Diameter, } \\
\text { breast } \\
\text { hfgh. }\end{array}$ & $\begin{array}{l}\text { Total } \\
\text { height. }\end{array}$ & $\begin{array}{l}\text { Rings on } \\
\text { stump. }\end{array}$ & $\begin{array}{l}\text { Dlameter } \\
\text { below } \\
\text { crown. }\end{array}$ & $\begin{array}{l}\text { Mean diara- } \\
\text { eter of } \\
\text { timber. }\end{array}$ & $\begin{array}{l}\text { Length of } \\
\text { timber tree } \\
\text { of limb. } \\
\text { knots. }\end{array}$ \\
\hline 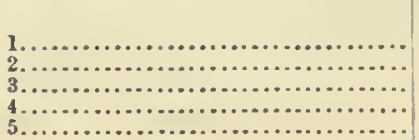 & $\begin{array}{r}\text { Inches. } \\
26 \\
19 \\
16 \\
18 \\
19\end{array}$ & $\begin{array}{l}\text { Feet. } \\
106 \\
111 \\
111 \\
113 \\
113\end{array}$ & $\begin{array}{l}216 \\
189 \\
183 \\
196 \\
182\end{array}$ & $\begin{array}{r}\text { Tnehes. } \\
18 \\
14 \\
12 \\
15 \\
13\end{array}$ & $\begin{array}{r}\text { Inehes. } \\
22 \\
16 \\
14 \\
17 \\
16\end{array}$ & $\begin{array}{r}\text { Feet. } \\
50 \\
60 \\
45 \\
50 \\
50\end{array}$ \\
\hline A verage................... & 19.6 & 111 & 193 & 14.5 & 17 & 51 \\
\hline
\end{tabular}

At a lumber eamp near Lumberton, in Washington Connty, 9 timber trees were measured showing on the average a mean diameter of 17 inehes, the elear stieks averaging 40 feet in length.

Upon 1 acre, seleeted at random in the untonehed forests nortl of Springhill, Mobile Comnty, very open and free from smaller trees or undergrowth, 1 (i trees were eounted above 16 inehes in diameter at breast high, nanely, 2 trees 23 inehes in diameter at breast high, estimated length of timber, 40 feet; 2 trees 20 inehes in diameter at breast high, estimated lengtl of timber, 40 feet; 12 trees 16 to 18 inehes in diameter at breast high, estimated length of timber, 3i; feet; whieh in the aggregate would yield abont 5,000 feet, board measure.

Upon another aere plat of the same quarter seetion 64 trees above 12 inehes in dianeter at brenst high were found; of these 2 trees measured 20 inehes in dianeter at breast high, estimated length of timber, 40 feet; 26 trees measured 17 inches in diameter at loreast high, estimated length of timber, 36 feet; 36 trees measured 13 inehes in diameter at breast ligh, estimated length of timber, 24 foet. 
Upon a third plat exeeptionally lieavily timbered, 45 trees were counted, of whieh 5 trees were 25 inches in diameter at breast high, the elear timber averaging 50 feet in length; 12 trees 22 inehes iu diameter at breast high, length of timber 50 feet, and 28 trees 16 to 18 inehes in dianeter, average length of timber estimated at 30 feet. Such a stand would indieate a yield of uerehantable timber of at least $\mathbf{1 5 , 0 0 0}$ feet, board measure, to the acre. All over this lower division boggy traets are frequently met with, in which the sour, black soil is covered with sphagnum, or bog moss; these support only a few seattered pines. On many of the steeper ridgcs the soil is pure sand and the pine growth is small and inferior, being largely replaced by Barren Oak, Sparkleberry, and the evergreen heather.like shrub Ccratiola cricoides.

In this lower division of the maritinc pine belt the manufacture of lumber and the produetion of naval stores is carried on most actively. These products fiud their outlet ehiefly at Mobile, while more than one-third of the lumber exported from Pensacola (to the amount of at least 100,000,000 feet aunually for the past few years) is also derived from this division. In the upper lialf of the inatitime pine belt, with the appearauce of the outerops of limestones and limy marls of the Lower Tertiary (Eoeene) formation, the conntry becomes nore broken, with steeper lills and wider valleys, and a change iu the character of the flora takes place, partieularly manifest in the nature and distribution of the tree growth. In the fertile valleys and on the lower flanks of the lills broad-leaved trees, mostly Post Oak, Blaek Oak, Moekeruut, Bitternut, Pignut, and Magnolia prevail, interspersed with Shortleaf Pine, Loblolly Pine, and Red Cedar-the Longleaf Pine oeeupying sporadie patehes of drifted sands and pebbles. On the ster.p and frequently wide ridges eapped by these deposits, and on the rugged hills of the buhrstone and flinty eherts this tree forms the principal growth, and is in the openings more or less associated with broad-leaved trees. From this eominingling of cone-bearing and deeiduous trees and the alternations of pine forest and onk woods, this upper division has beeu desiguated as the region of mixed growth, whiel at a rongh estimate cau be said to eover about 5,000 square miles.

In the deep soil of light loam and strong loamy sands the Longleat' Pine attaius a splendid growth and the number of large trees on a given area is greater than found in the lower division. The following measurements of 5 trees felled for test logs fiirly represent the average dimensions of the timber from these hills in the vieinity of 'Thomasville, Clarke County:

Measurements of five trees.

\begin{tabular}{|c|c|c|c|c|c|c|}
\hline Number of tree. & $\begin{array}{l}\text { Rings in } \\
\text { stump. }\end{array}$ & $\begin{array}{c}\text { Diameter } \\
\text { breast } \\
\text { ligh. }\end{array}$ & $\begin{array}{l}\text { Dianneter } \\
\text { below } \\
\text { crown, or } \\
\text { toll end } \\
\text { of tiruber. }\end{array}$ & $\begin{array}{l}\text { Meran } \\
\text { ol tiameter } \\
\text { of timer. }\end{array}$ & $\begin{array}{l}\text { Lungth } \\
\text { of timber. }\end{array}$ & $\begin{array}{l}\text { Total } \\
\text { lieight of } \\
\text { tree. }\end{array}$ \\
\hline 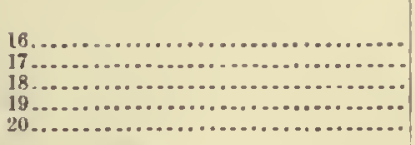 & $\begin{array}{l}202 \\
103 \\
210 \\
160 \\
110\end{array}$ & $\begin{array}{c}\text { Inches. } \\
20 \\
21 \\
22 \\
20 \\
17\end{array}$ & $\begin{array}{c}\text { Inches. } \\
15 \\
14 \\
16 \\
19 \\
13\end{array}$ & $\begin{array}{c}\text { Inches. } \\
18 \\
17 \\
19 \\
22 \\
15\end{array}$ & $\begin{array}{r}\text { Fret. } \\
45 \\
40 \\
40 \\
40 \\
30\end{array}$ & $\begin{array}{r}\text { Feef. } \\
108 \\
115 \\
110 \\
111 \\
92\end{array}$ \\
\hline Arerage ....................... & 171 & 21.2 & 15.4 & 18.2 & 39 & 100.2 \\
\hline
\end{tabular}

Many of the trees of larger size were found affeeted by wind-shake in the direetion of the rings of growth (ring-shake), in many instances impairing greatly the quality of the timber. The forests on these hills are open, with a eoruparatively small $11 m$ mer of young trees. Upon 1 acre selecterl at randon 46 trees were eounted; of this uumber were found 4 trees of a diameter of 25 inches breast ligh, and the length of timber about 40 feet; 10 trees of a dianeter of 22 inclies breast high, and the length of timber about 36 feet; 26 trees of a diameter of 18 inches breast ligh, and the length of timber about 30 feet; 6 trees of a diameter of 15 inches breast high, and the length of timber abont 25 feet.

On the average each one of these trees wonld yield about 4110 to 450 feet, board measure. On another acre 44 trees were found differing in their average dimension bnt sliglitly from the above, and indieating a yield between 18,000 and 19,000 feet of lumber to the aere. In this upper part of the eoust pine belt lumbering and turpentine oreharding have not developed to any great extent, owiug to its inaccessibility. However, where railroads traverse the seetion, the manufacture of 
lumber is earried on extensively, the output going to Northern markets. Mneh of the heavy hewn timber that is exported from Mobile and Pensaeola is furnisherl by this section.

In eollecting the statisties on the lnmbering interests in the maritime pine belt of Alabama the infurmation kindly furnished by firms engaged in the sawmill business or the lmuber trade lias chietly been relied npon. The anmal prodnction was arrived at by multiplying the average daily ontput reported ly 200, the assumed mumber of working days of the year. From these data it appears that during the year 1893 the daily ontput of the 25 points repolted from anounted in the aggregate to about 768,000 feet, or to $192,000,000$ feet, board measure, for the year. This figure can be said to represent the average of the annuml production for the past three years. To this anount, at a low estimate, $85,000,000$ feet of ronnd timber are to le adder, ent in Alabana and sawn in western Florida, inelnding the hewn square timher shipperl from the State to Pensacola, thus swelling the present annual produetion of lumber and square timber in the maritine pine belt of Alabama to a total of about $277,000,000$ feet, board measure. The statement of the ammal exports of these produets from Mobile by water and by rail for the past fourteen years will aptly illustrate the steady inerease of the lumbering interests during this period.

Statement of exports of square timber, hewn and sam, and of lumber shipped from Mobile to foreign and domestic ports from the year 1879-80 to the eud of the year 1894.

\begin{tabular}{|c|c|c|c|c|}
\hline Year. & $\begin{array}{l}\text { Squnare } \\
\text { timber, lown } \\
\text { and sawn. }\end{array}$ & L.umber. & $\begin{array}{l}\text { Total lumber } \\
\text { and square } \\
\text { timber. }\end{array}$ & Tnlue. \\
\hline 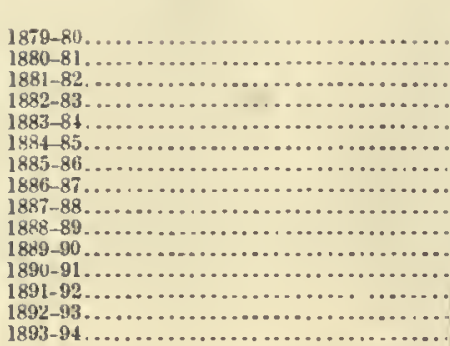 & $\begin{array}{r}\text { Cubie feet. } \\
745,000 \\
1,725,000 \\
1,074,000 \\
1,052,804 \\
3,810,714 \\
3,121,794 \\
2,973,206 \\
1.863,259 \\
2,450,257 \\
3,049,440 \\
3,814,087 \\
3,592,924 \\
5,072,088 \\
5,377,009 \\
4,147,825\end{array}$ & $\begin{array}{r}\text { Feet, }, \boldsymbol{B} . \mathcal{H} . \\
13,572,000 \\
18,161,000 \\
32,236,000 \\
26,753,843 \\
22,251,000 \\
22,256,000 \\
21,433,500 \\
29,346,000 \\
29,257,000 \\
48,284,000 \\
52,879,000 \\
50,892,000 \\
61,865,805 \\
79,304,565 \\
67,209,745\end{array}$ & $\begin{array}{r}\text { Feet, } \boldsymbol{B}, \boldsymbol{M} \text {. } \\
22,525,000 \\
38,872,000 \\
53,350,000 \\
46,588,000 \\
67,078,000 \\
59,945,000 \\
50,580,000 \\
60,723,000 \\
59,740,000 \\
100,000,000 \\
111,659,810 \\
122,1000,000 \\
141,793,700 \\
162,666,7100 \\
126,684,500\end{array}$ & $\begin{array}{r}\$ 280,825 \\
400,348 \\
710,012 \\
582,000 \\
801,699 \\
636,953 \\
-588,148 \\
641,215 \\
677,804 \\
1,081,828 \\
1.201,934 \\
1,415,000 \\
1,695,000 \\
1,590,900 \\
1,270,600\end{array}$ \\
\hline
\end{tabular}

The first statement of the produetion of naval stores in Alabamat is that reported to the census of 1850 , mentioned in that year as of a valne of $\$ 17,800$. In 1870 the prodnction had increased to 8,200 easks of spirits of turpentine and 53,175 barrels of rosin, valued at $\$ 280,203$. In 1873 the reeeipts in the market of Mobile had fully doubled, amounting to nearly 20,000 casks of spirits of. turpentine and to from 75,000 to 100,000 barrels of rosin, besides 1,000 barrels of tar and pitel, of a total value of $\$ 750,000$. The largest produetion was reaehed in $18 i 5$, when the receipts reaehed a value of $\$ 1,200,000$, up to the present only approxinnated in 1853 with 43,870 casks of spirits of turpentine and 200,025 barrels of rosin, valned at $\$ 1,109,760$. Sinee 1888 a steady decliue in the reeeipts of these prodnets lias taken plaee, dne to the exhanstion of the supplies near the commer. eial highways.

Table of exports of naval stores from Mobile during the period of 1850-1894.

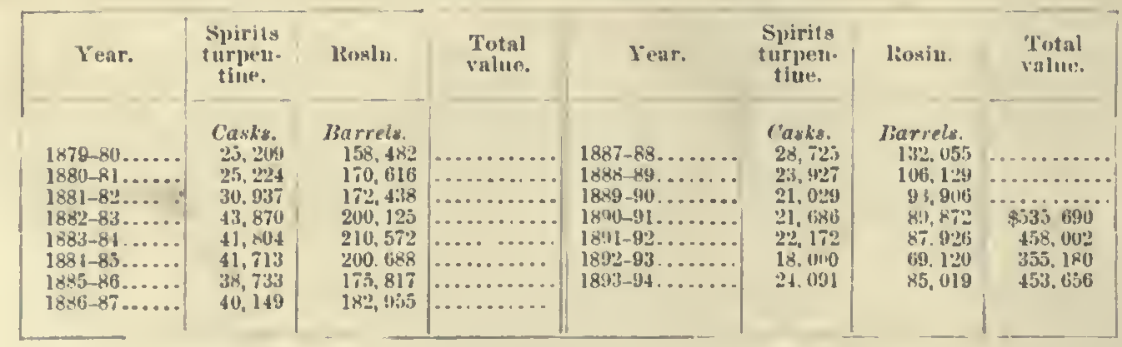


TUE CENTJAL PINE JBELT OF ALA IBAMA.

The middle portion of the State is erossed from its eastern boundary nearly to its western, with a deeirled northern trend along the western border, by a belt of drifted loamy sands, pebbles, and light loans corered in the eastern and central parts with an almost eontinuous forest of Long. leaf Pine, interrupted only by strips of lard wood which oecupy the bottom lands. In its eastern extent the Longleaf Pine becomes associated with upland oaks, hiekories, and Shortleaf Pine, the Longleaf Pine being entircly replaeed in the northern extension of this belt by the latter species.

This region of gravelly hills, as it is designated in the agricultural reports, ${ }^{1}$ is 200 miles in length, 5 to $3 \bar{j}$ miles in width, and extends over about 2,000 square miles. In the sections wliere the forest consists almost cxclusively of Longleaf Pine the stand of timber is heavy and of fine quality. Operators elaim for these timber lands a yield of from 5,000 to 6,000 feet of uerehantable timber to the acre, excluding all trees under 12 inehes dianeter.

Ever since the opening of the great railroad lines leading to Northern markets the manufacture of lumber in this central pine belt has been carried on with unabated activity. In 1880 not less than $80,000,000$ feet, board measure, were transported by the Louisville aud Nashville Railroad alone, mostly to the great Northwestern eenters of commerce. In 1886 the produetion deelined to $50,000,000$ feet. At present most of the older mill sites have been abandoned and a few new ones established in other localities. Colouel Wadsworth reports 12 mills in operation loeated along the Louisville and Nashville Railroad, with an output of a little over 40,000,000 feet a year on the a verage of the past few years. To this is to be added the production of the few uills on the Mobile and Birmingham Railroad, which will increase the present production in the eentral pine belt to about $50,000,000$ feet a year.

THE FORFSTS OF LONGLEAF PINE IN NORTH ALABAMA.

Forests of Longleaf Pine prevail with more or less interruption in the basin of the Coosa River, prineipally on the beds of flinty pebbles and light, sandy loam which follow the upper eourse of the river from the base of the Lookout Mountain range near Gadsden to a short distanee beyond the State line in Floyd County, Ga., where the Longleaf Pine finds its uortlern limit in about $34^{\circ}$ north latitucle, at an elevation above the sea of abont 600 feet. With the reappearance of the above deposits south of Calloun County the pine forests extend on the eastern side of the valley south to Clnildersburg. On the isolated ridges of old Silurian sandstone (Potsdam), and the met. amorphic region adjoining, the Lingleaf Pine is seattered and stunted and ascends to an eleva. tion of nearly 2,000 feet above the sea. In proximity to the mincral region the rugged hills and inountain sides lave been eompletely denuded, the pine having been ent for eharcoal to supply the blast furnaces. In the valleys the forests of Iongleaf Pine are of average density and the timber is considered of exeellent quality, particularly in the northern part of the valley in Etowah and Cherokee eounties. On the lower lills the timber is less abundant and somewhat inferior in size. The ineasurements of five trees felled in the lills near Renfroe, Talladega County, can be said to fairly represent the average quality of this pine timber. The mndergrowth in the open forest eovering the low ridges and the narrow valleys is dense, consisting of Blackjack, Spanish Oak, Pignut, and Bitternut Hickory.

Measurements of fire trees.

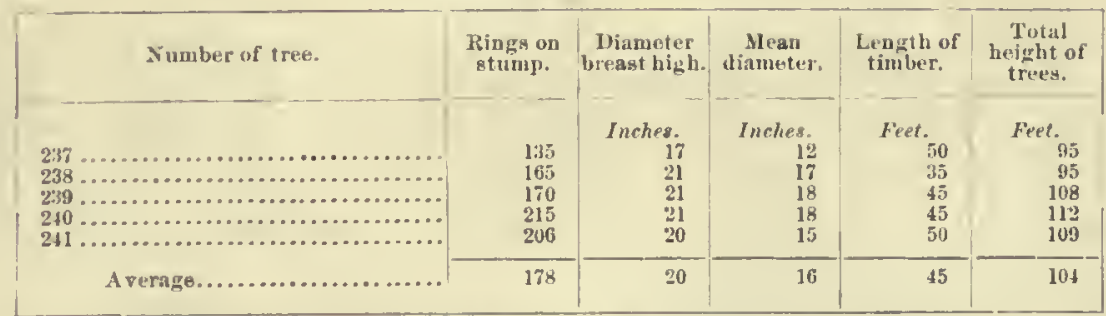

4F. A. Smitb: Agricultural Resources of Alabama, Vol. V. Reports of Geological Survey of Alabama. 
The extinetion of Longleaf Pine in the forests of north Alabama, as far as economie value is coneerned, appears to be certain. The dense undergrowth of deeiduons trees suppresses completely the second growth of the Longleaf Pine in the elosed forest as well as in the openings. On the unountain slopes a young pine is rarely seen, no tree being left to serve for the future alissemination of the species, and the few seedlings sporadically springing up are invariably destroyed by the filing of the lierbage one year after another.

The output of the mills at Gadsden and the mills in Talladega Comnty along the Birminglinu and Atlantie Railroad eombined appears scareely to exeed 50,000,000 feet, board measure, on the average per year. A fine forest of Longleaf I'ine is found in Walker Connty, strictly confinerl within an isolated patch of silicious pebbles and sands, said to eover about 60,000 aeres. Distant about 10 miles from the nearest railroad this forest has been but slightly invaded, only to supply a small local demand.

Summary slatement of shipments of lumber and square timber from chief centers of production in Allabema dluring the year 1893.

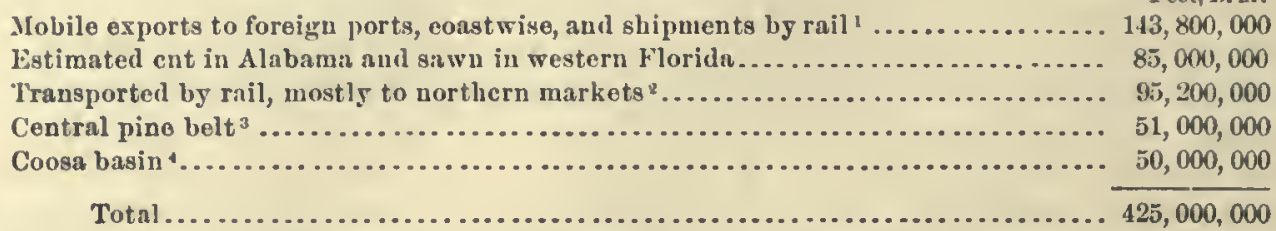

Mississippi.-What has been said of the forests of the maritime pine belt in Alabama applies in general to the same region in Mississippi. The eoastal plain above the extensive grassy marshes lining the seashore and the wide estuaries of the streams covers a larger area, being from 10 to 20 miles in width and embraeing, at a rough estimate, abont 728,000 acres of the 16,410 square miles within the limits of the pine belt. The broad, scarcely pereeptible swells, with a soil of simly loam and loamy sand, were originally well timbered, the widely spreading depressions with soil of fine, compacted sand, poorly drained, bearing a sparse and inferior timber growtl. The timber produced on these flat woods, or "pine meadows," as they are aptly ealled in the adjoining section of A labama, being of slow growth, is liard and of fine grain, frequently with the fibers of the yonnger wood eontorted and of varied tints of eolor. 'This so-ealled curled pine is snseeptible of high finislı and is much appreeinted for fine cabinet work. There is eomparatively little valuable timber left in this coastal plain. The remainder serves largely for the making of ehareoal and cord wood for the New Orleans market.

The rolling pine lands, rising suddenly above the plain, almost exelusively eovered by the Long. leaf Pine, eover (ronghly estimated) abont $7,712,000$ aeres. The western limits of these forests are diffieult to define, numerous ontlying traets being found to extend into or even beyond the region of the loany hills. The region of nixed growth, characterizing the upper division of the maritime pine belt in Alabama, enters the State in the shape of a triangle, with the base along the Alabama State line from Bueatunna to Lauderdale aud its apex near Brandon, in Rankin Conty. The generous soil of the arable lands in this region is mostly under enltivation. The forests of Longleaf Pine eovering the steep hills, rather remote from the high roads of conmerce, have been as jet bnt little exploited. Abont 12,000,000 feet, board measure, of lnmber are shiprerl anmally by the way of the Mobile and Ohio Railroad, mostly to Mobile, from this region of mixed growtl.

From the information that eould be obtained, it appears that the cnt of Longleaf Pine timber in this State on the average for the past three years reached between $422,000,000$ and $425,000,000$ feet. The chicf renter of the lumbering industry is located above the Pascagoula River, at Sermton and Mosspoint, where it has made great progress during the past thirteen or fonrteen years. In 1880, 60,000,000 teet, board measure, were shipped to foreign and domestic ports, whieh in the

'Anunal statement of commerce of Mobilo. Mobile livgister, September 1, 1892. Compiled from retums marlo to the Nobilo I3on rd of Trade.

${ }^{2}$ Proulnetion of mills soutlı of Montgomory, ete.

${ }^{3}$ Production of mills on Lonisville aul Nashville Railroasl, north of Montgomery to Calera, by Colonel Wadswo:tb.

'Production of unills on Southeru liailway, north of Selma tu Stanton, by M. IIanson. 
year 1892 had increased to $127,000,000$. Comparatively unch larger increase is noticeable in the shipments by rail to inland markets. By the reports eourteously furnished by the anditor of the Illinois Central Railroad in Chicago, in 1850, 12,000,000 feet, board measure, reaclied Northern markets by this line, which in 1888 liad risen to $62,000,000$, with a falling off in the sneeeding year to $52,000,000$. In $189:$ the shipments increased again to $78,240,000$, and reached in 1893 $181,4: 4,000$ feet, board measure.

With the opening of the New Orleans and Northeastern Railroad, in 1883, the lumbering industry took an active start in the virgin pineries. In 1892 fourteen mills are on record, witl a daily capaeity of not less than 400,000 feet; this amount corresponding fully to the actual output for 1891 as well as 1892. According to Mr. Rieh, of Rielıburg, in consequence of the depression during the year 1893, the output was reduecd about one-half.

The following table of partial data regarding annual shipments, made during the thirteen years ending with 1893, from the chief centers of production shows elearly the eonstant increase of the lumbering industry since the close of the year 1830 :

Tabular statement of lumber shipped anunally by water and by rail from the centers of production in Mississippi, 1879-80, $1892-93$.

\begin{tabular}{|c|c|c|c|c|}
\hline Year. & $\begin{array}{l}\text { P'aseagoula } \\
\text { River. }\end{array}$ & $\begin{array}{l}\text { Jearl livver } \\
\text { Hasin. }\end{array}$ & $\begin{array}{l}\text { New Orleans } \\
\text { and Nortlieast. } \\
\text { eri Railroad. }\end{array}$ & $\begin{array}{l}\text { Illinnis Cen. } \\
\text { tral Railroarl. }\end{array}$ \\
\hline 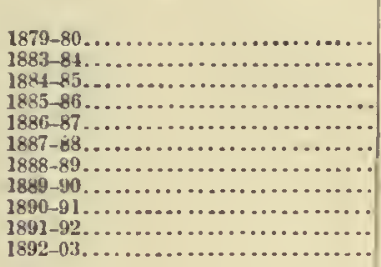 & $\begin{array}{r}\text { Feet, } B . M \\
60,000,000 \\
67,308,000 \\
67,839,000 \\
\ldots \ldots, 000,000 \\
70,0.00 \\
107000,000 \\
119,255,000 \\
170,000,000 \\
127,002.000 \\
\ldots \ldots \ldots . . . . . .\end{array}$ & 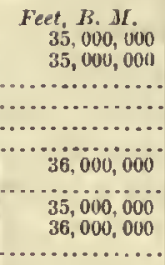 & 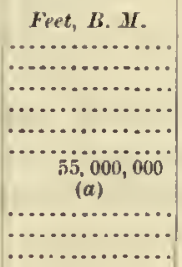 & $\begin{array}{r}\text { Fret, } 13 ., M \text {. } \\
12,000,000 \\
28,000,000 \\
36,000,000 \\
30,000,000 \\
40,000,000 \\
62,000,000 \\
52,001,000 \\
64,000,000 \\
7 ., 2 \ldots, \ldots 00 \\
78,240,000 \\
181,424,000\end{array}$ \\
\hline
\end{tabular}

a From $60,000,000$ to $90,000,000$.

RECAPITULATION FOR 1891-92.

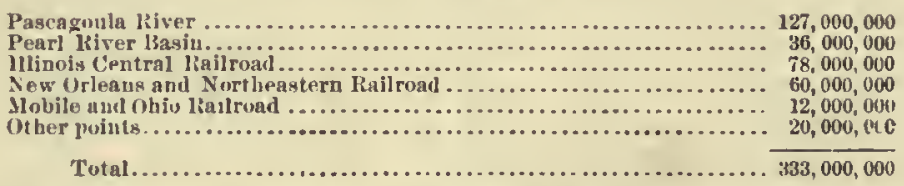

From this amount are to be deducted abont $18,000,000$ fcet of lumber received from Mobile to complete cargoes, and 12,000,000 feet of timber cnt on the western frontier of Alabama and finding an ontlet at Paseagoula by the Escatawpa River, leaving a round $300,000,000$ fect, board measure, for the cut in Mississippi in 1892, against 108,000,000, the cut reported to the census in 1880 .

With the exhaustion of the forests along the P'ascagonla and Eseata wpa rivers and a few points between these streams and the Pearl River, which had been aceomplished before the beginning of 1880 , the naval.store industry remained almost dormant in the State until it began to reeeive a new start by the opening of the New Orleans and Northeastern Railroad. The prodnetion of the distilleries along this road ean be said to average abont 15,000 casks of spirits of turpentine and $i 5,(1)$ barrels of rosin annually since 1890, whiels are mostly disposed of in the New Orlems market.

Eirtern Louisiana.-Forests of Longlcaf Pine eover the upper part of castern Louisiana to the extent of abont 3,880 square miles. Their western limit might be said to follow the Amite River, lut can not be clearly lefined, sinec these forests toward the west pass gradually into the mixed growth of Shortleaf Pinc, oaks, and hickories on the uplands whieh border the bottom lands of the Mississippi River. Slightly undulating that woods cover fully onc-tifth of the area, and, with a somewhat loamy, porous soil, support a better timber growtl than is generally fond in the flat pine barrens of the plain. Owing to their proximity to the coast, these forests lave becn cxtensively invaled. 'The pine hills embrace about 1,619,200 aeres. Their forests luve remained almost intact, their resulrees having been drawn upon only along the Illinois Central Railroad line and the tributaries of the I'earl River. 
I1 1890 seven sawmills were reported, with a daily eapacity, in the aggregate, of about 120,000 feet, board measure. It can sa fely be assumed that their annual output would uot exceed $15,000,000$ feet, board measure. The products of these mills find their unarket chiefly at New Orleans. In former years a consilerable quantity of naval stores was produced in St. Tammany Parish, while at present only a few turpentine orehards are worked in the upper districts.

THE IREGIOY OF LOXGLEAF PINI WEST OF THL MISSISSIPH.

The importance of the.pine forests in the western Gulf region can not be overestinated; considering the development of the immense timberless area beyond their western limit. 'Tlue rapidly inereasing population of the Western plains depends ehiefly upon them for the supply of the material needed to build up the homes of eivilization.

The forests of the Longleaf l'ine west of the Mississippi River, as in regions so fur considered, are geographically limited to the sands and gravels of the latest Tertiary formation. They make their first appearance in Louisiana above the great alluvial plain in the uplands bordering the valley of the Oulehita and follow its course for 50 miles, then extend west, skirting Lake Catahoula and the alluvial lands of the Red River. 'These pine forests to the north of this river cover an area estimated at $1,625,000$ aeres, extending northward for a distance averaging 55 iniles. Toward their northern linit the forests pass gradually into a mixed growth of deeiduous trees and Shortleaf Pine. In the center of this region the pine ridges alternate with tracts of White Oak and Hiekory. Tending toward the Red River, the pure forest of Longleaf Pine whieh covers the mululating nplands is unbroken and has up to the present been but slightly invaded by the ax. On the low hills of this northern division of the pine belt of northwestern Lonisiana the forests are somewhat open, and are composed of trees of the first order as regards their dinensions, the well-drained, warm, and deep soil of sandy loam being highly farorable to their development. This fact is clearly shown in the following statement of the ages and dimensions of six trees felled for test logs:

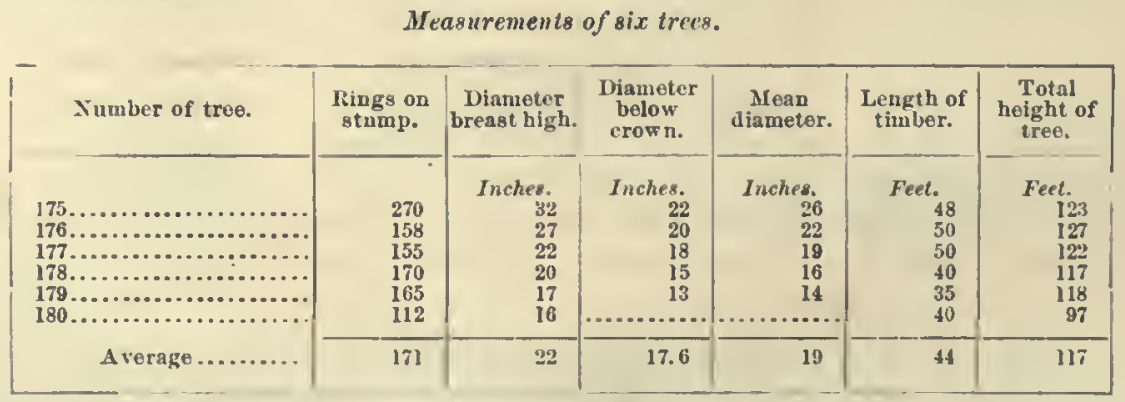

Upon 1 acre of the same plat, with the timber standing rather above the average, 38 trees were fonnd. Of these there were 14 of 24 inehes (kiameter at breast high, estimated length of timber, 45 feet; 6 of 19 inches diameter at breast high, estimated lengtl of timber, 40 feet; 9 of 17 inehes diameter at breast high, estimated length of timber, 35 feet; 9 of 13 inches diametur at breast high, estimated length of timber, 30 feet.

In the opinion of experts, the average yield of 1 aere of these pine lands at a fair estimate is not less than 6,000 feet, board measure.

Aceording to the statements of Mr. Sues, at Levins Station, 56,000,000 feet, board measure, were shipped, in 1892, from the mills of this section.

Soutl of the lied River botton the forests of Longleaf P'ine continue unbroken to the Sabine liver and south to the treeless savamins of the eoast in Caleasien Parish, their eastern boundary parallel with the eastern boundary of that parish. lionghly estimated, these forests cover an area of abont 2,665,000 acres. From the marshy lowlands of the coast to the upper tributaries of the Caleasien River, up to Hickory and Beckwith creeks, the country is poorly drained, almost perfectly level, with a highly retentive and somewhat impervions clay subsoil. In consequence, these pine flats are, for the greater part of the year, more or less covered with water. These low, wet pine forests were stripped some years ago of all their merehantalole timber, and only a comparatively small number of trees of less than 12 inches in diameter were left standing. On 
these abandoned timber lands a young pine is rarely seen, the seeds shed in the fall being apt to rot in the water-soaked soil, or, if they happeu to germinate, the seedlings are drowned during the winter rains. On the lands rising gently above the flat woods, with the ridges still low and wide and often more or less imperfeetly drained, Longleaf Pine is found of an exeeedingly fine growtl. The trees in the deuse forest are tall and slender, and their timber is equaled only by the timber of the same class growing in the valley of the Neches River, in Texas.

The following nueasurements of five trees felled for test logs in the forests in the upper part of Caleasieu Parish, between Hickory and Beckwith ereeks, will serve as a fair representation of the timber growth on these low, broad ridges:

Measurements of five trees.

\begin{tabular}{|c|c|c|c|c|c|c|}
\hline Number of tree. & $\begin{array}{l}\text { Rings on } \\
\text { stump. }\end{array}$ & $\begin{array}{c}\text { Diameter } \\
\text { hreast high. }\end{array}$ & $\begin{array}{l}\text { Diameter } \\
\text { below } \\
\text { crown. }\end{array}$ & $\begin{array}{c}\text { Mean } \\
\text { diameter. }\end{array}$ & $\begin{array}{l}\text { Leugth of } \\
\text { timber. }\end{array}$ & $\begin{array}{l}\text { Total } \\
\text { beigbt of } \\
\text { tree. }\end{array}$ \\
\hline 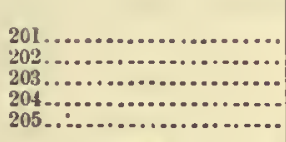 & $\begin{array}{l}196 \\
195 \\
190 \\
180 \\
167\end{array}$ & $\begin{array}{r}\text { Inches. } \\
28 \\
23 \\
21 \\
19 \\
16\end{array}$ & $\begin{array}{r}\text { Inches. } \\
23 \\
16 \\
14 \\
15 \\
13\end{array}$ & $\begin{array}{r}\text { Inches. } \\
24 \\
19 \\
17 \\
17 \\
14\end{array}$ & $\begin{array}{r}\text { Feet. } \\
50 \\
50 \\
40 \\
40 \\
37\end{array}$ & $\begin{array}{l}\text { Feet. } \\
119 \\
127 \\
117 \\
102 \\
127\end{array}$ \\
\hline Arerage........... & 185 & $2 !$ & 16 & 18 & 43 & 118 \\
\hline
\end{tabular}

Upori 1 acre, selected on the baek of a low swell which might be said to represent the averago of the timber standing, 44 trees in all were counted. Of these, 3 trees measured 25 inehes diameter at breast higl, with a length of elear timber estimated at 50 feet; 6 trees measured 23 inches diameter at breast high, with a length of elear timber estimated at 50 feet; 19 trees nreasured 18 inehes diameter at breast high, with a length of clear timber estimated at 40 feet; 14 trees ineasured 14 inches diameter at breast ligh, with a length of elear timber estimated at 36 feet, eorresponding in the aggregate to somewhat over 15,000 feet, board ineasure.

On another acre eonsilered first class, rather level land, the soil fresh to wet thronghout the year, 72 trees were eounted. Of this number, 14 were found 27 inches diameter at breast high, with an estinated length of timber of 50 feet; 5 were found 24 inches diameter at breast high, with an estinated length of timber of 50 feet; 13 were found 23 inches diameter at breast high, with an estimated length of timber of 50 feet; 8 were found 21 inehes diameter at breast.high, with an estimated length of timber of 40 feet; 10 were fouud 20 inches diameter at breast high, with an estimated length of tiuber of 40 feet; 11 were found 18 inelies diameter at breast high, with an estimated length of timber of $\mathbf{4 0}$ feet; 11 were found 18 inehes diameter at breast high, with an estimated length of timber of 36 feet.

Aecording to these figures the timber standing on this aere would amount to not less than $3 \check{3}, 000$ feet, board ineasire.

The ehief site of the lnmber industry of westeru Louisiana is at Lake Charles. Aceording to the information furnished by Mr. George Lock, of Lockport, La., the aunual output of the sawmills in the vicinity of Lake Charles for the years 1892 and 1893 averaged about $151,000,000$ fect, board measure, all shipped West and Northwest. It ean be assmmed that over one-half of the lumber sawn at Orange, iu Texas, is ent on the eastern banks of the Sabine River, which amount lias to be eredited to the cut of Louisiana.

Summary of the production of Longleaf Pine lumber in the State of Lonisiana in 1892.

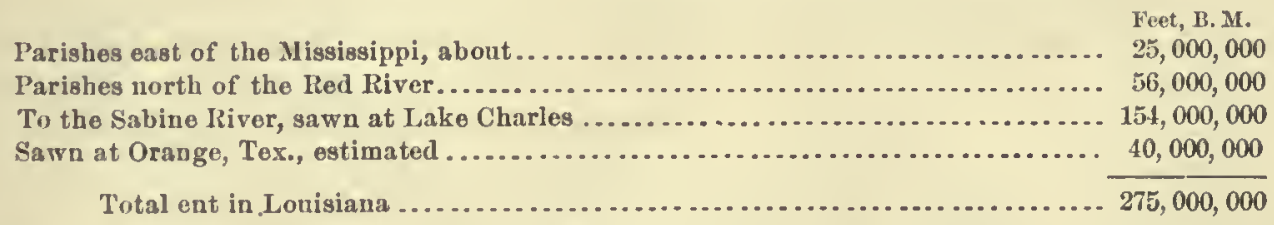

Texas.-The forests of Longleaf Pine extend from the Sabine west to the Triuity River and from the grassy savannas of the coast regiou north to the ceuter of Sabine, San Augustine, and 
Angeliua counties, and include an area of about $2,890,000$ aeres. In amount and quality of the timber these forests are unsurpassel and are only equaled by the forest of the adjoining region in Lonisiana. Toward their sonthern borders the eonntry, like the pine flats of soutluwestern Lonisiana, is perfeetly level and poorly drained, witlı the soil water-soaked for a greater part of the year. These flats have been almost eompletely stripped of their merehantable timber. North of Nona the surface rises gradnally above the water level in broad, low swells, and, being underlaid by strata of stiff loams, is nore or less defieient in drainage. The intervening wide flats are frequently covered with a dense growth of large shrubs and small-sized trees, ensisting of various species of hawthorn (Cratcgus crus-galli, C. vividis, C. mollis, C. berberidifotia), the Deeiduous Holly (Ilex decidha), Dahoon Holly (Ilex caroliniana), Privet (Adelia acuminata), planetrees, and magnolias. These inpenetrable thiekets are common, and often cover many square miles, like the so-called Big Thieket in the lower part of Hardin County, said to be from 10 to 15 miles wide, either way. The growth of Longleaf Pine which eovers the gentle, wide swells, is dense, of fine proportions, and of remarkably rapid development. The average age of five trees felled northwest of Nona, $1 \tilde{5}$ to $2 \tilde{5}$ inches in diameter, is but little over one hundred and tifty years, as the following measurements show:

Measurements of fice trees.

\begin{tabular}{|c|c|c|c|c|c|}
\hline Number of tree. & $\begin{array}{l}\text { Rings on } \\
\text { stump. }\end{array}$ & $\begin{array}{l}\text { Diameter } \\
\text { breast ligh. }\end{array}$ & $\begin{array}{c}\text { Mean } \\
\text { diameter. }\end{array}$ & $\begin{array}{l}\text { Length of } \\
\text { tumber. }\end{array}$ & $\begin{array}{l}\text { Total } \\
\text { helght of } \\
\text { tree. }\end{array}$ \\
\hline 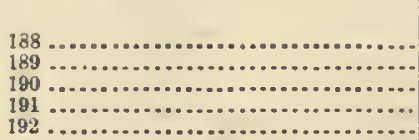 & $\begin{array}{r}240 \\
208 \\
105 \\
113 \\
94\end{array}$ & $\begin{array}{r}\text { Inehes. } \\
26 \\
22 \\
18 \\
21 \\
15 \\
15\end{array}$ & $\begin{array}{r}\text { Inches. } \\
20 \\
19 \\
16 \\
18 \\
12\end{array}$ & $\begin{array}{l}\text { Feet. } \\
40 \\
50 \\
50 \\
45 \\
40\end{array}$ & $\begin{array}{l}\text { Feet. } \\
110 \\
101 \\
113 \\
110 \\
107\end{array}$ \\
\hline Average...... & 152 & 20 & 17 & 45 & 104 \\
\hline
\end{tabular}

In this region, owing to the direct eommunication of several railroad lines with the great centers of trade in the North aud with the treeless plains of the far West, the mannfacture of lumber has made a wonderful progress during the past twelve years. In 1850 the eut of Longleaf Pine in this State lias been estimated at $66,450,000$ feet. From information received from parties engaged in the lumber business, the ent dnring the year 1892 can safely be estimated at 440,000,000 feet. The centers of lnmber production are Orange and Beamont, but a great anount is eut at the mills along the several lines of railway passing through this region.

Output of Longleaf Pine lumber in Texas during the ycar 1892.

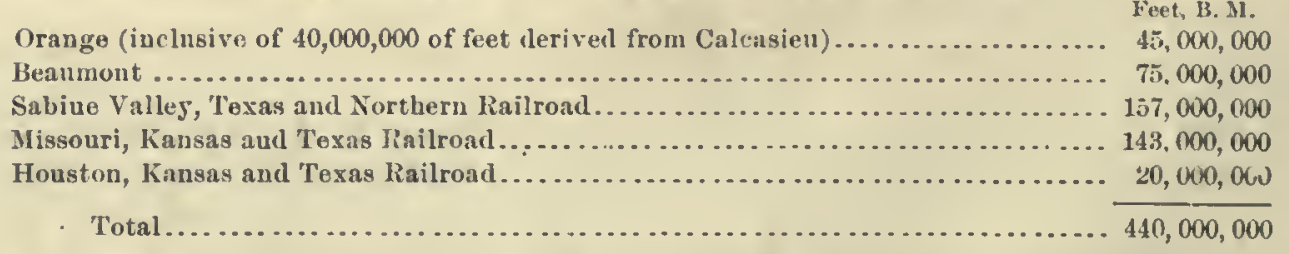

For the renewal of the forests of Longleaf Pine in this region there is as little hope under their present management as in the adjoining region in Louisiana. In this cold, wet soil the seels find but a poor chance for germination, and the surviving plantlets soon suceumb to the sane canse. In the pine flats seedlings are rarely observed among the tall broom sedge grasses (Andropogmu) which, under the influence of light and a damp soil, thrive luxuriantly in the that woods denuded of their timber growth, imparting to them the aspeet of waving meadows or savanuas.

\section{PRODUC'TS.}

VALVT AND USES OF THF, WOOD.

The wood of the Longleaf Pine is harlly surpassed by any of our timber trees of eeonomic importance, and is practically unsurpassed by any nember of its own order in the qualities whieh are required for purposes of eonstruction, thus taking the first place anong its congeners. 
The timber from the damp flat woods of the coastal plain east of the Mississippi River, with a soil of almost pure, finc, closely compacted saud, is of slow growth and gencrally of the finest grain, often exhibiting that irregularity known as "curly pine." Iu the perpetually damp to wet soil of the pine flats in southwestern Louisiana and iu Texas, with a deep retentive subsoil richer in nutritive clements, causing a better and quicker development of the tree, the wond is of a more open grain. Owing to the exccllent qualitics of the wood of Longleaf Pine, its use in the various mechanical arts and industries is as extensive as it is nanifold. Its greatest valne rests in its adaptability for heavy constructions-in naval arehitecture, for masts and spars; in civil engiueering, for the building of bridges, viaducts, trestlework, and for supports in the coustruction of buildings. Large quantities of long and heavy sticks of square timber sawn or liewn for such purposes are shipped to the British ports and to the dockyards of the European continent, with a constantly increasing demand.

In the building of railroad ears, where great strength and elasticity is necded, the timber of Longleaf Pine is preferred to any other. For this purpose sticks from 36 to 42 fcet, 10 by 13 inches, are required, free from blemish.

Enormous quantities of the younger timber of this tree are cut every year to serve for crossties, used by the railroads not only in the pine regions, but in other parts of the country. The demand for these ties forms a constant and increasing draft upon the forest. The ties delivered are, on the average, $8 \frac{1}{2}$ feet long, 9 inches wide, and 7 iuches thick, and inust be all heartwood and free from blemish. The trees selected for this purpose are from 15 to 16 inches in diameter, and preferably ouly the butt cuts are accepted. Ou an average 10 cross-ties are cut from 1 acre, each tie represeuting a log which would make at least 75 superficial feet of linmber. Since such a tie, ready for the roadbed, contaius not more than 50 feet, board measure, it will be readily seen what an euormous waste results from this practice.

On the damp, sandy tracts of the lower South, such ties will last five or six years, and 3,000 ties are needed for 1 inile of road. Hence, for the construction of the 3,240 miles of railroad traversing the forest of Lougleaf Pine east of the Mississippi.River, nearly 10,000,000 ties lave been required, which being rencwed every six years involves an annual cut of $116,000,000$ feet, boarl measure, to which inust be added the amount exported to other regious.

In the Sonthern States, the West Indies, many places on the coast of Mexico, and·Central and Sunth America the lumber of the Longleaf Pine forms the chief, if not the ouly, material in the construction of louses. For similar purposes considerable quantities are of late years shipped to ITorthern markets, East and West, replacing in many cases, at least in parts of the buildings, the lumber of the White Pine, on accont of its increasing scarcity. The fine-grained and "curly" varicties of Longleaf Pine lumber, by their beauty and the high polish of which they are susceptible, begin, of late years, to take a place among the higher-priced kinds of wood for ornamental inside work.

The importance and value of Longleaf Pine lumber as a material for constructious can not be better evidenced than by the fact that little less than 1,500,000,000 feet, board measure, or about one-third of all the lumber inanufactured in the South, is being exported from Southern ports annually to domestic and foreign ports, besides furuishing almost the only material used at home in the construction of dwellings and all kinds of buildings. It also supplies material for furniture, as well as fuel, both in the form of firewood and charcoal, and its exploitation affords the means of subsistence to thousauds.

Lighticood.-Whenever the sapwood of the tree is laid bare copious exudation of resin takes place and the snrrounding wood becomes charged with it. Thus the wood of the trunks of the trees tapped for the extraction of their resin soon becomes eharged with this along the searificd surfice, and, as with the evaporation of water from the dead woorl, the resinification proceeds aud the wood increases in weight and durability. In low, damp places particularly this process takes place more extensively. This resin-charged wood is termed lightwood. The lightwood timber, considered very durable when exposed to alternating conditions of moisture and dryucss, is much preferred for posts, etc. Being highly inflanmable, it serves for torches and kindling, and hence its name. Of late years a protitable industry luas been started to utilize the resinons stumps of abandoned orchards as kindling material by cutting the same close to the ground and then, veneer 
fushion, into long, narrow strips three-fonrths of an inel thiek, which are snbsequently steamed and rolled in small bundles to make a convenient package for shipment. T'lie knots, limbs, rootsparticularly "fat," i. e., highly charged with resin-are nsel in the making of tar.

Chnreoal burning.- Where a market is found the trees left standing, after the removal of the larger timber fit for sawlogs, are burned for clareoal. This industry is carried on to a greater or less extent in the mineral regions to snpply the blast furnaces operated for the unanfacture of elıarconi iron. Large areas of the forests of the Longleaf, covering the hills in north $A$ labama, have been entirely deunded of their tree covering to meet the demands for sueh purpose.

Fuet ralue.-The air-dry wood of the Lougleaf Pine is mueh esteened for fuel; containing but a simall pereentage of ash - not over 0.25 per eent-with a small amount of water, and a deuse and elose fiber, as indicated by its high speeific gravity, its fuel value is neeessarily ligh. Being also casily inflammable, it is preferred where quiek and intense heat is required, as, for instanee, in bakeries, briek kims, potteries, etc., and in the raising of steam for stationary engiues on steam. boats and railroad loeomotives throughout the pine region, where uineral eoal ean not be eheaply obtained.

RESINOUS PRODUCTS OF TIIF LONGLAAF PINE.

It can safely be asserted that annong the trees of the same order there is found no other equally rieh in resiu. The inannfacture of naval stores from the resin of the Longleaf Pine forms one of the most widely developerl industries in the pine forests of the eoast pine belt of the Sontl. ern States, and is scarcely less inportaut than the manufaeture of its lnmber. A full aecouut of these industries will be found in the aeeompanying appendix. Conceruing the mannfaeture of tar, piteh, tar oils, and other prodnets of destrnetive distillation of the rood and of rosin oil, see the Report of the Chief of Forestry, 1892, page 356, ote.

pRODUCTS OHTAINE) FROM TIE LEAVES OF LONGLFAF PINE.

The green leaves of the tree fnruisl by distillation an esseutial oil of balsanie odor elosely resembling spirits of turpentine. The so ealled piue wool is made fiom their eellular tissue, being treated with a strong alkaline solntion at boiling heat, the remaining fiber being eleaned and earded. This pine wool is used in upholstery, and is said to be of value as au antiseptie dressing for wounds: Of late years it is mannfacturel into varions kinds of textile fabrics. One fabrie is a earpet whieh resembles eoeoa matting somewhat, but is elosely woven and is uaturslly of a rieh-brown eolor and very durable. This industry, only reeently established, has already uet such sueeess that the manufaeturers have added twenty nine looms to their work.

\section{NOMENCLATURE AND CLASSIFICATION.}

This tree was first deseribed by Miller in the year 1768 under the unme of Pinus palustris. The youuger Mielıanx snbstitnted for it the more appropriate one of Pinus anstralis, under which name it was deseribed by suceeding writers aud generally knowu to botauists of recent date. To satisfy the law of priority, the name given by Miehaux his recently been dropped and the old one reinstated, in the Catalogne of North Aneriean Forest Trees, ${ }^{1}$ published in the ninth volume of the eeusus reports of 1880 . (See vernaenlar nomenelature iu iutroduetiou.)

BOTANICAL DESCHIPTION AND MOHPHOLOGY.

Leaves three, in a long light-colored sheath; commonly from 9 to 13 (somotimes 14 to 15 ) inches long; of a lright green color and closely set in brusli-like clnsters at the ends of the stont branches. Cones largo, dark tan colored, 6 to sometimes 8 inches long and 2 to $2 \frac{1}{2}$ inches in diameter when closed, 5 to 6 inches when open; scales ahont 2 inches long and one-half to $1 \mathrm{inch}$ wide-rather nuiform in width-somewhat thickened at the ends, and bearing a rather delicate incurved prickle; seed large, slightly triangular, thrce-cighths to seven-sixteenths of an inch long and onefourth of an inch wide; oiten with two or three longitudinal ridges on one face; whitish, with fow or abundant browu specks; wing $1 \frac{1}{2}$ to 2 inches long and of a glossy brownish to deep purple-brown color.

The most conspieuous aun distinguishing feature of this species is the silvery thiek terninal bud, or rather the bud-like clnsters of the yonng leaves inclosed in their finely fringed subtending scales. Its branehes are rough, eovered with the hases of the imbrieated leaf seales, the elongated silvery fringes laving fallen off. 
ROOT, STEM, AND BRANCII SYSTEM.

The Longleaf Pine attains a height averaging 100 feet, rarely exeeeding 110 feet, with a diameter breast high, when fully grown, varying between 20 and 36 inches, rarely more. The tall, straight, very gradually tapering trunk arises from a massive taproot which, in favorable situations, penetrates the soil to a depth of from 12 to 15 feet, and sometimes much morc. It has several stont, comparativcly short lateral roots, which assist the tree in its hold by slanting deeply into the ground, and some of greater length are placed more or less near the surface. Its erown is open and elongated, of irregular shape, about one-half to one-third of its height. The stout limbs are rarely over 20 feet in length, twisted and gnarled and sparingly branched. The trunk is covered with a reddish-brown bark, one-fourth to three-fourths of an inch thick, furrowed thronghout its full length, crossed horizontally by deep fissures, and sealing off in thin, bluish, almost transparent rhombic flakes.

LEAVES AND THEIR MODIFICATIONS.

Like all the pines, this species produces during various stages of its growth seven different modifications of leaves as recognized by botanists, all nore or less specific in character:

(1) Cotyledouary, or seed leaves (first leaves of the embryo), which soon wither and disappear (PI. VII, $a, b)$. (2) Primary leaves succeeding the former immediately on the main axis (PI. VII, $c$ ), which either wither or later on are transformed into, or succeeded by, more or less permanent bracts or scales covering the branches $(\mathrm{Pl} . \mathrm{V}, a)$. (3) The secondary or foliage leaves rising from the buds produced in the axils of the primary lcaves or of the scales by which they are represented (Pl. VII, 1), forming the permanent foliage of the trec, with three leaves in one sheath. (4) The bud scales forming the sheaths of the foliage leaves (PI. IV $, b, c, d)$ at base. (5) Involucral bracts of the mile flower $(\mathrm{Pl}, \mathrm{V}, f)$. (6) Involucral scales of the fcmale inflorescence (amcnt) (Pl. V, c). (7) The bracts which support the carpellary scale bearing the sced $(\mathrm{Pl} . \mathrm{V}, h){ }^{1}$

The primary leaves, which succeed the cotyledons on the primary axis, are in form and structure true lenves. They are softer than the final foliage leaves, have a broal base, are rounded on the dorsal side and not channeled, the whitish transparent margins being finely but distinctly denticnlate. It is rare that secondary leaves proceed from the axils of these chlorophyll-bearing primary leaves. With the more frequent appearance of the ordinary leaves, these primary leavcs wither and henceforth appear as triangular scale:like coriaceous persistent bracts, with broad, hyaline, long-fringed edges, in the axils of which the undeveloped branchlets are produced bearing the secondary or foliage leaves.

The ellorophyll-bearing primary leaves exhibit a simple structure. The fibro-vascular bundle is single, embedded in a wider ring of large cells free from chlorophyll, and the resinous ducts fewer in number, ole, or rarely more than two, being irregularly situated in the cllorophyll-bearing parenchymatous tissues, and mostly external, i. e., close to the thick epidermis. Bnt few of these leaves arc formed after the appearance of the foliage leaves, and a few of them persist throughont the first season." The cataphyllary leaves forming the sheath of the foliage leaves are in this species composerl of eight successive pairs of bud scales; those of the first pair are blunt, flat, dceply concave and coriaceous, with sharp edges; the others are more membranaceous and with fringed edges, the closely interwoven edges cutwining the base of the fascicle. In the secondary leaves the very unmerons stomata form, on both sides, regnlar longitudinal rows. Parallel with these, at regnlar distances between them and embedded in the parenchymatous tissue, are found bundles of unmerous, elongated, thick-walled cells, the so-called liypodermal or strengthening cells. The resin ducts, not over five in number, described by Engelmann as internal, have becu found in the sprecimen cxamined rather parenchymatous, invariably so on the dorsal side.

Threc of the secondary or true foliage leaves are united into one bundle, inclosed at the base by a persistent sheath from one-half inch to an inch in lengtl, formed by the bud scales or cataphyllary leaves. On the older trecs the leaves are rarely over 8 inches in length, but during the periods of most active growth they are found 12 to 18 inches long. They are finely serrulate, rounded on the back, channeled, and obtusely triangular in cross section.

George Fingelmann: Revision of the Genus Pinus. Transactions of the St. Lonis Academy of Science, 1882.

${ }^{2}$ Engelmann: Revision of Genms Pinus. Trans. St. Louis Acadcmy of Science, 1882, p. 5. $709-N_{0}=13-4$ 


\section{EXPLANATION OF PLATE IV.}

Fig. a, braneh showing the terminal spring shoot of the season with eharaetcristic, large silvery white winter bud; the bundles of leaves arise from the axils of the leaf-braets of the last two seasons, the first leaves of the seeond year already shed; $b$, detached bundlo of mature leaves with sheath; $c, d$, seales of the shcath, magnified three and nine times; e, transverse seetion through base of leaf bundle showiug imbricution of sheath scales, magnified 30 diameters; $f$, transverse scction of an immature leaf, magnificl 30 diamcters; $g$, transverse sectiou of a mature leaf, magnified 45 diameters, showing the microscopie structure (as pointed out for $P$. echinata, $f, f$ ); $h$, longitudinal seetion of the dorsal side of a mature lcaf showing two rows of stomata and the serrated edge, magnified 45 diameters. 


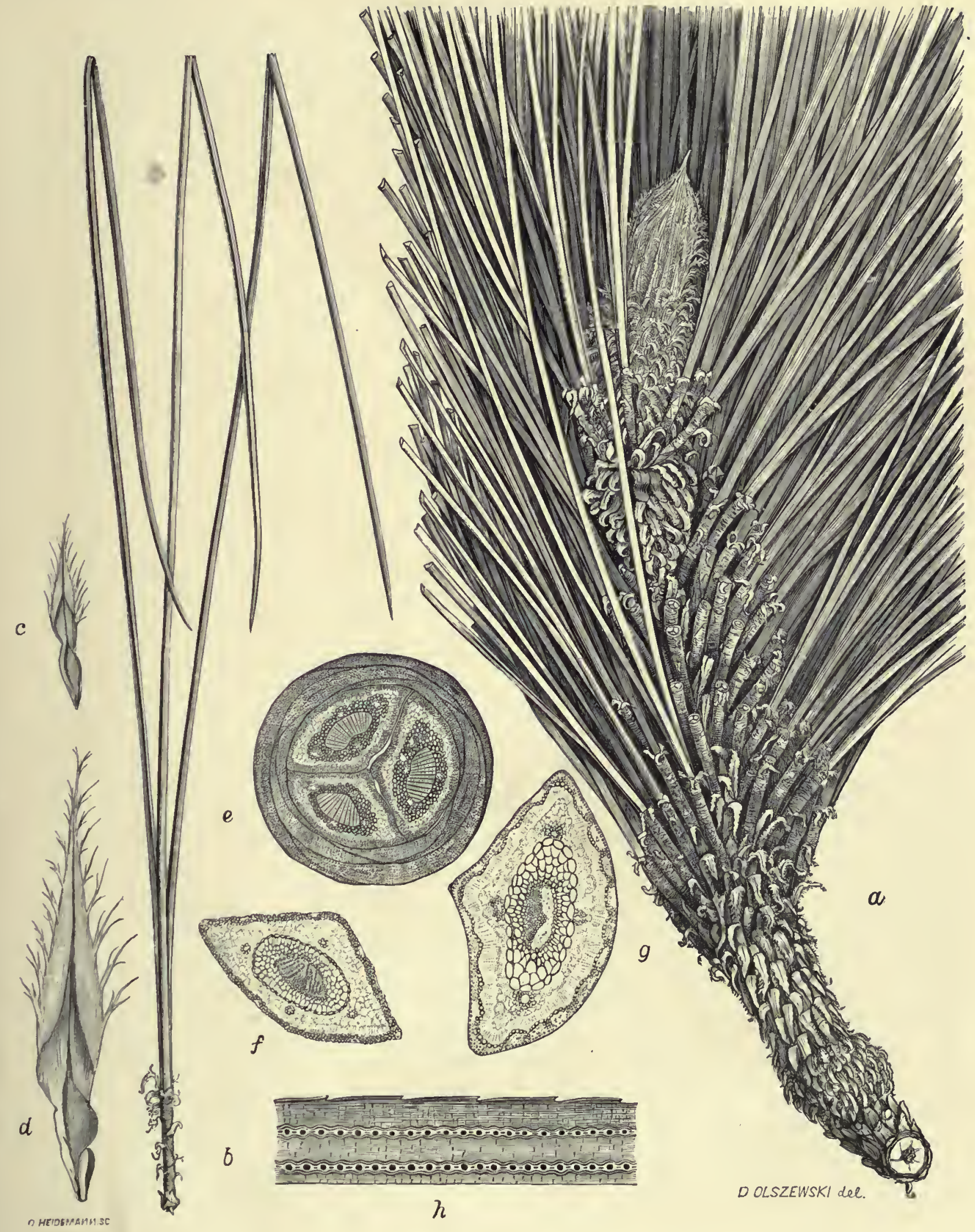



Owing to the shedding of the older leaves at the end of the second year and to the short aunual growth of the axis, the leaves on the older trces are conspieuously erowded into dense tufts or tassels on the tips of the branchlets.

The high development of the organs of transpiration, as shown by the immense number of breathiıg cells, clearly iudicutes that forests of the Longleaf Pine, and in fact of nost evergreens, are not less importint than forests of deciduous trees in influeneing atmospherie eonditions, particnlarly wen $i \mathrm{i}$ is cousidered that in the former, clothed with perpetnal foliage, this function sutter's but little iutermption of its activity.

FLORAL ORGANS.

The male and female flowers are sometimes found on the same branch; they are, however, more frequently situaterl on different branches, the male flowers mostly on the lower (Pl. $\mathrm{V}, b$ ). The male flowers consist of a slender axis, the staminodial column, around which the nnmerous naked anthers are densely crowded, forming a eylindricul catkin-like flower from 2 to 2 inches and over in length, surrounded at the basc by a calyx-like involucre consisting of twelve ovate somewhat leathery bracts, of which the lowest pair or exterior oncs are laterally compressed, strongly keeled, aud muclı smaller. The eonneetive of the dark-rose purple anthers spreads ont in a semiorbicular denticulate crest: a number of these male flowers are crowded around the base of this year's shoot, forming a dense whorl. After the discharge of the pollen the withered flower's remain for several months on the tree. The pollen remaining for a loug time suspended in the air is often wafterl to widely distant localitios. In the latitude of Mobile its discharge takes place during or shortly after the second week of March.

'The female tlower's (see Pl. V, a) are united in a subtermiual oval, erect, short-stalked catkin, which is also surrounded lyy an involucre, the braets being more numerous, longer, more acuininate, and membranaceous than those of the male flower.

The carpellary seales bearing ovules are oblong oval, tipped with a strong reflexed point, and are almost hidden by the thin flat seales by which they are subteuded, which, however, they soon surpass in size. During the first year the young cones make but slow progress in their growth. On the opening of the second season they are scarcely over an inch long; dnring the summer they increase rapidly and reach their full size dnring the latter part of the fill. The cones are placed horizontally on the branches below the terminal bud (subterminal), sessile, slender, conical with a slight curve and from 6 to 8 inches long; of a dull tan eolor; the thick scales are light to dark eliestunt brown on the inside, 2 inches or slightly over in length, and bear on their exposed end, or apoplysis, a small but proninent tubercle armed with a slort reeurved prickle (see PI. VI). Plate VI exhbits truly and fully the op'n cone and especially the fine markings on the apophysis of the scale. The concs are shed in the latter part of the winter of the seeond year, rarely remaining to the following spring. On breaking from the branehes they leave the lowest rows of the seales behind.

SEEDS.

The seeds are strongly convex, oblong, oval, less than a lialf ineh long, and surrounded by the long oblinue wing (sce PI. VI). The shell is whitish, at the front faee marked by three promi. nent ridges, flat, smooth, und dark'y spotted on the posterior side. It ineloses an oily kernel, corered by a white seed coat; rich in nutritious matter and palatable, the sceds furnish in fruitfin years an abmulance of mast. They are shed betore the fall of the cone during dry weather, most almudintly during the latter part of the fall (end of October or November the lost time tor their collection, and in a lesser dongee duriug the winter. They germinate easily after reaching matnrity, and it often lappens, in wet, sultry weather, that they begin to spront before leaving the cone, in which event the whole crop is destroyed. This, together with the killing of the flower's by late trosts, seems to be one of the milu canses of failure of the seed crop so frequently observed. From the behis vior of the seed just mentimed and firom its oleaginous chatracter it is to be inferred thit the period of time during which the seeds retain the power of germination under ordinary circumstances is but a short one, but as a matter of tact seeds a little over a year old have been kuown to germinate. 


\section{EXPLANATION OF PLATES V AND VI.}

Plate V. Fig. a, hranch with two female aments (soeond week of slareh), at the end of terminal yonng shoot of the season densely covered with fimbriate silvery bract snhtending the leaf huds which aro still hidden in their axils; helow are two inmature cones of one season's growth and mature elosed eono of two seasons' growth (October); $b$, brancli with tho male infloreseenee, the leaves eut away to show the dense cluster of naie flowers whieh elusely surround the apex of the young shoot; $c$, fenale ament with basal seales forming the ealyx-like involnere; $d, d, d$, carpellary or seed-hearing scales of femalo flowers more advaneed, lateral, ventral, and dorsal views-magnified 5 dinmeters; e, detached malo flower with basal involucrul seales, before opening (dehiscence); $f$, malo flower, after disebargo of the pollen; g, three detachod anthers, lower sides showing longitudinal slits of tho pollen sacs just opening; lateral view of an effite anther; another seen from npper sido showing the transverse semilunar erest-all magnified 5 diameters; $h$, detached female flower seen from abovo; the cuspidate carpellary, or seed scale, hears two strongly bifid naked ovules at its hase; $i$, female flower viewed from holow, dorsal side; tho hract almost covers the earpellary seale, leaving only the tip of tho latter and the cnsps of the ovnles visible; magnified 5 diameters.

PLATE VI. Fig. $a$, mature open eone, after shedding seed; $b$, cone scale soen from lower or dorsal sido showing the apoplysis with low nmbo and small, weak prickle; $c$, cone scale seen from npper or ventral side with seed in place; $d$, seed, upper side; $e$, seed detaehed from $c$, lower side; $f$, seed detached from wing, npper side, and $g$ the eame seen from lower side. 
Plate V.

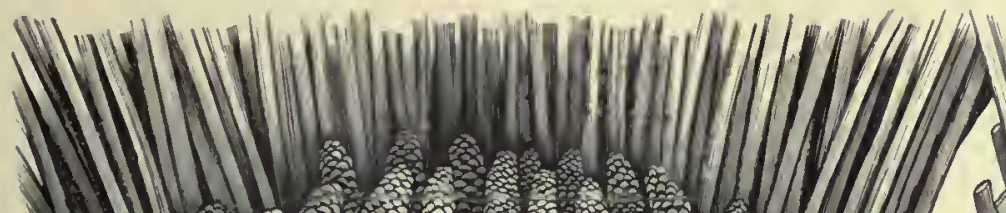
$N$

m.
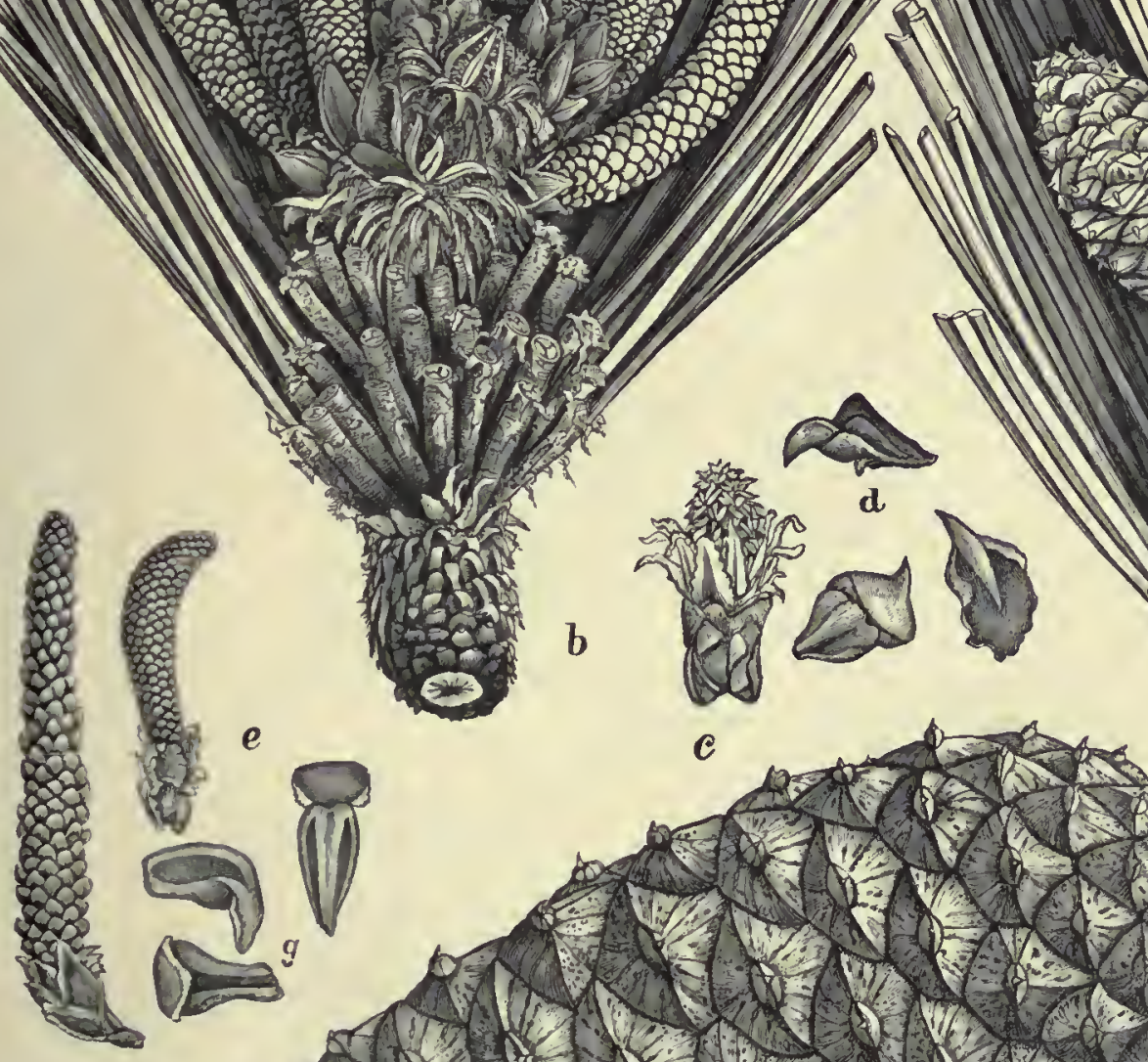

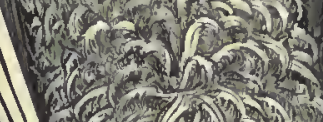

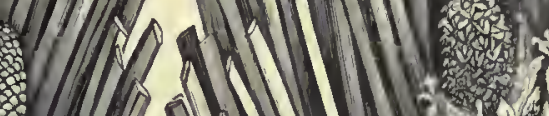

on 0

+ $)^{2}$ NI

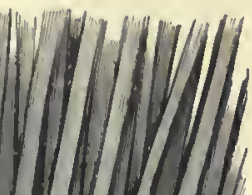




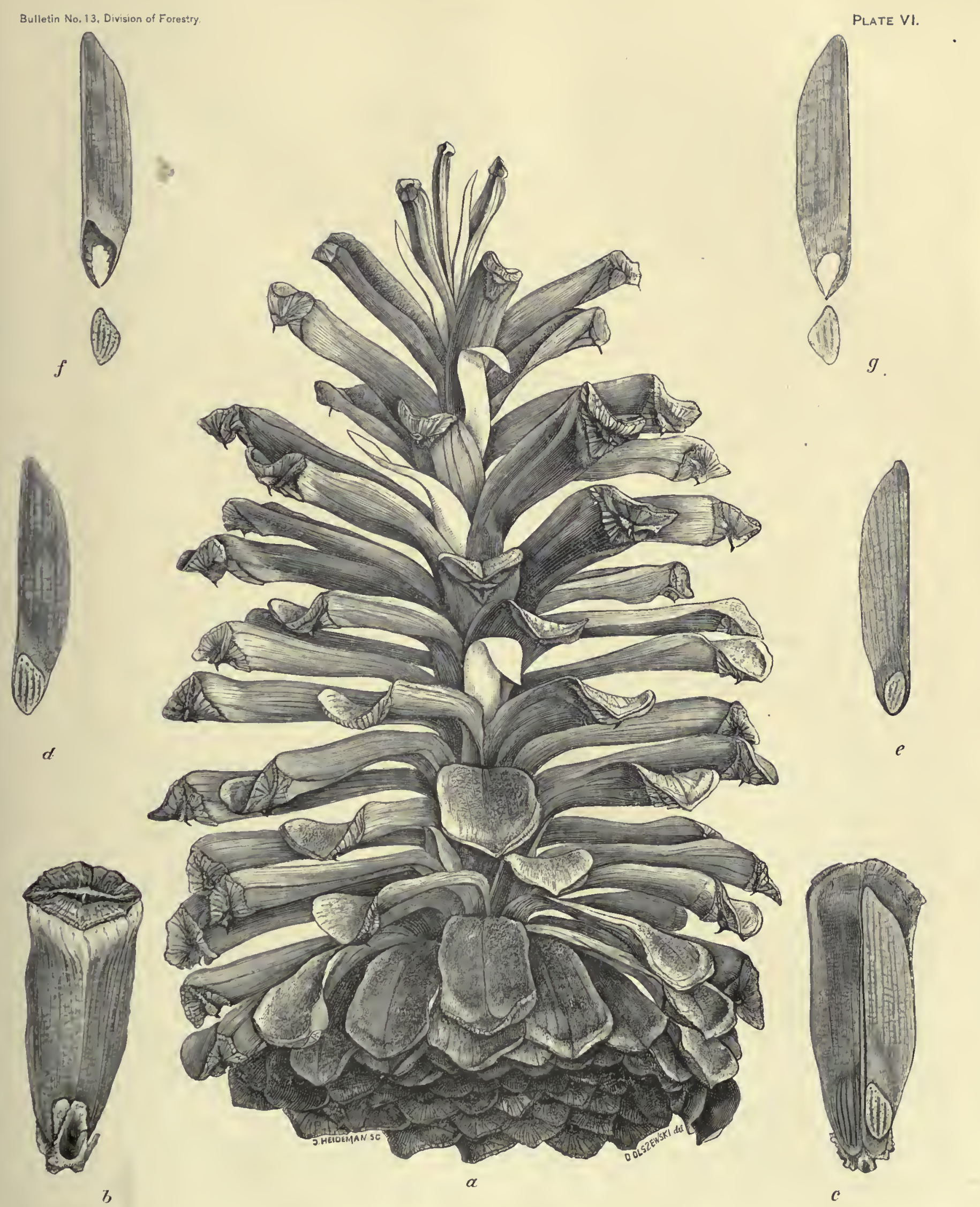

Pinus palustris: Cone and Seed.

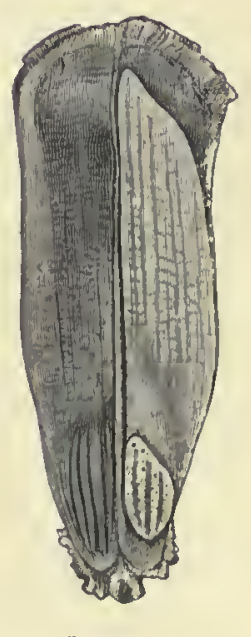

c 

THF WOOD. 1

The wood of the Longleaf Pine is heavier and stronger than that of any other pine offered in the market. The average weight of the kiln-dry wood is about 38 pounds, that of the lumber where the onter lighter portiou of the $\log$ is largely cut away about 40 pounds, per eubic foot. The kiln-dry woos of the butt weighs about 45 pounds per eubic foot; that of a $\log 50$ to 60 feet from the ground only abont 33 ponuds, a deerease of weight (and with it of strength) of about 25 per eent. Similarly the wood of inner portions of a $\log$ are 15 to 20 per cent heavier than those of the outer portions; or, in other words, the wood laid on when the tree is young is heavier than that laid on when it is old, quite contrary to the common belief which seens to associate the light sapwood color of the young sapling with inferior material. The wood shrinks about 10 per eent of its volume in drying, about 6 to 7 per cent along the rings (tangentially) and 3 to 4 per eent along the radius; seasons easily and without great injury. As in other pines, the greatest amount of water is eontained in the sapwood, varying from 30 to 50 per cent of the weight of the fresh wood, while the heartwood contains but about 20 per cent.

In its stiffness and strength the wood is remarkable. The average of a great number of tests indicates for the dry wood of Longleaf Pine an elastieity of $1,540,000$ pounds per sqnare ineh; strength in eross breaking, 10,900 pounds per square ineh; strength in eompression, 6,850 ponuds per square ineh; strength in tension, 15,200 pounds per square ineh; strength in shearing, 706 pounds per square inel.

In its structure the wood of the Longleaf Pine resembles that of the other Sonthern pines. Sapwood and heartwood are well defined; on the fresh eross section the former is light yellowish white, the latter a yellowish brown; drops of limpid resin ooze from every resin duet in the sapwood, the surface of the heartwood remains dry (exeeptions only in "lightwood"). The sapwood eontains mucli more water, but is far less resinons than the heartwood. This latter eontains 5 to 30 per cent of resin ( 1 part turpentine to 15 to 20 parts resin), while in the former the resin rarely exeeeds 2 per cent. If not kiln-dried, fresh sapwood rapidly "blnes" on exposnure; heartwood does not, and in general exeels the sapwood in durability.: On drying, the sapwood shrinks more than the heartwood of the same weight. Contrary to common belief, the wood substanee, or cell wall, is not increased in the ehange from sapwood to lieartwood, the walls do not grow thieker, the cavities of the cells do not fill mp with foreign matter, nor does the strength of the wood seem to be inereased by the change. In general the width of the sapwood is greatest in young and thrifty trees, grows smaller in old and stnnted trees, is greatest in the lower parts of the stem and smaller in the top and branehes. In old $\operatorname{logs}$ the sapwood is made np of from 70 to 100 rings, showing that the wood of any one ring remains in older trees seventy to one hundred years in the sapwood eondition before it ehanges to heartwood. In young trees this period is mueh shorter, twenty.five to forty years commonly suffieing for thrifty trees at the age of sixty to seventy years, but in stunted individuals it is materially prolonged. The share of the sapwood in the total volume of the sten is always considerable; even in typical old trees of this speeies it forms 40 per eent and more, while thrifty stems under one hundred years are praetically all sapwood.

The annual, or yearly, rings are elearly defined; they are widest near the pitl and grow rather uniformly uarrower toward the bark. In the inner part a width of one-twelfth of an inel is quite eomınon; the rings near the bark of old logs nsually measure less than one twenty.fifth of an ineh, often scarcely one-fiftieth of an ineh. For old trees the average width for the entire stem may be set at about one-twentietli to one-twenty-fifth of an inch. Eaeh ring consists of two well-marked parts, an inner, softer, whiter part, the springwood, and an outer, harder, and darker portion, the summerwood, so ealled because formed during the latter part of the growing season.

The amount of the summerwood in eael ring differs in different parts of the tree. It forms about 45 per eent of the volume of all the wood of the stump, and only about 24 per eent of the wood 60 feet from the butt. It is greater in the heavy inner part of an old log than in the lighter onter portions, and being of a darker eolor furnishes a eonvenient means of distinguishing lieavy wood. In its finer anatomy (histology) the wood resembles that of the other pines of the teda group. (For the details of stincture see the comparative study by Mr. Roth appended to these monographs.)

'This statement is furnished by Mr. Filibert Roth, in ehirge of timber investigations in the Division of Forestry. 


\section{EXPLANATION OF PLATE VII.}

[Figures natural size, oxcept where otherwise noted.]

Fig. $a$, germinating seed; $b$, young seedling (early spring) with the 8 cotyledons just unfolded; $c$, seedling a few weeks older, showing central cluster of primary leaves just unfolding; $d$, seedling at the end of the first or beginning of the second season, showing bundles of trus foliage (secondary) leaves succeeding the primary leaves which have disappeared; e, young tree, 3 to 4 years old, with characteristic large root system; one-third natural size. 


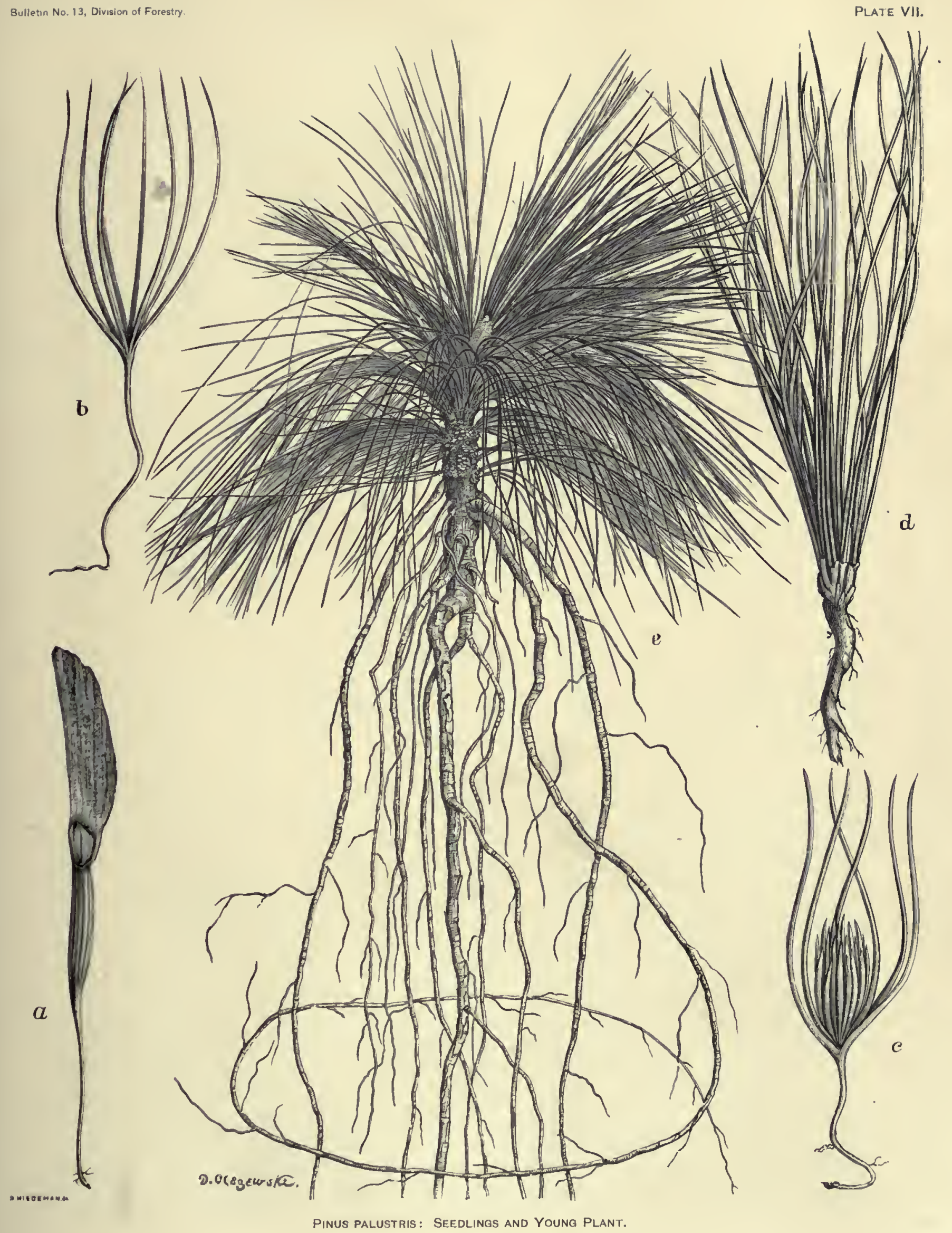



GROWTH AND DEVELOPMENT.

In a fruitful year, before the elose of the season, the seeds are readily shed, a dry and sunny. state of the atmosphere favoring the fall of the seed; the seedlings are found to eome up abun. dantly in every opening of the forest where the rays of the sun strike the dry ground. The lower (hypoeotyledonary) part of the axis of the plantlet is close to the ground, witl eight to ten ereet eotyledons from 1 to $1 \frac{1}{2}$ inches in length, their tips inelosed in the shell of the seed, with the long wing persistent and borne banner-like at the top of the plantlet (Pl. VII, a). The elongation of the aseending axis proceeds slowly, growth in length being retarded until a certain thiekness lias been attained, resembling in this respeet the growth of the stem of endogenous trees.

Upon examination of a seedling in the latter part of April the eotyledons had disappeared and the eauliele was found to be from one-eighth to one-fourth of an ineh long, its length not exceeding its diameter, hidden by a dense tuft of the needle-shaped primary leaves, whieh elosely invest the terminal bud. At this stage a few faseieles of secondary leaves are already showing themselves, still inelosed in their sheaths.

During the first three or fonr years its energy of growth is mainly expended apon the development of its powerful root system (see PI. VII, e). Before the first spring season has passed, the stont spindle-shaped taproot of the seedling is found to be over 3 inehes in length and provided with several fine lateral rootlets, sometimes nearly as long as the main root.

With the opening of June the primary leaves eovering the axis are nearly all withered, only a few remaining to the end of the season. With the development of the suppressed seeondary axes from which the foliage leaves proeeed, the primary leaves are redueed to ehaffy fimbriate bracts. Only few of these primary leaves retain the needle shaped form and green eolor, namely, those from whieh no leaf-bearing branehlets were developed. During the first season many of the fascicles of the foliage leaves eontain only two leaves, and sheaths inelosing only one leaf are fiequently observed.

By the end of the first year the stem of the plantlet is rarely over three-fourths of an inch in . length, the main root having attained a length of from 8 to 10 inehes.

Having reaehed the end of the seeond year the taproot is found from 2 to 3 feet in length, the stem scarcely 11 inches long, with an inerease of diameter hardly perceptible. The eonical termination of the spring shoot is now densely covered with the delicately fringed braets inclosing the buds of the foliage leives, whieh impart to it the appearance of a silvery white tuft, by which this speeies is recogrnizerl at first sight.

During the following two years the growth proceeds but slowly, the length by the end of the fourth year averaging not more than 5 inches with a thiekness of three-fourths to seven-eightlis of an insh. During the same time the taproot is found to gain constantly both in thiekness and length (see P'l. VII, e). A few single branches now make their apjearance on the main axis. The increase of growth from one season to another up to the seventh or eighth year is difficnlt to follow, since the difrerenee in the appearance of the spring and summer wood eells in the spongy wool of young trees is luardly perceptible, and the rings of annual growtl, even as seen in eross sections preparen for inicroseopieal examination, are mostly too indistinct to afford a safe criterion of their age. As fal as eould be observed the growth proceeds equally slowly during the fifth and sixth years, the plant at the end of that period being from 5 to 7 or $7 \frac{1}{2}$ inelies in length.

Stage of rupid.gronoth.-With its seventh year the tree may be said to enter on its most vigorons growth. Heneeforth the stem (primary axis) inereases rapidly in length, and the (levelopment of branehes (lateral axes) proceeds at an equal rate in regular whorls, to whieh the symmetry of the tree in that stage of its development is due. Dnring the seventh year, generally, the tree doubles its length, and during a number of successive years the rate of growth in that direction varies between 10 and 20 inches annually, as is clearly shown by the length of the internodes separating the whorls. As the branehes increase in length they produce, in the same order mostly, two opposite seeondary branches. With the rapid expansion of the leaf surfaee, the formation of wood keeps pace. The rate of growth in diameter, as well as in height, during this period, is of conrse variable according to differences in the pliysical condition of the soil as well as in the available amount of plant food and noisture it contains, and wo less upon differences in temperature and of exposure to light and air. These variations me elearly shown 
in the annexed tables, exhibiting the rate of growth of the tree during its most active stage. With the increasing aceretion of wood the anmal rings beeome sharply defined, leaving no doubt as to the age of the tree.

To make sure as to the relation between the annual rings and the age of the tree, the age of second growth was aseertained by elose inquiries directed to settlers who knew tho time that had elapsed sinee this seeond growtl made its appearanee in the abandoned fields or in the forest. In every instanee it was fommd that the number of rings aeeorder closely with the information elieited.

To ascertain the difference in rate of growth and guality of wood between trees grown upon gromncl once turned hy the plow and those sprung up in the original forest on the same soil, several trees of nearly the same size were felled in what clearly appeared to be the remnant of virgin forest, and in a grove grown up in a field abandoned years ago.' It was made evident that trees in the original forest required ahost double the length of time to attain the same dimension.

A field eovered with saplings quite nniform in growth and know to have heen thrown ont of euitivation dnring the years 1863 and 1864 afforded a gool opportunity for these investigations. $\Lambda$ number of trees, varying in diameter between 10.2 and 11 inehes, and in height between 45 and 50 feet, showed from 30 to 35 rings of growth. The length of the spring shonts on the main stem of these trees was fonnd (June 8 ) to be from 21 to 24 inches.

In another fine grove, eovering a field whieh was kiown to have been enitivated for the last time during the years 1835 and 1836 , a number of trees were cut down for measurement. The number of rings was found not to exceel 48. These trees also showed great miformity in size, measuring near the base $11 \frac{1}{2}$ to 12 inclies in diameter and from 68 to 72 feet in lociglit. The wood was sappy throughout and useless, except for fuel and for making chareoal. For this purpose the land is rented at $\$ 4$ to $\$ 5$ per nere. In this grove, ranking as best pine-woods land, the soil of which was nearly level, well drained, and with a light, loany subsoil, 110 trees of the above dimensions were counted on 1 acre.

Among the trees taken from the forest for determining the difference between forest growth and fiek trees, one measmring 12 inches in diameter and 60 feet in height showed Si rings of annual growth, with $9 \frac{1}{2}$ inches of heartwood. Two others, 14 and 15 inehes in diameter and 70 and 71 feet high, showed $9(6$ rings each. The shoots of the year (June \&) on the primary and lateral axes of these trees were found to be but little over 1 inch in l'ngth.

In a third grove, upon poor, sandy, undulating ground, a number of trees belon medium size were fonnd eut down to serve for posts and logs. In 25 of these trees the diameter varied between 73 and 8 inehes, with a nearly uniform height of 60 to 62 feet, the first lin b being 18 to 20 feet above the ground. The nunher of rings varied between 45 and 50 . 'The forests in the same vieinity were stripped of their more valuable timber a number of years before. The largest trees of the original forest growth remaining were from 12 to 15 inches in dianeter. Several were bronght down for' measurement and found to be 73 feet in height by 14 inehes in dianeter, with 126 rings and 9 inehes of heartwood; 73 feet in height by 13 inehes in diameter, with 94 rings and 6 inches of heartwood; and 89 feet in height by 14 inehes in diameter, with 107 rings and 8 inelies of heartwood.

When the tree has reaehed its seeond deeade it begins to produee flowers and fruit. Having during the eourse of the following ten to fifteen years reached a length of fiom 40 to 45 feet, with the main stem elear of limbs, the growth of branehes does not proceed with the same regnlarity: eonsequently, they are no longer arranged in recrular whorls, but appear irregularly, and thus the symmetry of the tree is lost.

\footnotetext{
I On the rolling pine uplands near spring llill, Mobile County.
} 
TABLE I.-Measurements of young trees of Longleaf Pine.

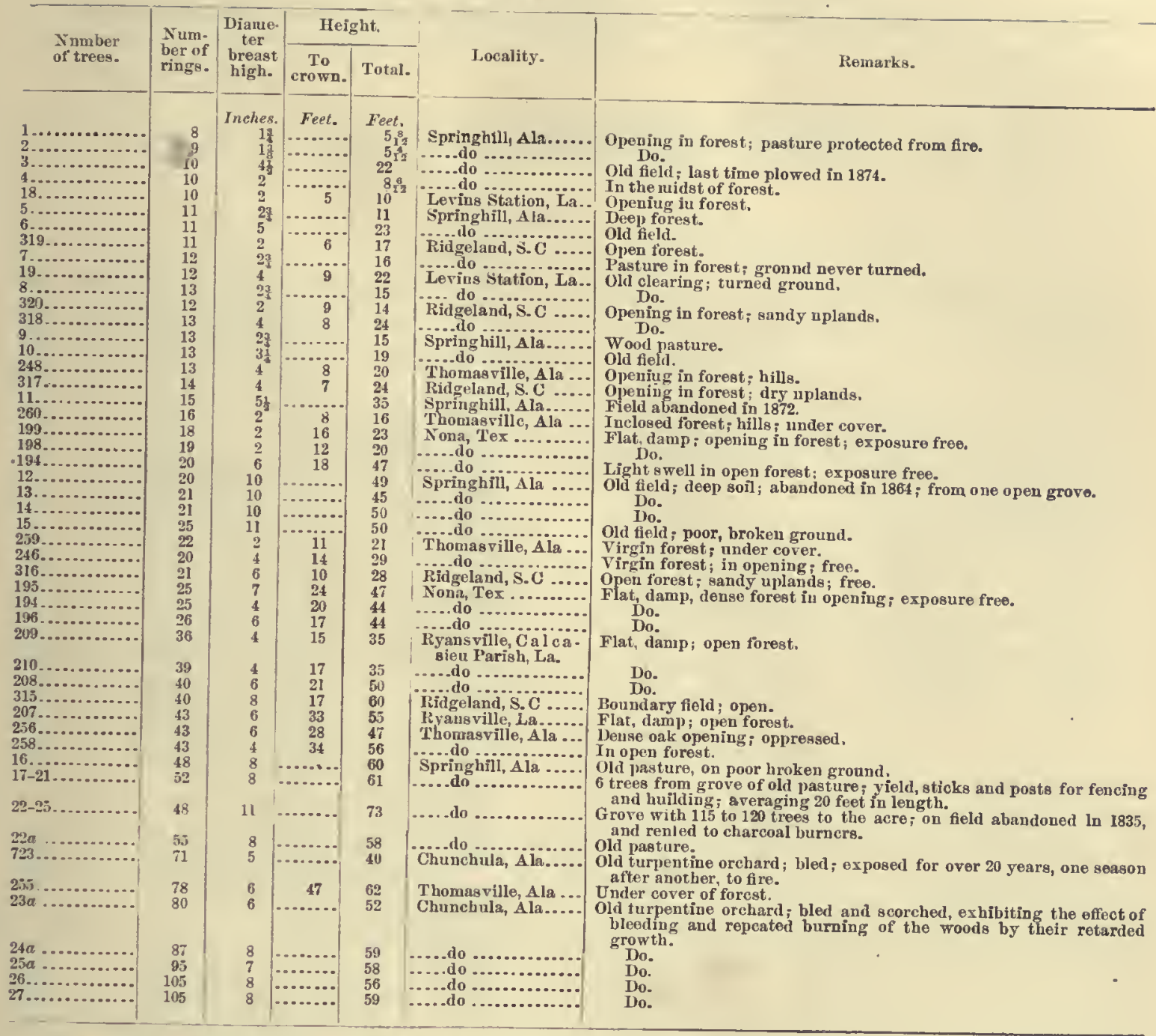

Stage of slow growth.-Rapid as is the inerease iu length of the primary axis or trunk, amounting during the first half eentury, in the average, to 14 or 15 inches aniually, the rate is subse. quently greatly diminished, averaging from the fiftieth to about the one hundred and fifteenth year lout from 4 to 5 inehes, and from this time to the age of two hundred and fifty years only $1 \frac{1}{2}$ inches-that is, at a relative rate of 10,3 , and $1 \mathrm{in}$ the three suceessive periods. The deerease in the aeeretion of wood corresponds with the reduetion in the growth of the branehes and eonsequent reduction of foliage. From what has been said, it is seen that the Longleaf Pine attains fullness of growth, with the best qualities of its timber, at an age of from one hundred and eighty to two lundred years. After liaving passed the seeond eentury the trees are found frequently to be wind shaken and of herwise defective. The deterioration of the weather-beaten crown lessens the vitality of the tree, and the soil, under prevailing conditions, beeomes less and less favorable. In conseruenee, the trees become liable to disease and mostly fall prey to the attacks of parasitie fungi (red heart). Instanees of trees which have reached the maximum age of two linndred and seventy-five or three lundred years are exceptional.

In order to ascertain the age required to firnish merehantable timber of first quality, measurenents were made of a number of $\operatorname{logs}$ in a $\log$ eamp in the rolling pine uplands of the lower division of the eoastal pine belt near Iumberton, Washington County, Ala. From the results obtained it appears that in this seetion of the eastern Gulf rogion, at the lowest figure, one hundred and fifty to one lumdred and seventy-five years are requisite to prodnee logs of the dimensions at present cut at the sawmills. 
'ТАнц: II.-Measurements of Longleaf I'ine-period of slower grouth from one hundred to two hundred years.

\begin{tabular}{|c|c|c|c|c|c|c|c|c|c|c|c|c|c|c|c|c|c|c|}
\hline \multirow{3}{*}{$\begin{array}{l}\frac{8}{2} \\
\frac{5}{5} \\
\frac{5}{8} \\
\frac{5}{3} \\
7\end{array}$} & \multirow{3}{*}{ 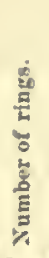 } & \multirow{3}{*}{ 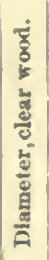 } & \multicolumn{2}{|c|}{ Helght. } & \multirow{3}{*}{ 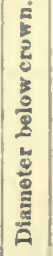 } & \multirow{3}{*}{ 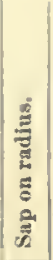 } & \multirow{2}{*}{\multicolumn{5}{|c|}{$\begin{array}{l}\text { Increase in diam- } \\
\text { eter for each } \\
\text { sucressive balf } \\
\text { century, In } \\
\text { lnches. }\end{array}$}} & \multirow{2}{*}{\multicolumn{5}{|c|}{$\begin{array}{l}\text { Number of years re. } \\
\text { quircd for every lnch } \\
\text { of wood for each anc- } \\
\text { cesslve half ccntary. }\end{array}$}} & \multirow{3}{*}{ Locality. } & \multirow{3}{*}{ Retnarks. } \\
\hline & & & \multirow{2}{*}{ 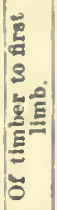 } & \multirow{2}{*}{$\stackrel{5}{5}$} & & & & & & & & & & & & & & \\
\hline & & & & & & & 1 & 2 & 3 & 4 & 5 & 1 & 2 & 3 & 4 & 5 & & \\
\hline 190 & 105 & In. & $\begin{array}{l}F t . \\
62\end{array}$ & $F t$ & In. & In. & & & & & & & & & & & Nona, Tex... & Flat; soll, deep sandy loam, damp; vlr- \\
\hline 20 & 110 & 17 & 36 & 82 & & & & & & & & & & & & & Wallace, Ala.... & $\begin{array}{l}\text { Gently rolling, pline upland, close; rlr- } \\
\text { gin forest; slightly ander cover and } \\
\text { oppressed. }\end{array}$ \\
\hline 70 & 105 & 14 & 38 & 85 & & & & & & & & 51 & 68 & & & & $\begin{array}{l}\text { Wilaon, Ala.. } \\
\text { Chnnchnla, A }\end{array}$ & $\begin{array}{l}\text { Bored timber; abandoned for fire years; } \\
\text { dry pine, rollng plne forest ; ex pusure } \\
\text { free. } \\
\text { Open forest ; cxposure frec. }\end{array}$ \\
\hline 13 & 110 & 14 & 45 & 78 & & & 41 & & & & $\cdots$ & 11.1 & 9.5 & & & & .....do... & $\begin{array}{l}\text { Do. } \\
\text { Doresti caposure irec. }\end{array}$ \\
\hline 180 & 112 & 15 & 50 & 97 & 11 & & & & & & $\cdots$ & ...... & & & & $\cdots$ & Loving Station, La. & Do. \\
\hline 191 & 113 & 20 & 53 & 110 & 15 & & & & & & $\cdots$ & ….. & & & & $\cdots$ & Nona, Tex . & Flat woods; closed forest; damp, etc. \\
\hline $\begin{array}{r}313 \\
9\end{array}$ & 114 & $\begin{array}{l}12 \\
12\end{array}$ & $\begin{array}{l}30 \\
38\end{array}$ & $\begin{array}{l}83 \\
83\end{array}$ & $\cdots$ & $\dddot{3}$ & 51. & 4 & & & $\cdots$ & $9 . i$ & i1.i & & & & Ridigeland, s.C.... & Clearing in forest ; soil dry, sandy. \\
\hline 200 & 115 & 17 & 70 & 96 & $\ldots$ & & & & & & $\cdots$ & & & & & & Nolla Tex........ & Flat woods: roildamp; crown oppressed. \\
\hline & 116 & 121 & 46 & 81 & $\cdots$ & & 5) & 5 & & & $\cdots$ & 9.7 & 10 & & & $\ldots$ & Clinnehula, Ala. & Rolling yine woods; dry, sandy. \\
\hline 67 & 116 & 13 & 48 & 87 & & & & & & & 1 & & & & & & Wilson, Ala.. & $\begin{array}{l}\text { Bored; dry uplands; open forest; par- } \\
\text { tiaily free. }\end{array}$ \\
\hline 253 & 118 & 15 & 45 & 84 & 11 & & & & & & $\ldots$ & & & & & & Eastman, Ga...... & $\begin{array}{l}\text { Geutly rolling uplands, dry; open for- } \\
\text { est; exposure free. }\end{array}$ \\
\hline 21 & 123 & 17 & 40 & 84 & $\ldots$ & 21 & 69 & $6 \%$ & & & $\ldots$ & 7.7 & 7.8 & & & ... & Chunchula, Ala. & Do. \\
\hline 23 & 125 & 18 & 61 & 102 & $\cdots$ & & 9 & & & & $\cdots$ & 5.5 & 9. & & & & Sprlnghill, Ala.. & $\begin{array}{l}\text { Exposed slope; open forost; soil, loany } \\
\text { sand; cxpusure free. }\end{array}$ \\
\hline 251 & 133 & 18 & 44 & 93 & 13 & & & & & & $\cdots$ & & & & & & Eastinan, Ga... & Open forest; dry, sandy : exposure frof. \\
\hline 237 & 135 & 17 & 54 & 95 & 10 & & & & & & $\ldots$ & & & & & & Renfroe, Ala & $\begin{array}{l}\text { Kocky hillsido ; dry suhaoil, loam ; expo- } \\
\text { muro free. }\end{array}$ \\
\hline 252 & 145 & 10 & 49 & 96 & 14 & & & & & & . & & & & & & .....do. & $\begin{array}{l}\text { Rocky hillside; dry sabsoil, loam; par- } \\
\text { tially free. }\end{array}$ \\
\hline 309 & 145 & 22 & 62 & 102 & & 5 & & & & & & & & & & & Ridgeland, S.C & $\begin{array}{l}\text { Gentiy undulating open forest; loamy } \\
\text { sand; expoauro frec. }\end{array}$ \\
\hline 312 & 140 & 20 & 63 & 99 & & $2 \frac{1}{2}$ & & & & & & & & & & & $\ldots$ & $\begin{array}{l}\text { Open pine forest; saudy loam, dry; } \\
\text { exposure free. }\end{array}$ \\
\hline $\begin{array}{r}177 \\
24\end{array}$ & $\begin{array}{l}155 \\
155\end{array}$ & $\begin{array}{l}23 \\
18\end{array}$ & 63 & $\begin{array}{r}122 \\
98\end{array}$ & 16 & & 6 & 5 & & & .. & 8.3 & 8.7 & & & & $\begin{array}{l}\text { Leving Station, La. } \\
\text { Springhill, Ala... }\end{array}$ & Do. \\
\hline 19 & 160 & 24 & 43 & 111 & & & & & & & & & & & & & & $\begin{array}{l}\text { posure freo. } \\
\text { Close forest; deep sandy loam; expo- }\end{array}$ \\
\hline 238 & 165 & 21 & 35 & 97 & 15 & & & & & & & & & & & & Renfroe, A & $\begin{array}{l}\text { snre free. } \\
\text { Rocky lillside; forest open; dry; expo. } \\
\text { gnre free. }\end{array}$ \\
\hline 205 & 167 & 16 & 84 & 125 & 8 & 2 & & & & & & & & & & ... & $\begin{array}{c}\text { Ryansville, Calca- } \\
\text { sieu Parish, La. }\end{array}$ & $\begin{array}{l}\text { Flat woods, damp; close forest; expo- } \\
\text { sure tree. }\end{array}$ \\
\hline 230 & 170 & 21 & 50 & 108 & 14 & & & & & & & & & & & & & Do. \\
\hline 178 & 170 & 21 & 62 & 117 & 13 & & & & & & .. & & & & . & $\cdots$ & $\begin{array}{l}\text { Lerina Station. } \\
\text { liapides Parish, } \\
\text { La. }\end{array}$ & $\begin{array}{l}\text { Rolling open forest; sandy loan; ; expo- } \\
\text { sure froe. }\end{array}$ \\
\hline 204 & 180 & 19 & 56 & 102 & 11 & & & & & & & & & & & & Wallace, Ala.... & $\begin{array}{l}\text { Rolling pine woods; leep aandy loam; } \\
\text { partially free. }\end{array}$ \\
\hline 4 & 182 & 10 & 70 & 113 & & & & & & & & & & & & & $\ldots$... llo & $\begin{array}{l}\text { lolling pine woods; deep sandy loam; } \\
\text { slightly oppressed. }\end{array}$ \\
\hline 5 & 183 & 16 & 53 & 111 & & & & & & & & & & & & & t & Rolling jine woods; deen sandy loan; \\
\hline 6 & 189 & 19 & 57 & 111 & & & & & & & & & & & & & ......do & $\begin{array}{l}\text { Rolling pine woods; deep sandy loam; } \\
\text { partinlly under cover. }\end{array}$ \\
\hline 203 & 190 & 21 & 58 & 117 & 11 & & & & & & & & & & & . & $\begin{array}{l}\text { Ryansvllle, Calca- } \\
\text { sieu Parish, La. }\end{array}$ & Flat woods; loamy, damp; free. \\
\hline
\end{tabular}


TABLE III.-Measurements of Longleaf Pine-period of slowest growth from noo hundred to two hundred and sixty-8ix years.

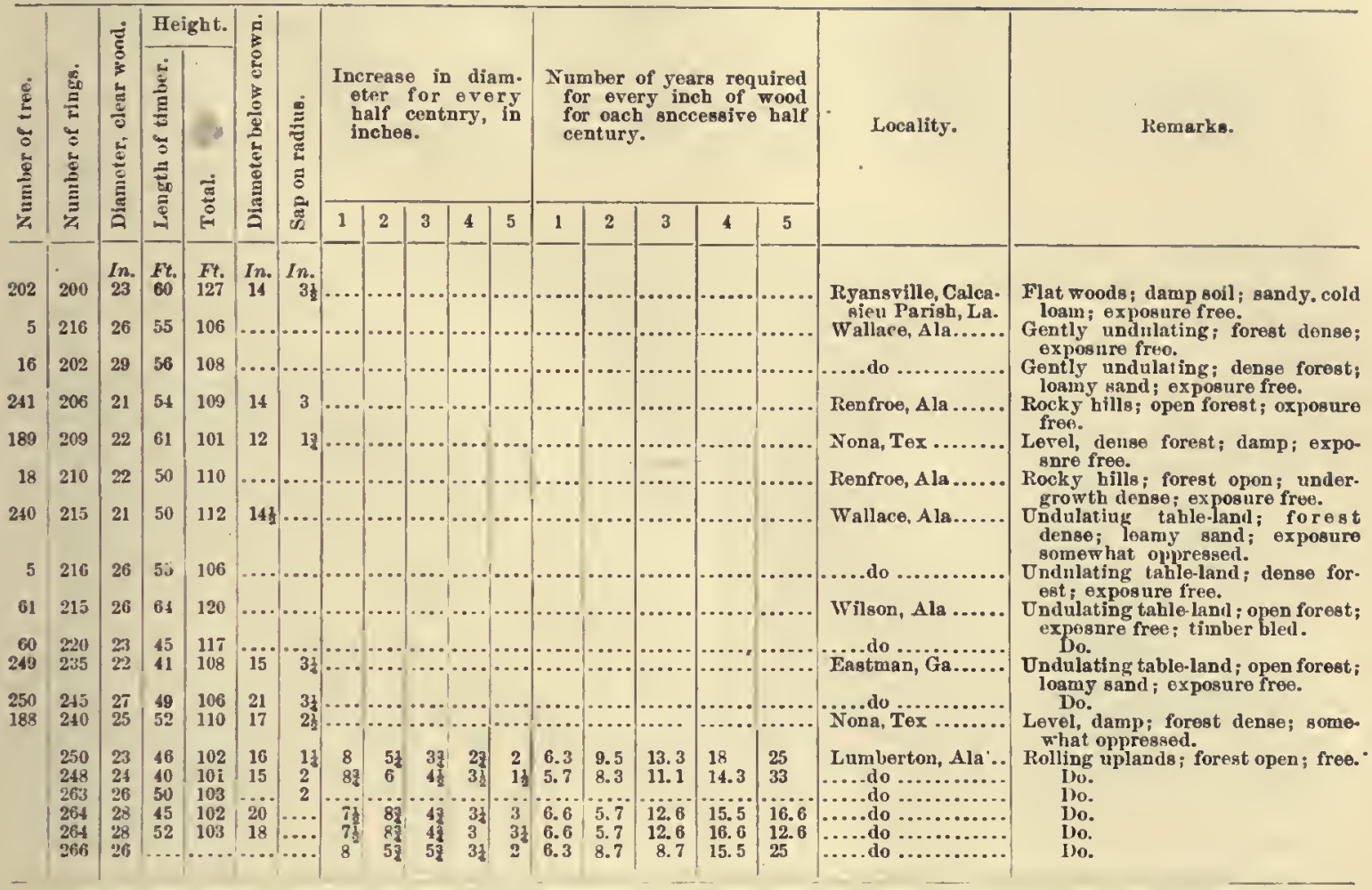

The following table and diagram (fig. 8) present the average results of a detailed study of over sixty trecs collected in different localities. Since only the part of the sten from stump upward is representerl, the seedling period of slow growth finds no expression. It will be observed that the growtl in height is a maximuin between the age of ten and thirty years, anounting to 14 fect for each decade; that it is but half of this at sixty and little over one-third at the age of one hundred years. As plainly indieated in the fine, uniform grain of the wood, the growth in diameter is remarkably uniform until the tree reaches the age of about one hundred years. From this on it decreases rapidly and is searcely more than one-fourth as great at one hundred and eighty as it is at one hundred. The rate of growth in volume inereases steadily up to the one hundredth year, reaching a maximum of over 1.2 eubic feet per year, but deereases, though very slowly, from that time forward, being only about one-half eubic foot per year when the tree reaches the age of one hunilred and eighty years.

Rate of growth of Longleaf Pine.

\begin{tabular}{|c|c|c|c|c|c|c|c|c|c|c|c|c|}
\hline \multirow{2}{*}{ Age. } & \multirow{2}{*}{$\begin{array}{l}\text { Diam- } \\
\text { efer } \\
\text { with } \\
\text { hark } \\
\text { (breast } \\
\text { lifgh). }\end{array}$} & \multirow{2}{*}{$\begin{array}{l}\text { Length } \\
\text { of tim- } \\
\text { ber, } \\
\text { with } \\
\text { upper } \\
\text { diame- } \\
\text { ter of } \\
\text { inches. }\end{array}$} & \multirow{2}{*}{$\begin{array}{l}\text { Meight } \\
\text { of tree. }\end{array}$} & \multicolumn{2}{|c|}{ Volume. } & \multicolumn{5}{|c|}{ Periodical accretion. } & \multirow{2}{*}{$\begin{array}{l}\text { Average } \\
\text { annual } \\
\text { accretion. }\end{array}$} & \multirow[b]{2}{*}{$\begin{array}{l}\text { Current } \\
\text { accretion }\end{array}$} \\
\hline & & & & Tree. & Log. & Decade. & $\begin{array}{c}\text { Diame- } \\
\text { ter. }\end{array}$ & Height. & $\begin{array}{l}\text { Area of } \\
\text { crosg sec } \\
\text { tions. }\end{array}$ & Volume. & & \\
\hline & Inches. & Feet. & Feet. & Cre. seet. & Or. feet. & & Inches. & Feet. & Sq. foot. & Cu. feet. & Cu. feet. & Cu. feet. \\
\hline $\begin{array}{l}10 \\
20\end{array}$ & $\begin{array}{l}2.0 \\
3.8\end{array}$ & & & 0.12 & ... & First.. & 1.4 & 9 & 0.01 & 0.12 & & \\
\hline 30 & $\begin{array}{l}3.8 \\
5.5\end{array}$ & & 37 & $\begin{array}{l}1.20 \\
3.35\end{array}$ & $\cdots$ & $\begin{array}{l}\text { Secor } \\
\text { Thir }\end{array}$ & 1. & $\begin{array}{l}14 \\
14\end{array}$ & .04 & $\begin{array}{l}1.08 \\
2.15\end{array}$ & .11 & .11 \\
\hline 40 & 7.0 & i6 & 48 & 7.06 & 5.61 & Fourth ....... & 1.2 & 11 & .08 & & .18 & .37 \\
\hline 50 & 8.1 & 24 & 56 & 10.75 & & Fifth & 1.2 & 8 & .08 & & .21 & .37 \\
\hline 60 & 9.6 & 34 & 62 & 15. 26 & 13. & sixth. & 1.4 & 6 & .12 & 4.51 & .25 & .40 \\
\hline 70 & 11.5 & 44 & 67 & 24. & & Seventh & 1. & 5 & .1 & & .35 & .89 \\
\hline 80 & 13.0 & 52 & 72 & & 32 & Eigl & 1. & 5 & .1 & 9.02 & .41 & .90 \\
\hline 80 & 14. & 36 & 76 & & & & 1. & 4 & .1 & & .48 & 1.04 \\
\hline 100 & & 60 & 80 & & & & 1. & 4 & .1 & & .56 & 1.23 \\
\hline 120 & & 65 & 87 & & & ausd & 1. & 7 & .3 & & .64 & 1.05 \\
\hline 140 & 19. & 72 & 93 & 9 & & $\mathrm{~T}$ & 1. & 6 & .2 & & . & .98 \\
\hline 160 & 20. & 80 & 98 & & & Fifte & $\because 0$ & 5 & .16 & 15.86 & & .79 \\
\hline 180 & 21.3 & 85 & 103 & 122.00 & 121.20 & Seventeenth and eighteenth & .75 & & .12 & 10.76 & & .53 \\
\hline
\end{tabular}




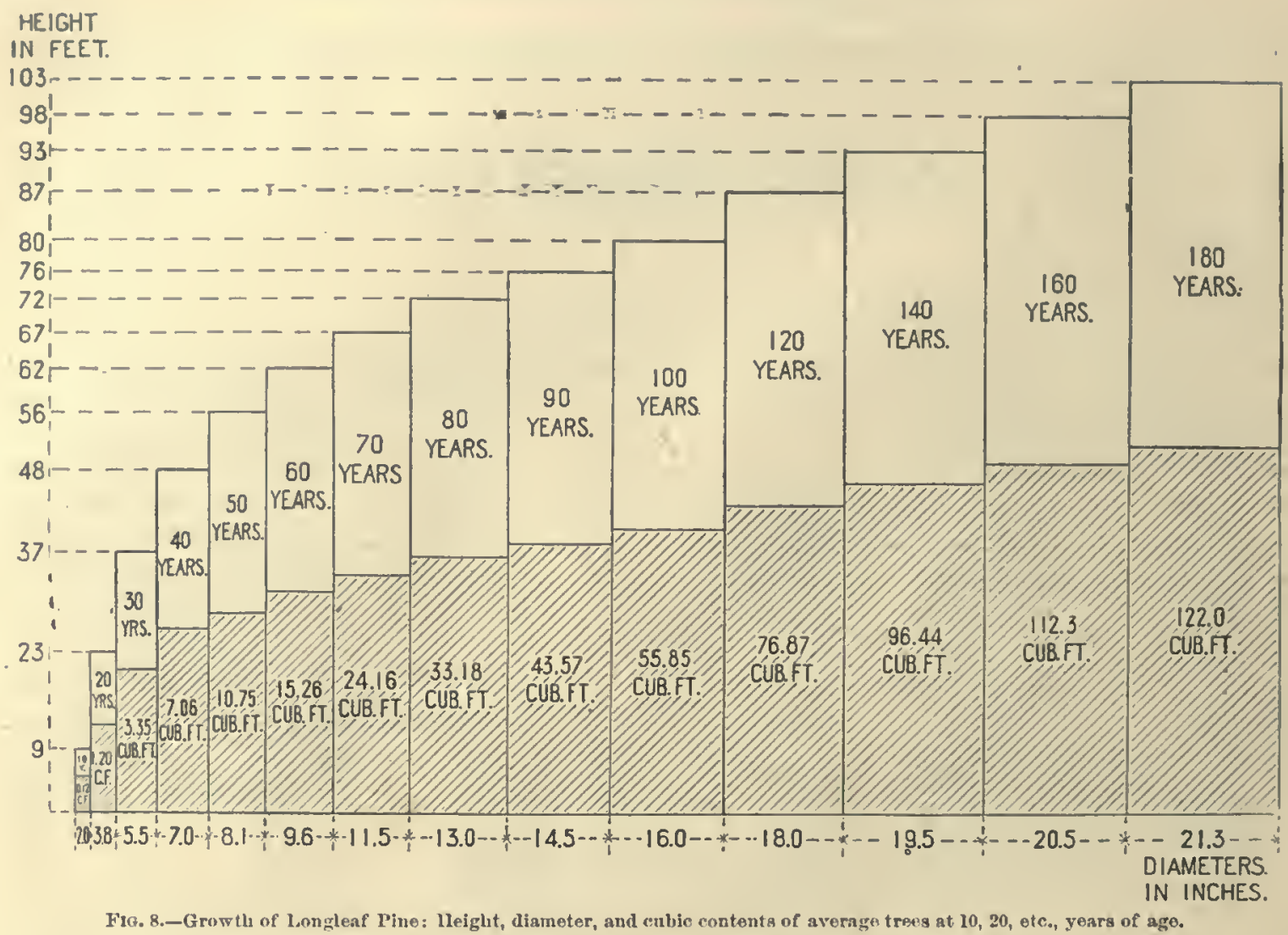

CONDITIONS OF DEVELOPMENT.

Demands upon soil and climate. - In its demands upon the soil this pine is to be connted annong the most frngal as far as mineral constituents, which are considered as plant food, are concerned, if only the mechanical conditions which influence favorable soil moisture are not wanting. It thrives best on a light siliceous soil, loamy sand or pebbles or light sandy loam, with a slightly claycy subsoil sufficiently porous to insure at least a partial underdrainage and to permit unimpederl development of the long taproot. Whenever the tree meets an obstacle to the development of this root it remains more or less stunted.

The luxuriance of the growth and inerease in size of the timber, however, is greatly intluenced by the quantity of clay present, particularly in the deep snisoil, which improves mechanical and moistnre conditions. This is strikingly exhibited in the tinber of the level pine flats west of the Mississippi Liver, althongh the surfaec dranage is ahnost wanting and the underdranage through the loamy strata slow, so that the surface of the soil remains dann or water-soaked for the greater part of the year; the stand of timber of first-class dimcusions exceeds considerably that of the rolling pine uplands on the Atlantie slope and the lower part of the pine belt in the Gastern (Gulf region, which are poorer in clay. Evidently, although the underdrainage is less perfect, the moisture eonditions during the dry season of the year, the time of most ative growth, must be most farorable. The same fact is apparent in the mper part of the coast pinc belt in Alabaua and Mississippi, where upon the same area, with a smaller number of trees, the crop of timber may be considered almost twice as heavy as that found on the pine barrens proper further south. On the soil of fine, closely compacted sand, entirely deficient in drainage as fonnd in the so-called pine meadows along the const of western Filorda, Nabana, and Mississippi, as well as on the silieeous roeky ridges of central and northern Alabama, the trce is so stunted as to be of little or no value for its timber.

"It is neither temperature alone, nor rainfall and moisture conditions of the atmosphere alone, that influence tree growth, but the relation of these two climatic factors, which determines the 
amount of transpiration to be performed by the foliage, and again with most species we must place this transpiration movement into relation with available soil unoisture, in order to determine what the requirements and the most sutable habitat of the species are" (B. E. Fernow). Hence we find that east of the Mississippi River the Longleaf Pine occurs in greatest frequency along the isotherm of $60^{\circ} \mathrm{F}$. ranging to the $34^{\circ}$ north latitude, while west of the Mississippi it follows a line betwcen the isotherms of $63^{\circ}$ and $6 t^{\circ} \mathrm{F}$. and is scarcely found north of the thirty-second parallel of north latitude. Wittin this area of its distribution it is cxposed to wide variation of temperature and moisture conditions.

Under the inflnence of the vapor-laden breezes from the Mexican Gnlf and an cvenly distributed rainfall ranging from 42 to 63 inches during the year, the Longleaf Pinc appears of the same thrift and vigor of growth in the interior of Alabama nnder $34^{\circ}$ to $35^{\circ}$ north latitude, with the thermometer falling as low as $4^{\circ} \mathrm{F} .\left(-16^{\circ} \mathrm{O}\right.$.) and a range of temperature of $93^{\circ}$ (at Tuscaloosa), as it is found in the subtropical belt of the coast with a maximum temperature of $105^{\circ} \mathrm{F} .\left(40^{\circ} \mathrm{C}\right.$.) and a range of temperature of $94^{\circ}$; west of the Mississippi River, beyond longitude $97^{\circ}$ and above latitude $32^{\circ}$, although the temperature reaches rarely a minimum of $15^{\circ}$, the diminished linmidity of the atmosphere and lesser rainfall, particularly during the warmer scason, account for its absence. There can be no doubt that the greater exposure to the violence of the sudden gusts of dry and cold wind known in Texas as "dry northers" cxereises also no small influence in limiting the Longleaf Pine.

ASEOCIATEI, SPICINS.

The Longleaf Pine is eminently a gregarions tree, covering areas of wide extent, to the almost complete exclusion of any other species. In the flat woods of the coastal plain, particnlarly near its northern linit on the Atlantic Slope, it is not infiequently associated with the Loblolly Pinc; farther sonth and along the Gulf Const to the Mississippi River, more or less freqnently with this trec and the Cuban Pine. In the npper part of the maritime pine belt it not rarely occurs togcther with the Shortleaf Pine and the Loblolly Pine intermixed with the deciduous trees of the nplands, viz, the Black Oak, Spanish Oak, Blick-jack, Bitternut, Mockernut Hickories, and Black Gnm.

It will be apparent, from what has been said regarding the demands for light, that the associated species must be cither slower growers or later comers, if the Longleaf Pine is to survive in the mixturc. As has been pointed out elsewhere, with the culling of the Longleaf Pine from the mixed growths it must soon cease to play a part in them, since its renewal nnder the shade of the remaining associates is impossible.

\section{ENEMIES.}

The greatest danger threatening the existence of the forests of Longleaf Pine must be ascribed to the agency of man, since their destruction is cansed chicfly by the reckless manner in which they are depleted without heed to recuperation. The right of ownership has been generally acquired on such low terms that since no value has becn attached to the land without the timlser, despoliation has bcen carried on with no other object than the quickest return of unonentary profits.

EXPLOITATION.

Sucli management could not but entail tremendous waste, a large percentage of the body of the trecs felled being left on the ground to rot or to serve as fuel for the conflagrations which scour these roods almost every year. Infinitely greater than the injuries inflicted upon the forest by the logger and by getting ont cross-ties and hewn square timber, which consist chicfly in the acenmulation of combustible waste, are those caused by the production of naval stores. When the fact is considered that the production of the 40,000 barrels of spirits of turpentine, which on an average during the latter half of this decade annally reached the market of Mobile alone, implies the devastation of abont 70,000 acres of virgin forest, the destruction caused by this industry appears in its full cnormity. Under the management of the turpentine orchards prevailing at present, trees of such small size are tapped that they are unable to resist the force of the winds, and in a few years are inevitably prostrated, while the larger trees, weakened by the severe gashes on alnost cvery sidc, become largely wind shaken, and the timber after a longer lapse of time loses much in value. 
While a jndieions tapping is not only justified, but demanded, by an eeonomic system of exploitation, the prevailing methods of oreharding are nunecessarily lestruetive.

The tapping of sapling timber not yet ripe for the saw, and the destruetive fires started in eonneetion with this industry, annihilating all young growth, prevent ang renewal of the forest, while the working of large bodies of timber years before inilling faeilities are available leads often to 20 per eent aud more of loss in both quality and quantity of the merehantable produet.

FIRES.

The greatest injury to whieh the pine forests are subjeet in eonsequenee of turpentine oreharding arises from the fires whieh are started every spring for the purnose of getting rid of the combustible matter raked from around the tapped trees in order to protect them from aecidental eonflagrations while they are worked. These forest fires, spreading far beyond their intended limits, destroy entirely the yonngest progeny of the pines, stunt the growth of the more ad vineed trees, and eanse the ruin of a large number of older ones in the abandoned turpentine orrhards. Burning deeply into the gashes and other exposed surfaees of the tapped trees, these fires liasten their prostration by the gales. Moreover, the fire eauses eraeks in the surfaees laid bare by the ax and the puller and oeeasions grenter exposure to atmosplenic action, thus indueing more or less rapill deeay. A test, made by sawing through twenty-two logs taken at random from a turpentine orehard after it had been abandoned for a period of sixteen to eighteen years, showed that about one-half of the timber was partially lecayerl and shaky:

Besiles the prodnction of naval stores as a eanse of forest fires, there is another seareely less potent. This is the praetice prevailing among the settlers of burning the woods upon the approach of every spring in orler to hasten the growth of grass for their famisherl stock. Fires are also frequently started through the earelessuess of loggers and hunters, in the preparation of the ground for tillage, and by sparks from locomotives. These fires, oecurring at least once during every year, eause the total destruction of the young growth of the Longleaf Pine. The dinger to this species is nuch greater than to any other Southeru tree, because of the greater length of time it requires to reach a size at whieh it ean offer some rasistance to fire. In the open forests of Iongleaf Pine the fires are not so destruetive to the larger timber as in the deuse forests of coniferous trees farther north, trees of larger size being, with some exeeptions, hut slightly, if at all, direetly damaged.

Another serious damagre, however, resulting from the frequent reenrrence of fires is the destruetion of all vegetable matter in the soil. Deprived of the mulehing neeled for the retention of moisture, the naturally porons and dry soil, now rendered absolntely arid and barren, is no longer eapable of supporting any larger tree growth or other useful vegetation.

LIVE sTock.

Of no less danger to the existence of the forests of Lougleaf Pine is the injury eaused by live stoek. This ageney, slow in its action, is sure to lead to their destruction nnless restrieted to some extent. Besides the danage due to the trampling down and mutilation of the young growth by herds of eattle roaming through the woods, the smaller domestic animals-goats and sheep-eat the tufts of the tender foliage of the seedlings, while hogs are seen digging up and ehewing the spongy and tender roots of the young plants. As a further ageney in the way of the renewal of this species, the destruetion of the matnre cones might be mentioned, caused prineipally by the squirrels, whieh peel off the seales clean to the eore in seareh of the sweet, nutritious seed.

sтorms.

Full.grown trees are frequently uprooted by the hurrieanes which from time to time pass throngh the pine belt. Those having the taproot shortened by impenctrable layers of indurated elay interposed in the subsoil at varying dejths are invariably the first victims of the high winds. In trees grown in sueh plaees the taproot is found with a tumid and round base as smooth as if polished. 
FUNGI.

Frequently full-grown trees are found to show signs of rapid decay. These are recognizerl by the gradual dying of the smaller limbs and their falling off, in eonsequenee of the rotting of the wood surrounding their base; and after having been cast off a loole or diseased spot remains in the trunk, which is infested by a large fungus of the genus Polyporus (punk holes, punk stools). 'The heartiroof of sueh trees is of a reddish color, soft, sappy, and full of small ehannels, eaused by the breaking down of the walls of the wood cells, filled with the mycelium, the so-called spawn of the fungus, the threads of whieh also penetrate the medullary rays. Sueh punky or red-heart timber is found mostly on the ridges in the poorest soil. Apparently superannuated trees are most frequently found afflieted with this rot.

INSECTS.

The Longleaf Pine, throughout its existence, is exposed to the danger of destruetion by the ravages of insects, hosts of which, belonging to various orders, are found to infest it from the earliest stages of its development. Upon the tufts of the tender primary leaves of the seedling are often found feeding large numbers of a yellow, black-striped caterpillar, the larvæ of a speeies of sawfly (Lophyrus).

The cambium of trees felled in the latter part of the summer is soon found swarming with the larval brood of bark beetles, which after a short time infest the trecs growing near by, eausing, as has been again and again observed, the death particularly of the trees of younger growtli over extensive areas. Hence the neeessity of stopping the praetice of felling trees during the summer season. Aceording to information kindly furnished by Mr. Schwarz, of the Entomological Division of the United States Department of Agriculture, most if not all the species of the bark beetles of the family Tomicida have more than oneannual generation, and in the Southern States they have, in all probability, three. The summer generation develops in a very short time, possibly within four or five weeks, and the perfeet beetles issuing from the trees felled in August will in Septem. ber attack the healthy trees near by for want of more suitable food. The ravages spoken of by Michaux refer, no doubt, to these species of Tomicide beetles which enter the solid wood of trees, e. g., Gnathotrichus materiarius and Xyleborus pubeseens. The galleries of these timber beetles or allicd speeies are found to penetrate the wood to the heart. The grating noise made by the larvie of the large ceramboid beetle, the Monohammus, while engaged in its work of destruetion frefurently strikes the ear in the forest. That there is a large number of species belonging to different orders preying on the Longleaf Pine and more or less destruetive to the life of this tree is apparent from the following eommunieation from Mr. Sehwarz:

The number of insects to be fonnd on the Longleaf Pine is very large and comprises species of most orders, but a complete list of them has never been pablished and the habits of most of them have never been carefully studied. Only those which aro really injurious to the tree need to be considered.

Order Iymenoptera: Several specius of sawflies (Tenthredinide), oceasionally very injurious to the youuger tress, the larvo defoliating the branches. The species thus far observed are Lophyrus abbotii, Leach; Lophyrus lecontei, Fitcli, and three or four less common species.

Order Coleoptera: Ronnd-headerl borers (larvas of Cerambycida) affect the trees similarly to the Buprestida, but their bnrrows are always cyliudrieal, and some species bore only under the bark. The most abundaut aud destructive is Monohaumus tititlator. l'abr., but there ure unuy other specics, of which the following is a partial list: Scaphinusspharicollis, Lec.; Asenum nıostum, Hald. ; Criocephalus nubilus, Lec.; Enpogonius tomen tosus, Hald.; Acanthocinus nodosus, Fabr. In the family Curculionide, tho worst ellemy of the pine tree in the nore Northern States, Pissodes strobi is rare in the region of the Longleaf Pine, bnt another species, I'achytobius picivorus, Germ., the larvas of which bore under tlse bark, is quite common and greatly injurious to the Longleaf Piue. Of its more dangerons enemies the Scolytid beetles, which mostly bore their galleries under the bark, only a fow species entering the solid woorl, the following are known to infost Pinus palustris: Pityophthoruspulicarius, Zim.; P. annectens, Lee.; Tomicus calligraphus, Ger.; T. avulsus, Eich.; T. cacographus, Lec.; Crypturgus atomus, Lec.; Dendroctonus terebrans, Oliv.; D. frontalis, Zirn.; Hylastes porcutus, Er.; H. exilis, Chap.

The few species en tering the solid wood are Platypus quadridentatus, Oliv.; Gnathotrichus materiarius, Fitch, and Xylebor" pubescens, \%im. Most of these Scolytidie are extremely unmerous in specimens, and al though they nonally infest zrujnrerl or diseased trees, jet in cases of excessive unultiplication or for want of proper food they often attack healthy trees, which within one or two years succumb to their attacks. 
NATURAI, REPRODUCTION.

Certain peculiarities inherent to this species form a series of obstacles in the way of its spontaneous reproduction. These are, first, the rare oceurrenee of seasons of abundaut erops of seed, and, sceond, its slow growth during the earliest part of its development, rendering the young offspring of this pine liable to be suppressed by eompeting species of rinicker growth. To these canses is to be further added its dependenee upon the influenee of direet smight, whieh is required for its germination as well as during the subsequent stages of its growth to inatırity, and the sensitiveness of the seeds and seedlings to moisture; placed in a wet, nndrained soil, the germinating power of the first is destroyed and the latter will perish on exposure to the same eonditions. A study of the young growth of the Longleaf Pine over the different regions of its habitat leads unavoidably to the conclusion that the ehances for the reproduction of its forests, left to the ordinary course of nature, are qnite limited, even if the adverse conditions arising from human agencies are left out of consideration. On the lowlands of the Atiantie Coast toward its northern limit this pine is almost invariably replaced by the Loblolly Pine, while farther south and in the coastal plain of the Gulf States east of the Mississippi River, after its removal, it is replaced partly by the Loblolly Pine and largely by the Cuban Pine. On the wide expanse of nplands rising above the coastal plain with their broad ridges of a soil of sandy loam, the young trees of the Longleaf Pine are net with in every stage of growth. Attaining, lowever, during the first five or six years scareely a greater height than the surrounding herbage, the seedlings are irredeemably rnined by the various destruetive agencies to which they are exposed. On land liable to repeated conflagrations, a serublyy growth, chiefly of barren oak and other upland oaks alrealy mentioned, takes possession and exehdes by its shade the pine. If upon the rolling pine lands or dry pine barrens the removal of most of the original tree covering is followed by a succession of barren years, the ground will surely be invaded by the lıard-wood trees mentioned, which will retain possession. Under the shate of these trees the Longleaf Pine can never again find a home. In the stronger soil of the mpper division of the maritime pine belt, the region of inixed growth, where the seedlings of the Longleaf Pine spring up simnltaneously with the hard wood trees and the seedlings of the Shortleaf Pine, these latter will eventually gain the supremacy and suppress those of the Longleaf Pine; consequently the latter is seldom observel in mixed forests of seeond growtl. In the flat woods, particularly in the pinc flats of sonthwestern Lonisiana and Toxas, with a soil water-soaked during the winter and spring, the of spring of the Longleaf Pine is still more rarely met with for the reasons stated. From these facts it is evident that, owing to natural canses, combined with the unrestricted sway of the influences leading to its destrnction by humau ageney, the offspring of the Isongleaf Pine is rarely seen to oceupy the place of the parent tree, even in the region most favoruble to its natnral renewal, and that final extiuction of the forests of the Longleaf Pine is inevitable nuless proper forest management is applier.

\section{FOLEST MANAGEMENT.}

The time for the acquisition of timber lands or of the right of working them for their produets at prices far below what eould be considered as an alequate return for their instrinsic value has well-nigh passed away. The opportmuities which existed during the last twenty-five years for aequiring Longleaf Pine lands, which were open to purehase by the liundreds of thousands of aeres have now in a great measure ceased to exist. The greater part of this kind of property has passed into the possession of eapitalists, and the rest will soon be sinilarly controlled. Under this new order of things the price of these timber lands is gradually approaching figures more in proportion to their true value. The depredations committed unblushingly on the public lands, and on the lands of railroad corporations and private owners, are renclered less easy every year under a mutual protection of interest. Reckless waste and devastation, heedless of the interests of the future, are giving way to a more econonieal management of the timber resourees in the loggiug eamp and in the mill. No measures have been attempted to maintain these resonrees by sparing the younger timber in its best stage of growth from the ax, or to provide in any other way for the protection and preservation of the younger growth. 
What has been said of the geograptieal distribution of this tree and its demands upon elimate, soil, and exposure demonstrates that east of the Mississippi River it ean be suecessfully grown all over the maritime plain of the Southern States (Austro riparian zone) and in the interior of Alabama, throngh a large region of the Carolinian and the southern extension of the $A$ ppalachian zone to an elevation above the sea falling little short of "2,000 feet. And the sanrly soils of this region, largely too poor for agrieultural use, are par excellence Longleaf Pine lands. In the renewal of the forestsof Longleaf Pine, upon areas denuded, the fact mnst le borne in mind that to prodnce timber whieh is muler present conditions considered of fuir merchantable pluality a period of not less than one hundred and fifty years is required, and that to prodnce timber of the dimensions, elearness, and clurability for whieh it is held in such high esteem the slow growtl under the severe and hardening eonditions involved in the struggle for light in the erowded forests is neessary. Henee, economic reasons wonld point to the maintenanee and conservative mantigement of the existing forests of Longleal' l'ine and their renewal by natural reproduction, and preferably by the method of selection which under the present conditions appears the most praetieable, involving chiefly methods of protection.

By this method all or most of the mature trees, eorresponding in their proportions to the most desirable quality of timber, are eut and the rest left to grow till they reaeh similar dimensions, to be in their turn replaeed by the seeond growth, which in the openings from time to time springs 11p. In faet, this method was followed in the earlier days of the timber industry in the several regions of the Longleaf Pine, where the forests were being culled for the best sizes at intervals of from fifteen to thirty years. But owing to the exhanstion of the inature pine from forests within reaeh of railroad lines and water eourses, which necessitates great outlays of enpital for construeting tramroads or waterways, the original practiee of selection has been abandoned, no tree being spared at present that will make a stiek of timber, however small, as long as it fincls a sale in the market. Care should of eourse be taken to leave always enough seed tress evenly distributed, and the chief eare is to be directed to the protection of the seedlings and other young growth from the destructive ageneies mentioned-fire, eattle, and the eneroach. ment of invading species. A forest under such management would neeessarily present a great liversity in the growth of the trees, and the length of time between one cutting and the next womld be equally variable. It must be remarked that the demand of this species for the unhindered access of direet sunliglit during the time of germination and sneessive stages of growth miglit prove a serious obstacle to the eontinued success of this method of seleetion; and the "group methorl," as describerl in the report of the elief of the Division of Forestry for 1894, might be substituted with advantuge. Where it is desired to reestablish the growtlı of Longleaf Pine upon demuled areas, the ground must be cleared of every obstacle in the way of free access of the rays of the sun before the sowing. Owing to the ease witl whieh the seeds germinate and the seerllings talie root in the gromid, but slight preparation of the same would be required, and there would be no dificulty in procuring a good stand. If transplanting is to be resorted to, the seedlings should be taken up during the fill or winter suceeeding the first season of their growtl, before the further development of the rapidly growing taproot, the preeaution always being taken to prevent any injury to the rontlets and their drying ont before their transfer to the gromul. Since the trees clear themselves easily of branches, the stand in the plantation in the earlier stages does not need to be as dense as with other speeies. In order to seenre improvement and permanency of favorable soil conditions, the litter from the shedding of the leaves and gradual lecily of herbage should be left undisturbed on the ground.

There can be hardly any doubt that the intreduetion of other shady speeies wonld greatly assist in improving soil conditions and produeing more rapicl development of the pine. Care wonld have to be taken to bring in these species later, say between fifteen and twenty years, when the pine has begnn to make its rapid height growth and ean escape the shade of its neighbors.

For the present, however, the economic conditions are hardly yet ripe for any artifieial reforestation, hut the great importanee of this valnable forest resource to the industrial and conmercial development and prosperity of the people living within its linits should be apparent enough to keep them at least from preventing its natural reproduction. The growth of the young timber after the first few years is rapid enougl, as may be seen from the table on page $5 \bar{i}$, and $7093-$ No. $13-5$ 
after fifteen or twenty years, when the trees have reached a diameter of 12 inches, they cau be tapped for resin and will give a eontinuous revenue. Under eareful management, and by tapping only the trees which should be removed in thinnings to make light for the rest, this reveme ean be obtaned withont in any way impairing the final harvest value.

\section{CONCLUSION.}

From the southern frontier of Virginia, throughout the lower part of the Southern States, to the limits of high and eompact forest grow th west of the Mississippi River, spread over an area of from 90,000 to 100,000 square miles, the forests of the Longleaf Pine still present a stupendous tim. ber wealtl. Yet, if we deduct the farm lands, and eonsider that large areas have heen eulled or entirely denuded of the original growth, we may estimate that the amount of timber standing can at best not exeeed $100,000,000,000$ feet, and is probably mneh less, while the cut, whieh at present does not fill short of $3,700,000,000$ feet, board measure, is bound, as the Northern pine is giving out, to increase at even greater rate than in the past. Under sueh a strain, outstripping by far the possibilities of their reprodnetion, the exhaustion of the resonrees of these forests within the near future is inevitable, and if the devastation under present managenent by the naval store industry and the destruetion eaused by fire and domestie animals is eontinued their extermination as far as praetical purposes are eoneerned must be regarded as equally eertain. 


\section{APPENDIX.}

\section{THE NAVAL S'TORE INDUSTRX.}

The resinous product of the Longleaf Pine furnishes the raw material for the production of naval stores, one of the most important inclustries iu connection with the resources of the American forests. At present the bulk of these stores used in the world is derived from the forests of Lougleaf Pine, and hence this industry is almost entirely confined to the coast pine belt of the Southeru States, the proportion contributed by France, Austria, and other countries being insignificant.

For the year 1892 the foreign export of spirits of turpentine alone amounted to over 260,000 casks and the total production exceeded 350,000 casks. To produce this amount of spirits at least $2,500,000$ acres must have been in orchard, and since over oue-third of the total production is furuished by orchards being worked for the first year, over 800,000 acres of virgin forest must be attacked annually to supply present demands.

Under the name of naval stores are comprised the products derived directly or indirectly from the resinous exudation of cone-bearing trecs, nostly pines, including tar, the product of the destructive distillation of the wood of pines highly charged with resinous matter. The name is undoubtedly derived from their extensive consumption in the shipyards and on board of vessels. 'These products are:

IESIN, OR CRUDE TURPENTINK.

The resin of the Longleaf Pine recently exuded is almost colorless, or of a pale straw color, of the consistency of honey, having a terebinthinous odor and taste, and like all substances of the same class is insoluble in water, but soluble in alcohol, ether, and spirits of turpentine. It con. sists of a volatile oil and a solid resin held in solution partially suspended in the former. The best quality is obtained during the first ycar the tree is worked, known as "virgiu dip" or "soft white gum," which is almost colorless and contains the largest quantity of volatile oil. In the following year it is of a decper yellowish color, the "yellow dip," which with each succeediug year becomes darker in color, more viscid, and poorer in volatile oil."

Toward the close of the season the resin becomes hardened under the influence of a cooler temperature and the partial evaporatiou of its volatile constituents. This soliditied resin, of whitish to ycllowisl color, called hard gum or scrape, contaius ouly half of the quantity of the spirits of turpentine obtained from the dip or soft gum. By the distillation of the crude turpentine the naval stores of most importance to trade are obtained.

SPIRITS OF TUIPENTINE, OR OIL OF TURPENTINE.

Spirits of turpentine, or oil of turpentine, is the volatile constituent of the resin. This liquid when freshly prepared is colorless, of a peculiar odor and taste, of a density varying betwcen 0.85 and 0.87 , volatile at orlinary temperatures, boiling betwcen $304^{\circ}$ and $320^{\circ} \mathrm{F}$. It turns polarizel light to the right, a characteristic feature of the American spirits of turpeutiue, most of the spirits from other sonrces polarizing the light to the left. In its pure state this volatile oil is free from oxygen, being a liyilrocarbon of the composition of $\mathrm{O}_{10} \mathrm{H}_{16}$. It is highly iuflammable and

'It is still an npen question whether this desterioration is necessary or only owing to faulty manipulation. Experiments to settle this question are now in progress in the Forestry Division. 
burus with a sooty flame. It is a good solvent for many resius, wax, fats, caoutchouc, sulphur, and phosphorus, and is nsed in the arts and industries for the preparation of varuishes, in paints, tlie rubber indnstry, ete. Before the introduction of kerosene oil it was nsed extensively for an ilimminator; it is also used in medieine internally and exterually and often as an adulterant of various essential oils.

ROSIX, OR COLOPHONY.

The solid constituent of the crude turpentine which forms the residne remaining after its distillation. It is of different degrees of heaviness, neeording to the quantities of volitile oil retained atter distillation, is brittle, easily powdered, of a glassy luster, and of the specific gravity of 1.0i, ahmost without taste, of a faint terebinthinous odor. It beeomes soft at about $176^{\circ} \mathrm{F}$., melts between $19.4^{\circ}$ and $212^{\circ} \mathrm{F}$., and is soluble in the same solvents as crude resin. According to the natme of the ernde turpentine, depending upon the number of seasons the trees lave been worked, it shows different properties in regard to the transmission of light, and in color. It is either perfectly transparent, transineent, or almost opaqne; almost colorless, or a pale stina color to golden yellow, reddislı yellow, throngh all shades to dark brown and almost black. The market valne of this article is eutirely regulated by these properties. In the Ameriean marliet the following grades are distinguished: WW (Water White) and WG (Window Glass), the lightest and highest prieed grades, obtained fiou the "virgin dip;" N (Extra I'ale), II (P'ale), K (Low Pale), I (Good No. 1), II (No. 1), I (Good No. 2), E (No. 2), D (Good Strain), C (Strain), B (Common Strain), and A (Blaek).

PINE TAR.

This is not exactly a by-product of the turpentine orehard, but is produeed by the destructive distillation of the wood itself. It is chiefly produced in North Carolina, where this industry lias been carried on since the earliest eolonial times. Small quantities are produced in other sections of the Southern pine belt, mostly for home eonsumption. Perfectly dry wood of the Longleaf Pine, dead limbs and truuks sensoned on the stmmp, from which the sapwood has rotted, are cut in suitable billets, piled into a conical stack, in a circular pit, lined with elay, the center commnnicating by a depressed channel with a receptacle-a hole in the gronnd-at a distance of 3 to 4 feet from the pile. The pile is covered with sod and earth, and otherwise treaterl and managed like a eharcoal pit, being fired from apertures at the base, giving only enough draft to maintain slow smoldering combustion. After the ninth day the tar begins to tlow and eontinues for several weeks. It is dipped fiom the pit into barreh of 320 ponnds, the standard weight. One cord of dry "fat" or "lightwood" furnishes froin 40 to 50 gallons of tar. The priee of pine tar is quoted as low as \$1.05 a barcel. Since considerable quantities of tar are produced ineidentally in the destructive distillation of wood in iron retorts for charcoal and other prodnets, the price has been greatly depressed.

COMMON PITCH.

The best quality is obtained by boiling down tar until it has lost about one-third or more of its reight. The naval pitch of commeree has unore or less rosin of the lowest grade adderl to it. Pitch is also obtained as the residue remaining from the dry distillation of rosin for rosin oil.

HISTORICAK, BEMARKS.

The tapping of the trees for the crude turpentine and the manuficture of tar aud pitch was first resorted to by the enrliest settlers of Nortl Carolina, and in later colonial times these products furnished the largest part of the exports of the colony. In the three yens from 1768 to 1760 the exports of crude tinentine, tar, and piteh represented on the average for each year a value of $\$ 215,000$ of our present eurency. Most of the crude turpentine was shipped to England. Later the distillation of spirits of turpentine was carried on in elumsy iron retorts in North Carolina and in Northern cities. The introdnetion of the copper still in 1834 resulted in a largely inereased yield of spirits of tnrpentine, and the ind ustry received a great inpetus. With the new demand for spirits of turpentine in the manufactmo of rubber goods, and its increased nse as an illuminator, the number of stills inerensed erreatly, and turpentine orcharding was rapidly extended south and west beyond its original linit. The large consumption of spirits of turpentine 


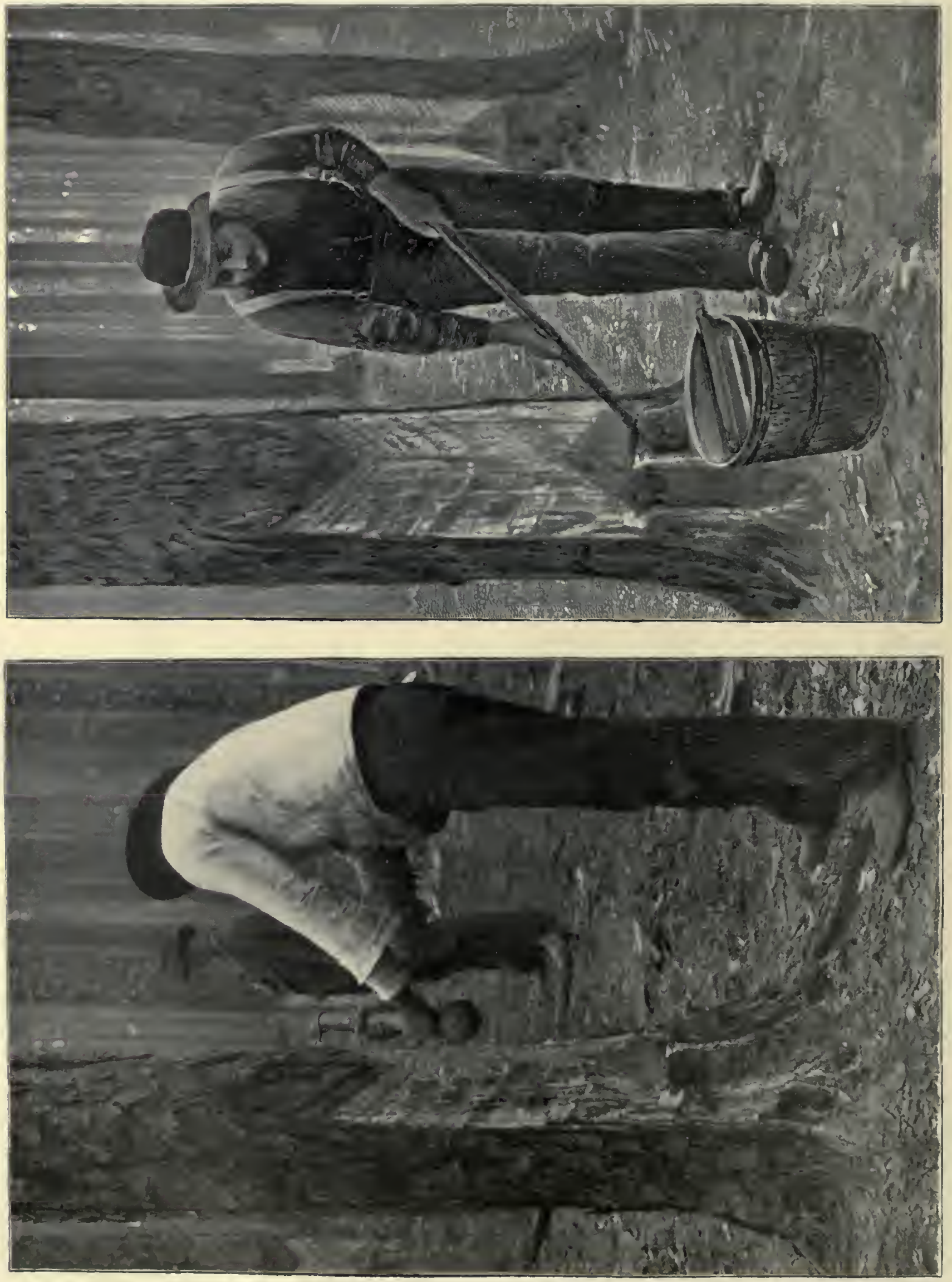
causer sueh an increase in its production that the residnary product, rosin, beeame largely in excess of the demand, and, in consequence, much depreciated. This rednetion of profits in the bnsiness caused the transfer of the stills from the leading inarkets to the source of the raw material, the forest. From that time, 1844, dates the great progress made in the extcusion of this industry. Up to that time more than half of the crude turyentine was distilled in North Carolina, but thenceforth the indnstry spread into the States of South Carolina, Georgia, Florida, and the Gulf States to the Mississippi River.

At the close of the war the lemand for spirits of turpeutine was not so great as before, petruleum jroducts of several kinds having been found to take its place not only for illuminating, but also for other purposes. With the general extension of arts and manufactures all over the world, there lias since been an increasing demand for spirits of turpentinc and rosin. The cxports of these articles in the year 1890 amounted to $\$ 8,135,339$ in value.

TURPENTIXE ORCHARDING IN TIF HORJSTS OF IONGLEAF JINE.

In tlıe cstablishment of a turpentine orchard and a still, two points inust be eousidered, unnely, proper facilities of trunsportation to shipping points aud a suffieient supply of water for the condenser connected with the still. The copper stills generally in use have a eapacity of about 800 gallons, or a charge of 20 to 25 barrels of crude turpentine. For such a still to be charged twice in twenty-fonl hours during the working season, 4,000 acres of pine land of a good average stand of timber arc requircel. This a: ea is divided into twenty parcels each of 10,000 boxes, as the receptacles are called, which are ent into the trec to receive the exuding resin. Sueh a purcel is termed a crop, constituting the allotment to one laborer for the task of chipping. The work in a turpentiue orchard is started in the carlier part of the winter with the cutting of the boxes. Until some ycars past no trees were boxed of a cliameter less than 14 inches; of latc, however, saplings under 10 inclies in dianeter are boxed. Trees of full growtl, according to their eircumferenee, receive from two to four boxes, so that the 10,000 boxes are distributed among 4,000 to 5,000 trees ou all area of 200 acres.

The boxes are cut (see Pl. VIII) from 8 to 12 inches above the base of the tree, 7 inchcs deep and slanting from the outside to the interior, with an angle of about $35^{\circ}$. 'In the adnlt trecs they are 14 inebes in greatest diameter and 4 inehes in greatest wiltl, of a capacity of about 3 pints. The cut above this reservoir forms a gash of the same depth aud abont 7 inches of greatest height. In the meantime the gronnd is laid bare aronnd the tree for a distanee of 22 to 3 feet, and all combustible material loose on the ground is raked in heaps to be burned, in order to proteet the trees against clanger of catehing five during the conflagrations whielı are frequently started in the pine forests by design or carclessuess. The employment of fire for the protection of the tmrpentine orchard against the same destruetive agency uecessarily involves the total destruction of the smaller trce growth, and if left to spread without eontrol bcyond the proper limit, often earries ruin to the arljoining forests.

D'ring the first days of spring the turpentinc begins to flow and clipping is begun, as the work of scarifiention is termed, by which the surfice of the trce above the box is laid bare beyond the youngest layers of the wood to a depth of about an inch fiom the ontside of the bark. 'The removal of the bark and of the outermost layer's of the wood-the "chipping" or "hacking"-is done with a peculiar tool, the "liacker" (fig. 9,,$f f$ ), a strong knife with a curved edge, fastened to the end of a handle bearng on its lower end an iron ball abont 4 pounds in weight, to give increased force to the stroke inflicted on the tree, and thus to lighten the labor of chipping. As whon as the scarified surfiec ceases to discharge turpentine freely, fresh incisions are made with the hacker. The chipping is repeated crery week from March to Oetober or November, extending generally over thirty-two weeks, and the height of the ehip is increased abont $1 \frac{1}{2}$ to 2 inches every montlı. The resin accunulated in the boxes is dipped into a pail by a that trowel-shaped dipper (fig. 9, a) and then transferred to a barrel for transportation to the still. In the first season from six to right dippings are made. The 10,000 boxes yield at cach dip 40 barrels of "dip" or "solt gum," "as it is reckoned in Alabama, to be of 240 pounds net weight. The flow is most eopinus chring the height of the summer (July and August), diminishes with the alvent of the coolcr scason, and ceases in Oetober or November. As soon as the exudation of the resin is arrested and 
the resin berins to harden mnder the influence of a lower temperature it is earefnlly scraped from the searifled surfiee and tho boses with a narrow, keen.edged knife attaelied to a long wooden handle (fig. 9, b, c). In the first season the average yield of dip amonnts to 280 harrels and of the hard gnm or scrape to 70 barrels. The first yields $6 \frac{1}{2}$ gallons spirits of turpentine to the barrel of 240 poumds net, and the latter 31 ponnds to the barrel, resulting in tho produetion of 2,100 gallons spirits of turpentine and 260 pounds of rosin of higher and lighest grades. 'The dippings of the first season are called "virgin dip," from which the finest quality of rosin is obtained, graded in the market as Water White (WW) and Window Glass (WG). In the second year from five to six dippings are made, the crop averaging 225 barrels of soft turpentine and 120 barrels of seraje, making altogether abont 1,900 gallons spirits of turpentine.

The rosin, of whieh alout 200 burrels are prodneed, is of a lighter or deeper amber eolor, and preffectly transparent, of mediun quality graded as I, H, and G. In the third and fonrth years the number of dippings is redneed to three. With the flow over a more extended surface, the turpẹtine thickens nnder prolonged exposure to the air and loses some of its volatile oil, partly by evaporation and partly by oxidation. In the third season the dip anounts to about 120

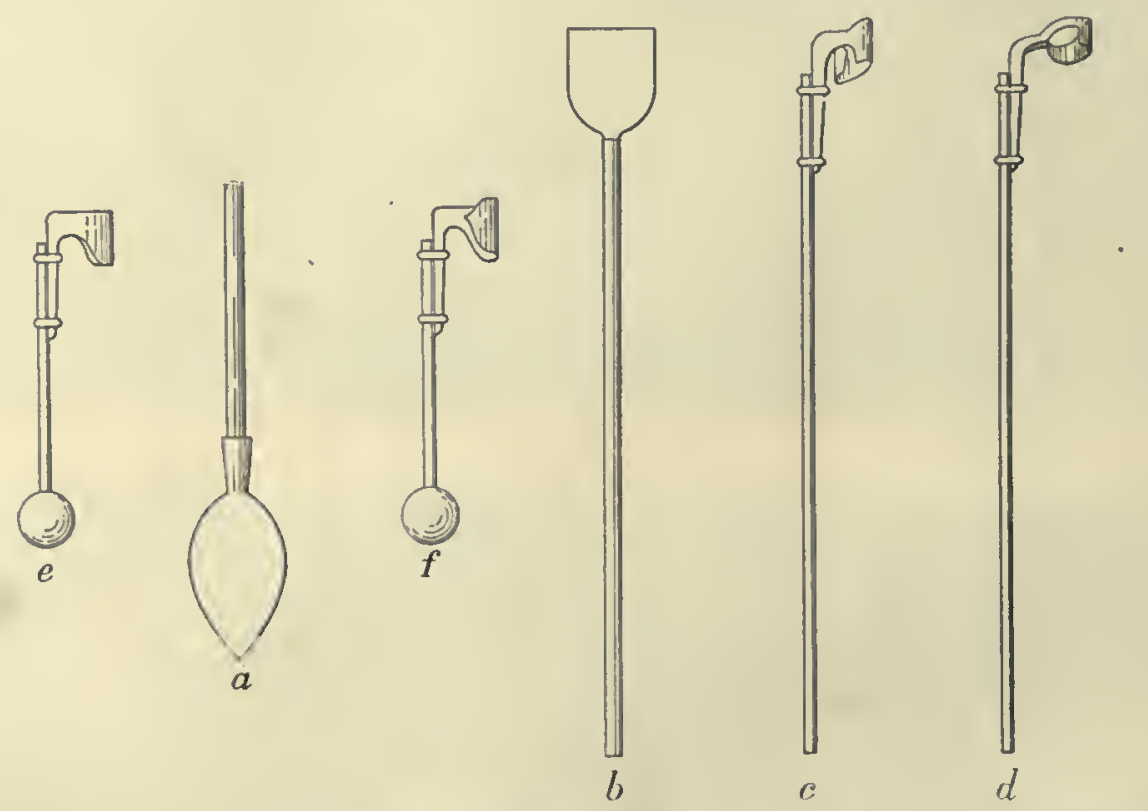

F10. 9.-Tools used in turpentine orchurding: $a$, dipper; $b$, pusher; $c$, open puller; $d$, closed puller; $c_{0} f$, lacker (front and rear view).

barrels and the sernpe to about 100 barrels, yielding about 1,100 gallons spirits of turpentine and 100 barrels of rosin of a more or less dark eolor, less transparent, and graded as $\mathrm{F}$, E, and I). In the fonrth and last year three dippings of a somewhat smaller qnantity of soft turputine than that obtained the season before and 100 barrels of serape are obtained, with a vield searcely realizing 300 gallons of spirits of tnrpentine and 100 barrels of rosin of lowest quality, classed as C, B, and A. After the fourth year the turpentine orehard is generally abandoned. Owing to the reduetion in quantity and quality of the raw prodnet, it is not considered profitable by the larger operators to work the trees for a longer time. It is only in North Carolina that the smaller landowners work their trees for ten or more suceessive seasons, protect the trees against fire, and after giving them rest for a series of years, apply new boxes on spaces left between the old ebips"reboxing."

Distillation.

The proeess of distillation is earried on in the ordinary way, and reqnires eare and experience to obtain largest yuantities of rosin of highest grade and to guard against overheating. After heating the still, somewliat above the melting of the crude turpentine, a small stream of tepid water from the top of the eondenser is conducted intu the still and allowed to run until the end of the process. A large quantity of water rnus over with the spirits of turpentine, whieh is 
collected in a barrel, where it separates from the water and is then immediately transferred into barrels. After the oil has eeased to rmn freely the heating of the still and the inthix of water has to be carefnlly regnlated. After all the spirits of turpentine has been distilled over, the fire is remover and the contents of the still are drawn off by a tap connected with the bottom. 'This resilnum, molten rosin, is at first allowed to run through a wire cloth and is immediately strained again through eoarse cottou cloth or cotton batting, made for the purpose, into a large trough, from which it is ladled into barrels. The legal standard weiglit of the eommercial paekage is ¿s0 ponnds gross. A turpentine distillery on the basis of twenty crops produees on the average Inring the fonr years that the boxes are worked 2,400 casks or 120,000 gallons of spirits of turpentine and about 12,000 barrels of rosin or 2,800,000 pounds, the lowest grades, B and A, excluded, a total valne of abont $\$ 60,000$ at average priees. The prices of spirits vary at present from "28 to 40 cents a gallon, even through the same season, aeeording to supply and demand in the market. The average quotations on December 30,1892, at Wilmington were 28 cents for spirits and $\$ 1.91$ for a barrel of rosin down to grade $\mathrm{C}$.

Cost of EstaBlishing a PLANT AND WORKING THE CROPS.

Timber lands with the privilege of boxing the timber for a term of four years are rented at the rate of 850 per crop of 10,000 boxes, or 200 acres. The establishment of a plant for the working of twenty crops, or 4,000 aeres of timber land, requires an investment of about $\$ 5,000$, ineluding the buildings, stills, machinery for pumping water, tools, and teams. According to the statements of an experienced operator, the cost of working the trees of one crop during the four years, which is mostly dome by the job-that is, the making and cornering of the boses, inspecting the same, raking aromd the trees, chipping, dippmg, seraping, laauling the crulc tnrpentine to the still, inclnding cost of barrels for spisits of turpeutine, and for the rosin and superintending the crop-amounts to abont $\$ 2,300$ per erop, or $\$ 46,000$ for the twenty crops. If to this amonnt the interest, 6 per cent per anum, on the capital invested and the depreciation in the value of the plant during the four years is adderl, with some other incinlental expenses (taxes, etc.), the cost of the production of the 120,000 gallons of spirits of tnrpentine and 12,000 barrels of merchantable rosin, foots np to not less than $\$ 50,000$.

A method of improving on the present praetice by employing an earthen pot instead of the injurious "box" has been patented and practically introdnced by J. C.

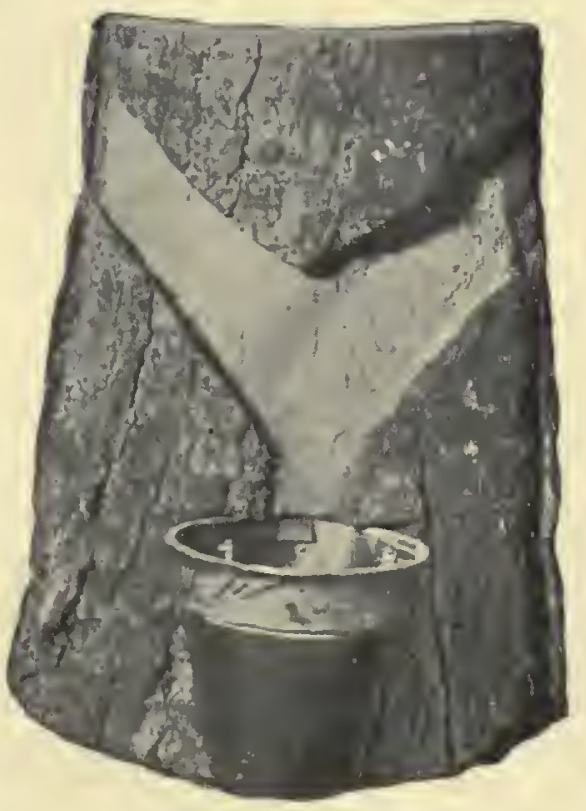
Solnter, of West lake, Lil. The arrangement is repre- Fig. 10.-Inproved method of turpentine oreharding. senterl in fig. 10, its main feature being an earthen pot whiclı can be moved as the scar is lengthener, thus redncing the distance over which the resin las to thow, and with this the amomt of rolatilization and loss of spirits of tnrpentine. The methor resembles that employed in France (see Report of Chief of Forestry, United States Department of Agricnlture, 18!2, lage 347), and, thongl its general application in this conntry is not yet secnred, it is certainly a step in the right direction.

Мr. Schnler almits that the first cost for providing the enps, putting them up, and removing them the second season raises the expense of working a crop of 10,000 enps for two seasons to $\$ 460$, against $\$ 190$ for entting 10,000 boxes expenderl umler the old systen in working one crop for two seasons, all other expenses comected with the work being considered equal: On the other hand, Sehnler clains that the difference is vastly overbalanced by the increased yield of ernde turpentine sbtained by lis cup method, amounting for one erop worked two years to 195 barrels, at $\$ 3.50$ per barrel; after dedueting the extra expense involved by his method, this wonld leave a net balance of $\$ 410$ per crop in favor of the enp system. He also claims that this amomut is still finther angmented if the larger (puntity of spirits of turpentine and the highel quality of resin obtained 
from the dippings muler his system are taken into account. On the first point he says that fully one-eighth of the crude turpentine brought to the still from the boxes consists of chips, sand, and other foreign matter, contuminations from which the product of the cups is entirely free. On the second point he refers to the high grades of rosin resulting from the distillation of the crude turpentine from the cups, which almost entirely classes with the highest and higher grades.

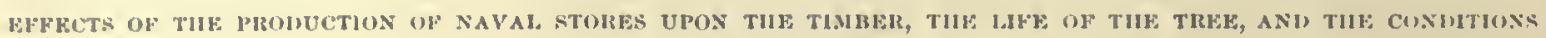
OF THI FOLEST.

In the present management of the tmpentine orchards in the Southern pine forests a great deal of erude turpentine is wasted, much of the valnable spirits of turpentine is lost by volatilization in passing over the long chip face on its way to the box, and innch of the resin is lowered in its grale and value by oxidation consequent to exposure and by admixture of foreign substancesbark, coal, dust, ete.

Concerning the ellect of the tapping of the trees upon the timber, there exists un reason on physiological or anatomical grounds for considering it injurious, and the opinion held by many, that the qualities of timber are impaired by bleeding, finds no support when it is considered that the heart woorl remalns unatfected. 'The resinous contents of the heartwood being solidified and the formation of the resin taking place only in the newly formed wood, the heartwood can not participate in the flow of the resin, the discharge being necessarily confined to the sapwood. This fact has been fully substantiated by the work of the Division of l'orestry, by which it las not only been shown that the strength of the heartwood, the most important if not the only part of the tree used for lumber, has in no wise been diminished, but also that the durability of the timber, as far as it depends upon its resinous contents, can not be impaired by bleeding. It is only in that part of the butt $\log$ around the chip that the quality of the timber becomes somewhat inpaired-the wood becoming highly charged with resin is rendered more brittle and harder to work, with a tenlency to gnm up the tools. Indirectly, however, a considerable proportion of the boxerl timber becomes damagerl if not ntilized shortly after having been bled. It is often left standing for a number of years, exposed to varions destructive agencies, such as insects and fire, followed ly. parasitic fungoil growth. Large eapricorn bethes bore their way through che callus surrounling the chip and throngle and beyoud the sapwood. Through the innmerable fissures which are cansed by fires, air and wa'er charged with the spores of parasitic fungi find entrance to the body of the tree, causing disease and decay. The damage from these causes increases every year, so that from them alone the timber from a turpentine orchard abaldoned for a dozen years was fouml damaged to the extent of fully 20 per cent. Although the loss of its resin by bleeding results physiologically in no direct injury to the tree, the wound inflicted by tapping, like any other wound, interferes with its healthy growth and, partieularly in the ease of trees of smaller si\%e, cunses their carly decay. While the exuded resin covering the excoriated surface of the tree acts as an eflicient antiseptic, affording a firm protection against the access of the spores of fungi, it endangers the life of the tree, if exposed to fire, by its greater inflammability, the heat produced by its flame being capable of killing the trees outright. In the boxes, all of the trees of smaller size and many of the larger trees are blown down, and in considerable number of those remaining with their excoriated surfaces out of proportion to the recuperative power of the trees are dooned to perish sooner or later in consequence of such treatuent.

These injuries inflicted mpon the individual trees, in connection with the fires started with the opening of the senson one year after another, cause such damage to the forests as to (ffect finally: their total destruction. Fire being allowed to sweep over large areas, its force increased in the turpentine orchards by the exposed resinous surfaces of the trees, and by trees blowil down and the débris covering the gromnd, an inmense amount of timber is destroyed. Trees which have not been killed outright by the fire, or liave altogether escaped the danger, are doomed to speedy: destrnction by bark beetles and pine borers, which find a breening place in the living trens prostrated by the winds during the summer, the broods of which rapidly infest the stanling trees, which invariably sncenmb to the pest the same season. In conseruence, the forests iuvaled by turpentine orcharling present, in five or six years after they have been abaudoned, a picture of ruin and desolation painful to beholn, and in view of the destruction of the seedlings and the younger growth all lope of the restoration of these magnificent forests is excluded. 


\section{LONGLEAF PINE IN IIGHLANDS.}

Under date of August 5,1896, Dr. Mohr sends the following interesting note descriptive of a tract of Longleaf Pine grown at the remarkable altitude of 2,000 feet:

In my investigations of the tlora of the region of greatest clevation in Alabama I was surprised to fund the Lougleaf l'ine, which forms the greater part of the tree grow th on the flanks of tho mountains in the region of the State, to ascend to a beight of 1,600 to 1,700 feet above the sea-(Chenawhaw Mountain, Clay County, 2,400 feet). Whereas I found the tree to risappear at an elevation of about 1,500 feet on the 13lue Monntain or Talladega Mountain Range about Chaudler's Spring, Talladega Connty, and on the isolated ridges of the Alpine Monntains in the saute county (in 1893), Prof. E. S. Smith aud Mr. Brewer, assistant geologist, found at points of the same uountain range, 5 or 6 iniles farther to the south, the Longleaf Pine at an elevation little sliort of 2,000 feet.

Frow my olservations in former years I was eonvineed that the pine forests of the metanorphic regions of Alalama deserved no mention among the timber resonrces of the State, however valuablo they might be as a resouree for fuel in eonnection with the nineral resourees of these parts of the State. I was not a little surjurised to liear, on my trip of last week, of a sawmill with a daily outpnt of from 65,000 to 70,000 feet of lumber of Lougleaf Pine, sitnated in the lower part of Clay County, at the outskirts of the geologieal formatiou mentioned. Yesterday morniug I visited the pine forests from which the supplies of this large and well-eonducted estallishment, at Iollius, on tlie Georgia l'acitie Railroad, are drawn. There I found the foothills and narrow valleys between them, at an elevation of from 1,400 to 1,500 feet, eovered with a truly magnificent forest of Pinus palustris, yielding to the aere as much merehantalle timber as the best ' lass of pine lands in the eoast pine belt from Alabama to Texas. The trees aro tall; solne of them measnred on the ground were found from 110 to 118 feet total height, with the crown 60 feet alove the gronud, and the shaft clear of heart and limb for almost the whole of that leugth; two euts of 20 feet eaeh above the stump a re geuerally free from blemish. The surfaee soil appeared as arid and poor as that fomm on the steep deelivities of the main rauges. Its pine timber growth was to me indeed an enigma, which, however, soon fonnd its solntion by examiniug in a deep 'ut the subsoil eonditiou; the deeomposed dioritie sehist, forming a kind of soft marl for a great depth, offered uo ohstaele to the loug taproot of the pine. These hills exteud for a leugtb of about 6 miles in a northensterly direetion, by a width seareely exeeeding 2 uniles. I eould uot learn that any other locality is found in the same geological formation of an equal extent with the same eonditions of the timber growth. 


\title{
ADDITIONAL NOTES ON LONGLEAF PINE.
}

\author{
By FLLEIRT Roth.
}

(September 1, 1897.)

Though this speeies is well recognized wherever it grows, and receives almost universally the nane of Longleaf or Longstraw Pine, the two terms "Yellow Pine" and "Pitch Pine" are often eonfusing. Unfortunately these names are most eommon at the points of manufacture and with men who know but little about the trees themselves. Wherever nsed knowingly the term "Yellow Pine" refers to very old slow grown trees of Longleaf, with a very fine, smooth bark, extremely tine grain (uarrow rings), and with very narrow sapwood (1 ineh or less). The term "Piteh Pine," on the other hand, refers to yonnger trees, of more rapid growth, wider sap, and consequently with more pitelı or resin. It is self-evident from this that, as these trees grow older, intermediate forms oecnr to whiel one man gives one name, the next man another.

In its distribution the Longleaf presents some very interesting features. In North Carolina, on the north side of the Albemarle Sound, this tree is freqnently wanting over large tracts, and then again eovers several hundred aeres almost to the exclnsion of other pines. Along the western coast of Florida it goes as far south as Fort Myers, on the Caloosahatehee River, eomes right up to the salt marshes or bluffs, with but a slight fringing of Cnban and P'ond Pine, except in the few enses where large hammock swamps like the Gulf Hammoek and Chessahowitzka Swanp oeenpy the spaee between pinery and oeean. In Texas the Longleaf' is ratler sharply limited, ancl the transition is very abrupt from Longleaf Pine forest into a pinery of Loblolly and Shortleaf mixed with hard woods.

As mentioned in the nonograph, the dimeusions to which the tree grows do not vary greatly in different seetions from East to West. There are jnst as fine trees in North Carolina as oecnr in Georgia or in Lonisiana and Texas. An exeeption to this oeenrs in the ease of the extremely barren, dry sands of Florida, where this tree eommonly attains a height of searcely 60 feet, with abont 25 to 35 feet of $\log$ tiuber. Frequently thousands of trees are seen on a seetion with a total heiglit of less than 50 feet, and the top flattened, resembling more that of river-bank eypress than pine. In justiee to this pine, however, it must be said that what it laeks in size it fully makes up in quality, for there is no finer-grained, heavier, and stronger pine in the market than is cut on these pine sand barrens of Florida. Strange to say, even on these dry and barren sands the development or the growth of the young tree is most astouishing. Leaders (end shoots) of over 24 inches in length on trees 6 to 15 feet high are eommon, and the increase in dianeter is fully in keeping with this lapid upward growth.

In the Carolinas, Georgi:i, and Florida there are springing up multitndes of groves of young Longleaf Pines, and all stages may be seen, from the seelling, resembling mueh more a large bunclı of coarse grass than a pine, aud the sapling with its straight, stiff, fow-limbed bnt nerer bnsh.like form, to the pole size, 40 to 60 feet high and 8 iuehes in diameter, with its small erown and a shaft well cleaned of branehes whether grown in the open or in the midst of a thieket.

Unfortunately, many of these fine young groves fill victins to the miversal bleeding for tur. pentine, followed by fire, which, however, in many loealities is now reeognized by the prudent residents as fast becoming a enrse to the community, uot only by destroying a valuable sonree of revenne, but by alienating people from theil legitimate bnsiness of farming. Trurpentine oreharling is still continued everywhere in the pinery of North Carolina along and west of the Wilmington and Wellon Railroad. Thus fur the very narrow sapwood, promising lunt a small yield and frequently leading to "dry fuces," i. c., a drying up of that portion of the tree, seems to 
have held back the industry from the slowly grown pines of Florida. Some operators, however, claim that the long season more than makes up for this defect. To what extent this is correct remains to be seen. In Louisiana and Texas bleeding is not carried on cven to the extent to which it is commendable. How long trees of this species can withstand blecding and its effects is well illustrated by old trees in Bertie County, N. C., which were blcd fully eighty ycars ago, and much iniured by fire which ate into the box and "face." These trecs are genernlly sound, have good crowns, and show a fair growth for trees of their size and age. Owing to peculiarities of the market, the butt cut of these logs is usually rejected, and therefore left in the woods.

Lnngleaf Pine is still largely cut into timber, i. e., pieces thicker than 4 inches; much is sawn to order, the entire trunk, therefore, being generally ent into one or two lengths in logging. Special sizes, and also boards of great length and odd widths, are manufactured in great quantities for export. The bulk of Longleaf is still cut with circular saws and is not dricd in kilns, though both band saw and dry kiln have been and are used successfully.

Among the diseases to which this tree is subject, the disease of the cones, recently discovered and studied by Dr. W. T. Swingle, deserves attention. The cones are attacked during the first year of their existence, and instead of attaining only about 1 inch in size, they swell up to the size of a second-year cone ( 3 inches and more), and take on a bright orange color. Only cones of this species and of Pinus heterophylla have so far been found affected. 




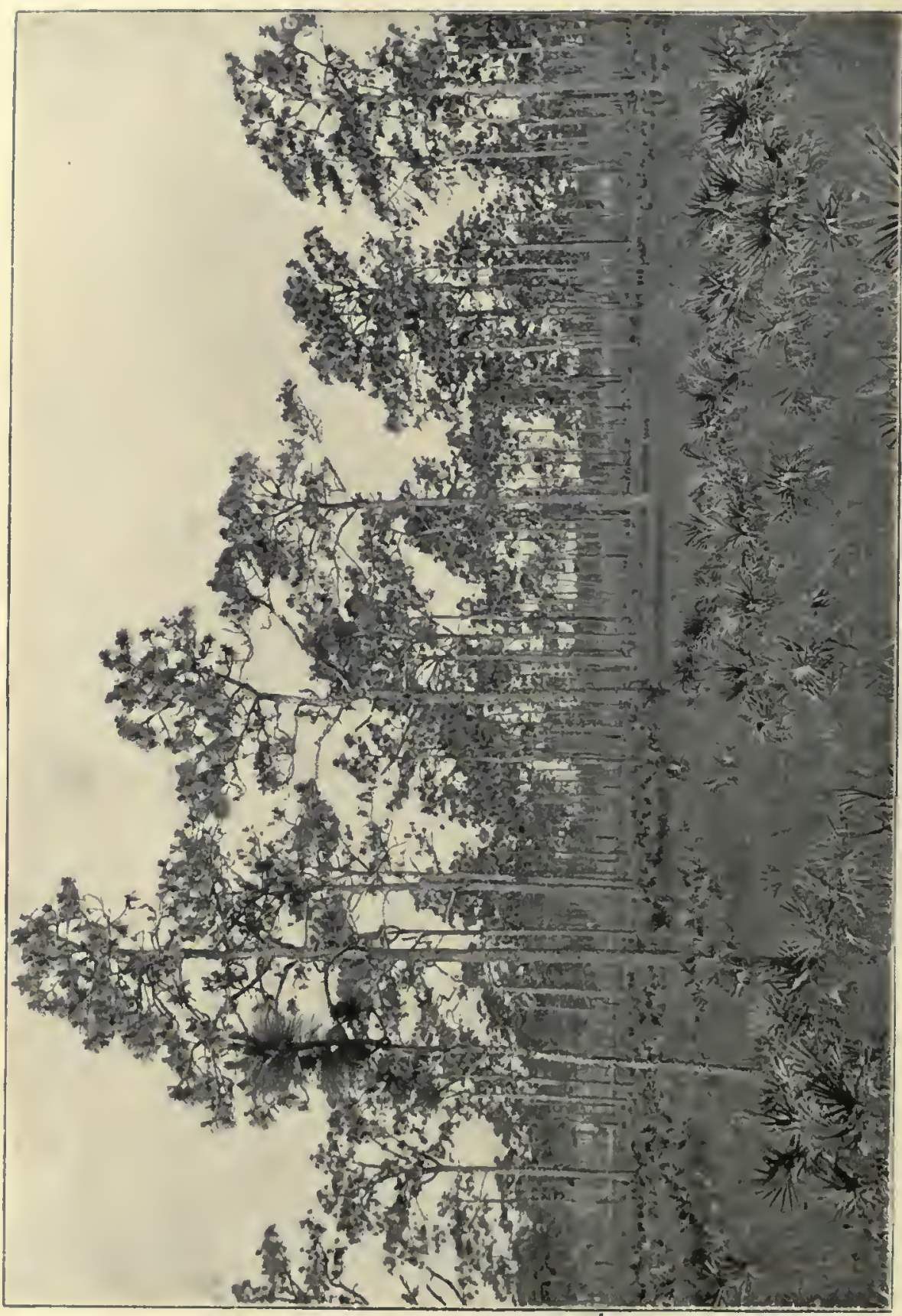




\section{THE CUBAN PINE.}

(PINUS HETEROPHYLLA (ELL.) SUdw.)

Geographical Distrimution.

ProduCT's.

Classification and Nomexclature.

Denchiption and Morphologi al Characters.

PIRGRESS OF DEVELOPMENT.

liequiREMENTS FOR IEEVLOPMENT.

adpitional fotes on Cuiban Pine. 


\section{THE CUBAN PINE.}

(Pinus heterophylla (Ell.) Sudw.)

Syuonyms: Pinns Treda var. heterophylla Elliott, Sk., ii, 636 (1824).

Pinus Cubensis Grisebach, in Mcm. Am. Acad., viii, pt. 2, 530 (1863), not Hort. ex Gord. (1858).

Pinus Cubensis var. terthrocarpa Wright in Grisebach, Cat. Pl. Cuben., 217 (1866).

P'inus Elliottii Engelınann ex Vasey, Cat. Forest Trecs, 30; in lep. Com. Ag. 1875, 178 (1876). Pinns Elliottii Engelmann, in 'Trans. St. Lonis Acad., iv., 186, t. 1, 2, 3 (1879).

Pinus heterophylla (Ell.) Sudworth, in Bull. Torr. Bot. Cl., XX, 45 (1893).

COMMON OR LOCAL NAMES.

Slaslı Pine (Ala., Miss., Ga., Fla.).

Swamp Pine (Fla., Miss., Ala.), in part.

Bastard Pine (Ala. lumbermen, Fla.).

Meadow Pine (Fla., E. Miss.), in part.

78
Pitch Pine (Fla.).

She Pitch Pine (Ga.).

She Pine (Ga. and Fla.).

Spruce Pine (So. Ala.). 


\section{THE CUBAN PINE.}

By Charles Mohr, Ph. D.

\section{INTRODUCTORY.}

Confined within narrow limits along the coast of the extreme Southern States east of the Mississippi River, little known and mostly confounded with its allied species, the valuc of the Cuban Pine has been scarcely recognized. A closer iuvestigation of the propertics of its wood, of its life history, and of the part it plays among the forest growth soon discloses its economic importance. Convinced that to meet proper appreciation the merits possessed by this pine need only to be male more gencrally known, their consideration in this place among the biological iuvestigations of the more important timber trees of the coniferous order will explain itself.

This tree was not known to the earlier American botanists. Elliott first ${ }^{1}$ took notice of it as a clistinct form, and he regarded it as a variety of the Loblolly Pine. It remained still practically unknown as a separate species for another half century, until near the begiuning of the past decade, when it was again brought to the notice of botanists by Dr. Mellichamp, of Bluffton, S. C.; Dr. Engelmann exhibited clearly its specific chararters, and for the first time directed attention to the economic value of this pine by discussing the development of the tree and the qualities of its timber. ${ }^{2}$ On account of the coarser grain of its wood and the large amount of sapwood, this tinber was licld to be of little value, and the tree received little or no attention by the lumbermau. It is only very lately, especially sinec kiln-drying has become more general, that its value is being recognized and appreciated, and under the name of "Slash Pine" it is cut and sold without rliscrimination with the Longleaf Pine, with which it is usually associated.

\section{GEOGRAPHICAL DISTRIBUTION.}

The Cuban Piue is a tree of the coast region in the subtropical region of North Apnerica cast of the Mississippi River, and also of the ueighboring tropies, being found in Honduras and Cuba (sec Pl. III). In the United States the tree is confined to the castern belt of the Austro-riparian or Louisianiau life zone of American biologists, from $33^{\circ}$ north latitude in South Carolina along the coast to the extremity of the peuinsula of Florida. Toward the west the tree extends along the coast of the Gulf to the Pearl River Valley. It is principally restricted to the coast plain, but on the Gulf Coast and along the water courses it extends inland to a distance of fully 60) miles from the sea. On the Atlantic Coast it penetrates the interior nearly to the limit of the coast pine belt, as has been observed in Georgia iu the valley of the Ocruulgee River, over 100 miles distant from tide water. Groves of the Cuban Pine skirt the low shores of the numerous inlets and estuaries of thesc coasts, and cover the outlying islauds. More or less associated with the Loblolly and the Longleaf Pine, it forms a pari of the timber growth of the open pine forests which in unbroken monotony cover the flats for long distances. It is only in the lower part of Florida, where the tree cxtends from the Atlantic across to the Gulf of Mexico, south of Cape Canaveral and Biscayne Bay, that, as the only pine there, the Cuban Pine forms forests by itsclf. Toward the interior it occurs scatteren anong the varied growth of broad-leafed evergreens and conc-bearing trees which cover the swamps along the streams. Since it is invariably cut and sold

\footnotetext{
' Jilliott, Sketches of the Botany of South Carolina and Georgia, Vol. II, page 263, 1821."

"lingelman: Revision of the genns l'inus and description of P'imus elliottii. Transactions St. Louis Acad. Sci., Vol. IV, 186, 1879.
} 
withont distinction, no fignres can be given of its anmul consmuption, nor is it possible to form even an approximato estinate of the standing snpplios. The old timber goes, of eourse, as fast as that of the longleaf Pine, bnt in its reprodnetion it outstrips the latter. Wherever in the eoast plain the original growth of the Longlen f'ine has been remover, the Cuban Pine takes, in a great measure, possession of tho gronud, in some localities associater with tho Loblolly Pine. Young forests in every stage of growth are seen eovering traets of greater or lesser extent, promising important supplies of resinous products, timber, and fuel.

\section{PLODUCTS.}

As a timbor tree the Cuban Pine is little inferior to the Longleaf Pine. It furnishes stieks of large dimensions free from blemish, rivaling in tlat respect that superior variety of the Loblolly Pine called Rosemary Pine, and there is no donlt that it was often confonnded with this tree in the shipments of unsts and long spars made in former years fron the sonthern Atlantic and eastern Gnlf ports. In the lnmber mills on the Atlantie Coast the timber of this tree is indiserininately sawu and shipped with that of the Longleaf Pice.

It remains yet to be proved whether the coarser strncture of tho wood of the Cuban l'ine wonld render it less durable. It is eertain, however, that this very eause, which might interfero with its resistance to atmosplerice influences or to contact with the soil, will be found an advantage if the preservation of the timber is to bo secured by its impregnation with antiseptic solntions, more open strncture permitting ro:adier infiltration.

Resinous products. -This pine abounds in resinons matter. 'The olenresin, resin, or crnde tmrpentine, when freshly exuded, is perfectly limpid, of honey-yellow color, less viseid than the resinous prodnet of the Longleaf Pine, and to all appearanees rielier in volatile oil or spirits of turpentine, judging by the smaller amount of hard gum or sernpe formed on the tree. A sample of the dip of the first year from Sonth Carolina was to all appearance exposed for a short time in the box to atmospherie influences. Examined by Prof. E. Kremers, University of Wisconsin, the resin shower an emmlsion-like appearanee and separated npon standing into lieavier gramles and into a lighter, transparent, yellowish liquid. Its speeifie gravity at $20^{\circ} \mathrm{C}$. was found $1.0253 . \quad 10=3 \pm .4230$ (determined in 16.26 per cent aleoholie solntion). Distilled with water, tho sample yiolded 16 jer eont of oil of the specifie gravity $0.865\left(20^{\circ} \mathrm{C}.\right) . \quad \mathrm{N}=9.620$.

In view of the rapid destruction of the forests of Longleaf Pine, tho prineipal source of resin, the future importanee of the Cuban Pine in the prorhetion of naval stores becomes at once apparent, espeeially when it is considered that it reprodnces itself so mueh more readily. Even now, on the eoast of Sonth Carolina and Georgia, a large proportion of resinons produets is derived from the young growtl of this pine, whieh, after the removal of the original timber growth, took possession of the gronnd. It is claimed by the turpentine gatherers in these States that at an age of from thirty to forty years the trees are sufieiently large for tapping with advantage, and that proteeted against fire a spontaneons renewal takes place, and after a period of forty years the now crop is ready for profitable exploitation.

In Washington Connty, Ala., on the more or less extensive flats that intervene between the low ridges eovered with Longleaf Pine, the Cuban Pine furnishes eonsiderable supplies of ernds turpentine of superior (unality. In this seetion the tree is known nnder the name of Spruce Pine, a misnomer, leading to its eonfusion with an entirely different trce, the true Sonthern Sprnce Pine (Pinus glabru).

\section{CLASSIFICATION AND NOMENCLATURF.}

Pinus heterophylla is elosely allied to the Longleaf Pine, forming with this and two other species inhabiting the nearest tropieal regions-Cnba and Mexico-nucler the snbgenus pinaster, a natural gronp of trees with heavy resinons woor, rigirl long leaves from two to five in a sheatl. and subterninal or lateral, horizontal or reflexed eones, designated by Englemam as the group of the Enanstrales, or longleaf pines. First distinguished by Llliott as Pinus fedu var. heterophyllu and reunining subsequently muknown for unore than fifty years, the speeifie characters of this pine were first recognized and fnlly described by Dr. lìngelmann, who in honor of its discoverer distinguished the tree under the name of Pinus elliottii, finding limself soon atterwards convinced of the identity 
of his speeies with Pinus cubensis of Grisebach. Reeently these various forms were found to be the same as Elliott's, to which they have been referred with his varietal name heterophylla l'aised to specific rauk. The tree is little known anong the inhabitants of the region of its growth; it is generally regarded as a mere variety or bastard form of the. Lougleaf or the Loblolly Pine. In Florida, where best known, it is distinguished as the Slash Pine, or Swamp Pine; and in tle flat wools along the seashore in Alabama and Mississippi as Meadow Pine. In a few localities in Alabana it is erroneonsly called Spruee Pine.

\section{DESCRIPTION AN1) MORPIIOLOGICAL CHARACTERS.}

The leaves, two or three iu a bundle, are surrounded by a smooth sheath from oue-half to nearly an incl iu leugth, which, close aud smooth during the first season, beeome loose and shriveled in the second ycar $(\mathrm{Pl} . \mathrm{X}, \boldsymbol{l})$. The leaves are from 8 to 12, mostly 9 inches in length and three-fourths of a line wide, glossy, of a deep-green color and elosely serrulate with a short, rigil point. rounded on the baek, the binary leaves deeply concave and the ternate bluntly keeled. 'They arise from the axils of fringed decidnous bracts, are densely crowded toward the eud of the branches, and are sherl by the close of the second season. Bundles with two leaves are anost frequently observed in younger trees and almost invariably on the fertile branchlets.

The resiu dnets are internal, variable in size, and in uumber from four to six aud over, close to the thin-walled bundle sheaths, which inclose two closely approximate fibrovascular bundles, often coalesting. The fibrovascular region, like the ducts, shows no hypodermal or strengthening cells. The liypodermal cells underlying the epidermis are as large as the epidermal cells, in the angles of one or several layers.

Flowers.-The eatkin-like male flowers (Pl. X, $a, b)$, from $1 \frac{1}{2}$ to 2 iuches long, are of dark purple (royal purple) color, supported ou a slıort stalk and surrouuded by about a dozen iuvolueral coriaceous bracts, of which the lowest pair is strongly keeled (Pl. X, b, slightly magnified), the others being oblong with fringed edges. From ten to twenty of these cylindrical flowers are erowded in dense clusters below the apex of the youngest shoots, and are shed almost inmediately after the discharge of their abundant pollen. The anthers are erowned with a purplish eleseent-shaped denticulate crest. The female flowers form an oval, pink-colored ament borıe on a stalk, from onehalf to 1 inch in lengtlı, which singly, more frequently several in number, are produced elose to the terminal bul of the shoot of the season (PI. X, $d$ ). "First erect, they are, at the lapse of a montl, liorizontally reflected, the shoot bearing them increasing rajidly in lengtlı during the same time, long before the unfolding of its leaf buds. The involueral seales or bracts which surıonud the female catkin arc more numerous, narrower, louger, and more membranaceous thau those forming the involucre of the male flowers. The curpellary scales are round with a slender, erect tip, their lower half covered by the broad retuse bract.

A trec discovered by Dr. Mrellichamps near Bluffton, S. C., showed the remarkable anomaly of producing androgynous flowers regularly every season. In most of the specimeus examined every one of the male flowers clustering arouud the base of the terminal bud of the very young sloot had the upper part of the floral axis covered with female flowers, appeariug like a distinct inflorescence superimposed upon the staminodial column, oecupying generally one-tlird of its height. In one of the flowers they were seen to extend near to its base. In a single instance it was observed that the female Howers extendec on one side of the staminodial column in a uarrow streak among the stamens.

In a specinen from the sane locality the terminal shoot of the season, exeeding in length the unale flowers by whiel its base was surrounded, was bearing a normal subterminal female anent. 'The sliort-stalked cones are ovate or conical, rather obtuse, horizontally reflexed, from 4 to 5 inches long, about $2 \frac{1}{2}$ inehes greatest width, of glossy leather-brown or hazol color (Pl. XI, $a$ and $b$ ); scales about 2 inches long averaging five-eighths of an inch in width, somcwhat flexible, the prominent ridge of the pyramidal striated nmbo witl a short, mostly straight, strong priekle (Pl. Xr, $c$ and $d$ ). By the end of the first season the eonelets are searcely an ineh long $(P l . X, d)$. Before the close of the summer of the suceeding year, the eones liave reaelied their full size, maturing during the month of Oetober. In the ripe cones, alrealy deseribed, the apophyses of the seales in the lower rows are almost pointless, becoming on the npper strongly mucronate. 'The cones remain on the tree until tho approach of the next summer, leaving on their' separation the lowest rows of the suales belinil.

7092-No. 13_6 


\section{EXPLANATION OF PLATH $x$.}

[Figures natural size, except where otlierwise noted.]

Fig. $a$, branch with young shoot of the season hearing a cluster of male flowers; $b$, male flower detacherl showing basal involucral hracts, magnified three diameters; $c$, lorath hearing three subtcrminal fouale flowers; $d, d$, ehiracteristically reflexed immature concs of one scason's growth. 

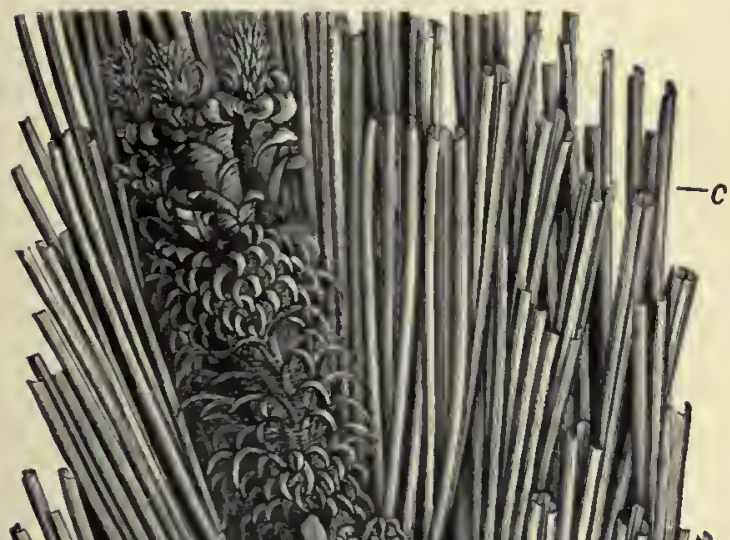

111

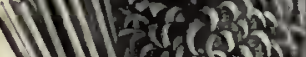

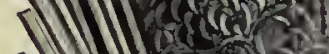

MIV $\frac{1}{2-4}$

A IIV (ca)

1 H 1 -

MININ

NIN1N

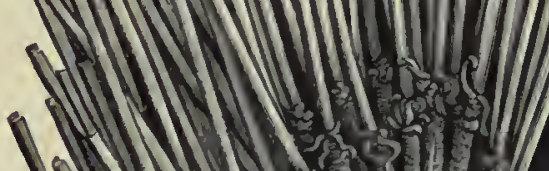
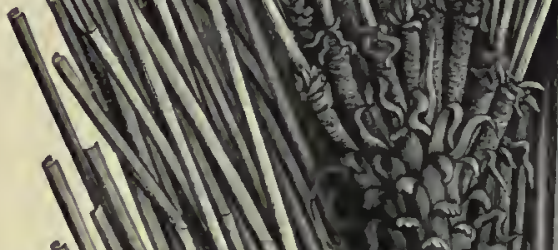

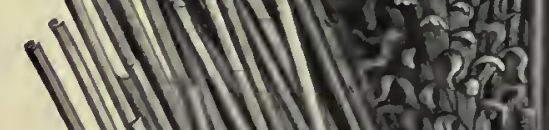

11111111

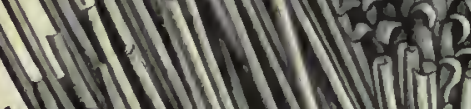

n
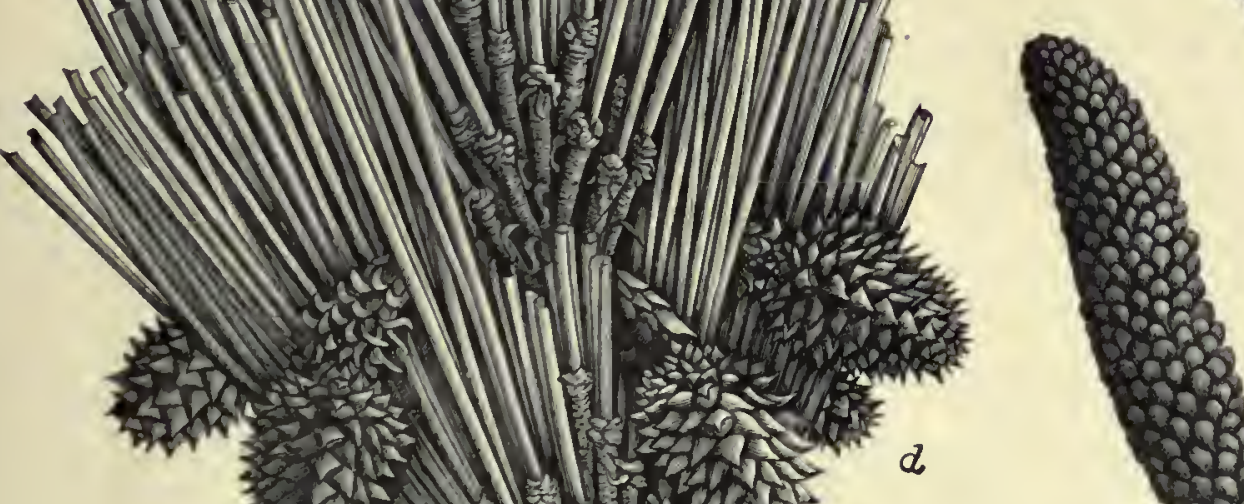

1.
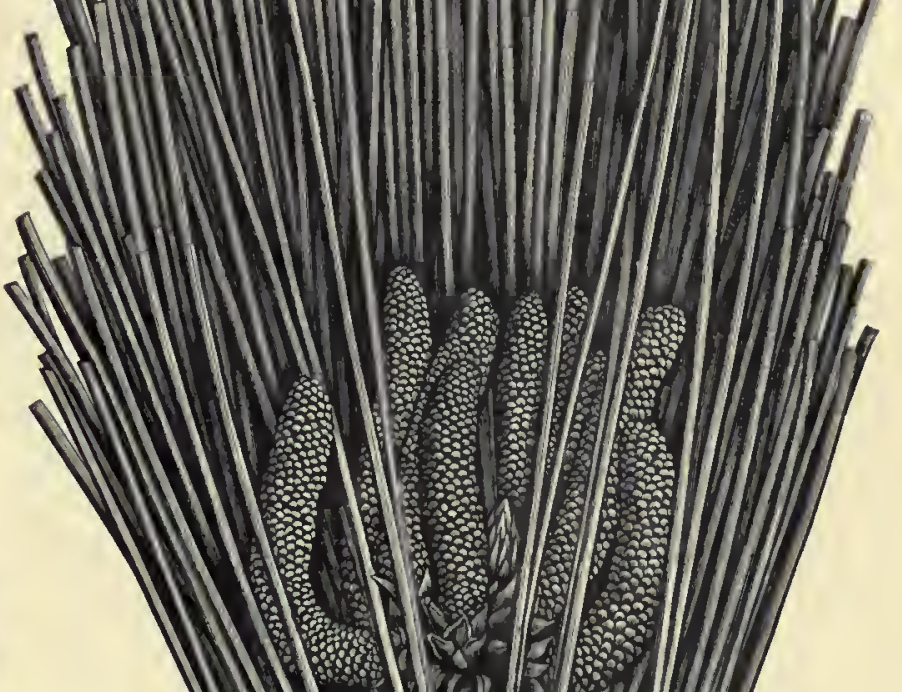

The trimgular black ronghish seeds $2 \frac{1}{2}$ to a little over 3 lines long, with a few faint ridges; the brown, obtuse, and somewhat oblique wing (Pl. XI, $e, f, g$ ) about 1 ineh in length is deeiduons in germination. This species at all stages of growtl ean be distinguished from the Loblolly Pine by the deep-green foliage, the glaueous hue of the young, tender shoots, and varying number of leaves in a bundle-from the Longleaf Pine by the thinner, almost smooth, terminal buds, and in the arlult state, from buth of these speeies, with whieh it is found frequently assoeiated, by its eones.

\section{THE WOOD.}

As in the Loblolly, the sapwood is wide in the young trees, measuring nsually about 4 inehes and forming in thrifty trees fifty to seventy years old about 80 per eent of the total volume. As the trees grow older, however, this preponderance of sapwood eeases, and in trees one hnndred and fifty to two hundred years old only 35 to 50 per eent of the total volume of the trunk was found to be composed of sapwood. As in the ease of the pines already mentioned, the eliange from sap. wood to heartwood begins when the tree (or disk) is about twenty-five to thirty years old, and the process is retarded as the tree (or disk) grows older, so that when any one disk is sixty years old the saprood eontains about forty rings, and reaehes eighty rings or more by the time the tree (or disk) is two liundred years of age. As a consequenee the sapwood of the disks of the main part of the trunk in old trees is formed of nearly the same number of rings, and only near the top a marked diminution appears, while in a tree sixty years old the sapwood of the stump may liave forty rings and that of a disk 40 feet from the ground only twenty-five rings. As in other pines, the width of the sapwood is quite variable and is always greatest in young and thrifty trees.

When green the wood of this speeies is too heavy to float well; its weight varies ehiefly with the anount of sapwood, and is therefore greatest in sapling timber. The sapwood itself is freqnently heavier than water, and where the water in the sapwood and a large amount of resin in the heartwood eombine, the weight of the entire disk frequently approaehes 60 pounds to the enbie foot.

Kiln-dried, the wood of trees one hundred to one hundred and fifty years old was found on an average to weigh about 39 pounds per enbie foot, thus exeelling in weight even the valuable Longleaf Pine. The wood of very young trees is deeidedly lighter, as is also that of very old trees, the heaviest wood being formed during the age of thriftiest growth or between the twentieth and eightieth year. The presenee of resin in the heartwoorl, as eonspieuons in this speeies as in Longleaf Pine, materially adds to the weight of the wood, so that the heartwood of old trees is invariably heavier than the same wood had been while in a sapwood eondition. As in other pines, the butt is heaviest and the top log lightest; thus in trees over one hundred and fifty years of age the wood at the butt weighs 44 pounds per eubie foot, 37 pounds at 38 feet, and only 32 pounds at 60 feet from the stump, a differenee amounting to over 25 per eent. This difference is greatest in the young sapling and is remarkably uniform for all adult trees exanined.

In strength, as in weight, the wood of Cuban Pine exeels. 'The following figures represent the general average of a long series of experiments on wood espeeially eolleeted:

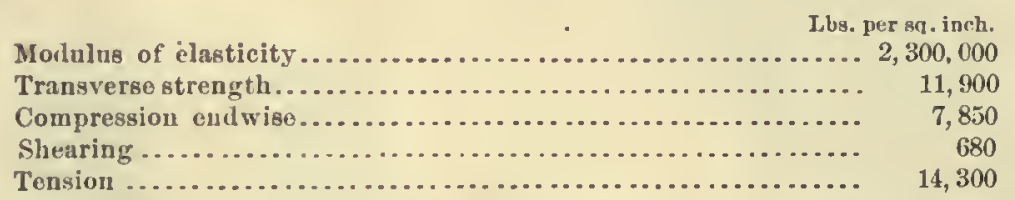

The average weight of the pieces testerl was 49 pounds per eubie foot, the outer lighter part of the old trees having largely been ent away in shaping the piees, so that only heavy wood lad been testerl. The above figures require, therefore, a reduetion of about 20 per eent to represent the true average strength of all the woml of entire trees.

The anount of water eoutained in the freslı wool depends on the proportion of sapwood. In this latter it forms about 60 per eent of the weight of freslı wood; in the heartwoorl only about 20 per cent. Aeeordingly, fresh logs of trees seventy year's old have about 45 per eent, $\operatorname{logs}$ of irees over one hundred and fifty years old only abont 30 per cent of water. The wood dies easili and without great injury, even if seasoned in the dry kih. 


\section{EXPLANATION OF PLATE XI.}

Fig. $a$, section of a branch bearing a mature closed coue (October); $b$, mature open cone after shedding scerl; $c, c, c$, tips of cone seales showing variation in form of apophysis and stout prickle; $d$, cone seale, outer or dorsal side; $e$, inner or ventral side of cone scale with seed in place; $f$, secd with wing detacled; $g$, sced and wing intact. 

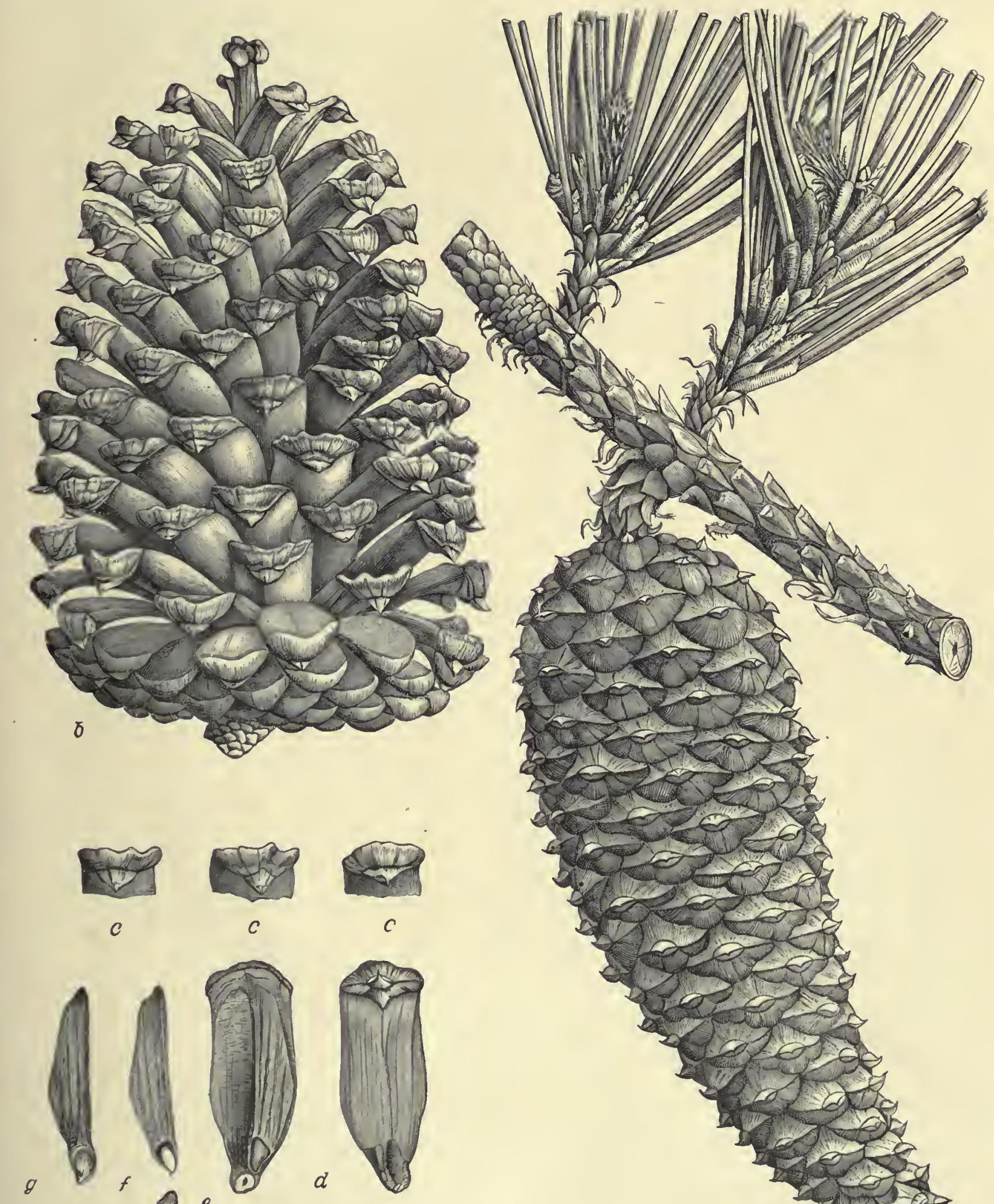

D.CLEIEWSRi dex.

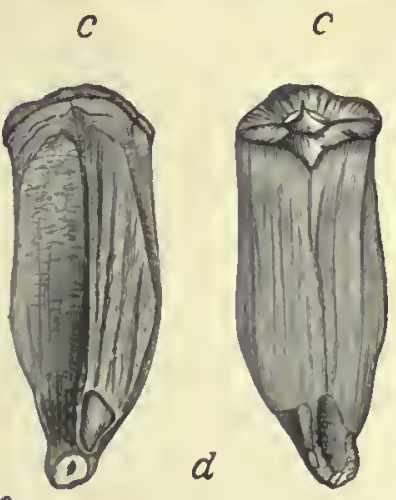

$\theta e$

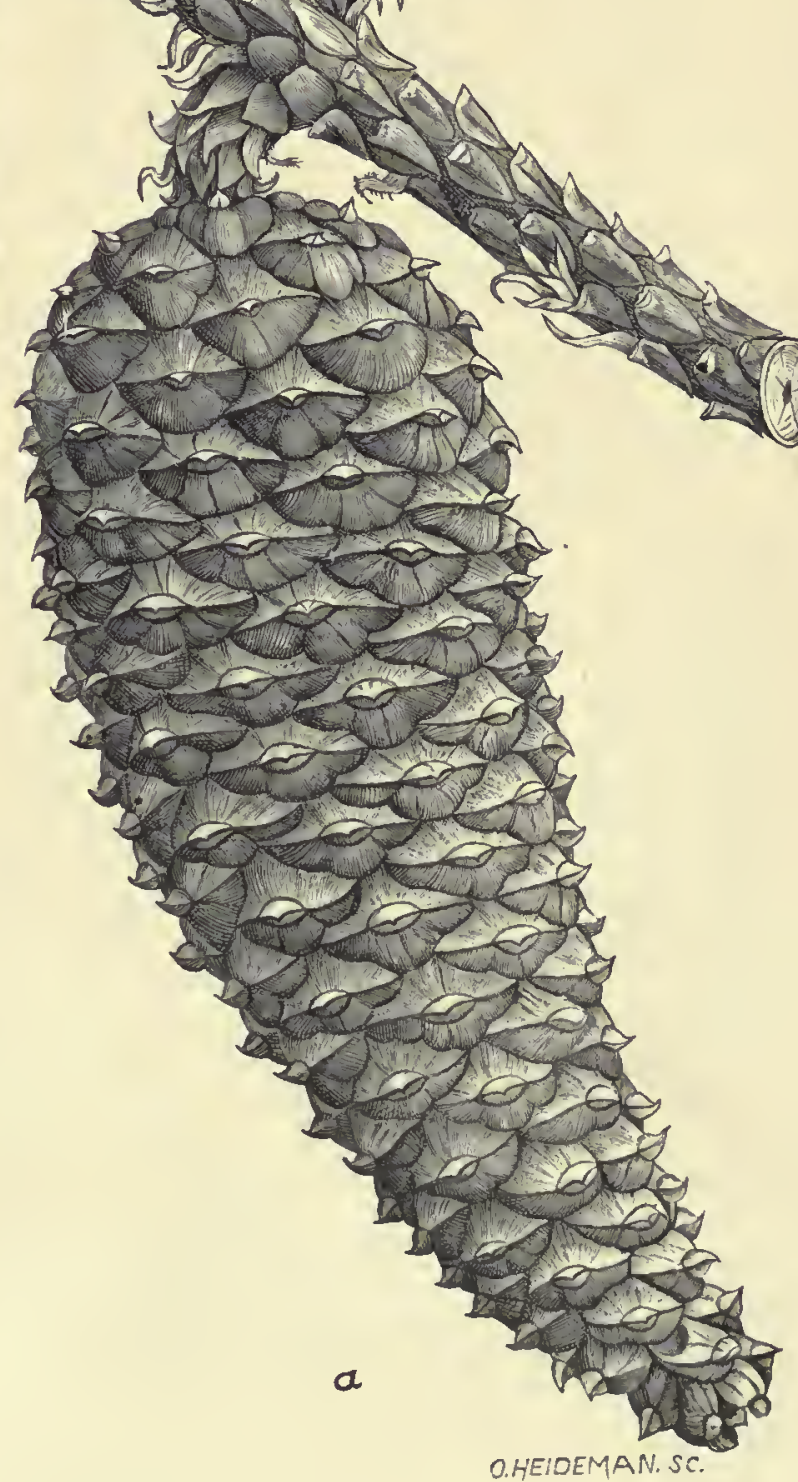

Pinus heterophylla: Cone AND Seed. 

The shrinkage during drying is very eonsiderable for sapwood, and therefore all young timber: but is not as great for old timber as might be expected on account of the great weight of the wood. Young timber shrinks from 12 to 13 per cent of its volume, the wood of old trees (over one hundred and fifty years) only about 11 per cent, and in all trees the amonnt of shrinkage is greatest in the heaviest disk of the butt and decreases npward very mueh in proportion of the decrense in weight.

In its stricture the wood resembles that of the Loblolly in every respect. Sumnerwood and springwood are sharply defined, giving rise to alternating bands of light-colored, soft and dark-colored hard bands of wood conspicuous in every section. For details of structure see the comparative study by Mr. Roth appended to these monographs.

\section{PROGRESS OF DEVELOPMENT.}

This is the earliest flowering of the Southern pines. 'The buds of the male flowers make their appearance in the early part of December, and the flowers open during the last days of January and during the first week of February. This species produces abundant crops of cones every year, almost without failure; they ripen in the fall of the second year; the seeds are discharged through the winter of the second year until spring. Germinating easily, their seedlings are found to come up copiously from early in the spring to the beginning of the summer in old fields and on every opening in the vicinity of the parent trees, wherever the rays of the sun reach the ground. The plantlets bear six to seven seed-leaves (cotyledons). As soon as these have fairly expanded the terminal bud develops rapidly, and the first internode of the stem, increasing quickly in length, is densely covered with the soft, narrow, linear, pointed, primary leaves, which are fully an inch long. Before the end of the second month, in the axils of some of the leaves, the undeveloped branchlets, bcaring the fascicle of the foliage leaves, make their appearance. With the further development of the foliage leaves, increasing in number during the growing season, the primary leaves wither away. By the close of the first scason the plantlets are from 8 to 9 inches high, with a very slender taproot and inany lateral rootlets near its upper end. After the beginning of the second season but few of the primary leaves are found to support the buds of the foliage leaves. The tendency to the production of secondary axes becomes manifest by the appearance of a single branchlet; on having reached the end of their second year the plants are from 12 to 15 inches high, witl a taproot not more than 4 inches long; at the end of their third year they average little less than 2 feet in height, with the taproot 6 inches long-the laterals being much longer. - The crown from this period develops in regular whorls for a long succession of years.

The Cuban Pine, in its rate of growth and when fully grown, equals in its dimensions the Longleaf Pine. The taproot, less powerful than in its allies, is assisted by mighty lateral roots running near the surface of the ground to support the tall, sturdy trunk, rising to a height of 110 or 115 feet, with a diameter of $2 \frac{1}{2}$, not unfrequently exceeding 3 , feet, clear of limbs for a lieight of from 60 to 70 feet above the ground. The heavy limbs are horizontally spreading, from 22 to 24 feet at their greatest length, soinewhat irregularly disposed; they form in the trees of full growth a rather dense crown of rounded outline. Trees of the dimensions mentioned, having passed the fullness of their growth, are found to be from one hundred to one hundred and forty years old, according to the surrounding conditions. The thiek bark is of a clear, reddish color, laninated, and exfoliating in thin, broad, purplish flakes.

Seedlings of the Iongleaf Pine, which those of the Cuban Pine somewhat resemble, can be readily distinguished at this period by the disproportion of height and diameter and absence of branch growth in the former. The rate of growth differs, of course, according to the conditions of soil and exposure.

Saplings showing five rings of annual growth were found from $4 \frac{1}{2}$ to nearly 6 fect in height, with a diameter of from three-fourths to seven-eighths of an inch; between the age of from ten to twelve years the trees measure from 10 to 18 feet in lreight, with the stem clear for over half its length-even when grown in the open-and from 2 up to 4 inches in diameter. From this stage on the rate of growth procceds most rapidly. At eighteen and twenty years heights of 40 to 50 feet and over, and diameters from 9 to 10 inehes across the stump, cut close to the ground, are attained. 
The trees of the extensive groves of Cuban Pine in the vieinity of Mobile npon the loany laids of the eoast plain, which liave sprung up since 1864, when these lands were completely stripped of all arboreal growth, average at present between 50 and 60 feet in height by al cliameter of from 14 to 16 inelies breast high. Trees of second growtl, forming open groves on lands of similar eharacter, and also more or less deficient in drainage, forty-five to sixty-five years old, measure from 65 to 85 feet in height and from 15 to 20 inches in diameter breast high.

At the edge of a heavily wooded swaup, in a perpetually wet, sandy, and mueky soil and skirted by large Longleaf l'ines ocenpying the steep slope rising from the bottom, a tree ineasur. ing 114 feet in height, with a diameter of 24 inelses breast high, the trunk elear of limbs for a length of fully 60 feet, showed one hundred and thirty.five rings of anual growth. Another tree felled deeper in the sane swamp, of lank growtl, with a poorly developed erown, rising to a height of $S S$ feet and towering above the dense growtl of blaek gums, swamp maples, and white bays, was found to measure only $15 \frac{1}{2}$ inches in diameter, with almost the same number of ammal rings. Trees of seeond growtl which have sprung up in elearings with a drier surface soil nuderlaid by a elayey substratum, with free exposure to sunlight and air, reach in little over half the time the full size of those produeed in the forest-eovered swanips.

Taule I.-Growth of Cuban Pine during first stages of life, from four to twenty years.

\begin{tabular}{|c|c|c|c|c|c|c|c|c|}
\hline \multirow{2}{*}{ No. of tree. } & \multirow{2}{*}{ 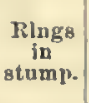 } & \multicolumn{2}{|c|}{ Diameter. } & \multicolumn{3}{|c|}{ Height. } & \multirow[b]{2}{*}{ Loeality. } & \multirow[b]{2}{*}{ lemarks. } \\
\hline & & $\begin{array}{l}\text { Breast } \\
\text { bigh. }\end{array}$ & $\begin{array}{l}\text { Across } \\
\text { stump. }\end{array}$ & Total. & $\begin{array}{l}\text { Tofirst } \\
\text { limb. }\end{array}$ & Crown. & & \\
\hline $\begin{array}{l}1 . . \\
3 . .\end{array}$ & $\frac{4}{5}$ & $\begin{array}{r}\text { Inches. } \\
1 \frac{1}{\frac{1}{3}} \\
1 \frac{1}{6}\end{array}$ & $\begin{array}{l}\text { Inches. } \\
\ldots \ldots \ldots \\
\ldots \ldots \ldots \\
\ldots \ldots \ldots\end{array}$ & $\begin{array}{r}\text { Feet. } \\
3 \frac{1}{3} \\
4 \frac{1}{2} \\
6 \frac{1}{4}\end{array}$ & \begin{tabular}{c}
\multicolumn{2}{c}{ Feet. } \\
$\cdots \ldots \ldots$ \\
$\cdots \ldots \ldots$ \\
$\cdots \ldots$
\end{tabular} & Feet. & & $\begin{array}{l}\text { Nos. I to } 5 \text {, vear Whistler, Ala. } \\
\text { Wet, sand, fiat soil very poor; open thickets in } \\
\text { the clearing of the forest. }\end{array}$ \\
\hline n......... & $\begin{array}{l}6 \\
8\end{array}$ & $\begin{array}{l}1 \frac{1}{2} \\
1 \frac{1}{6}\end{array}$ & & $8 \frac{1}{85}$ & & & & \\
\hline $236 \ldots \ldots \ldots \ldots \ldots$ & $\begin{array}{l}9 \\
9\end{array}$ & $\begin{array}{l}2 \\
2\end{array}$ & 21 & 17 & $\begin{array}{l}10 \\
10\end{array}$ & $\begin{array}{l}7 \\
9\end{array}$ & $\begin{array}{l}\text { W bistler, Ala ...... } \\
\text { Ridgeland, S. C..... }\end{array}$ & $\begin{array}{l}\text { Exposure yartially free; suppressed soll; slushy. } \\
\text { Old flell; Boil fresh; from unidst of dense grove. }\end{array}$ \\
\hline (n........ & 9 & & & 18 & 8 & 10 & 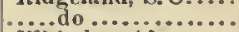 & \\
\hline (......... & 10 & 2 & $\because$ & 18 & 7 & 11 & Whistler, Ala ...... & Open elge of swamp, somewhat suppressed. \\
\hline$\cdots \cdots \cdots$ & 11 & 4 & 413 & 28 & 14 & 14 & Ridgela & $\begin{array}{l}\text { Partially free; edge of swamp. } \\
\text { Open grove of saplings; soil fresh; old fleld. }\end{array}$ \\
\hline $6 \ldots$ & 12 & 3 s & & 19 & & & Mobile, Ala & $\begin{array}{l}\text { Grove of young trees; crown coverud partially loy } \\
\text { large pines; soil conditions, best. }\end{array}$ \\
\hline $291 \ldots \ldots \ldots \ldots \ldots$ & 13 & 6 & & $\begin{array}{l}29 \\
27\end{array}$ & 13 & 16 & Ridgeland, s. C.... & \\
\hline & $\begin{array}{l}14 \\
15\end{array}$ & $8 \frac{4}{2}$ & 1/3 & $\begin{array}{l}27 \\
37\end{array}$ & & & Mobile, A & $\begin{array}{l}\text { Milingt of dense thicket; in the sliade; suppressed? } \\
\text { soil conditiuns, hest. }\end{array}$ \\
\hline $8, \ldots \ldots \ldots \ldots \ldots$ & $\begin{array}{l}15 \\
16\end{array}$ & $\begin{array}{l}9 \\
6\end{array}$ & 7 & $\begin{array}{l}31 \\
36\end{array}$ & 18 & 26 & Kidgela & $\begin{array}{l}\text { Do. } \\
\text { Exposure free; old field; soil black, unuck }\end{array}$ \\
\hline $9 \ldots \ldots \ldots \ldots \ldots$ & 16 & 8 & ..... & 46 & 27 & 19 & Mobile, Ala........ & In the shade of large pines. \\
\hline $10 \ldots \ldots \ldots \ldots \ldots$ & 17 & 84 & ;...... & 46 & & $\because \cdots$ & $\cdots$ & Do. \\
\hline $\begin{array}{l}232 \ldots \ldots \ldots \ldots \ldots \\
231 \ldots \ldots \ldots \ldots \ldots \ldots\end{array}$ & 17 & 6 & $6 \frac{1}{3}$ & 38 & 15 & 13 & Ridgeland, S.C..... & Swamp soil; slushy; suppressed. \\
\hline $11 \ldots . .$. & 18 & 8 & 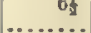 & 40 & 20 & & 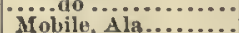 & Exposure free: 801 freab, good. \\
\hline $12 .$. & 18 & 9 & $\ldots \ldots$ & 37 & 14 & 23 & .....do ...... & Do. \\
\hline $13 \ldots .$. & 21 & $10 \frac{1}{2}$ & $\ldots \ldots \ldots$ & 53 & 27 & 26 & .....do. & Freo exposure. \\
\hline
\end{tabular}


TABLE II.-Gronoth of Cuban Pine during middle and last stages of life, from forty to one hundred and forty-five years.

\begin{tabular}{|c|c|c|c|c|c|c|c|c|c|c|}
\hline \multirow[b]{2}{*}{ No. of tree. } & \multirow[b]{2}{*}{$\begin{array}{l}\text { Rings } \\
\text { iu } \\
\text { stump. }\end{array}$} & \multicolumn{4}{|c|}{ Diameter. } & \multicolumn{3}{|c|}{ Height. } & \multirow[b]{2}{*}{ Locality. } & \multirow[b]{2}{*}{ Renarks. } \\
\hline & & $\begin{array}{l}\text { Breast } \\
\text { high. }\end{array}$ & $\begin{array}{l}\text { Across } \\
\text { stump. }\end{array}$ & $\begin{array}{l}\text { Below } \\
\text { crown. }\end{array}$ & Mean. & $\begin{array}{r}\text { Total } \\
\text { height. }\end{array}$ & $\begin{array}{l}\text { Length } \\
\text { to } \\
\text { crown, } \\
\text { clear. }\end{array}$ & $\begin{array}{l}\text { Length } \\
\text { of } \\
\text { crown. }\end{array}$ & & \\
\hline $1 . .$. & 40 & $\begin{array}{r}\text { Inches. } \\
14 \frac{1}{2}\end{array}$ & Inches. & Inches. & Inches. & $\begin{array}{r}\text { Feet. } \\
60\end{array}$ & $\begin{array}{r}\text { Feet. } \\
39\end{array}$ & $\begin{array}{r}\text { Feet. } \\
24\end{array}$ & Mobile, A la....... & Midst of grove, crowded; \\
\hline 290. & 43 & 12 & & & & 66 & 34 & 32 & Rilgeland, S. C & $\begin{array}{l}\text { loam; clay subsoil; surface flat. } \\
\text { Expostire free; edge of swamp; soil per- }\end{array}$ \\
\hline 230 . & 51 & 121 & & & & 87 & 51 & & Whistler, Ala. & Edge swamp; soil fresh to damp; growtl \\
\hline $2 \ldots$ & $\begin{array}{l}52 \\
55\end{array}$ & $\begin{array}{l}17 \\
19\end{array}$ & $17\}$ & & & $\begin{array}{l}83 \\
74\end{array}$ & $\begin{array}{l}50 \\
40\end{array}$ & 36 & $\begin{array}{l}\text { Mohlle, A la } \\
\text { Stockton, Baldwin }\end{array}$ & $\begin{array}{l}\text { lank; sap, } 5 \text { inches. } \\
\text { Edge of grove. } \\
\text { Exposure free; springy hillside; soil }\end{array}$ \\
\hline $5 \ldots \ldots \ldots \ldots$ & 55 & 20 & $\frac{25}{24}$ & $\begin{array}{l}13 \frac{1}{2} \\
19\end{array}$ & & 82 & 50 & $\begin{array}{l}32 \\
32\end{array}$ & 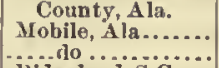 & $\begin{array}{l}\text { coarse, sandy, and gravelly. } \\
\text { Exposure free; open grove. } \\
\text { Do. }\end{array}$ \\
\hline $\begin{array}{ll}289 . . \\
288 .\end{array}$ & 60 & 16 & & & & 90 & 59 & 31 & Ridgeland, S.C... & $\begin{array}{l}\text { Low pine flat, open; soil moist and black, } \\
\text { sour. }\end{array}$ \\
\hline $\begin{array}{l}288 . . \\
6 . .\end{array}$ & $\begin{array}{l}70 \\
87\end{array}$ & $\begin{array}{l}21 \\
20\end{array}$ & & & & $\begin{array}{l}83 \\
85\end{array}$ & 41 & 42 & ..... do ...... & $\begin{array}{l}\text { Exposure frce; soil moist and black, sour. } \\
\text { Spriuglinl ed ge of swamp; damp, sandy. }\end{array}$ \\
\hline 6 & 101 & 24 & & & & 98 & 48 & $\ddot{50}$ & Ridgeland, S.C.... & Exposnre froe; near border of swamp; \\
\hline 227. & 110 & 22 & & & & 90 & 60 & 30 & & $\begin{array}{l}\text { Springlill ricli hummock, perpetually } \\
\text { damp; nagnolia, red lay, spruco, gum; } \\
\text { Consns. } 1880 \text {. }\end{array}$ \\
\hline 227. & 110 & 20 & & & & 113 & 71 & 42 & Whistler, Ala.. & $\begin{array}{l}\text { Exposure free; edge of swamp; soil fresh; } \\
\text { stick perfectly clear for } 52 \text { feet; sal, } 2 \frac{t}{2} \\
\text { inches. }\end{array}$ \\
\hline $225 \ldots \ldots \ldots .$. & $\begin{array}{l}126 \\
133\end{array}$ & 26 & & & & 130 & 78 & 52 & $\ldots . .8$ & Timber perfect for 60 feet. \\
\hline & 133 & 20 & 25 & $14 \frac{1}{3}$ & $21 \frac{1}{2}$ & 118 & 60 & 58 & ..... do & $\begin{array}{l}\text { Exposure free; somewhat suppressed lyy } \\
\text { longleaf pine; edge of swamp. }\end{array}$ \\
\hline & 127 & 20 & & & & 104 & 80 & 24 & ...do & $\begin{array}{l}\text { Exposure freo; lank, tall; red heart above } \\
54 \text { feet. }\end{array}$ \\
\hline 228. & 132 & 22 & & & & 119 & 73 & & .....do & $\begin{array}{l}\text { Base of hili; a fino-looking treo; timber } \\
\text { clear for } 50 \text { feet. }\end{array}$ \\
\hline 229. & 145 & 26 & & & & 116 & 73 & & .....do & $\begin{array}{l}\text { Swamp always slushy; free from knots } \\
\text { for over } 65 \text { feet. }\end{array}$ \\
\hline $9 . .$. & 145 & $12 \frac{1}{4}$ & & 71 & & 67 & 21 & & ... do & $\begin{array}{l}\text { Of suppressed growth; in middle of } \\
\text { swainp; soil pure sand, mostly covered } \\
\text { with water. }\end{array}$ \\
\hline
\end{tabular}

From Table III the rapid growth of this species is quite apparent. It will be observed that good trees are about 20 feet high at ten, 45 feet at twenty, and over 80 feet high at fifty years of age, when the rapill rate of 11 ward growth comes to a stop. It appears, also, that the greatest mass of wood for aly deeade is formed at the early age of fifty, the growth in volume being nearly 15 cubie feet for these ten years, and that at ninety the growth in volume is only about two-thirls of the maximum; that at one hundred years the average annual growtl nearly equals the current growth, thus indieating that the age of proper exploitation has been reaehed, i. e., that now the tree is ripe for the ax, as far as profitable growth, represented in volume aecretion, is concerned.

TAlsL: III.-Growth of Cuban Pine.

\begin{tabular}{|c|c|c|c|c|c|c|c|c|c|c|c|c|}
\hline \multirow[b]{2}{*}{ Age. } & \multirow[b]{2}{*}{$\begin{array}{l}\text { Diameter } \\
\text { with bark } \\
\text { (breast } \\
\text { higli). }\end{array}$} & \multirow{2}{*}{$\begin{array}{c}\text { Length } \\
\text { of log } \\
\text { with } \\
\text { upper } \\
\text { dlameter } \\
\text { of } 5 \\
\text { inches. }\end{array}$} & \multirow[b]{2}{*}{$\begin{array}{l}\text { Height } \\
\text { of tree. }\end{array}$} & \multicolumn{2}{|c|}{ Volnme. } & \multicolumn{5}{|c|}{ Periodical growth for each dccade. } & \multirow[b]{2}{*}{$\begin{array}{l}\text { Arerage } \\
\text { annual } \\
\text { accretion. }\end{array}$} & \multirow[b]{2}{*}{$\begin{array}{c}\text { Current } \\
\text { accretiols. }\end{array}$} \\
\hline & & & & Tree. & $\begin{array}{l}\text { Log np to } \\
5 \text { inches } \\
\text { diameter. }\end{array}$ & Decade. & $\begin{array}{l}\text { Diam- } \\
\text { eter. }\end{array}$ & Height. & $\begin{array}{l}\text { Area of } \\
\text { eross } \\
\text { section. }\end{array}$ & Volume. & & \\
\hline & Inches. & Feet. & Feet. & Cubic feet. & Cubic feet. & ir & Inches. & Feet. & Sq. feet. & Cubie feet. & Oub. feet. & Cub. feet. \\
\hline 20. & 5.9 & $\ddot{5}$ & 45 & 4.24 & 2.44 & Second. & 2.6 & $\begin{array}{l}20 \\
25\end{array}$ & $\begin{array}{r}0.02 \\
.10\end{array}$ & $\begin{array}{l}0.50 \\
3.74\end{array}$ & $\begin{array}{r}0.05 \\
.21\end{array}$ & $\begin{array}{r}0.05 \\
.37\end{array}$ \\
\hline .. & 9.3 & 24 & 66 & 14.95 & 13.06 & . $\ldots \ldots \ldots \ldots$, & 3.0 & 21 & .2 & 10.71 & .50 & 1.07 \\
\hline .. & 12.3 & 40 & 75 & 29.70 & 29. & 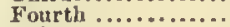 & 2. & 9 & .2 & 14.75 & .74 & 1.47 \\
\hline 50. & 14.8 & 50 & 83 & 47.01 & 45. & Finth $\ldots . . \ldots \ldots \ldots$ & 2.5 & 8 & .2 & 17. & .94 & 1.73 \\
\hline 0. & 16.0 & 60 & 89 & 59.65 & 58. & 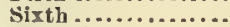 & 1. & 6 &. & 12. & .99 & \\
\hline & 17. & 69 & 93 & 72.25 & 71. & Seventli ............ & 1. & 4 & .1 & 12. & 1.03 & 1. \\
\hline 0 & 18. & 76 & 96 & 84.05 & 83. & Eighth...$\ldots \ldots \ldots$ & 1. & 3 & 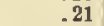 & 11. & 1.05 & 1. \\
\hline 90. & 20.0 & 83 & 99 & 95.03 & 94. & Nlutli............ & 1. & 3 & .2 & 10.08 & 1.05 & 1.10 \\
\hline 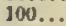 & 21. & 90 & 101 & 105.97 & 105. & Tenth .............. & 1. & 2 & .2 & 10.94 & 1.06 & 1. 08 \\
\hline 110. & 22. & 96 & 103 & 115.58 & 115.27 & Eleventh ............. & 1.0 & $\overline{2}$ & .2 & 9.61 & 1.05 & .96 \\
\hline 120 & 23.4 & 190 & 105 & 125.18 & 124.96 & Twelfth...$\ldots \ldots$. & 1.0 & 2 & .25 & 0.60 & 1.04 & .96 \\
\hline
\end{tabular}




\section{IREQURFMENTS FOR DEVELOPMLNT.}

Soil.-For its best development the Cuban P'ine requires a light, sandy; but constantly damp soil, whiel is attained where the sandy surface is underlaid by a louny subsoil retentive of moisture but sufficiently loose to give the roots unlindered aeecss. Such conditions are found on the lands rising above the perpetually wet swamps. On the flats, with a soil of finc, eompact sand, devoid of all drainage and underlaid by a liarlpan, where nothing but the Saw Palmetto appcars to thrive, the trce remains of low, stunted growth, scarcely ever reaching melinm sizc. In the depth of the swamp, with the soil wet and shishy throughout the year, where the tree is eommonly met witl, closcly surrounded by White Bay, Red Bay, Black Gmm, Titi, and White Cedar towering lighl above it, it is of slow growth and frequently affceted lyy red heart or red rot, partienlarly near its northern limit. It is never fonnd in alluvial bottons, and eschews tlic dry, pine-barren hills, requiring a noderate but sure and even supply of soil moisture.

Climate.-The range of its distribution coincides with the arca of greatest rainfall in the Southern States, which, evenly distributed through all seasons, anounts for the year, in the mean, to 60 and 64 inches.

The Cubau Pine demands a warm climate, free from excesses in the range of temperature, as is aftorded by the vicinity of the sea. It is found in greatest abundance and most perfect within the isothernal lines of $64^{\circ}$ and $68^{\circ} \mathrm{F}$., with a mininum of but a few degrees below the fieczing point. The tree, as obscrved at Mobile, las escaped uninjured the screre and inprecedented long spcll of ice and snow during the latter part of January and first weck of February, 159:, when the thernometer fell as low as $11^{\circ} \mathrm{F}$., the flowers unfolding mimpaired by frost during the suceeeding first days of milder weather.

In its dependence on light it is lcss exaeting than either the Longleaf I'ine or the loblolly Pinc. It appears to thrive, from the earliest stage of its devciopment, as well when partially shaded as in the open, in this respect resembling the Southern Sprnce Pinc. It is duc to thesc facts, combined with the rapid progress of its growth from the earliest stage, that the Cuban Pine is gaining the upper hand over the offspring of the light-requiring Longleaf Pinc, which, on the damp soil of the eoast plain, is sonn outstripped and finally almost eompletely suppresscel by the seedlings of this tree.

In the inherent capaeity for natural reproduction, or in the advantages for the rencwal of its forests by man, the Cuban Pine is not surpassed by any other of the spceics with wlich it is found associated. This tree commends itself strongly to the tree planter in the eonst plain of the lower Sontl. Producing secds in abundance regularly and with ecrtainty, bcing less exacting in its demands for direct sunlight, and hence suceessfully resisting the eneroaehment of eompeting species, being less liable to succumb to the destruetive ageneies of fire on account of its inore rapid development in early life, it has greater promise of suecess than the others. If to this is added the rapid rate of growth, the great valıe of its timber, being equal to the Longleaf, if not superior, and the abnndant yield of its valuable resinous prodnct, it becomes evident that in the reforestation of the low pine lands of the Southern coast region the Cuban Pine is to be preferred to any other, not only within its original boundaries, but as far beyond its range of natural distribution as the climatic requirements of the treo will permit. 


\section{ADDITIONAL NOTES ON CUBAN PINE.}

By lillibert Roti.

(September 1, 1897.)

This tree, like the Longleaf, seems very generally known among woodmen wherever it oecurs in abnndance, and it is usually designated as "Slash Pine." Like Pond Pine, the Cuban l'ine oceurs mixed with other pines, but never seems to form large forests by itself in the districts visited. Along streans and swamps, and also along the occan shore, it nsually forms a fringe varying from a few to several hnndred yards in width. In sonthem South Carolina and Georgia this tree disputes territory with the Loblolly, but in Florida it is found either with Pond l'ine or alone covering the wet flats. More than any other pine the Cuban Pine enters the real wet swamps, being fonnd in eypress ponds and even in the wettest portions of the eonstantly watercovered Okefinokee Swamp. Iike the Pond Pine, it is not found in rieh bottoms and hanmocks. Along the coast of Georgia and the eastern half of Flowida the Cuban Pine forms abont 15 per cent of all pine; it is also quite abundant in the low flat woods between the Suwane and the A jalaehicola, where it forms about the same proportion; but in all other parts of the Gulf pinery where it oceurs the tree is too scattering to be of any great eonsequenee.

The size of the Cuban Pine denends on loeality or station, and while practically as well dcveloped in Soutl Carolina as in Alabama it is very much inferior in the barren flats of a large part of Florida. Here this tree, like the Longleaf of this section, is short-bodied, 50 to 70 feet ligh, and furnishes a $\log 25$ to 40 feet in length. But, like Longlcaf, Cuban Pine in these loealities is of a very superior quality, fine ringed, with little sap, of uniform weight and strength, and unch of this timber eould not be distinguished by the best of experts from high-grade Longleaf timber. This faet is well recognized, and Cuban Pine is logged with Longleaf without distinetion. In manner and rate of growth the Cuban Pine of sonthern Georgia and of Florida resembles Longleaf in several respects. Its growth while young is cxtremely rapid both in height and thiekness, leaders of 24 to 30 inches bcing not uncommon. Like the Ionglcaf, thongh to a less extent, this tree eleans itself even without erowding, and makes fine, clcan-shafted, short-erowned poles in very open stands. This is much more the ease on very poor soils or loealities where the tree never reaelies large dimensious. 




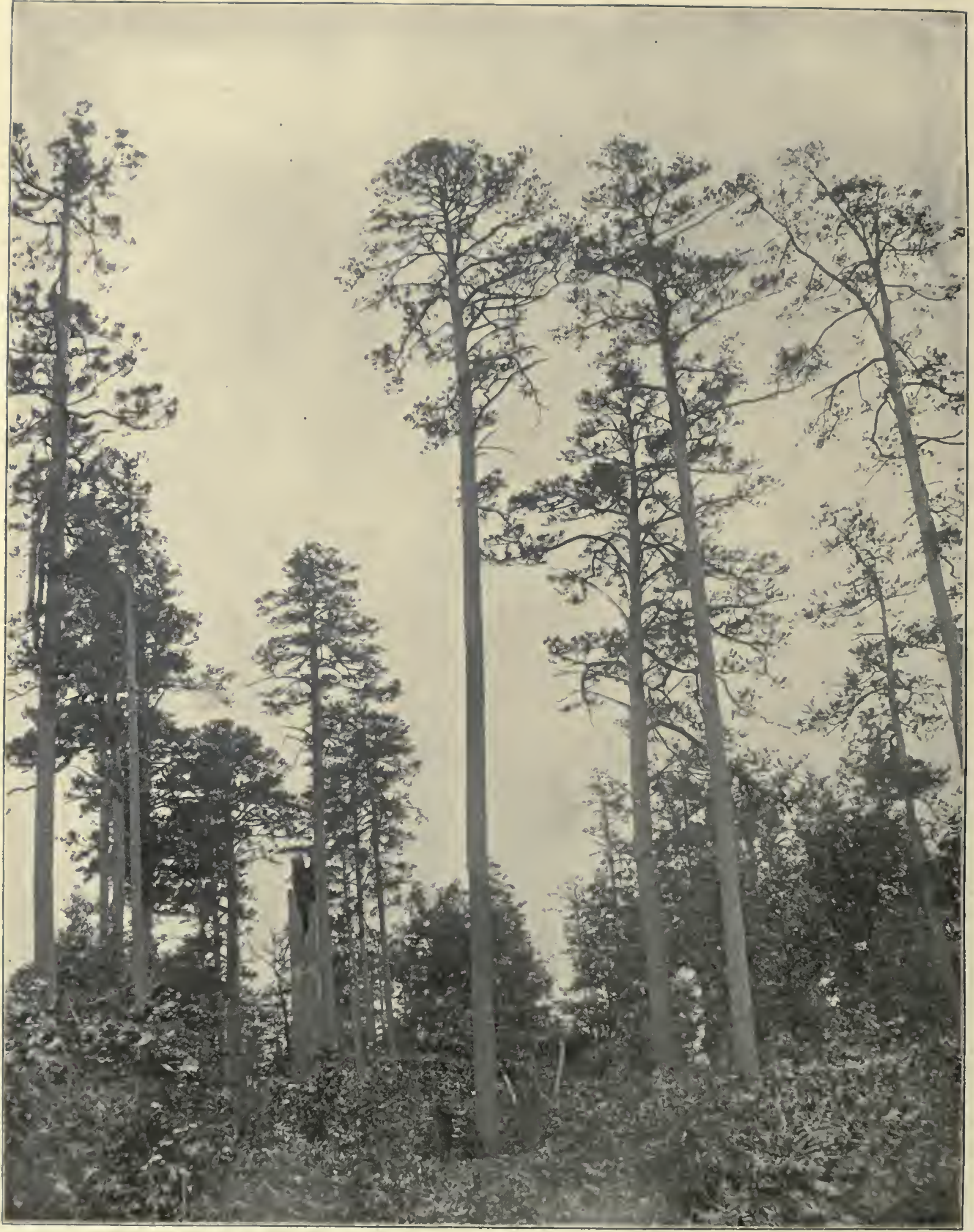




\section{THE SHORTLEAF PINE.}

(PINUS ECHINATA Miller.)

Economic History and Distribution.

Botanical DEscription.

Description of Wood.

Progress of Development.

CONDITIONS OF DEVELOPMENT.

Forest MaNagenert.

additional Notes on Silor'tleaf Pine. 


\title{
THE SHORTLFAF PINE.
}

\author{
(Pinns pelinata sliller.) \\ Synongus: Pinns relinata Miller, Gard. Dict., ed. 8, No. 12 (1768). \\ P'inns Virginiana var. echinata Du Roi, Harbk., ii, 38 (1772). \\ J'inus Terda y rariabilis Aiton, Hort. Kew., ed. 1, iii, 368 (1789). \\ Pinus milis Michanx, l'l. Bor. Am., ii, 204 (1803). \\ Pinns caviabilis launbert, Pinus, ed. 1, i, 22, t. 15 (1803). \\ I'inus Royleana Jauieson ex Liudley, in Jouru. Hort. Soe., ix, 52 (1855). \\ Pinus infermedia Fischer ex Gordon, Pinetum, ed. 1, 170 (1858), not Du Roi (1772). \\ Pinns rigida Porcher, Resonrces S. States, 501 (1863), not Miller (1768). \\ Pinns Intea Loddiges ex Gordon, linetum, ed. 1, 170 (1858), not Walter (1788). \\ Pinus Roylei Lindley ex Gord., l. c. (1858).
}

\section{COMMON OR LOC'AL NAMES.}

Fellow Pine (N. Y., X. J., Pa., Del., Vil., X. C., Aliı., Miss., La., Ark., Mo., Ill., Ind., Kans. (scilco), Olio).

Shortleaverl P'ine (N. C., S. C., Gia., Ala., Miss., Flaı, Liı, Tex., Ark.).

Spruce Pine (Del., Miss, Ark.).

liull line (Va.).

Short Schat Pine (Del.).

Pitch Piu. (Mo.).

Poor l'ille (1"lu.).

92
Slortleived Yellow Pine.

Yellow Pino (N. C., Va.; Eng. lit.).

Virgiuin Yellow Pine (Va., in part).

North Caroliua Yellow Pine (N. C., Va., in pirt).

Nortl Caroliua Pine (N. C., Va., ill part).

Caroliua Piue (N. C., Va.. in part).

Slash Pine (N. C., Vil., in part't).

Oldtield Pinc (Alit., Miss.). 


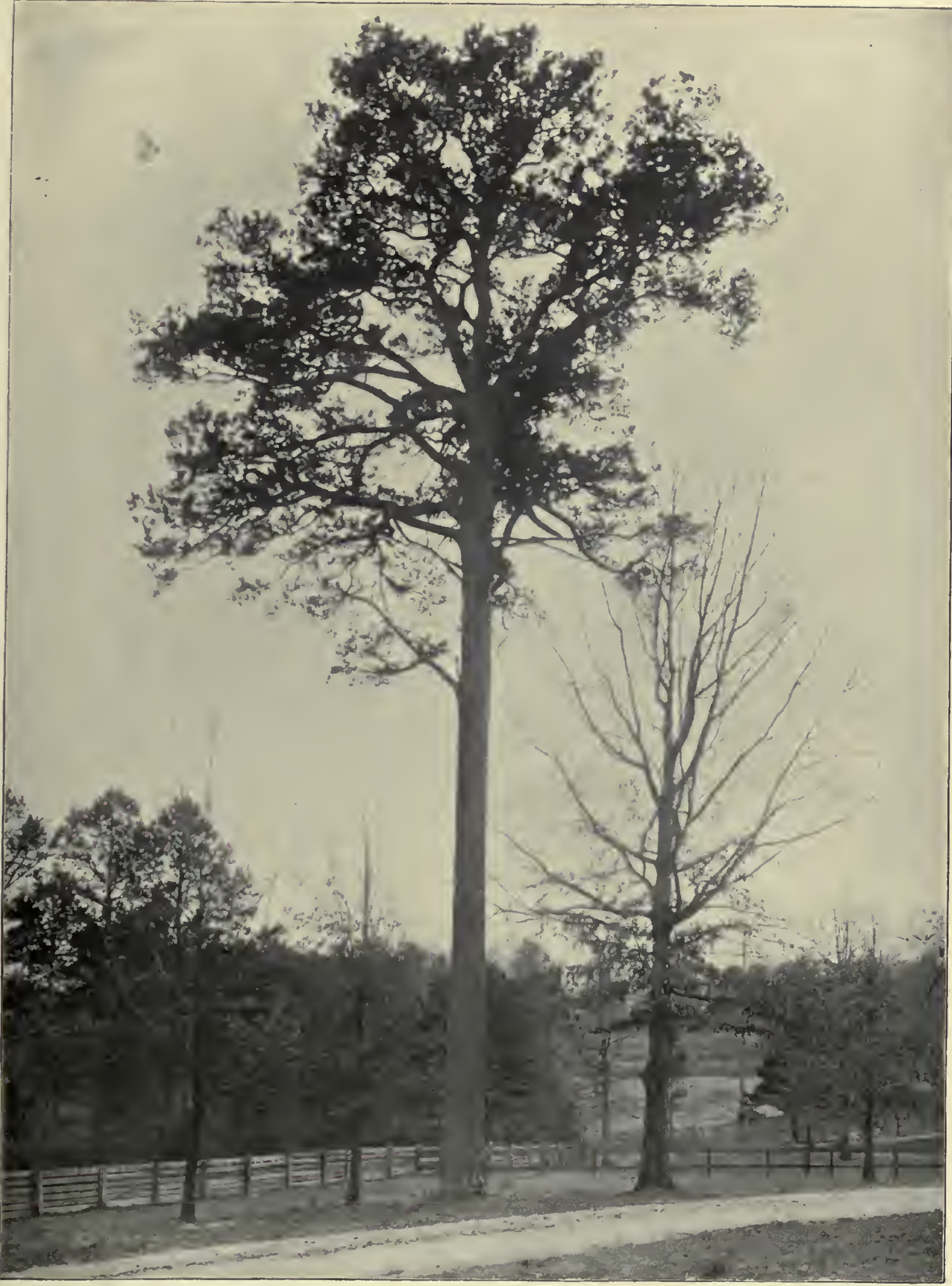




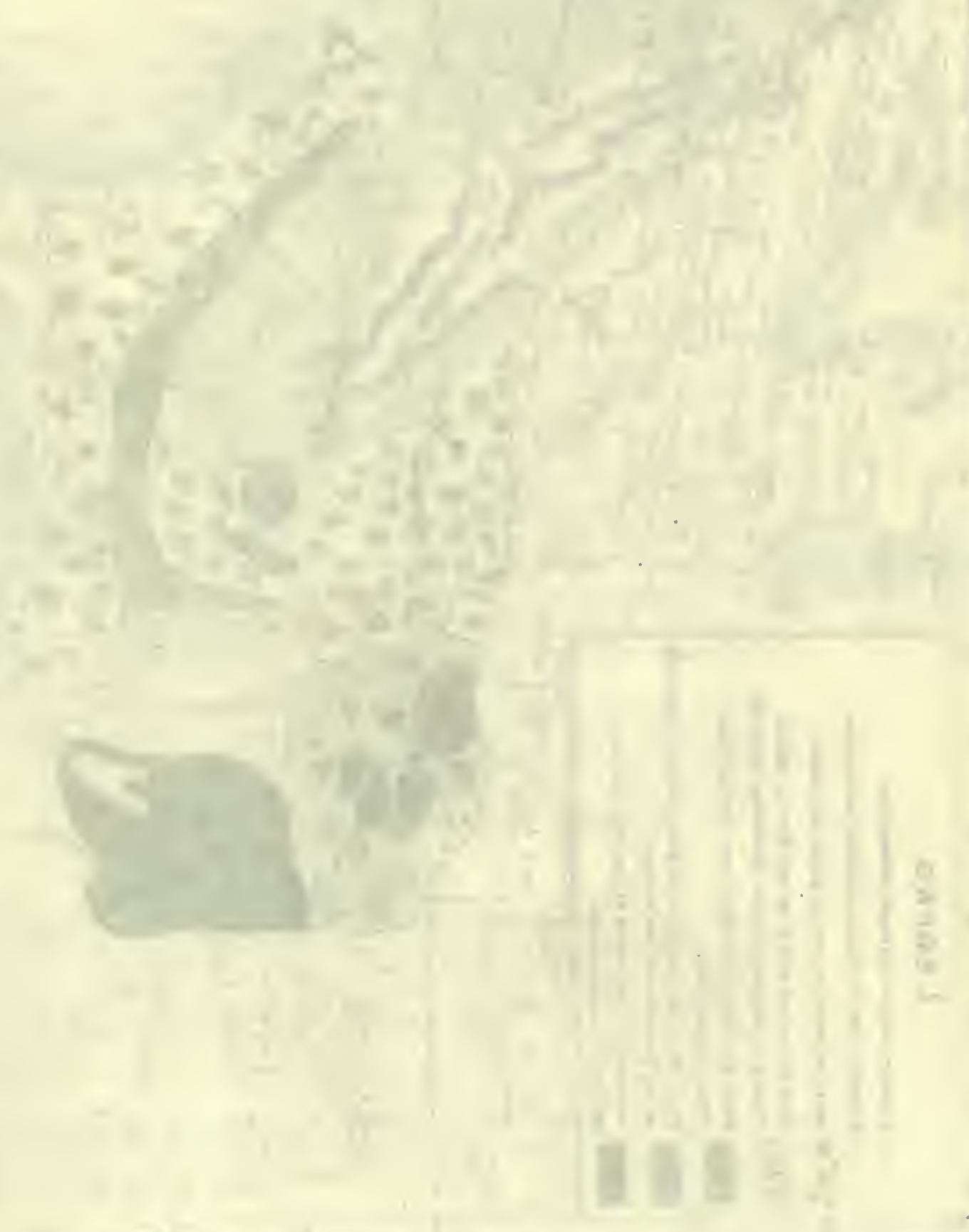


\title{
THE SHORTLEAF PINE.
}

\author{
By Charles Molir, Ph. D.
}

\section{INTRODUCTORY.}

Anong the timber trees of the Atlantic forest region the Slortleaf Pine ranks with the first of those noted for their economic importance. Equally abnndant, distributed over a wider area, and in the quality of its wood but little inferior, it takes its place next to the Longleaf Pine. When maintenance of forest and production of timber nnder a rational system of forestry is to become the rule, this species above all others of southerly distribution will claim attention, for it can be safely asserted that of the coniferous trees adapted to the climatic conditions of the Southeru Atlantic forest, no other can be found of better promise for the production of valnable timber in the shortest time.

\section{IISTOLICAL.}

The Shortleaf Pine, besides furnishing to the colonists the supplies of pine timber required for the construction of their dwellings, formed in early colonial times an article of export to the mother country and the West Indies. Michaux, the younger, writing in the first years of this century, speaks of this timber tree as becoming scarce near the ports. It seems that the specific characters of this tree were but imperfectly uuderstood by the earlier investigators of our silva. They were first accurately defined by Michanx, the fither, who described this tree in his Flora Americana Borealis II, 204 (1803), under the name of Pinus mitis. A still more detailed description was soon afterwards given by Michaux, the soll, in his work on American forest trees (Hist. Arb. Amer., $1, \tilde{\jmath} 2$, t. 3,1810 ), witlı a full account of its value as a timber tree, the qualities and uses of its wood, and all that was known in those days of its place in the forest. Besides the account given of the tree by the Rev. M. A. Curtis, of North Carolina, in his "Trees of North Carolina," little has been added to our kuowledge of this pine until the publication in Professor Sargent's Report on the Forests of North $A$ merica, ${ }^{1}$ of the results of the investigation which the writer had carriel on in the Gulf States, ${ }^{2}$ and Professor Harvey in Arkansas. ${ }^{3}$

For valuable information on the occurrence of this pine on the Atlantic Coast and west of the Alleghany Mountaius, the writer is indebted to the kindness of correspondents active iu the field of botany. In regard to the aren over which this species is fonnd distribnted in the Southern States, the information coutained in the physiographic descriptions of the several connties of the cotton States, in Professor Hilgard's report on cotton production, ${ }^{4}$ werc chiefly relied upon.

\section{GEOGRAPHICAL DISTRIBU'IION.}

The Shortleaf Pine is widely distributed from the Atlantic Scaboard to the treeless plains of the Indian Territory under $95^{\circ}$ west longitude over $23 \frac{1}{2}^{\circ}$ from east to west and $10^{\circ}$ from south to uorth, namcly, from $31^{\circ}$ north latitude to Long Island, $\mathrm{New}$ York, or $41^{\circ}$ north latitnde along the Atlantic Coast, while in the interior it only reaches to $39^{\circ}$ in western Virginia. According to F. A. Michanx, the Shortleaf Pine extended originally as far north as Albany, N. Y. The tree is at present not knuwn in New York outside of Staten Island, and its existence eveu in Pennsylvania is considered

${ }^{3}$ Forest Trees of North America, Tentli Census U. S., IX, 1884. By C. S. Sargent.

2C. Molnr: "Forest Trees of the Gulf Region" (Am. Jour. Forestry, Vol. I, 1883).

3 "Forest Trees of Arkansas." (Ilarvey: Am. Jour. of For., Vol. I.)

4 Hilgard: Tenth Census lieport, Vols. V and VI. 
at. present donbtful. Its uortheru limit west of the Alleghanies ean bo deseribed by a line drawn from the lower part of Wood County, iu West Virginia, to Menifeo County, eastern Kentneky. Beyond the wide gap covered by the deeiduous forests of the lower Ohio Valley and the flood plain of the Mississippi the tree appears on the sontheastern spur of the Ozark Hills in Cape Girardeau County, Mo., latitnde $37^{\circ} 30^{\prime}$, and on the opposite side of the river on the bluffs in Union and Jackson counties, Ill., the line dropping gradually half a degree sonthward to the western linit of its range. (Pl. XIV.)

The Shortleaf I'ine is a tree of the plain and the foothills, in the South rarely aseending to an elevation over 2,500 feet, and at its northern eonfines not over 1,000 feet (in the Ozark Hills). East of the Mississippi River the tree appears sparsely seattered anong the hard-rood trees; along the border of the Carolinian and within the Anstro-riparian zone it becomes more frequent, and often the predominating tree. West of the Mississippi River the Shortleaf Pine finds its region of greatest profusion, forming forests of vast extent on the uplands of the undnlating plain and the table-lands of the hill country, whieh in their timber wealth and econonie importance rival the great lumbering regions farther sonth.

\section{CIIARACTERISTICS OF DISTRIBUTION IN DIFTERENT REGIONS.}

On the Atlantie Coast, from sonthern New York to Virginia, judging from the statements of earlier writers, this treo must have formed originally a considerable part of the forests of eoniferous evergreens eovering the belt of light silicious soils of the Tertiary strata. A. Michaux mentions this speeies "as not found beyond eertain distriets in Comeetient, it being multiplied in the lower part of New Jersey, and still more ou the eastern shore of Maryland and the lower part of Virginia." From the remarks of this writer on the extensive use of the timber of the Yellow Pine (Shortleat) it appears that at the time of his writing-the beginning of this eentury-it must liave been quite abundant in those parts.

This appears elearly by his statement that "in the Northern and Mildle States (of the Atlan. tie Seaboard) and in Virginia, where, to a distanee of 150 miles from the sea, all houses are built of wood, the floors, easings of doors, wainseots, and sashes aro made of this speeies, as being more solid and lasting than any other indigenons wood. In the upper part of the Carolinas the houses are eonstrneted wholly of Yellow Pine, and are covered with it." Further on we Jearn that immense quantities were used in the doekyards of New York, Philadelphia, and Baltimore, and that Yellow Pine lumber formed a considerable part of the exports to Great Britain and the West Indies. Sinee that time this tree has in the region mentioned not only long eeased to be a souree of timber, but lias generally beeome quite searce. Aceording to the information of Dr. N. L. Britton, "it grows on the enast of New York naturally only on Staten Islund, and only about twenty-five trees are to be fonnd in Richmond Connty. It is fairly abundant in the portion of New Jersey from the Raritan River to Delaware liay, forming forests, on a tract not more than 8 miles, and it is also found in Delaware on the same formation outerop of Green Sincl."

With the appearanee of the Iongleaf Pine sonth of Virginia the Shortleaf Pine reedes from the eoast and is found ehiefly in the upper (interior) part of the Sonthern const pine belt, scattered anong the nixed growth of coniferons and deeidnous trees. Above the upler limit of the Longleaf Pine belt the Shortlenf Pine extends, in the Southern Atlantic States, throughont the interior to the lower ranges of the nomutain region.

West of the Alleghany Mountains, in western Virginia and oastern Tennessee, it oeeurs only widely seattered, and hence is practically of no importanee to the lumbering industry.

In North Carolina the Shortleaf Pine is found from the eoast to the mountains, though in the lower distriets enters more rarely into the composition of the upland forests. Aeeording to Hale's report on the woods of Forth Carolina the tree is found in the majority of eounties of the State, bnt is most abmondant in the middle distriet, where, with upland maks and hickories, it is the prevailing tree. It is found about Asheville, at an altitude of 2,500 feet. The Shortleaf Pine used to form 25 per cent or more of the forest growth in many pliees, but such areas are not now frequent anywhere. In the latest report on the forests of North Carolina ${ }^{1}$ it is stated that there

IW. W. Ashe: The Forests, Forest Lands, and Forest Resources of Easteru North Carolina. Bulletin 5, Geol. Survey, N. C., 1891, page 41. 
are possibly $300,000,000$ feet, board measure, Shortleaf Pine standing in the eounties bordering the oak uplauds in the eastern part of the State.

Iu Sonth Carolina this pine is similarly distributed sparingly in the eoast region and more frequent in the midland eountry to the lower mountain ranges.

In Georgia, in the lower part of the eoast pine belt, the Shortleaf Pine is rarely net with. On the sandhills in the eenter of the State, forming the uorthern border of the pine belt, it oeeurs mixed with the Longleaf Pine among the inferior hard-wood timber. In the region of erystalline rocks, whieh embraees the more or less mountainous upper lalf of the State, eovering over 19,000 square miles, with an elevation of not over 2,500 feet, this tree is most frequent, in many parts predominating.

In the three States last named the Shortleaf Piue was originally most abundant in the regions now most densely populated, and henee their supplies of timber are more or less exhausted, most of the so-ealled North Carolina Pine sent to market being Loblolly Pine. Young forests, however, of this tree are seen everywhere on the hills and moutain slopes, where the original timber growth has been removed, and on the worn-out lands abandoned by the eultivator.

In Florila the Shortleaf Pine is eonfined to the uplands along the northern border of the State, seattered among the Longleaf Pine and hard-wood trees. In the northwestern part, it approaehes the seashore within a distanee of from 25 to 30 miles on the isolated patehes of red loam lands, where, together with the Longleaf Pine, it is associated with the Southern Sprueo Pine (Pinus glabra).

In Alabama and Mississippi the Shortleaf Pine is rarely seen iu the lower part of the eoast pine belt, but forms a more or less eouspienous part of the forest eovering of the uplands in the central and upper sectious, and sometimes predominates to sueh an extent over the hard woods as to impart to the woodlauds the somber aspect of a pure pine forest. In the region of erystalline roeks, with its arid ranges in Alabann, coveriug an area a little over 3,000 square miles, between the Coosa River and the southern tributaries of the Tallapoosa, the tree is less frequent than iu the region of the same formation in Georgia, the Longleaf here taking its plaee. In the northern part of Alabama, on the table-land of the Warrior eoal field over an area of fully 5,000 square miles, mostly in forest, the Shortleaf Pine forms a more prominent feature of the growth. This is the ease particularly in the eastern part of this area, where the tree oceupies mostly the summits and steep deelines with a thin, dry soil, while in the deeper and moister soils the Loblolly Pine takes its plaee. In Cullman County, altitude 800 feet, where numerons aere measurements have been marle, rarely over 2,000 feet, board measure, of this timber have been fouud upon one aere, and it ean safely be sail that in the loealities where it is more frequently met with the average stand does not exeeed 1,500 feet to the aere on this table-land. The supplies of Shortleaf Pine timber are rapidly diminishing before the demands of a rapidly inereasing population and of the adjacent eenters of the mining industry, and their total exhaustion is sure to be effeeted withiu a short time.

Wherever the original timber growth has been removed on these mplands the young growth of the Shortleaf Pine is rapidly spreading and predominates over the deeiduous trees. The timber trees of full growth average on these table-lands about 22 inehes in diameter breast high and 95 feet in heiglit, furnishing elear stieks of from 35 to 45 feet in length. Sueh trees have been found with from 90 to 135 rings of annual growth on the stump.

Four trees felled in the vieinity of Cullman showed the following dimensions:

Measurements of four trees.

\begin{tabular}{|c|r|r|r|}
$\begin{array}{c}\text { Diameter } \\
\text { breasthigh. }\end{array}$ & $\begin{array}{c}\text { Length of } \\
\text { tiniber. }\end{array}$ & $\begin{array}{c}\text { Height of } \\
\text { tree. }\end{array}$ & $\begin{array}{r}\text { Rings on } \\
\text { stump. }\end{array}$ \\
\cline { 1 - 2 } Inches. & Feet. & Feet. & \\
22 & 42 & 101 & 109 \\
21 & 41 & 75 & 111 \\
20 & 40 & 87 & 132 \\
24 & 45 & 92 & 120 \\
& & &
\end{tabular}

On the gravelly hills of the northeru extension of the central pine belt in Alabama the Slortleaf Pine beeomes frequently the predominating tree in the forest of oak and hickory. In Lamar County, Ala., and in northeastern Mississippi it forms forests whieh in the latter State give 
rise to a considerable lumbering industry. These forcsts are, however, rapidly decimated along the Memphis and Charleston Railroad, where the products of the inill find ready unarket throughout north Mississippi and at Memphis. Through the northern half of Mississippi, on the divide which separates the waters flowing into the Mississippi River from those of the Tombigbee, extends a region of undulating uplands of oak, hickory, and slortleaf Pine over an area little short of 5,000 square miles; on this long, narrow belt the Shortleaf I'ine can be said to form 12 to 15 per cent of the tree eovering. These forests furnish an ample supply of pine lumber for local demands. It appears, however, that in the eastern Gulf States generally the existing supplies of Shortleaf Pine are scareely sufficient to cover home demand. On these uplands the Shortleaf Pine takes rapid possession of the openings in the forest and the old fields. Here, as has beenelsewliere observed in the central and northern parts of these States, this tree can truly be considered the timber tree of the future. Since it is rarely found in compact bodies, but associated with other trees widely scattered, any attempt at an estimate of the amount of the timber standing in these States must appenr futile. The amount of timber cut eal also hardly be approximated, since it forms only a part of the cut of the mills in these States.

West of the Mississippi River, north of the region of the Longleaf Pine, the Shortlenf Pine is found most abundant and in fullest perfection. It is in these Western forests that the Short. leaf Pine finds its best development, and forms pure forests, extending over many hundreds of square miles with but little interruption. The forests of Shortleaf Pine in northwestern Louisiana, Arkansas, southern Missouri, and northeastern Texas are scarcely surpassed in their timber wealth. The Tenth Census estimates the amount of merehantable timber of Shortleaf Pine standing in 1880 in these Western forests at $87,000,000,000$ feet, board measurc, exclusive of the forests in southern Missouri and the Indian Territory.

In Louisiana the Shortleaf Pine is unequally distribnted over the uplands north of the Longleaf Pine region between the Ouachita River and the eastern boundary of Texas, embracing an area of a little over 8,000 square miles. Along the northern extent of the Louisiann and Texas State line this pine forms pure forests, and also prevails in many localitics on the upland along the border of Arkansas. The resources of pine timber in these mixed forests of oaks, lickories, and Shortleaf Pine, removed as they are from the highways of traffic, have been but slightly drawn mpon.

In Arkansas, in the hilly and mountainous region on both sides of the Arkansas River, over 19,000 square miles in extent, the Shortleaf Pine forms a large part of the tree covering of the siliceous rocky soil and frequently extensive forests on the wide table-lands. On the uplands of yellow loan south of the hills the tree predominates, especially on the low ridges of gravel and, loam, the hard woods encroaching where the soil conditions become more favorable.

The low ridges rising above the Loblolly Pine forests of the flood plain of the Ouachita and Little Missouri rivers are covered with open forcsts almost exclusively of Slortleaf Pine, interspersed with a few White Oaks, Post and Spanish Oaks, rarely above medium size. In the vicinity of Gurdon, in Clark County, upon one acre representing average conditions, 22 Shortlcaf Pines have been counted from 12 to 25 inches in diameter, with no pines of smaller growth among the seatterel undergrowth of dogwood, luckleberries, scrubby oaks, Black Gnm, and hickories. Of this nunber, 8 trees measured from 21 to 25 inches; 6 trees from 15 to 20 inches; 6 trees from 15 to 17 inches and 2 trees 12 to 14 inches in diameter breast high, indicating a stand per acre of about 6,000 fect, board measure.

Five trees, representing the average timber grow th of the forest selected for timber tests, were found of the following dimensions:

Measurements of five trees.

\begin{tabular}{|c|c|c|c|c|}
\hline $\begin{array}{l}\text { Diameter } \\
\text { breast high. }\end{array}$ & $\begin{array}{l}\text { Length of } \\
\text { timber. }\end{array}$ & $\begin{array}{l}\text { Height of } \\
\text { treo. }\end{array}$ & $\begin{array}{l}\text { Rings on } \\
\text { stump. }\end{array}$ & Sapwood. \\
\hline $\begin{array}{r}\text { Incres. } \\
20 \\
24 \\
19 \\
18 \\
25\end{array}$ & $\begin{array}{r}\text { Feet. } \\
60 \\
47 \\
40 \\
36 \\
45\end{array}$ & $\begin{array}{r}\text { Feet. } \\
110 \\
106 \\
109 \\
05 \\
117\end{array}$ & $\begin{array}{l}120 \\
132 \\
102 \\
120 \\
143\end{array}$ & $\begin{array}{r}\text { Inchet. } \\
2 \\
2 \\
3 \\
3 \\
3\end{array}$ \\
\hline
\end{tabular}

On the arid hills of flinty sandstone the trees are of inferior growth, as observed in Hot Springs County, in the vicinity of Malvern. On their steep slopes the pines are rarely found to exceed 18 
inches in diameter breast high and 75 feet in height, elear of limb for the length of about 35 feet. In a number of trees from 120 to 125 rings were connted on the stump. The wood produced on these hills is of a lighter color, less resinous, and of a fine grain. Specimens of tinished lumber from such timber resemble somewliat that of the White Pine. The hard-wool trees, mostly Spanish Oak and Post Oak, scattered beneatl the pines, are scrubby and of no value for their timber.

Along the railroad lines the forests liave become exhausted for a distance of from 5 to 10 miles on either side, and the timber from the virgin forests is conveyed to the mills on steam trannoads. It appears that of late years about $550,000,000$ to $560,000,000$ feet, boarl measure, of pine timber are sawn annually in Arkansas sonth of the Arkansas River. In this amount the Loblolly Pine lumber is included, which is indiscriminately sawn and put with the Shortleaf Pine on the market as Arkansas Yellow Pine. The bulk of the product of the sawmills in this section is shipped by rail to the markets of the Northwest.

In the northern part of Texas, east of the prairie region, from the Red River Valley to the uorthern border of the Longleaf Pine region (under latitude $32 \circ \mathrm{N}$.), extends an area of oak, hickory, and Shortleaf Pine uplands, stated in the agricultural report as covering 35,000 square miles. In the southern extent of this area the districts where the Shortleaf Pine prevails are popularly known as the "Pineries." Nortlr of the Sabine River, from Longview through Cass and Bowie counties, the Shortleaf Pine forms compact forests over many hundreds of square miles. Near Bevins, in Cass County, where the pine forests were more closely investigated, the molerately dense timber growth eovers the undulating country dowu to the lowlands of the Red River in Louisiana. The sandy gray loam forming the ratlier compact soil of the surface is underlaid by laminated stiff clayey marls, which at the depth of about 4 feet become quite impervious to water. Blackjack, Spanish Oak, and Post Oak of stunted growth are scattered beneath the pine. The pine appears to be of slower growth; trees of full size-that is, from 20 to 24 inches in diameter-were found to have reached an age of from 195 to 210 years. The upper part of the timber of sucls old trees is frequently affected by rot, a defect undoubtedly to be ascribed to the cold, inpervious subsoil.

From 6,000 to 7,000 feet of merchantable timber are claimed as an average stand for these timber lands. Every tree above 10 inches in diameter at breast height is cut for the mills. After the removal of the pine the hard woods gain rapidly in the rate of their growth, soon shading the ground completely. Young pines are rarely seeu in the natural openings, the seedlings being too frequently destroyed by fire. In the elearings, where the original tree growth has been completely removed and the pine takes quick possession of the ground, the second growth, it not killed outright by the fires which again and again devour the surrounding tall weeds and broom grasses, lecomes too severely injured to be of any promise.

Four trees, selected as representing fairly the average merchantable timber of the Shortleaf Pine forests of northeastern Texas, showed the following record:

Measurements of four trees.

\begin{tabular}{|r|r|r|r|r|}
\hline $\begin{array}{r}\text { Diameter } \\
\text { breast higb. }\end{array}$ & $\begin{array}{c}\text { Length of } \\
\text { timber. }\end{array}$ & $\begin{array}{c}\text { Height of } \\
\text { tree. }\end{array}$ & $\begin{array}{c}\text { Kings in } \\
\text { stump. }\end{array}$ & $\begin{array}{c}\text { Sapwood } \\
\text { on stump. }\end{array}$ \\
\cline { 1 - 2 } Inches. & Feet. & Feet. & & Inches. \\
24 & 36 & 120 & 105 & 3 \\
23 & 40 & 109 & 205 & 3 \\
18 & 45 & 95 & 102 & 5 \\
17 & 42 & 94 & 102 & 58 \\
\hline
\end{tabular}

The forests of Shortleaf Pine near Longview, which was in 1880 the site of a most active lunber industry, have been nearly exhausted, and with diminished supplies aloug the New Orleans and I'acific Railway the business has greatly dechined. The annual output of the 30 inills situated along this road, and its branch from Carthage to Panola, does not at present in the aggregate exceed $70,000,000$ feet, board measure. From the information obtained in 1892 it appears that in 1891-92, 200,000,000 feet, board measure, were handled in Texarkana, the product of the mills at that place and immediate vicinity, and also that the shipments of the mills south of the Red River in the same year reached about 105,000,000 feet, board uneasure.

$7092-$ No. 13 
In Missonri the rugged hills and table-lands of the southern slope of the Ozank Mountains, rising to an elesation of Irom 800 to 1,000 feet, are covered with forests of Shortleaf Pine, which, ronghly estimated, extend over little more than $3.000,000$ aeres. In the eomties bordering on the Arkansas State line (Terry. Ozark, mul Donglas eonnties) the pine is sail to yield on the average not over "2,000 feet of timber to the acre. 'The forests in the basin of the Current and Blaek rivers sre leavily timbered, as observed at Grandin. The density of the timber growth varies, however, on these broken lands with the soil conditions, a fuet demonstrated by actnal measurements on several plats, upon which the amount per aere varied from 3,000 to 15,000 feet of timler. After years of experienee, the average yich of the timber lands of the Grandin Lumber and Mining Company is estimated at 6,000 feet of merehantable timber to the aere, ineluding trees of 10 inclies in dianeter.

The trees felled to serve as material for the United States timber tests, and fairly representing the average timber growth, showed the following record:

Mcasurements of fire trees.

\begin{tabular}{|r|r|r|r|}
\hline $\begin{array}{c}\text { IViameter } \\
\text { lireast lilgh. }\end{array}$ & $\begin{array}{c}\text { Lengt li of } \\
\text { tinber. }\end{array}$ & $\begin{array}{c}\text { Ifeight of } \\
\text { trce. }\end{array}$ & $\begin{array}{c}\text { Ilugs on } \\
\text { stump.a }\end{array}$ \\
\hline Inches. & Feet. & Feet. & \\
31 & 40 & 103 & 174 \\
20 & 50 & 99 & 150 \\
17 & 35 & 92 & 140 \\
22 & 40 & 88 & 180 \\
24 & 50 & 109 & 218 \\
\hline
\end{tabular}

a Sapwool on radins of stump averaging 21 inches.

The timber from these most northern of the forests of Shortleaf Pine is remarkably free from resin, of a fine, close grain, almost white, and claimed to be lighter and softer than the timber grown farther south, and like the timber oceasionally found on the dry, rocky hills in Hot Spring County, Ark., resembling the wood of the White Jine. In these forests the fine tall pines tower high above the stunted Scarlet, Black, and White Oaks and hickories, bit the growtl of these hard wools almost completely overpowers the seeond growth of pine.

In close conneetion with the great markets of the North, and nearest to the timberless region of the Northwest, the manufaeture of lumber in this region is fully developed. Aceording to information received at Grandin, the output of the mills locater aloug the Current River Valley Jailroad, the Iron Mountain Railway, the Kansas City, Fort Seott and Memphis Railroad, and the Cape Girardean and Soutliwestern road amounted for the year 1891-92 to fully $300,000,000$ feet, board measure. At snch rates the depletion of the timber wealth of this forest is to be expeeted before another generation las jassed away.

Linder the existing method of exploitation, which involves the almost total destruetion of the sualler timber growth, nothing remains to be depended upon for the fintnre. Considering the difficultics in the way of their natural renewal, there is no hope left for their restoration on these knolls. The dense undergrowth and brush of decidnous trees and slirubs which eompletely shade the soil, the roeky surface being hidden by an abmdant and inflammable leaf eovering, deprives the pine of every possibility of reprodnetion by nat mal seeding, even if the seedlings conld eseape destruction by fire.

According to the census of $1850,{ }^{1}$ extensive bodies of Shortleaf Pine timber exist in the eastern part of the Indian Territory. It oceurs mixed among the liard woods on the higher ridges of the timber belt in the Choetaw Nation, 60 miles in length, and eonsiderable bodies of Shortleaf l'ine timber in belts of from 10 to 30 miles in length and 2 to 4 niles wide are fonnd on the tribntaries of Grand River in the Cheroke Nation, and in a large body of timber extending for 25 miles west of lienm this tree appear's to reach its westeru limit.

The great importanee of the forests of Shortleaf Pine to the industrial and commercial interests of the country west of the Mississippi River, and to the development of the andjacent timberless Stutes and Territories, is foreibly exhibited by the enormous produetion of lumber for the past ten years. During the year 18:1-92 at a low estimate not less than 1,270,000,000 feet, board measure, 
have been shippel from points in Texas, Arkansas, and southern Missouri to Northern markcts. This amount may be swelled by the proluction east of the Mississippi to round numbers of $1,500,000,000$ feet, board incasure.

As stated before, an estimate of the timber of this speeies standing is impossible on account of its seattered distribution and prevalent oeeurrence in mixed growths. Bnt eonsidering the extent of the areas within whieh it oeeurs and the average cut on the same, or comparing with the amounts of Longheaf Pine, whieh on account of the compact bodies in which it oceurs, ean be more readily approximated, it is safe to assume that very mueh less than $100,000,000,000$ feet remain available, while the ent can be roughly cstimated at 1,500,000,000 fect, board measure.

\section{l'RODUCTS.}

Among the eoniferous trees of eastcrn North Ameriea the Shortleaf Pine stands ncxt to the Longleaf Pine in importance to the lumber industry and in the value of its timber. Freer from resinous matter, softer, morc easily worked, not less susceptible of a good finish, the lnmber of the Shortleaf Pine is often preferred by tho eabinctmaker and the house earpenter to that of the Longleaf Pine. Less tenacious, and of less power of resistanec under strain, it is principally used for the lighter framework in buildings, for weatherboarding, flooring, cciling, wainscoting, eases for windows and doors, for frames and sashes of all kinds, and for shingles. Most of the dwellings loeated within the distriets where this tree prevails arc built almost entircly of Shortleaf Pine lnmber, which bears ample testimony to its wide uscfulness. It is also extensively employed iu car building, for cross-ties, and in the manufacture of furniturc.

\section{NOMENCLATURE AND CLASSIFICATION.}

This speeies, like all of the sanc genus of a decidedly Southern distribution in the $\Lambda$ tlantic forcst, belongs to the section Pincester as defined by Engelmann, with cones of tough, woody seales their exposed ends thickencd by an umbonate swelling (apophysis), whieh is armed with a wcaker or stronger deciduous or persistent prieklc or mucro. It was first deseribed by Miller in the ycar 1768 as Pinus echinata, ${ }^{1}$ and under that name reeognized by the earlicst writers on North Ameriean forest trecs; ${ }^{2}$ it was subsequently named by an obseure writer Pinus virginiana var. cchinata, Dn Roi. ${ }^{3}$ Michaux described this trec in his North Anerican Flora ${ }^{4}$ under the name of Pinus mitis, which received general recognition and by which it is known to botinists to the present day. Pinus variabilis, the nane under which it was described at about the same time by Iambert, ${ }^{5}$ was adopted by Wildenow, and following that author by Pursh, Nuttall, liliott, and a few others of the writers on the botany of this eomtry. In following strietly the rule of priority, at present most strongly advocated as the only measure to avoid further the confusion arising from an endless number of synonyms, Pinus mitis, the name under whieh it is generally known, will have to be abandoned, and the morc obscure onc, Pinus echinata, under which this specics was first puiblisherl, restorerl.

Great confusion is eansed by the various appellations this tree has reeeived in the English vernaeular, being indiscriminately ealled Shortleaf Pinc, Ycllow Pinc, and Spruce Pine, although most widlely known under the first of these names, and in the unarkets it is now somewhat doubtfully established muder the name of Ycllow P'ine. In the States of the lower Sonth it is frequently confounded with the Loblolly Pine, as the timber of the two is often, if not mostly, mixed. MI. A. Curtis, in his "Trees of Nortil Carolina," selceted for this" tree the name of Yellow Pinc, strongly recommending its general adoption in order to introducc greater uniformity in the designations of our forest trecs. Unfortmately the same name is in many of the Southern lumbering districts bestowerl npon the Longleaf Pinc, particularly when the timber is spoken of. It is often quite inpossible to deternnine to which of the two speeies the timber is to be referred when under that nane it is quoted in the reports of the lumber markets.

\footnotetext{
Miller, Gard. Dictionary, 8th ed., London, 1768.

2 Marshall, Arbustrun Americanum: Philadelphia, 1785.

${ }^{3}$ Du Roi, Harb. Baumz. Nordarn. 1771-72.

'A. Michaux, Flora Boreali-Americana. I'aris, 1803.

${ }^{B}$ Lanıbert, Description of the Genus l'inus: (od.) 1803 and (ed.) 1824.
} 
EXPLANATION OF PLATY XV.

[Figures natural size, except where otherwise noted.]

Fig. a, branch from a lower linb bearing male infloreseence with flowers in a dense cluster (first week of April, southern Alabama); $b, c$, branch with two snbterninal aments of female flowers below whieh are two imuature eones of one season's growth; $d$, detached male flower showing basal involucral seales, magnified 3 dianeters; $e$, gerninating seed (February); $f$, same scedling one month later (March) with 7 cotyledous in the unidst of which the terminal bud shows the prinary leaves appearing; $g$, seedling abont tho elose of the first season with terminal eluster of true (seeondary) leaves, below whieh aro seen tho withered primary leaves; $h, i$, transverse seetion throngl base of two and threo leafed leaf bundle, magnified 50 diameters, showing onter small lypodermal cells, the stomata appoaring as marginal white spots; next a broad band of large in-walled parenehymatous cells bearing ehloropliyll, within which, at the angles of tho leaf, resin dnets appear as largo openings; the dark areas in the center are fibro. vascular bundles surrounded by a single row of thin-walled cells (bundlo sheath). 

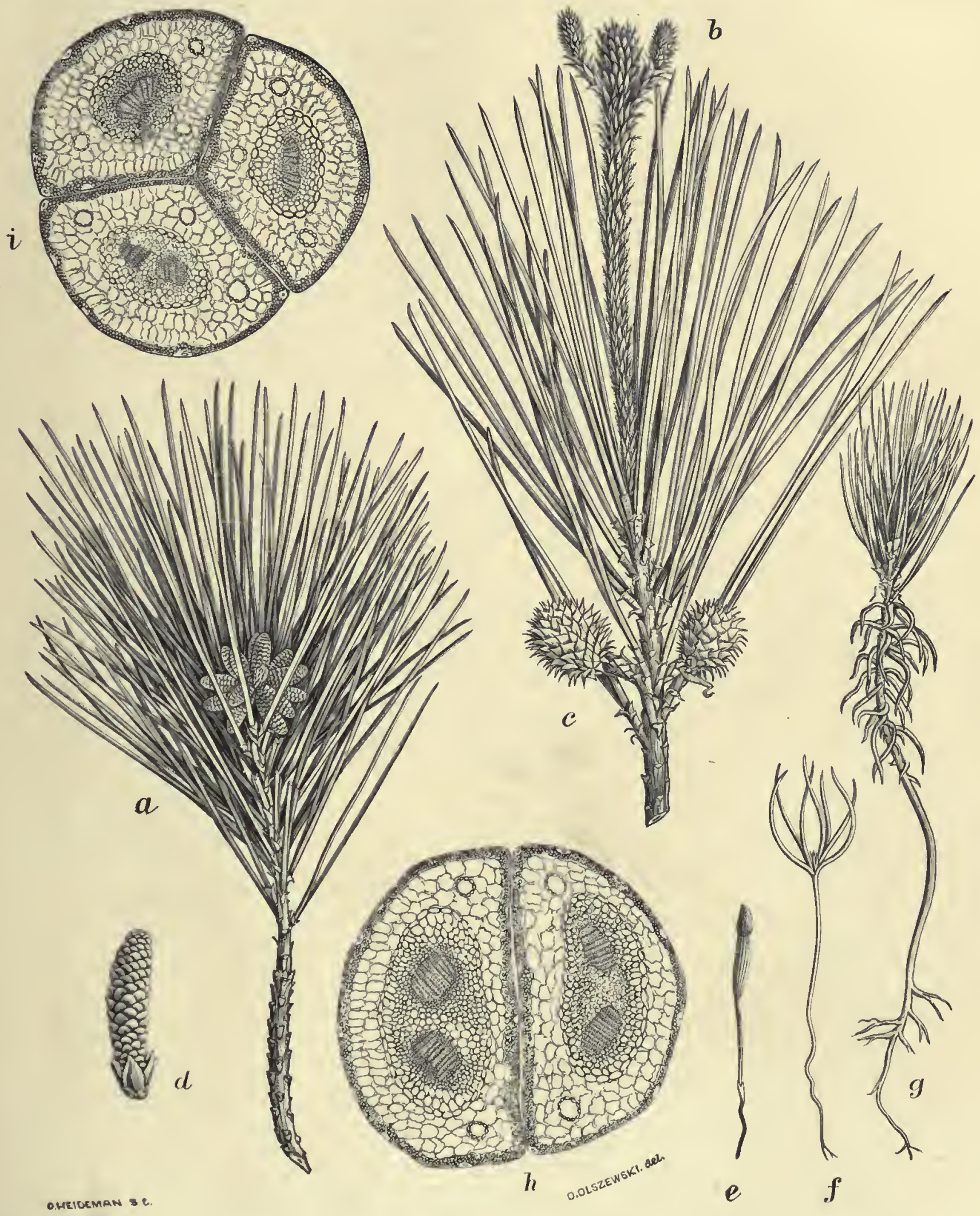

oreigeman se.

Pinus echinata: Seedlino, Male and Female Flower, and leaf Sections. 

Under the name of Spruce Pine, in the extreme Southern districts, it is invariably confounded with the true Southern Spruce Pine (Pinus glabra), the species which in several points it elosely resembles and to which it is most closely related.

\section{BOTANICAL DESCRIPTION.}

Leaves mostly 2 (sometines 3 ) in a short sheath, 3 to 5 inches long; cones $1 \frac{1}{2}$ to 2 inches long, oval or somewliat conical; scales with a short, tender, straight, and finally incurved prickle, light browll. Seeds rather small, two-fifths of an inch long, by one-tenth to one-eighth of an inch wide, with dark, seattered or confluent specks; the wings are reddish brown and about one-half of au incli long. The young shoots are of a glaucous violet color. The bark of mature trees is rather thick and broken up in squarish plates. The different general appearance of the tree will almost always serve to quickly distinguish it from the closely related Scrub Pine (Pinus virginiana) which is distinguished by its shorter and more rigid leaves. Any doubt can be removed by trying the trigs; those of the Scrub Piuc are tougl while those of the Shortlcaf Pine snap off readily. The bark is of a light reddish brown color, and on the lower part of the trunk in full-grown trees three-fourths to fully one incls thick crossed by deep furrows, aud flaky.

The limbs are arranged in more or less regular whorts, under full exposure, forming a crown with the outlinc of a truncated pyramid, by which the tree can be recognized from a distance and distinguished from kindred species with which it happens to be associated. The oldest and stoutest limbs are rarely over 20 to 25 feet in lengtl, and are somewhat drooping.

It is indeed a beantiful tree, with its stately, gently tapering trunk and its finely shaped full crown elothed in all abundance of foliage, bearing the stamp of thrifty and vigorous growth.

Leares.- The secondary or foliage leaves are found mostly 2 in a sheath, and on shoots of vigorous growth often 3 are found iu a bundle; occasionally whole trees are seen with 3 leaves in a sheath and in some rare instances on young trces even 4 liave been counted (Pl. XVI, $g, h$ ). The leaves vary from 3 to 4 inches and a little over in lengtlı; they are slender, about one-cighteenth of an inclı wille, strongly concave, slightly twisted, faintly serrulate, and abruptly sharp pointed, while young of a yellowish and later on of a dceper green color. In the cross section $(\mathrm{Pl} . \mathrm{XV}, h, i)$ they present a semicircular outline; examined under the microscope they show on both sides about ten rows of minute stomata (breathing porcs) the small epidermal cells underlaid by a single layer of rather thin-walled hypodermal or strengthening cells; in the specimens examined from 3 to 4 peripheral resin ducts were found, the bundle sheath consisting of a single row of cells. The sheath invests the leaves closely and rarcly exceeds at any stages of growth thrce-sixteenths of an inch; the leaves are shed dnring the latter part of their second year.

The bract-like seales $(\mathrm{Pl} . \mathrm{XV}, b . c$.$) , modified prinary leaves, which densely cover the young$ shonts and in the axils of which the foliage leaves are produced, are while young of a grayish color, closely appressed, lanceolate, acmininate, and fringed; with the subseqnent development of the foliage leaves and the increase of the shoot in length, their tips become dried and are cast off: As the tender shoots become hardened they assume a glancous purplislı color.

Flowers. - The flower buds make their appearance during the latter part of the winter and begin, ill stations of southern latitudes, to open near the end of March (Baldwin County, Ala., March 26), and farther north from three to four wecks later (Cullman, Ala., April 28). The staminate flowers are closely sessile, to the number of fiftecn to twenty surrounding the terminal bud (Pl. XV, $t$ ), which at the time has searcely grown to the length of an eighth of an inch. The staminal columı, of a pale purplish color, does not exceed three-fourths of an inch in length, is less than one-cightl of an inch in thickness, aud is surrounded by eight or nine decussate scitles, those of the first pair being strongly keeled aud scarcely half the size of the others (Pl. $X V, \lambda)$. The crest of the authers is nearly circular and sliglitly denticulate. The male flowers are sher inmediately after the discharge of the pollen. The female flowers are nnited in an oblong, olstuse, short-stalkel catkin of a delicate rose-pink color, about one-fourth of an inch in lengtli. They are rarely single, but inostly from two to four, produced closely below the apex of the youngest shoot $(I) \perp \vee V, b)$. The stipe of the catkin, not over three-eighths of an inch in length, is iuvester by twenty'to twenty.four liyaline lanceolate, pointed, involncral scales, those inmerliately surrounding the flowers being widely spreading. The bracts subteuding the carpellary scales cover the latter to the base of their long, subulate, erect tips. 
EXPLANATION OF PLATE TVI.

Fig. $a$, branch with mature closed cones (October of second season); $b$, matnre cone; $c$, cone scale, outer or dorsal view showing apophysis; $d$, ventral view of the same with seed in place; $e$, seed detached from wiug; $f$, sced with wing intaet; $g$, leaf forms, two and three leafed bundles. 


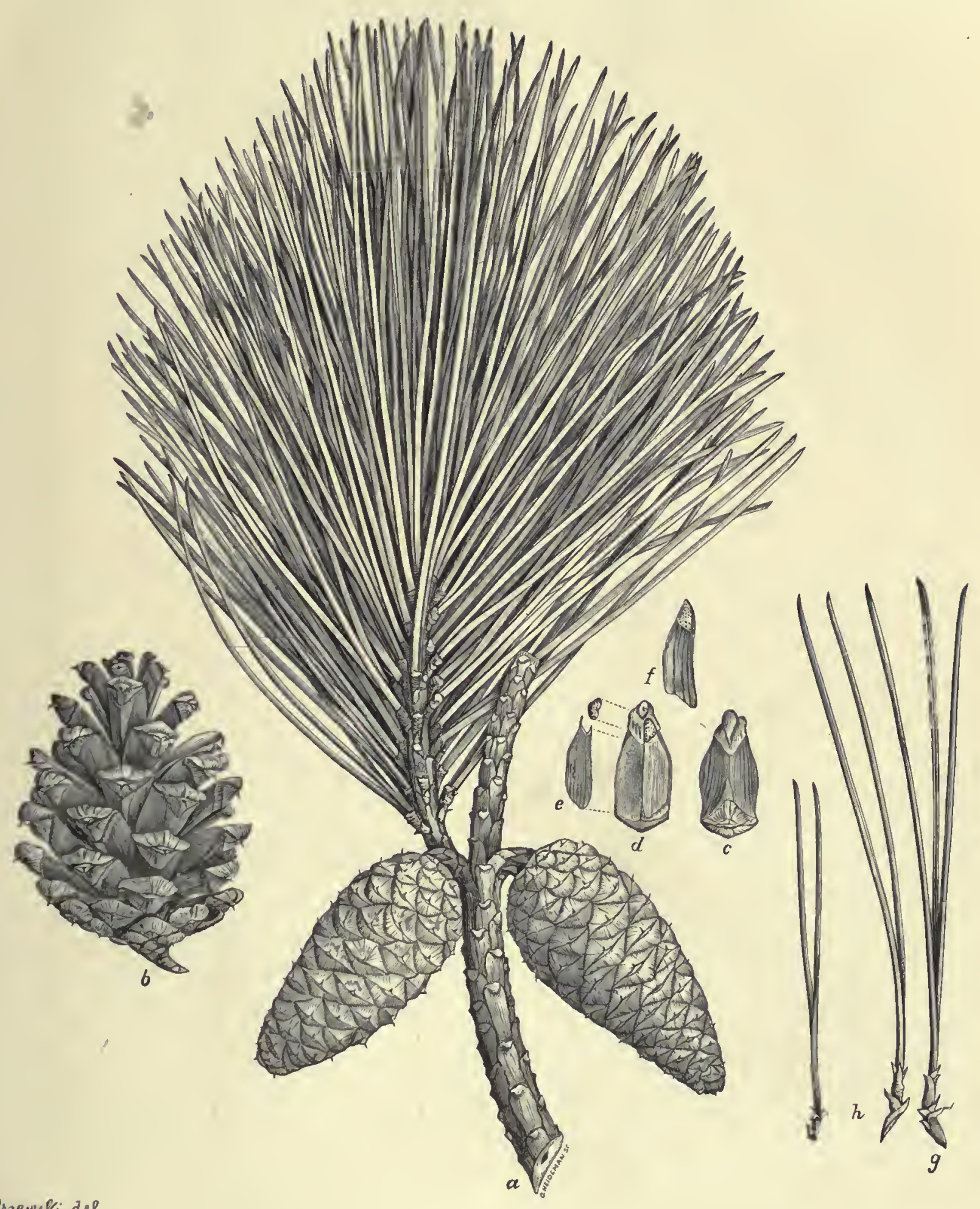

D.Glozewcki del 

After fertilization has taken plaee the shoots bearing the fertile flowers inerease rapidly in length. Fertile eatkins are frequently found on the older branehes, produeed on branehlets froin adventitions buds. The tree begins to prodnce flowers when from ten to twelve years old, aeeording to exposure; male flowers have been observed one or two seasons earlier.

Cones.-Every season eones are produeed in great abundanee. The eonelets of the first year, borne on a short, horizontal stalk, are oval in shape, seareely one-half an inch in length, the squarrose tipsiof the scales giving them the eehinate appearanee from whieh the botanieal name first given to this speeies was undonbtedly derived (Pl. XV,c).

Fully matured by the end of the second year, the eones are nearly sessile, oval, of dull or leather brown eolor, $1 \frac{1}{2}$ to rarely 2 inehes long, and when open, nearly as wide; they are frequently smontlı (Pl. XVI, $a, b$ ). The seales are hard, with a slightly swelled apophysis, devoid of or armed with the weak, more or less deeiduons priekle (Pl. XVI $c, d$ ). The eones open early in the fall, and remain, after the discharge of their seeds, for several years on the branehes. In eonsequenee, the older trees are eovered with them throngh all seasons.

Seed.-The Shortleaf Pine produees seeds in greatest abundance; its erops seem never to fail. The seeds are small, triangalar, three-sixteenths of an ineh long by one-eighth of an ineh wide, the hard, roughish testa marked with three indistinet ridges and more or less with eonflnent speeks; the wing is of a light, reddish brown, lialf an ineli in length and deeiduous during germination $(\mathrm{Pl} . \mathbf{X V}, e, f)$. The seeds retain their vitality for several years; fresh, they will germinate in from ten to fifteen days. The number of seeds to the onnee is abont 5,000; wafted by the wind over wide distances and germinating early during the first days of spring, their offspring are fonnd to take possession of every opening in the forest and of the old fields in loealities favorable to their growth.

THE WOOD.

The wood of Shortleaf Pine resembles that of the Loblolly in almost every respect. The sapwood is elearly defined, being quite broad, and even in very old trees forms fully one-half of the total volume of the trunk. In thirteen trees one liundred to one hundred and fifty years old, the average willth of sapwood was fonnd to be about 4 inehes, while even in trees over one hundred and fifty years old its average width was 3 inehes. In the former ease, the sapwood formed 65 to 60 per cent of the volume of the logs; in the latter, 50 to 55 per cent, while in a set of trees fifty to one hundred years old it formed fnlly 80 per eent of all the wood. The ehange from sapwood to hardwood proeeeds inueh as in Loblolly Pine. It begins when the tree (or any disk) is about twenty-five to thirty years old, and is retarded more and more with age, so that in old trees as many as eighty or even one hundred rings are eounted in the sapwood, while in young and thrifty trees not more than thirty to forty may oecur.

In keeping with the large anount of sapwood, the weight of green Shortleaf Pine is rather great, varying, for entire logs, from 45 to 55 pounds per enbie foot, eommonly approaehing 60 pounds in the largely water-filler onter portions of the sapwood.

Wheu kiln dried, the wool of trees one lundred to one hnndred and fifty years old weighs on the average abont 32 pounds per enbie foot. As in other pines, the butt is 15 to 20 per eent heavier than the top, and the wood of the inner forty to fifty rings excels in weight and strength the woorl of the outer parts of old logs. As was stated for Loblolly, the sapwood inay be light, heavy, weak, or strong, aceording to the age of the tree from whieh it is obtained. As might be expected from the great range of distribution of this tree, its wood, like that of Loblolly, varies within very wide linits. Speeinens from Missouri (near its northern limits) are generally lighter and less resinous than those from farther south, and frequently resemble the wood of the Norway P'ine, while many select speeimens from the Gulf and Sonth Atlantie States rival in weight and strength the best grades of Longleaf Pine. In its strength, as in its weight, the Shortleaf follows Loblolly Pine.

The average of a large series of tests furnishes the following average values for dry pieces of this species:

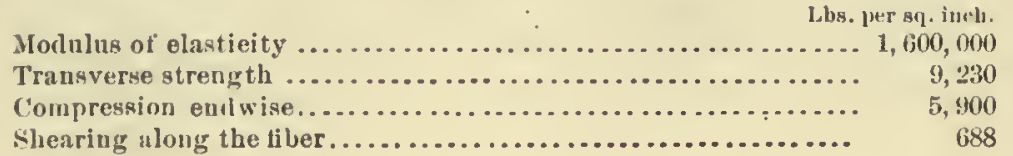


As the average weight of this series was 35 pounds per cubic foot, or abont 16 per cent heavier than the average weight inrolving all parts of all the trees, these figures should be redueed by that per cent to represent the true average for the wood of the species.

In drying, 100 pounds of wood lose from 40 to 50 pounds of water, the bulk of whieh comes from the sapwood, which eontains 60 per ecnt and inore, while the heartwool, like that of most pines, eontains about 25 per eent.

The shriukage in volune eonsequent on drying amounts to about 11 per cent. It is about $1: 3$ per cent in the wood of the butt and about 10 per eent in that of the upper logs, varying in this respect direetly as the weight of the dry wood. Of the 11 per eent, about 8 per cent fall to the tangent or oecur along the rings and 3 to 5 per eent along the radius.

The strueture of the wood of Shortleaf Pine is essentially the same as that of Ioblolly. Snm. merwood and springwood are sharply defiued. The proportion of the former to the wood on the whole varies, as in Loblolly, in the same nanner as the weight of the wood, being greater in the butt than top, greater in the wood of the inmer rings than in the wood farther out, and greatly rednced in all eases where the growth of the tree is suddenly retarled by unfavorable seasons, bnt is otherwise quite independent of the width of the rings.

For details of stmeture, eonsult the eomparative study of Mr. Roth, appended to these monographs.

\section{PROGRESS OF DEVELOPMENT.}

The seeds begin to swell and to germinate in the early days of spring. In Mobile Comnty, on the end of the first week of March, the plantlets had their cotyledons fully unfolded, which were found to vary from six to seven in number, with the lower (hypoeotyledonary) part of the axis from $1 \frac{1}{2}$ to 2 inehes long, the rootlets being somewhat less in length ( $P l$. X V $\left., e, g\right)$. The development of the npper part of the axis (eauliele) from the terminal budlet and of the primary acerose leaves proceeds now rapidly. These primary leares succeding the cotyledons are stiff and sprearling, about three-fourths of an ineh long and covering the stem densely (Pl. XV, g), remain during the first season, withering from below duriug the warmer part of the season. By the elose of the first season the canliele or first shoot has attained a length of fiom 3 to 4 inches. On the shoot of the sceond season (rarely before) the secondary leaves, whieh constitute the foliage, make their appearance from the undeveloped branchlets in the axis of the primary leaves (Pl. XV, $g$ ). At the end of the second year the plants are $i$ to $S$ inches high, with a taproot 2 to 3 inches long. During this season adventitious buds appenr at the eollar of the stem, which bring forth vigorons sprouts, partieularly if the stem has sustained the slightest injury. These shoots are covered with prinary leaves, whieh are retained for one season. They are apt to form strong branches before the tree has reaehed its fourth or fifth year; such branehes, whieh are produced profusely from the stumps of larger trees, scarcely survive another season. It is rarely that branehes are prodnced in the second year, the first branches appearing generally in the third season in whorls of three to four. In the third year foliage leaves alone are produced in the axils of scales with their bases elose to the stem. At the elose of the third year the plants are from 12 to 18 inches high. Now the development of the root system advances rapidly; the taproot being by this time about 8 or 10 inehes long, with strong lateral roots often donble that length. Both taproot and lateral roots are finally vigorously developed, penetrating deep into the ground, so that trees of this species are rarely blown down by winds. At the end of the fourth year the plants are from 2 to 3 feet high, with the stem at best from five-eighths to seven-eighths of an inch thick.

The branches of the whorls begin now in their turn to develop branchlets in whorls of seeondary order. The development of the primary axis and its branch system proceeds henceforth in the regular acropetal orler. Is in all pines, the shoot of the main axis takes the lead in rapidity and vigor of growtl. liy a munber of measurements made at Culluan, north Alabana, of trees from the openings in the forest, as well as fron clearings, it was found that ly the end of the fifth year they had attained a height varying between 3 and 5 feet, rarely over, the stem being from five-eightlıs to seven eighths of an inch in thickness; by the end of the sisth year, tiom 6 to 9 feet high and from one hall to " inches in cliameter; and at the tenth year, from 10 to 16 foet high and firom 2 
to $2 \frac{1}{2}$ inches in diameter. At the age of fifteen to twenty years, with a total height of from 20 to 30 fect and a diameter breast high of 4 to 5 inches, the crown of the tree occupies from one-half to five-eighths of its height. Henceforth throughout the period of quickest growth its rate is greatly influenced by conditions of light and soil. At the age of fifty years the lieight of the trees varies between 40 and 60 feet and the diameter breast ligh between 10 and 14 inches. About this age, or perhaps a short time before, the licight growth begins to decline and the branches become somewhat reelining below and spreading toward the top, and consequently the head of the tree becomes more ronnded in outline. Betwcen the ages of sixty and seventy years the trces are from 50 to 70 feet high and from 12 to 15 inches in diameter, with the trunk clear of limbs for 30 to rarely over 40 feet. From this period on the growth proceeds at a slower rate. On reaching its one hmudredth year the tree has attaincd a height between 90 and 95 feet and a diameter of from 16 to 19 inches at most. Having now passed its period of vigorous life, the growth is henceforth insignifieant. Between the ages of one hundred and twenty and one liundred and thirty years trees were found 90 to 110 fcet high and from 18 to 24 inches in diameter. The oldest tree encountered in the measurements, with two hundred and eight rings of annual growth in the stump, scarcely exceeded 109 feet in height and measured 24 inches in diameter. The largest tree felled was 117 fect high and 25 inches in diameter, with one hundred and forty-three rings in the stump. Occasionally trees arc found of a diameter exceeding 3 feet, but such are exceptional.

Tanue I.-Growth of Shortleaf Pine (Pinus echinata), from eight to fifly years.

\begin{tabular}{|c|c|c|c|c|c|c|}
\hline $\begin{array}{l}\text { Number of } \\
\text { tree. }\end{array}$ & $\begin{array}{l}\text { Rings } \\
\text { in } \\
\text { stnmp. }\end{array}$ & $\begin{array}{l}\text { Diame- } \\
\text { ter at } \\
\text { breast } \\
\text { high. }\end{array}$ & $\begin{array}{c}\text { Height } \\
\text { to } \\
\text { first } \\
\text { limb. }\end{array}$ & $\begin{array}{c}\text { Total } \\
\text { helght. }\end{array}$ & Locality. & Remarks. \\
\hline $\begin{array}{l}1 \\
2 \\
3 \\
4 \ldots \ldots \ldots \ldots \ldots \ldots\end{array}$ & $\begin{array}{r}8 \\
8 \\
9 \\
10 \\
10\end{array}$ & $\begin{array}{c}\text { Inches. } \\
2 \\
2 \\
17 \\
29 \\
21\end{array}$ & 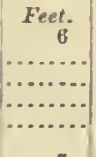 & $\begin{array}{l}\text { Feet. } \\
11 \\
11 \\
11 \\
17 \\
11\end{array}$ & 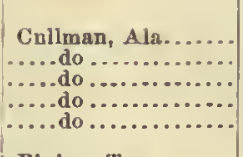 & $\begin{array}{l}\text { Clearing made in } 1879 \text { for pasture in dense pine thicket. } \\
\text { Do. } \\
\text { Do. } \\
\text { Rocky hillside, border of thicket. } \\
\text { lacky hillside in dense thicket of vigorous growtl, youngest shoot, } \\
19 \text { inches. }\end{array}$ \\
\hline $\begin{array}{l}173 \ldots \ldots \ldots \ldots \ldots \\
138 \ldots \ldots \ldots \ldots \\
9 \ldots \ldots \ldots \ldots \ldots \\
137 \ldots \ldots \ldots \ldots \ldots \\
6 \ldots \ldots \ldots \ldots \ldots \\
5 \ldots \ldots \ldots \ldots \ldots \ldots \\
1 \ldots \ldots \ldots \ldots \ldots \ldots \\
10 \ldots \ldots \ldots \ldots \ldots\end{array}$ & $\begin{array}{l}12 \\
11 \\
12 \\
12 \\
12 \\
12 \\
13 \\
13 \\
13\end{array}$ & $\begin{array}{l}2 \frac{1}{2} \\
2 \\
3 \\
2 \\
2 \\
2 \\
2 \\
3 \\
3\end{array}$ & $\mid \begin{array}{c}7 \\
7 \\
\cdots \cdots \\
10 \\
6 \\
\cdots \cdots\end{array}$ & $\begin{array}{l}11 \\
11 \\
20 \\
16 \\
19 \\
16 \\
17 \\
20\end{array}$ & 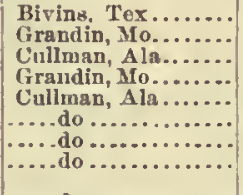 & $\begin{array}{l}\text { Exposure free in opening of forest. } \\
\text { Rocky table-land; opening in forest. } \\
\text { loorder of thicket; freely exposed. } \\
\text { Rocky table-land; partially exposed; in forest. } \\
\text { Exposed; border of woods. } \\
\text { Do. } \\
\text { In midst of thicket; old clearing. } \\
\text { Old pasture, cleared in } 1879 \text {; most vigorous growth; yonng shoot } 19 \\
\text { inclies. }\end{array}$ \\
\hline 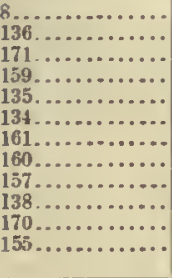 & $\begin{array}{l}15 \\
15 \\
18 \\
19 \\
19 \\
20 \\
19 \\
22 \\
27 \\
24 \\
25 \\
41\end{array}$ & $\begin{array}{l}4 \\
4 \\
4 \\
4 \\
4 \\
6 \\
23 \\
3 \\
61 \\
31 \\
4 \\
11\end{array}$ & \begin{tabular}{c|}
12 \\
10 \\
15 \\
22 \\
10 \\
14 \\
8 \\
12 \\
$12 \frac{1}{2}$ \\
22 \\
15 \\
51
\end{tabular} & $\begin{array}{l}24 \\
20 \\
36 \\
37 \\
20 \\
26 \\
25\} \\
25 \\
25 \\
33 \\
34 \\
70\end{array}$ & 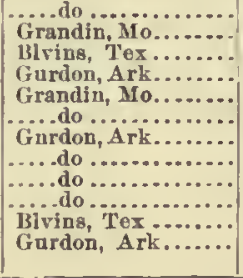 & $\begin{array}{l}\text { Do. } \\
\text { locky hills; open forest. } \\
\text { Opcn furest. } \\
\text { Exposizre free; open grove of second growth. } \\
\text { oppressed in forest opening hy oak scrub. } \\
\text { Rocky; open woods. } \\
\text { Open grove; closely oppressed. } \\
\text { Open grove of second growth. } \\
\text { Do. } \\
\text { Do; } \\
\text { Partially free; in forest. } \\
\text { Free; old fleld. }\end{array}$ \\
\hline
\end{tabular}


TABL.: II.-(irouth of Shortlenf l'ine during stage of rigorous grouth, from fifty to one hundred and twenty years.

\begin{tabular}{|c|c|c|c|c|c|c|c|c|}
\hline \multirow{2}{*}{$\begin{array}{l}\text { Nuniber of } \\
\text { troe. }\end{array}$} & \multirow{2}{*}{$\begin{array}{c}\text { Ringo } \\
\text { lni } \\
\text { atump. }\end{array}$} & \multicolumn{2}{|c|}{ Dlameter- } & \multirow{2}{*}{$\begin{array}{l}\text { Height } \\
\text { to tirat } \\
\text { limb or } \\
\text { crown. }\end{array}$} & \multirow{2}{*}{$\begin{array}{c}\text { Total } \\
\text { helglit. }\end{array}$} & \multirow{2}{*}{$\begin{array}{l}\text { Length } \\
\text { of } \\
\text { timber. }\end{array}$} & \multirow[b]{2}{*}{ I.ocality. } & \multirow[b]{2}{*}{ liemarks. } \\
\hline & & $\begin{array}{l}\text { At } \\
\text { breast } \\
\text { blgh. }\end{array}$ & $\begin{array}{l}\text { Below } \\
\text { crowu. }\end{array}$ & & & & & \\
\hline $169 . \ldots \ldots \ldots . . .$. & 52 & $\begin{array}{c}\text { Inches. } \\
\text { of }\end{array}$ & $\begin{array}{l}\text { Inches. } \\
\ldots \ldots \ldots\end{array}$ & $\begin{array}{l}\text { Heet. } \\
22\end{array}$ & $\begin{array}{l}\text { Feet. } \\
16\end{array}$ & Feet. & Bivluк, Tex........... & Iu forest: snil cold, ublerdralnagf deficlent; cx. \\
\hline $168 \ldots \ldots$. & $\begin{array}{l}58 \\
60\end{array}$ & $13^{64}$ & & $\begin{array}{l}20 \\
45\end{array}$ & $\begin{array}{l}50 \\
81\end{array}$ & & $\begin{array}{l}\text { Baldwin County. Ala., } \\
\text { near'Tensaw lilver. }\end{array}$ & $\begin{array}{l}\text { Exposure free; openlng ln forest. } \\
\text { Coastlluw; loany sand, with Culsan l'ine; exprosiro } \\
\text { fret. }\end{array}$ \\
\hline $167 \ldots \ldots \ldots \ldots$ & 73 & 12 & ......... & 38 & 80 & 32 & Biving, Tex.......... & Opwing In forest; exposure partially free. \\
\hline $165 \ldots \ldots \ldots \ldots \ldots$ & $\begin{array}{l}102 \\
102\end{array}$ & $\begin{array}{l}16\} \\
18\end{array}$ & $\cdots$ & $\frac{60}{45}$ & 94 & $\cdots$ & ......do do & Oppressed. \\
\hline $152 \ldots \ldots \ldots \ldots$ & $\begin{array}{l}102 \\
105\end{array}$ & $\begin{array}{l}19 \\
15\end{array}$ & a........ & $\begin{array}{l}38 \\
82\end{array}$ & 109 & $\begin{array}{l}38 \\
30\end{array}$ & $\begin{array}{l}\text { Gurdon, Ark ............. } \\
\text { Cullman, Ala ........ }\end{array}$ & $\begin{array}{l}\text { Fx posuro free; open forest. } \\
\text { l'artially free on gravelly ridge. }\end{array}$ \\
\hline & 109 & 22 & & 42 & 101 & 40 & .....do & $\begin{array}{l}\text { Exposnre partially free; open forest; dry hill; } \\
\text { sandy, gravelly loam. }\end{array}$ \\
\hline $\begin{array}{l}31 \ldots \ldots \ldots \ldots \ldots \\
168 \ldots \ldots \ldots \ldots\end{array}$ & 111 & 21 & $\cdots$ & 41 & 74 & & 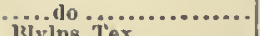 & Ex positre freo; gravelly loam. \\
\hline $160 \ldots \ldots \ldots \ldots \ldots$ & 1116 & 22 & $19 \mathrm{~g}$ & $\begin{array}{l}46 \\
45\end{array}$ & 93 & $\begin{array}{l}46 \\
42\end{array}$ & $\begin{array}{l}\text { Bivins, Tex } \ldots \ldots \ldots \ldots \\
\text { Cnlluan, Ala } \ldots \ldots \ldots .\end{array}$ & $\begin{array}{l}\text { Oppressed on all sidea; red heart alsore } 36 \text { feet. } \\
\text { Exposure free; open forest; rocky, and sandly }\end{array}$ \\
\hline & & & & & & & & loam. \\
\hline
\end{tabular}

TABLE: III.-Grouth of Shorlleaf Pine during stage of slow grouth, latest stage of life.

\begin{tabular}{|c|c|c|c|c|c|c|c|c|}
\hline \multirow[b]{2}{*}{$\begin{array}{l}\text { Number of } \\
\text { of tree. }\end{array}$} & \multirow{2}{*}{$\begin{array}{l}\text { in } \\
\text { gtump. }\end{array}$} & \multicolumn{2}{|c|}{ Dlameter - } & \multirow{2}{*}{$\begin{array}{l}\text { Helght } \\
\text { to first } \\
\text { limb or } \\
\text { crown. }\end{array}$} & \multirow[b]{2}{*}{$\begin{array}{c}\text { Total } \\
\text { height. }\end{array}$} & \multirow{2}{*}{\begin{tabular}{|c|} 
Length \\
of nier- \\
chant- \\
ablo \\
timher.
\end{tabular}} & \multirow[b]{2}{*}{ Localify. } & \multirow[b]{2}{*}{ Rentarks. } \\
\hline & & $\begin{array}{c}\text { At } \\
\text { breast } \\
\text { bigh. }\end{array}$ & $\begin{array}{l}\text { Below } \\
\text { crown. }\end{array}$ & & & & & \\
\hline & 120 & $\begin{array}{c}\text { Inches. } \\
21\end{array}$ & Inches. & Feet. & Feet. & Feet. & Cnlln & Onen forest - hills : goll \\
\hline 150. & 120 & 20 & $\dddot{13}$ & 73 & 110 & 60 & Gurdon, Ark...... & 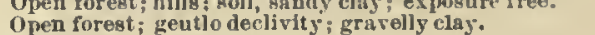 \\
\hline & 120 & 20 & & 47 & 95 & 45 & ..... do.............. & Do. \\
\hline \multirow{2}{*}{$150 a \ldots . . . . .}$. & 132 & 24 & 19 & 47 & 106 & 43 & ..... do ...... & Do. \\
\hline & 132 & 20 & & 42 & 87 & 40 & Cullman, Ala.... & Open forest; clay lill]; exposure free. \\
\hline $129 \ldots \ldots \ldots \ldots$ & 140 & 17 & 12 & 39 & 92 & 38 & Grandin, Mo..... & Exposure free; rock y table-laud. \\
\hline$\ldots . . . .$. & 143 & 25 & 203 & 46 & 117 & 45 & Gurdon, Ark... & Exposuro free; gravelly hlllalde. \\
\hline $128 \ldots \ldots \ldots \ldots$ & 150 & 20 & $\ldots \ldots$ & 50 & 100 & 50 & Grandin, Mo...... & locks table-laud; exposure free. \\
\hline $127 \ldots \ldots \ldots \ldots$ & 174 & 31 & -........ & 46 & 102 & 10 & ....do do............ & Tio. \\
\hline 130 & 180 & 22 & & $\sqrt{2}$ & 91 & 40 & $\cdots \cdots$ & $\begin{array}{l}\text { Rocky table-latud; exposure partially free; allghtly } \\
\text { suppressed. }\end{array}$ \\
\hline $162 \ldots \ldots \ldots \ldots \ldots$ & 195 & 24 & ........ & 37 & 119 & 37 & Birlns, Tex....... & Cold soil : exposnre free. \\
\hline & 204 & 23 & & 61 & 108 & 40 & $\cdots$ & $\begin{array}{l}\text { Coll soil; exposuro free; aflected above } 40 \text { feet witl } \\
\text { redl heart. }\end{array}$ \\
\hline 131. & 218 & 25 & 22 & 55 & 110 & 50 & Grandin, Mo...... & Exposure free; soll loany"; tleej. \\
\hline
\end{tabular}

From the general table (No. IV) and the eorresponding diagram it seems that in the average the tree at twenty is about 30 feet high, reaehes 50 feet at the age of forty, and that its growth in height is in the nain finished at the early age of 70. In keeping with this, the growth in diameter is quite rapid during the first fifty years, eontinues at a moderate paee up to 80 , when the age of slow growth is entered. 
RATE OF GROWTH OF SHORTLEAF PINE.

TABLS IV.-Rate of growth of Shortleaf I'ine.

\begin{tabular}{|c|c|c|c|c|c|c|c|c|c|c|c|c|}
\hline \multirow[b]{2}{*}{ Age. } & \multirow[b]{2}{*}{$\begin{array}{c}\text { Diameter } \\
\text { with bark } \\
\text { (breast } \\
\text { high). }\end{array}$} & \multirow{2}{*}{$\begin{array}{c}\text { Leagth } \\
\text { of log } \\
\text { with nul- } \\
\text { per diam- } \\
\text { eter of } 5 \\
\text { inches. }\end{array}$} & \multirow[b]{2}{*}{$\begin{array}{l}\text { Total } \\
\text { height of } \\
\text { tree. }\end{array}$} & \multicolumn{2}{|c|}{ Volume. } & \multicolumn{5}{|c|}{ P'eriudical grow th by decales. } & \multirow[b]{2}{*}{$\begin{array}{l}\text { Average } \\
\text { annual } \\
\text { accretion. }\end{array}$} & \multirow[b]{2}{*}{$\begin{array}{l}\text { Current } \\
\text { accretion. }\end{array}$} \\
\hline & & & & Treo. & $\begin{array}{l}\text { Log up to } \\
5 \text { inclies } \\
\text { diam- } \\
\text { etcr. }\end{array}$ & Decade. & $\begin{array}{l}\text { Jiam- } \\
\text { eter. }\end{array}$ & Height. & $\begin{array}{c}\text { Area of } \\
\text { cross } \\
\text { section. }\end{array}$ & Volume. & & \\
\hline 10 & $\begin{array}{r}\text { Inches. } \\
\text { 3. }\end{array}$ & Feet. & Feet. & $\begin{array}{c}C u, f t . \\
v, 32\end{array}$ & $C u, f t$. & Fir & $\begin{array}{l}\text { Inches: } \\
2.2\end{array}$ & Feet. & $\begin{array}{c}\text { Niq. ft. } \\
\text { u. } 03\end{array}$ & $\begin{array}{ll}C u \cdot f t . \\
\text { u. j2 }\end{array}$ & $\begin{array}{l}C u, f t . \\
0.03\end{array}$ & $\begin{array}{l}\text { Cu. ft. } \\
\text { o. }\end{array}$ \\
\hline 20 & $\begin{array}{l}5.2 \\
7.4\end{array}$ & 15 & 27 & $\frac{2.21}{7.55}$ & 6,37 & Second.... & 2.3 & 16 & .07 & 1. 89 & .11 & .19 \\
\hline 80 & 9.3 & 26 & 51 & 14.06 & 12.98 & Fourth & $\vec{i}$. & 10 & .13 & & .25 & $\begin{array}{l}.53 \\
.65\end{array}$ \\
\hline 50 & 11 & 38 & 60 & 22.18 & 21 & Fif & 1. & 9 & .17 & & .44 & .81 \\
\hline 60 & & $4 x$ & 67 & 31. & 31 & sixtll .... & 1. & 7 & .21 & 9 & 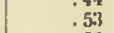 & .08 \\
\hline io & 14 & 56 & 7) & 43 & $4: 3$ & $i t b$ & 1. & 4 & .21 & 11 & .62 & 1. 20 \\
\hline 80 & 16 & 61 & 75 & 56 & 55. & Eig & 1. & 4 & .23 & 12 & .70 & 1. 26 \\
\hline 90 & 16.5 & 64 & 78 & 62.53 & 61.8 & Niuth. & .6 & 3 & .1 & & .69 & .60 \\
\hline 10 & 17.0 & 67 & 81 & 67.68 & 67.05 & Tenth & .5 & 3 & .07 & 5.15 & .68 & \\
\hline
\end{tabular}

\section{HEIGHT}

\section{IN FEET.}



F19. 11.-Growth of Sbortleaf Pinc: Heiglit, diameter, and tubjic cuntents of average trees at 10, 20, etc., years of age.

\section{CONDI'IONS OF HEVELOPMEN'T'.}

Soil cul climate.-The Shortleaf Pine prefors a well-drained, light saudy or gravelly elay soil or warm loam, even if defieient in the elements of plant food. Soils of this charaeter which are fond widely prevailing over the undulating or broken uplands, if only of sufficient deptlr, will produce this tree in greatest perfection. It avoids the strongly caleareous and the rieh alluvial soils, as well as purely silicious, being dependent on the presence of a certain amount of elay by which the mechanieal eondition of the soil is improved, rendering it more eompact and more 
retentive of moisture. That a purely sandy and highly porous soil is not favorable to this tree is shown by the stunted growth of the waifs sometimes fond in the openings of the forests of Lougleaf' line on the sandy, arid uplands in the lower part of the eoast pine belt.

Distributed in its range over $\mathbf{1 0}$ degrees of latitude and exposed to wide differences of temperature, it slows almost the sane thrift of growtl near its northern limits under the isotherm of $50^{\circ} \mathrm{F}$., and in regions where the thermometer falls to near $20^{\circ}$ below zero, as in lower latitndes witl a mean annual temperature of $64^{\circ} \mathrm{F}$. It can, theretore, cudure a considerable range of temperature.

The conditions of atmospherie moisture evidently exereise a inncli more deeided inflnence over its distribution, and, without doubt, "pon its individual development. The tree is found in greatest abnndance and of best growtl where, within the limits of its distribntion, the annual lainfall varies between 48 to 52 inches, it is less frequent in the distriets where the precipitation cxceels 56 inehes, still scareer where the anuual rainfall averages below 44 inelies, and entirely wanting where this is less than 40 inehes. Hence it is found best developed in the npper part of the Gnlf States and west of the Mississippi River in adjacent northern districts from the interior of Georgia to northeastern Texas, where the most favorable eonditions in regard to atınosplierie preeipitation prevail. The tree seems to avoid the humid air of the eoast along the Gulf, as well as along the seashore of the Sonthern Atlantie States, nor does it aseend the monntains in these States above an altitude of 2,500 feet.

\section{RELATION TO LIGHT AND ASSOCIATED SPECIES.}

The Shortleaf Pine, like most pines, is a light-needing speeies, being, however, less sensitive to. a deficiency in this direction than the Longleaf and Cuban pines, which latter sueeumb in eompetition with the Shortleaf Pine. Originally the Shortleaf Pine is fonnd more or less assoeiated with various oaks (Spanish Oak, Blackjaek, Scarlet Oak, Post Oak, and Black Oak), the Mockermut and the Pignnt Hickory, and morc rarely with the Chestnnt, the Mountain Oak, and the Serub Pine. All of these speeies prefer the warm, lighter soils of the uplands. These companions of the Shortleaf Pine are joined in the lower Sonthern States by the Loblolly and Isongleaf Pine. Wherever in these upland forests an opening is made the Shortleaf Pine gains over its associates, fiuding its only sueessfnl rival in the Loblolly Pinc. It is in the Sonthern States proverbial that in the upland forests "the pine is erowding out the hard-wood timber," a faet early observel. The displaeement is effeeted either gradually in the eonrse of time, or instantly when the renoval of the original timber growth has been sudden. In the upper part of the maritime pine belt, where it is associated with the Longleaf Pine, the latter is sure to be replaced by the Shortleaf speeies, often joined in the eourse of such invasion by the Loblolly Pine.

\section{ENEMIES.}

Little is known of the fungoid parasites and of the insects endangering the life of the Shortleaf l'inc. From my own observation, it seems that this tree is less aftecter by the former than the other pines of the same region. In the lumbering distriets of Alabama a discase called redheart or redrot, cansed by the mycelinu of a large species of Polyporns, whieh is so highly destructive to the Longleaf Pine, is in this speeies almost nuknown. In northeastem Texas this disease was found to affect the supcramnated timber trees, which were over two hnndred years old. A ceorling to A. S. Packard' the hosts of insects affeeting this pine serionsly are seatreely less in number than those infesting the Longleat Pine; its enemies belong to the same or very nearly related kinds. Among the borers the Monshaminus confusor and other species of the same genns dig burrows in the timber to the heart; the larvie of numerous Buprestide, Cerambycide, and Curculionide burrow under the bark, and the Tomicus calligraphus, cacographus, colatus, and other species of Scolytide, at certain seasons are in immense numbers carrying on their work of destrution in the cunbinm layer, leaving in wonderfnl delineation on the inside of the bark the marks of their pernieions activity and eansing the speedy death of the tree.

Mr. 1\%. A. Seluwar\%, of the Division of Entomology, 1)epartment of Agrienlture, remarks in this enmection that of more than nsual interest is the remarkable aud disastrons invasion of one of 
these bark-boriug Scolytid beetles (Dendroctonus frontalis), whieh in former years was universally cousidered a rare species. This invasion started in 1858 from the mountainons regions of West Virginia aud within fonr years spread thronghont the Alleghany Mountaius and adjacent lowlands from Pennsylvania to the Carolinas. The amonnt of damage caused by this beetle within that time to the Shortleaf Pine and other pine trees has been enormous. A eontagions disease, probably of a fungoid eharaeter, terminated in $\mathbf{1 8 9 2}$ this invasion just as suddenly as it had commenced, and in 1893 not i single living beetle eould be found throughout the infested region. The white froth licling the larva of a tree jumper (Aphrophora parallela) is very eommon on the summits of the twigs, the larve of the sawflies are seen at the same season to feed on the tender, young foliage, which is also infested by a small white Gelechia depositing its eggs on the leaves, the larva boring into them to provide shelter for their pupse; and aceording to Mr. Schwarz the leaves of the Shortleaf Pine are frequently found completely covered by a seale insect (Mytiinspis pinifolice), eausing what is termed in New England the "white malady" of the pine. Of the flat-hearled borers, larva of the Buprestide, the most injurious species are Ohrysobothris dentipes (Germ.), Chalcophora virginiensis (Drury); less common, Chalcophora georgiana (Lec.) and Buprestis lineata Fab.

lixposed to the same dangers of destruetion by forest fires and by live stock of every kind, which threaten the Longleaf species with extermination, the chunces of this pine to resist them and to escape sueh eventually are more favorable in consequence of the greater facilities for its reproduction and of its rapidity of growth during the earliest stages of its existence.

The pernicions influences of the first of these ageneies is, however, painfully visible near the settlements where the forest is exposed to its effects oue season after another. In sueh loealities the pines are of stunted growth; in the middle stage-their very prime of life-they exhibit signs of deeay and early death. But few of the younger trees exposed to fire were found on elose examination to be free from defects and marks of inpending disease.

Confined to the gentle slopes of the low hill country, to rolling uplands, and to broad table-lands, this tree is scarcely exposed to destruetion by torrents and Hoods. Unsought for its resinous juices, it is not subjeeted to the wholesale destruction eansed by the prevalent methods employed in the manufacture of naval stores. No other timber tree found in the southern portion of the Atlantic forest regiou is more easy of natural reprodnetion than this species throughout the wide range of its distribution. This is readily aceounted for by its great feeundity, the seeds prodnced in great abundanee almost without failure every year being profnsely spread far and wide, and gerninating easily wherever the proper soil aud a chance is offered for their reception. By their thrifty growth the seedlings soon gain the upper hand over the eontemporary growth of other species.

Thronghont the interior of the $\Lambda$ tlantic and the Gulf States tracts of upland, originally eovered with fine oak forests, which had been cleared for enltivation and but little over half a century ago abandoned, are found at present oeeupied by the Shortleaf Pine, forming dense groves of trees (i5) feet and over in height, witli a diameter of 10 to 12 inehes, standing 18 to 20 feet apart, witl no undergrowth whatever. ${ }^{1}$ Such young forests, met with in every stage of growth, affori highly instruetive lessons of the ways taken by nature in the spontaneous restoration of the forest. In such spontaneous growths of the Shortleaf Pine the saplings form from the first mostly dense thickets. Before having arrived at their tenth year the work of thiuning has actively begun by the death and speedy dceay of the weakest. Thus favored by the aceess of light and air, the surviving trees shoot rapidly upward, the most aspiring individuals spreading out their crown, overshadowing those lagging behind, whieh being thus eut off from the infuences above all others reyuired for their existenee, one after another die. Before the trees have reached the middle stage of their growth the stand of timber in the young forest appears to be firmly established, and during the following period, embraeing less than halt a century, they lave attained the fullness of their growth, furnishing timber fully matured and of the dimensions and quality reupired by the present standard. Uneliecked by destruetive influences the rotation of a crop of timber of the Shortleaf l'ine prodneed without the interference or assistance of man, can be said to be aceomplished within a periud of from eighty-five to ninety-five years.

'Charles Mohr: Proceedings of the Fourth Annual Meeting of the American Forestry Congress, Boston, September, 1885 . 


\section{FOREST MANAGEMENT.}

From the plaee this species is taking among the seeond grow th it can be safely predicted that it is destined to be the timber tree of the future, as fill as the Southern States of the $\Lambda$ thintie forest region north of the Longleaf Pine belt are concerned. It is npon this tree that in this section suceedling generations will have to depend for their supplies of pine timber of superior quality, and in which the nearest substitute is to be fonnd for the supplies furnisled at present by the longleaf Pine. That the resourees of the latter under the increasing strain to whieh it is subjeeted will be completely exhausted before its restoration can be effected is too evident to admit of any loubt.

Among the timber trees of the coniferons order found in the Atlantic forests, there is, then, searcely a species presenting stronger elaims to the attention of the forester than the Shortleaf l'ine. $A$ s far as its demands upon climate and soil are eoncerned, it is cupable of successfully establishing itself over the immense territory reaehing from $30^{\circ}$ to $38^{\circ}$ north latitude and fiom the $\Delta$ tlantic Slope to the treeless plains of the West; embracing within these limits areas of wide extent, with all the eonditions reqnired for the best development of this speeies, and in great measire adapted to nothing better than the growth of timber. Of not less importance than its value as a timber tree are its faeilities for natural renewal, resulting from the abundant crops of seed produced almost without failure every year and its aggressive belavior toward couneting speeies in the sueeessfinl struggle for the possession of the soil.

From a closer observation ot the young forests of spontaneous growth at different stages, it is apparent that in the establishment and rearing of al forest of Shortleaf Pine, where mother tiees exist, nature reqnires eomparatively little assistance from the hands of the forester, and that the efforts of the latter will be ehiefly eonfined to measures of proteetion against destruction by fire and against the injuries eansed by inroads of live stoek during the earlier stages of growth. That by thimning out, praetieed after the first to the middle or end of the third decade, the forest growth would be benefited, there ean be but little doubt. To what extent, by such interference, the production of merehantable timber ean be promoted and in quantity and quality improved at the least eost remains a matter of future experiment. In the total absenee of faets, based on experiment, no snggestions ean be offered on these points other than sueh as ean be dedueed from the natural reqnirements of this speeies, as already discussed.

In conelusion, it ean be safely asserted that the Shortleaf Pine is destined to take a prominent plaee in the forest management of the future thronghont the regions fivorable to its growth, uot only on aeeount of its eeonomic value in the natmral forest, but also in holding out better prospects to the forest planter for the produetion of timber of higher quality in the shortest time than any tree of the same order in the Southern Atlantie forest region. That the methods of a rational forest management will have to be resorted to at no distulit time can witl eertainty he predieted, although the timber wealth existing at present in the vast territory of its growth may appear enormous.

Of great inportanee in the reforestation of large areas, this tree is of no less signifieance to the farmer who is aware of the advantages resulting from the restoration of the tree-covering on his denuded uplands, either originally unfit for profitable tillage or thrown out of cultivation after their exhaustion. By the faeility of its natural renewal the Shortleaf Pine affords within a short tine a firm protection to the light soil, preventing it from being earried away by wind and rain, providing al shelter for the erops and for insectivorous birds, a lasting incone of increasing supplies of timber and finel on linds that yield no other profit whatever, and to the lands abandoned after their exhaustion a chanee for their reeuperation while resting under the eover of its shade. 


\title{
ADDITIONAL NOTES ON SHORTLEAF PINE.
}

\author{
By Filibert Roth.
}

(September 1, 1897.)

As might be expeeted from its wide and extremely irregular distribution, this tree reeeives many uames and in many loealities is little or not known even to otherwise quite well-informed woolmen. Thus in an entire eounty of Sonth Carolina, where the tree oeeurs but sparsely, not a single man was met who reeognized this speeies. Among the many appellations the name "Rosemary" deserves mention, having wille and varied applieation and having led to eonsiderable controversy and mueh eonfusion. Apparently this name originated in the North Carolina ${ }^{1}$ pinery, $^{2}$ where even to-day this tree, though by no means abundant, is well known to all woodmen. In the eountry about the Albemarle and Pamlieo sonnds all woodnen interviewed invariably knew it and eonsistently ealled it Rosemary Pine. In the towns and by manufaetnrers in this distriet and also in the eoast pine belt farther south the tree is generally not known at all, but the word "Rosemary" is nevertheless in eommon use, and Rosemary Pine timber held in espeeial regard. Questioning inany of the experieneed manufaeturers, it was fonnd that Rosemary Pine in the market towns refers not to a partieular speeies but to large seleet fine-grained timbers of any pine exeejt Longleaf, and was formerly a much-desired artiele for ship planking, ete., being less resinons, softer, and claimerl to be less prone to shrink and swell than the wood of Longleaf Pine.

As mentioned in the monograph, Shortleaf Pine oeeurs only seatteringly in the great pinery of North Carolina and southeru Virginia, and forms probably not as muel as 1 per eent of the total ent of the North Carolina pine on the market. In Texas, where this species is generally ealled Shortleaf Pine, it was seen as far west as Houston, mingling in sinall quantities and small sizes with the Loblolly. Going in a northeastern direetion, it beeomes more and more abundant, being the predominant tree east of the Neehes River and north of the Longleaf Pine distriet.

The Shortleaf l'ine remains generally undersized in the coast pine belts, where fair-sized speeimens are rarely met. In its proper home, in eastern Texas and Arkansas, it attains fair dimensions, generally 70 to 90 feet high and less than 30 inehes diameter. Its growth, though oeeasionally quite rapid, seems usually much slower than that of Loblolly, a faet especially true of the regions where it is most abundant. In lıundreds of groves the leaders of small saplings were found eommonly less than 12 inehes long, thus remaining much behind the other Southern pines in this respeet. More even than Loblolly, the Shortleaf requires a close stand to induee cleaning of limbs.

The phenomenon of sprouting was well illustrated all along the Houston, Last and West Texas and also the St. Lonis, Iron Mountain and Southern railways as far north as Iron Monntain, Mo., where hundreds of acres of the right of way were eovered with the bushy elusters of vigorous spronts, 10 to 30 from one stump.

Like Pond Pine, the Shortleaf is sometimes bled for turpentine. One tree was seen with two boxes which had been worked for at least ten years and then abandoned, and two new boxes workerl for the seeond season this year (1897).

Probalbly suggested by tho small rosemary bead-like cones clustered in great abundance on old trees. 




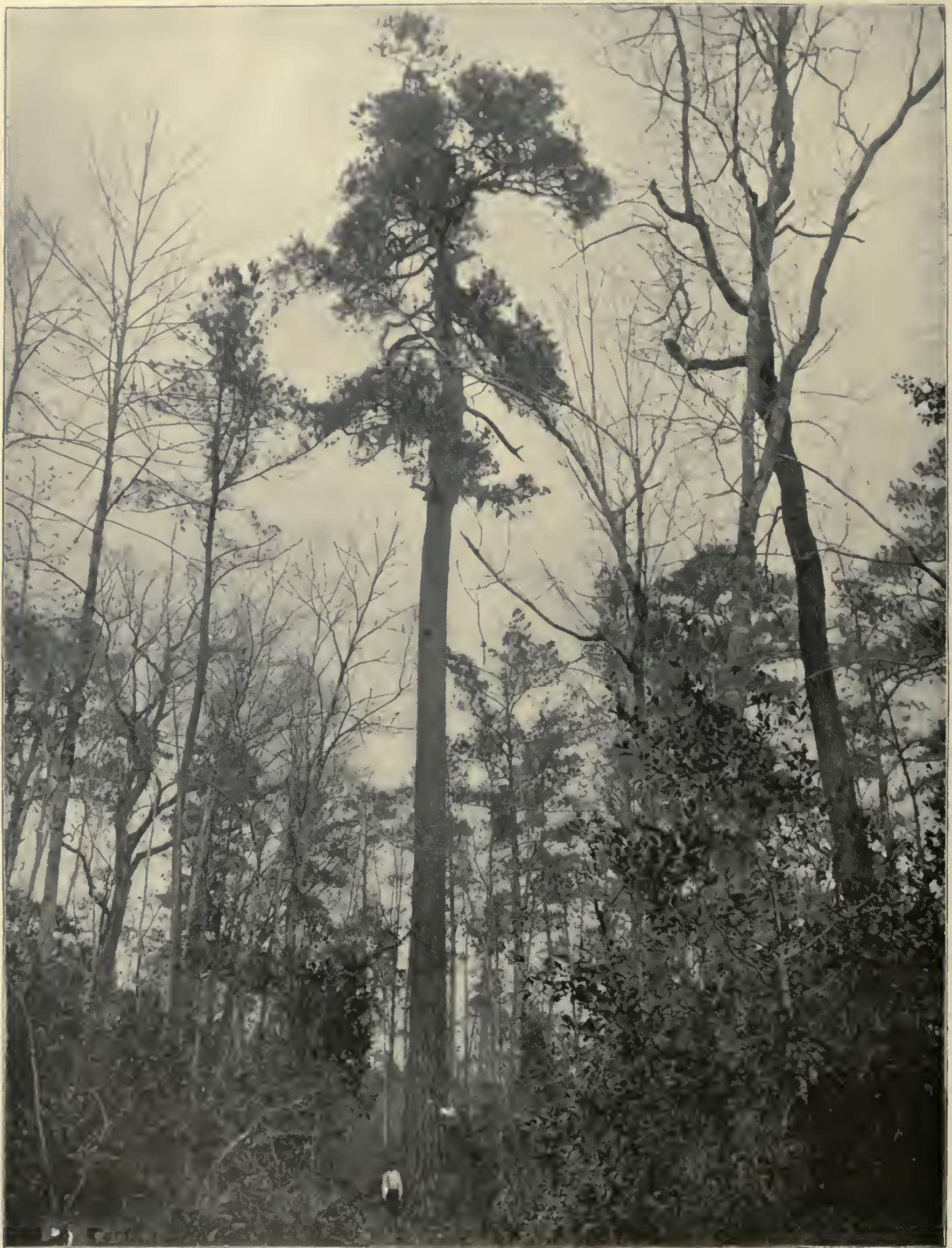




\section{THE LOBLOLLY PINE.}

(PINUS TADA Linn.)

History and Distribution.

Pronucts.

Botanical Descirtption.

DESCRIPTION OF WOOD.

PROGRESS OF DEVELOPMENT.

Conditons of DEVELOPMENT.

Reproduction.

anditional Notes on loblolly Pine.

7092-No. $13-8$ 


\title{
THE LOBLOLLY PINE.
}

\author{
(Pinus toda Linn.)
}

Syuonyms: Pinns Tada Linneus, Spec. Pl., ed. 1, i, 1000, excl. habitat "Canadce paludosis" (1753). Pinus Tuda a tenuifolia Aiton, 1. Lort. Kew., ed. 1, iii, 368 (1789).

Pinus Tuda Rifinesque, Flor. Ludovic., 162 (1817), nomen undum.

COMMON OR LOCAL NAMES.

Loblolly I'ine (Del., Va., N. C., S. C., Ga., Ala., Fla., Miss., La., Tex., Ark.).

Oldfeld l'ine (Del., Va., N. C., S. C., Ga., Ala., Fla., Miss., La., Tex., Ark.).

Torch Pine (ling. lit.).

Rosenary Pine (Va., N. C.).

Slash Pine (Va., N. C., in part).

Long Schat Pine (Del.).

Long Shucks (Md., Va.).

Black Slash Pine (S. C.).

Frankiucense l’ine (lit.).

Shortleaf Pine (Va., N. C., S. C., La.).

Bull Piue (Tex. and Gulf region).

114
Virginia l'ine.

Sap l'ine (Va., N. C.).

Moadow Pine (Fla.).

Cornstalk l'ine (Va.).

Black Pine (Va.).

Foxtail line (Va., Mll.).

Indian Pine (Va., N. C.).

Spruce Pine (Va., in part).

Bastard l'ino (Va., N. C.).

Yellow Pine (N. Ala., N. C.)

Swamp Pine (Va., N. C.).

Longstraw Pine (Va., N. C., in part). 


\title{
THE LOBLOLLY PINE.
}

\author{
By Charles Mohr, Ph. D.
}

INTRODUCTION.

Among the trees remarkable for the part they take in the spontaneous renewal of the forests in the Southern Atlantic region after the destructive interference by man, the Loblolly Pine is most prominent. This readiness to oecupy the ground lends to it a special economic significance in forest growth, aside from its value as a source of timber and as an abundant source of fuel. There can be 110 doubt that in the future management of the forests of the lower Southern States the Loblolly Pine will be assigned a highly important place. This view is confirmed by the fact that in the older of the States within the limits of its distribution, where the original timber growth lias suffered greatest reduction, as in North Carolina, the second growtl of this tree is largely depended upon to furnish the timber supply for the existing lumbering industry.

Although known to lave contributed to the necessities of the earliest settlers of these coasts, aurl forming at present a large part of the lumber supplies reaching the markets cast and west of the Mississippi River, the merits of the Loblolly Pine and its economic bearings are generally but little understood, wide differences of opinion about its value as a timber tree prevailing. Such diversity of opinion is in itself a sufficient reason for a fuller investigation of its life history.

In the preparation of this monograph the writings of F. A. Michaux ${ }^{1}$ and Rev. M. A. Curtis ${ }^{2}$ and the report of the Tentl Census ${ }^{3}$ lıve been consulted. To Prof. Lester Ward and Mr. Canby thanks are due for valuable information on the distribution of the Loblolly Pine toward its nortlicrn linits. Mnch information of practical value was elicited by the Division of Forestry from numerons manufacturers of and dealers in lumber in the lower part of Virginia and in North Carolina, which has bcen largely quoted.

\section{HISTORICAL.}

The Loblolly Pinc was recognized as a timber tree of value by the earliest settlers of lower Virginia and Nortl Carolina. Its timber was largely used in the construction of their dwellings. Michaux states that three fourths of the houses in lower. Virginia were built of Loblolly Pine, aud that its mighty trunks, furuishing shafts of clear timber of largest size, werc in carly days held in ligh esteem for masts by the navies of the world. The distiuctive characters of the tree were clearly understoon by the earliest writers on North Annerican botauy. F. A. Michaux defined the northern limits of the tree and its distribution in the sonthern $\Lambda$ tlantic States, and first pointed to its economic value. The Rev. M. A. Curtis gives an account of its distribution in Nortl Carolina and recognized the form distinguished in that State as Slash Pine or Rosemary Pine. Investigations of the forest growth by the writer, under the direction of Prof. Charles S. Sargent, for the Tentlı Census, and later iuvestigations made in the transuississippi region, under the direction of the Division of Forestry, have led to a more accurate knowledge of the

${ }^{1}$ Michanx, F. A. The North American Silva. Philadelphia, 1856.

${ }^{2}$ Cartis, M. A. The Timber Trees of North Carolina. Geol, and Natural History Survey of North Carolina. Part III, Hotany. Raleigh, 1860.

${ }^{3}$ Volume 9 of the Tenth Census. Charles S. Sargent. 
distribntion of this tree in the Southwestern States, to the establishment of its western and northern boundary lines, aind to a more general appreciation of its ceonomic importance in its eastern and western l'ange.

GHOGRAPHICAL DISTRIBUTION AND ECONOMIO HISTORY.

The loblobly P'ne extends from the Delaware and Maryland peninsula through lower Virginia to Cape Malabar, in Florila, and all over the Gulf States and southeru Arkansas to the Coloralo River in Texas (see Pl. XVIII). The northern linit of the Loblolly Pine ean be deseriber ly a line drawn from the lower part of Neweastle Connty, Del., throngl the District of Colmubia, toPetersburg, Va., thcuee toward middle North Carolina, following in its western eonrse nearly the thirty fifth degree of north latitude to the sonthern boundary of Tennessee, throngh southern Arkansas to the sontheasteru eonfues of the Indian Territory. Its most western station is an isolated traet of small extent near Bastrop, Tex., the sole and last representative of the Atlantic pires in the Southwest.

Miehanx the younger establisherl the northern limit of the Loblolly Pine near Fredericksbnrg, Va., between the Rappalıannoek and Potomac rivers; M. A. Curtis plaeed it in or close to the District of Columbia. Its oeeurrence in the District was, however, considered donbtful, or merely accidental, until in 1885 it was eonfirmed by Dr. George Vasey, who discoverel a group of fullgrown trees in the woods near the Reform Sehool. Mr. Willian Cauby states that he "fomnd in the lower part of Neweastle County, Del., a good many Loblolly Pines, and from the point mentioned it beeomes more and more plentifnl and widespread in the Delaware-Haryland peninsula."

On the Atlantic Slope, near its northern limit, the Loblolly Pine oeenrs most fieqnently in the flat lands of the tidewater districts, forming rarely continuons forests, more frequently less compact bodies of timber, assoeiated with the Shortleaf Pine, oalis, and other hard-wood trecs.

In Virginia this tree is not found beyond the northeru limit of the Tertiary strata of the coast region, and is not unct with west of Petersbnrg and lichnond.

In the lower part of this State, as in North Carolina, the Loblolly Pine was formerly found in great perfection and abundance-broad forest belts of Loblolly alternating with forests of Shortleaf in Miehaux's time. 'The original forests have, however, iı a great measure disappeared, and their progreny, of seeond or third growth, is now depender npon as the prineipal sonrce of lnmber. On the lands exhansted by the enrlier planters, and which have been abandoned for several generations, the timber of this Sap Pine, or Oldfield l'inc, has in many localities attained dimensions and a degree of maturity fitting it for all purposes for which timber of the original growth is cunloyed. This important faet is confirmed by parties engaged in the lnmber business in southeastern Virginia and in eastern North Carolina.

From information reeeived it is evident that in these parts the seeond growth of Lohlolly Pine is chiefly depended upon for the manufaeture of lumber, and it is now ascertained that the Shortleaf l'ine eontributes but a small part of the timber supply. Both of these trees ane known by the inlubitants as Shortleaf, or Shortstraw, Pine, and their timber is sawn indiseriminately; the proportions of the Inmber of either reaching the markets ean therefore not be determinerl. Mlr. Joseph Allard, jr., of Richmond, reports that most of the Virginia Pine is Loblolly Pine, and that every fifty years will produce trees large enongh for sawlogs, three to each tree, averaging 16 feet in lengtlı. Mr. Sparrow, of Brooke, Stafford Connty, states that the pine of this eounty, and in Caroline Connty, is alnost cntircly of the Oldfield Pino (Loblolly l'inc), and that in the latter from thirty to forty sawmills are entting this pine. Messrs. J. L. and Edward Rogers, from Suffolk Connty, eaels remark that "large quantities of lumber are manufactured from Oldfield l'ine, which is fust taking the plaee of Yellow Pine (Pinus echinata), the latter laving becn used up by the sawmills in this section." The young timber is, accorling to the sane aceomnts, cut into joists, uprights, and other square stuff for framing; the best quality is selected for flooring, ceiling, and other inside finish, the lumber being sold nuler the name of Virginia Pine in the markets of Washington, Baltinore, and Philatlelphia.

On the coast of sonthern Virginia the Loblolly Pine forms abont 75 per cent of the timber standing. According to all aceounts the original growth is rapidly disappearing, but the exceed- 


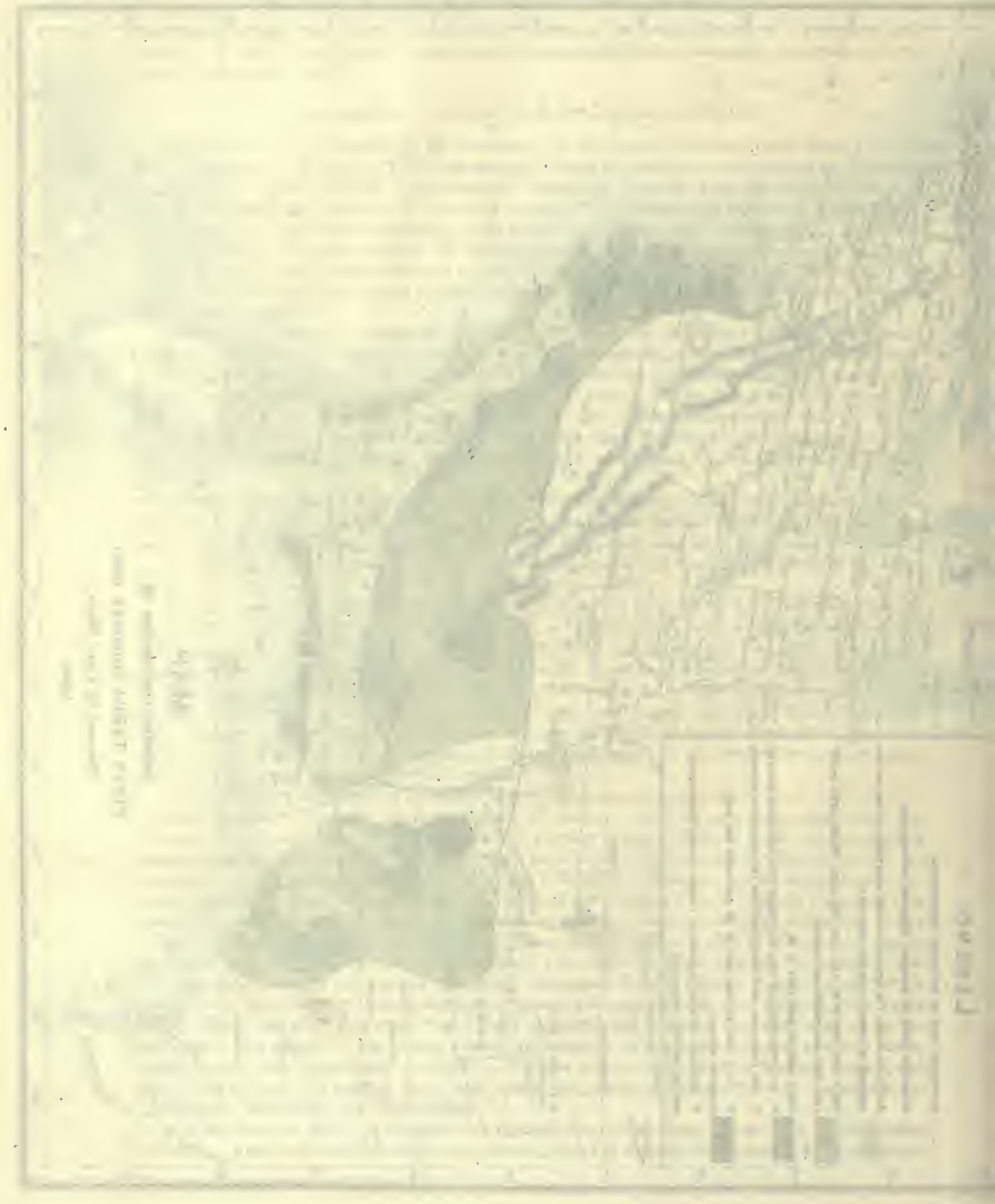


ingly large area of exhausted lands abandoned in that seetion by the cultivators during a long period of time has been taken entire possession of by this tree.

In North Carolina the Loblolly is the predominating tree throughout the eastern coast plain and in the lower part of the State, where it forms extensive forests, nore or less frequently interspersed with Longleaf Pine. Sonth of Cape Fear River, however, the latter prevails alınost exclusively. In the extensice region watered by numerous streams flowing into Albemarle and Pamlieo sounds, in the rich, moist soil of the wide swamps above tide watcr, the Loblolly reaches its best development, attaining dimensions which place this trec among the timber trees of first order. The primeval forests of this pine lave, however, almost eompletcly disappeared in this regirn, and with them the gigantie trees of this speeies known in the market as Rosemary Pine, onee so highly prized and eagerly sought in shipbuilding. Fartler south, in the low pine barrens, this tree is largely superseded by the Longleaf Pine, and is principally eonfined to the borders of the swamps and to the bottoms along the water courses. Throughout the lower part of the eoast pinc belt, after the removal of the original timber growtl, the progeny of the Loblolly Pine immediately takes possession of every opening, and partieularly of the fields thrown out of eultivation.

"The prineipal kinds of Loblolly recognized by the lumbermen under distinct names are:

"1. Rosemary Pine, the best kind froun the trees of best development, of a fine grain but heavy, hard, durable, with but a small proportion of sapwood. At present scareely known by name at the mills in the section where half a century ago it abounded.

"2. Swamp or Slash Pine, of a coarser grain, with about one-half of the diameter of the tree in sapwood. This kind comprises most of the timber of original growth, and the oldest and best matured seeond growth.

"3. Oldfield Pine, by the rapidity of its growth, is very coarse-graincd and for the greater part sap, seareely one-fourth of the dianneter being heart. At present the prineipal source of the timber supplies in the eoast region."

At the sawmills at Goldsboro, close to the border of the Longleaf Pine region, over 50 per eent of the lumber sawn is Loblolly Pine. On a trip through the forests between the Neuse and Trent rivers it was observed that the Loblolly Pine forms over two-thirds of the tree eovering, almost entirely of seeond growth, of dimensions to furnish sawlogs of from 10 to 18 inches mean diameter by a length of from 15 to 30 feet. The sandy swells and knolls rising above the flats originally eovered with the Longleaf Pine are not infrequently oceupied by a young growth of Loblolly. The mills at Newbern and vicinity are almost solcly depending for thcir lumber supplies upon these forests of second growth. The same eonditions are prevailing in Duplin and in Pender County, by the reports of operators. Mr. C. C. Willians, at Teacheys, in Duplin County, states that 66 per eent of the timber sawn is Loblolly Pinc, mostly of serond growth, furnishing timber for creosoting and lumber for building purposes.

Mr. Bauman, at Burgaw, reports that the Oldfield Pine (Loblolly of second growth) is coming more and more into use every year, and the demand for this kind of lumber is greatly inereasing. In a number of the Newbern journals of 1891 it is stated that over $60,000,000$ feet of lumber, boarl measure, were produeed in $1891 \mathrm{ky}$ the inills of that place and the vieinity. In the bulletin quoted the ontput of the nine mills in operation during 1893 is given at $38,000,000$ feet, board measure. The timber delivered at the mills sells for about $\$ 5$ per 1,000 feet, and the price of rough lumber averages $\$ 12$.

In the latest report on tive forests of North Curolina the acreage of the Loblolly Pine, including the land covered with the second growth, and where the Loblolly Pine is taking the place of the Longleaf l'ine, is stated as exeeding 4,000,000 acres. The standing merchantable timber can be said to cover 1,150,000 acres. Allowing 4,000 feet, board measure, to the acre, this will inake $4,600,(000,000$ feet of standing Loblolly Pine in 1893. The total cut of Loblolly Pine for the same year has been reported at $290,000,000$ fect, board measure. ${ }^{2}$

In South Carolina and Georgia the Loblolly P'ine is eonfined all over the eoast pine belt to the more or less swanpy borders of the pine barrens scattered among the broad-leaf evergreens and

'The Forests, Forest Lands, and Forest I'roducts of Eastern North Carolina. W. W. Ashe, p. 41, Bull.5, N. C. Geol. Snrvey.

${ }^{2}$ W. W. Ashe, Bulletin No. 5, Nortlı Carolina (ieol. Survey, Raleigh, 1894, p.41. 
decidnons trees peculiar to these latitndes-the Magnolia, Sweet and Red Bay, Blaek Gum, aud 'Iiti, associated with the Cuban Pine. The timber of the Ioblolly Pine prodnced in these swamps is of good gluality, but with the sapwood from 4 to 5 inches on a radius of from 8 to 12 iuches. It has been noticed that among the original tree-covering Loblolly Pines above 2 feet in dinmeter were frequently fonmd affected with dry or red rot.

On the dry rolling pine mplands of these States to the foot of the montain ranges, rising to an elevation of 800 to 1,000 feet above sea level, as well as of the Gnlf States east of the Mississippi, this pine is found more or less dispersed among the hard-wool timber, bnt is eonsidered of no value except for fnel; the trees branch a short distanee above the gronnd and the timber is too knotty to. be fit for lumber.

Five trees from the damp, flat pine barrens bordering upon the swamps, felled for test logs in Hampton Connty, S. C., showed the following dimensions:

Measurements of fire trees.

\begin{tabular}{|c|c|c|c|c|c|}
\hline $\begin{array}{l}\text { Number of } \\
\text { rlngs on } \\
\text { gtump. }\end{array}$ & $\begin{array}{l}\text { Hiameter } \\
\text { at breast } \\
\text { liigh. }\end{array}$ & $\begin{array}{l}\text { lleight } \\
\text { of trie. }\end{array}$ & $\begin{array}{l}\text { Length of } \\
\text { timber. }\end{array}$ & $\begin{array}{l}\text { Diametior } \\
\text { below } \\
\text { erown. }\end{array}$ & $\begin{array}{l}\text { Sapwood } \\
\text { on rarlins } \\
\text { of butt. }\end{array}$ \\
\hline $\begin{array}{r}103 \\
103 \\
80 \\
05 \\
63\end{array}$ & $\begin{array}{r}\text { Inches. } \\
26 \\
22 \\
17 \\
19 \\
14\end{array}$ & $\begin{array}{r}\text { Feet. } \\
118 \\
118 \\
103 \\
112 \\
90\end{array}$ & $\begin{array}{r}\text { Feet. } \\
55 \\
70 \\
66 \\
53 \\
54\end{array}$ & $\begin{array}{r}\text { Inches. } \\
17 \\
14 \\
13 \\
14 \\
9\end{array}$ & $\begin{array}{r}\text { Inches. } \\
51 \\
4 \\
31 \\
3 \\
3\end{array}$ \\
\hline
\end{tabular}

In peninsular Florida the Ioblolly Pine is more rarely found, its plaee in the old fields being taken either by Cuban Pine or Longleaf Pine.

In the eastern Gulf States thronghont the eoast pine belt the Loblolly Pine is seattered along the swanps bordering the water courses. Until of late years it has been eut only on speeial orders for low-prieed stuff intended for tenporary purposes. As an instance, the fact may be cited that the millions of feet of squares sawn timber and of lumber required for the buildings of the New Orleans World's Exposition were mostly Loblolly Pine, sawn at Pearlington, Miss. Since the introdnction of the dry-kiln it is extensively used for flooring and inside finish. In the fresh, deep soil of light loam of the coast plahn and the valleys in the npper part of the pine belt-the region of mixed growth-this tree is found in great perfection. In these distriets it furnishes clear sticks of from 50 to 60 fect and over in length. A eonsiderable proportion of the long and heavy sticks of hewn timber reaching the Mobile market for export as "piteh pine" coming from the npper division of the coast pine belt in Alabama are Loblolly Pine. The timber of the Loblolly Pine from the table.lands of north Alabama is of excellent quality, with but a small proportion of sapwood from 2 to 3 inches on a radins of from 10 to 12 inehes, heavy, of a fine elose grain and henee of greater dnrability and strength. The inmber from that region finds a ready market, being used for all the purposes of the house carpenter, and is indiscriminately sold with the product of the Shortleaf Pine.

On the table-lands of the Warrior coal field the Loblolly Pine is better developed than in any other part of this or the adjoining State of Mississippi. If not fomd in compact forests of any eonsiderable expanse, it torms bodies of heavy timber eovering the flat and badly drained traets, from a few to many acres in extent, assoeiated with the hard wood growth peenliar to a moist soil. It might be said that abont one-half of the pine timber growth of these highlands consists of the Loblolly P'ine.

The following measnrements have been taken of trees felled in Cullman Comnty, Ala., from heavily timbered land several acres in extent:

Measurements of four trees.
\begin{tabular}{|c|c|c|c|}
\hline $\begin{array}{c}\text { Riugs on } \\
\text { stump. }\end{array}$ & $\begin{array}{c}\text { Diameter } \\
\text { loreat Ligh. }\end{array}$ & $\begin{array}{c}11 \text { eight of } \\
\text { tree. }\end{array}$ & $\begin{array}{c}\text { Length of } \\
\text { timber. }\end{array}$ \\
\hline & Fnehes. & Fiet. & Feet. \\
\hline 78 & 21 & 101 & 41 \\
156 & 24 & 103 & 40 \\
100 & 22 & 104 & 45 \\
137 & 13 & 106 & 57 \\
\hline
\end{tabular}


In Lonisiana, west of the Mississippi bottom, the Loblolly Pine is found frequently seattered in the level woods bordering upon the grassy marshes of the eoast. North of the region of the Longleaf Pine on the pine flats with a poor, sandy, undrained soil, between Lake Beaudean and Bayon Dauehitt, extending to the Arkansas State line, this speeies forms the prineipal tree eovering. The tree is ent only for loeal consumption in the absenee of means of transportation.

In Arkansas heavily timbered for'ests of Loblolly Pine eover the flat woods in the southeastern part of the State and the region of the Tertiary and Post-'Tertiary formation. The lower levels in the rolling iplands are eovered with heavily timbered forests of the Loblolly Pine. It forms in this State an important factor in the manufacture of lumber. From observations made in the logging eamps in eonneetion with the prineipal points of produetion along the St. Louis and Iron Mountain Railroad south of Gurdon and on the St. Louis and Southwestern Railroad it ean be safely assumed that about one-half of the lumber eut and shipped as "Yellow Pine" to Northeru markets from sonth western Arkansas is Loblolly Pine, the other half being Shortleaf. The flood plain of the Little Missouri River and the Ouachita River is eovered with extensive forests of this tree. The deep soil, a stiff sandy loam, flooded after every rainfall, produees a heavy and finely developed timber growth. Upon one aere, representing fairly the average of the merehantable timber standing, 30 trees were eounted of from 12 to 48 inehes in diameter at breast high; of this number were found: One tree 48 inelies in diameter at breast high, length of timber estimatel at 40 feet; one tree 36 inehes in diameter at breast high, length of timber estimated at 35 feet; three trees 30 inches in dianeter at breast high, length of timber estimated at 35 fcet; seven trees 23 inches in diameter at breast high, length of timber estimated at 35 feet; three trees 15 inches in diameter at breast high, lengtl of timber estimated at 35 feet; fifteen trees 12 to 15 inehes in diameter at breast high, length of timber estimated at 24 feet.

Measurements of four trees.

\begin{tabular}{|r|r|r|r|r|}
\hline $\begin{array}{r}\text { Rings on } \\
\text { stump. }\end{array}$ & $\begin{array}{c}\text { Dianreter } \\
\text { at breast } \\
\text { high. }\end{array}$ & $\begin{array}{c}\text { Height of } \\
\text { tree. }\end{array}$ & $\begin{array}{c}\text { Diameter } \\
\text { below } \\
\text { crown. }\end{array}$ & $\begin{array}{r}\text { Length of } \\
\text { timher. }\end{array}$ \\
\hline & Inches. & Feet. & Inches. & Feet. \\
\hline 85 & 17 & 85 & 12 & 47 \\
150 & 21 & 105 & 14 & 58 \\
83 & 20 & 96 & 12 & 37 \\
110 & 22 & 109 & 12 & 68 \\
\hline
\end{tabular}

The timber of these trees was almost free of any defeets; sap from 3 to 4 inehes on radins.

In Texas this speeies is distribnted in greater or less abundanee to the sonth and southwest of the Shortleat P'ine region over an area exeeding 6,800 square iniles. There is even less basis for statistieal statements regarding timber standing at present and consumption than for the Shortleaf Pine, sinee it is not even reegnized as a partienlar speeies, and always eut together with the latter, espeeially between the Trinity and the Brazos rivers. No data have lately been obtained of the amnual production of lumber derived from the Ioblolly l'ine forests in this State, but in the light of the statements of the Tenth Census' it must eontribute largely to the timber supplies of this State. Aeeording to this anthority, the merehantable timber of Loblolly standing in 1890 was estimated at $20,907,000,000$ feet, board measure, and the eut for the same year at (i1,500,000 feet, board ineasure.

\section{PRODUCTS.}

VALUE AYD USES OF THE WOOD.

Considered solely as the souree of furnishing an abundant and cheap material for purposes where strength and durability are not the first considerations, the Loblolly Pine is entitled to talie its place among tlie timber trees of the greatest importance. The average tree of full growth, as it is generally found in the original forest on a poorer soil, furuishes timber with a fair proportion of heartwood, with stieks of from 30 to 50 feet and over in length, free from blemish, and generally in no way inferior to the timber of the Shortleaf and sometimes oven of the Longleaf Pine. In firct, the seleeted lumber of loblolly elasses with the latter in many of the markets for the sane 
uses by the louse carpenter, while the inferior grades are largely consumed for secondary purposes. Of late years the value of the limber even of lower grades has bcen mueh euhanced by the process of kiln-drying, now universally introduced into the inills. After the removal of the water from the sapwood by exposure to a current of lieated air, the lumber loses its pronencss to get discolored or to "blue" by the rapid development of the mycelin of a fungus and greatly gains in its capability of a good finish, as well as in durability, and is thus rendered snitable for many purposes for which, without such treatinent, it would be rejected.

The consumption of Loblolly Pine lumber is constantly on the increase in the markets of the North, as the lumber of the White Pine becomes scarce and nore expensive. The sappy tinber of. second growtlı is every year coming more in demand, especially in foreign markets, where this eheap timber is rendered durable by ereosoting. In the highest state of perfeetion, which is only attained in the regions most favorable to its development, no other pine was deemed of higher value or was more eagerly songht after for masts and other heavy spars of ships. Before the use of iron in naval construction for these purposes, the Loblolly Piuc timber of largest size was eagerly contraeter for in all the Southern ports by every one of the maritime powers of Europe. In eonsequence, the trees which could furnish timber of the dimensions and qualities required for such purposes have become exceedingly scarce, and can be said to have almost entirely disappeared.

The Rev. M. A. Curtis, in his aeconnt of the Loblolly Pine, ${ }^{1}$ quotes the following statement on the habitat and the dimensions of this tree, from the pen of Mr. E. Ruffin, of Virginia, which, illustrating a featnre of the life of the Sonthern forest forever past, I ean not refrain from intro. ducing here:

This (Slash Pine) tree grows only on low, moist lands, and is the better for timber and grows larger in proportion to the richness of the land. Among other gigantic forest trees on the rich and wet Roanoke swamps, mostly of oak, poplar, gum, etc., the few pines which yet remain tower above all others; I have visited several standing trecs and stumps of others which have been ent down and which measured 5 feet in diameter, and were supposed to have been from 150 to 170 feet high.

In evidence of the dimensions of the trees, the writer gives the sizes of the squared sticks cut in Bertie County, made into a raft, and shipped in 1856 by way of the Dismal Swamp Canal to New York. These sticks varied from 50 to 86 feet in length by a mean diameter of from 26 to 31 inches, eontaining from 347 to 537 cubic feet each. Remarking further:

All of these sticks are ncarly all heartwood; thence it follows that the proportion of heartwood lunst have been very large, the timber must have been resinous or it wonld not le good, and it must be dnrable or it wonll not serve for masts and other long spars for ships exposed to the alternations of wetting and drying, and for which only the best materials are pernitted to be nsed.

The inferior growth of the Loblolly Pine furnishes vast supplies of cordwool. Immense quantities are shipped from the coast of Virginia and North Carolina to the large cities on the Atlantic seaboard. It is chiefly used where a brisk flame with a quick heat is reqnired, viz, in bakeries, brickkilns, and the kilns of potteries. In its fuel value, the wood of this tree ranks with the better class of resinous trees. Large quantities of the wood are also used for the burning of chareoal.

RESINOUS PRODUCTS.

Regarding the production of resinous products from this pinc there has existed a wide divergence of statements. A. F. Michaux states that this tree affords turpentine in abundance, but of a less fluidity than that of the Longleaf Pinc, and suggests that as it coutains more sapwood a deeper incision would yield a larger product. Rev. M. A. Curtis follows Michaux in this statement, and the writer, relying $n$ pon the information from operators in south $\mathrm{Alabama}$, was also led into the error of supposing this tree to yield an abundance of resin for clistilling, similar to the freeflowing resin of the Cubin Pine, and published a statement to the effect that this trce was tapped wherever found. A trial box made at the request of the writer seemed to confirm the opinion as to the character of the resin. It appears now, however, that the tree boxed (not inspected by the writer) could not have been a Loblolly, for lately a number of true Loblolly Pines, tapped accidentally in a turpentime orehard, were found in Washington County, Ala., and showed that the resin 
of this pine does not flow freely and hardens so rapidly on cxposure that it ean not be profitably worked. An cxperienced opcrator at the place confirmed this to be the experience everywhere with this kiud of pine. The statements regarding the use of this tree for its resiuous product can therefore ouly be explaiued by a confusion of names applied to the different pines, and it was most likely the Cuban Pine to which the operators referred. (See additioual notes on p. 133.)

II a report, lately published by the State geologist of North Carolina the remark is made: "It is said that the crude turpentine of the Loblolly Pine has so much water in it that it yields only a poor spirits of turpentinc." 1 This, to be sure, is a misconception; but the statemeut confirms the fact that this species is not tapped for its resiu, which had also been observed by the writer a short time previously in the Loblolly Piue forests of North Carolina as well as South Carolina and Georgia.

From an extensive series of analyses of the resin of fresh specimcus of both Longleaf and Ioblolly Pine collected in Georgia and South Carolina, it appears that the wood of Loblolly contains but little less resin than that of Longleaf; that the distribution of resin in the $\log$ is practically the same, and, what scems nost remarkable, that the composition of the resin, as far as the relation of spirits of turpentine and rosin is concerned, is nearly the same (being quite variable in both), so that the absenec of free "bleediug" or abundant resin exudation can not be duc to a lack of liquid oil, but must be caused by other pliysiological peculiarities.

\section{NOMENCLATURE AND CLASSIFICATION.}

The Loblolly and lialf a dozen other species, mostly Pacific and Mexican, ${ }^{2}$ form a natural gronp of timber trees included in Euglcmann's Eutcede, which might fitly be designated as the gronp "torch pines," and can be characterized as embracing trces, mostly of larger sizc, with more or" less resinous, coarse graiued wood, long leaves by thrces in a fascicle, and with lateral cones provilled with thick, woody scales bearing a stout, sharp prickle. The distinctive characters of this spccies lıve been early recognized by Plukenet, one of the enrliest writers on American plants ${ }^{3}$ and Linneus described the tree under the name of Pinus ted $a^{4}$ which was adopted subsequently by all botanists. The name given to this pine by Linnæus in $\mathbf{1 7 5 3}$ has never been changed. In 1789 Aiton established a variety, 1'. tıeda $\alpha$ tenuifolin (Hort. Kew., III, 368), which, however, has not received recognition.

\section{BOTANICAL DESCRIPTION AND MORPHOLOGY.}

Leaves three in the elose, elongated sheath, 6 to 9 inches long, slender, stiff, rigidly pointed, ehanncled, and strongly keeler on the upper side, of a pale green eolor; cones nearly sessile, single, in twos or threes, roundish-ovate or ovate-oblong, about 3 inches long, with the seales hard and woody, the pyramidal apophysis with a strong, recurverl prickle; seeds small, their wing an ineh or over long.

This species is easily distinguished from its most frequent associates-the Lougleaf and Shortleaf pine-by its slightly glaucous foliage at all seasous; by its more slender and almost smooth terminal buds from the former; and from the latter by the more robust shoots and buds; and from both the species named, and also from the Cuban Pine, by its characteristic cones.

$$
\text { HOOT, STEM, AND BRAŃCII SYSTEM. }
$$

The stont taproot of this pine is assisted by powerful laterals which divide into numerous branches and desecud into the soil, usnally at a short distance from the trunk; but where a hard, conruact subsoil is encountered they are often scen fo run for a greater or less distance near the surfacc. In the localitics most favorable to its growth, the massive trunk of the Loblolly Pine is in its dincensions not surpassed by any other pine of the Atlantic forest region. In sneh eases the tree at tains a lieight of 120 to 150 feet and over, with a dianeter of from 4 . to 5 feet breast high, and with the trunk clear of limbs for a length of from 60 to 80 feet.

1 The Forests, Forest Lands, and Forest Produets of Lastern Forth Carolina, by IV. W. Ashe. 13ulletin 5 of tho Geological Survey of Nortlı Carolina, 1895.

Bngelmann, Rovision of the Genus Pinns. Transactious of the Academy of Scieuccs, St. Louis, Vol. IV, p.

177. 1886 .

Plukenet: Alnagestum botanicum. Loudon, 1696.

4 Linnulus: Species l'luutarum, 1'. 1000. 1753. $17433-$ No. $13-8$ 


\section{FXPLANATION OF PLATE XIX.}

[Figures natural size, except when otherwise notel.]

Fig. $a$, branch bearing male inflorescence; $b$, young faseicle of leaves (spring); $c$, 1 , forms of uature lears: transverse section of leaf bundle showing struetural characters of the leaf (as explainal for Pinus echinata) $f$, $f$; magnified 20 diameters.

122 


\section{Bulletin No. 13, Division of Forestry.}

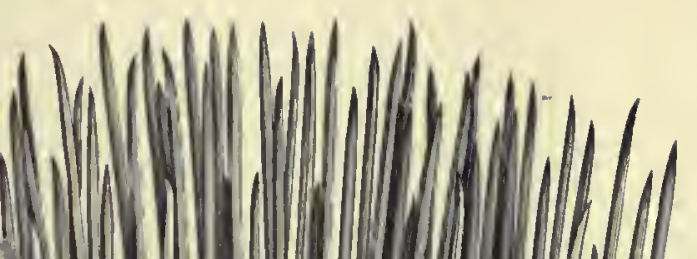

1) M.

1 No

1)WW

m.N.

1 .

.

.

.

.

.

.

(1)

.

.

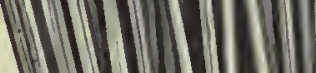

.

.

.

.

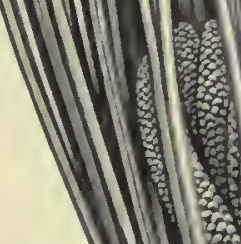

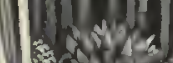
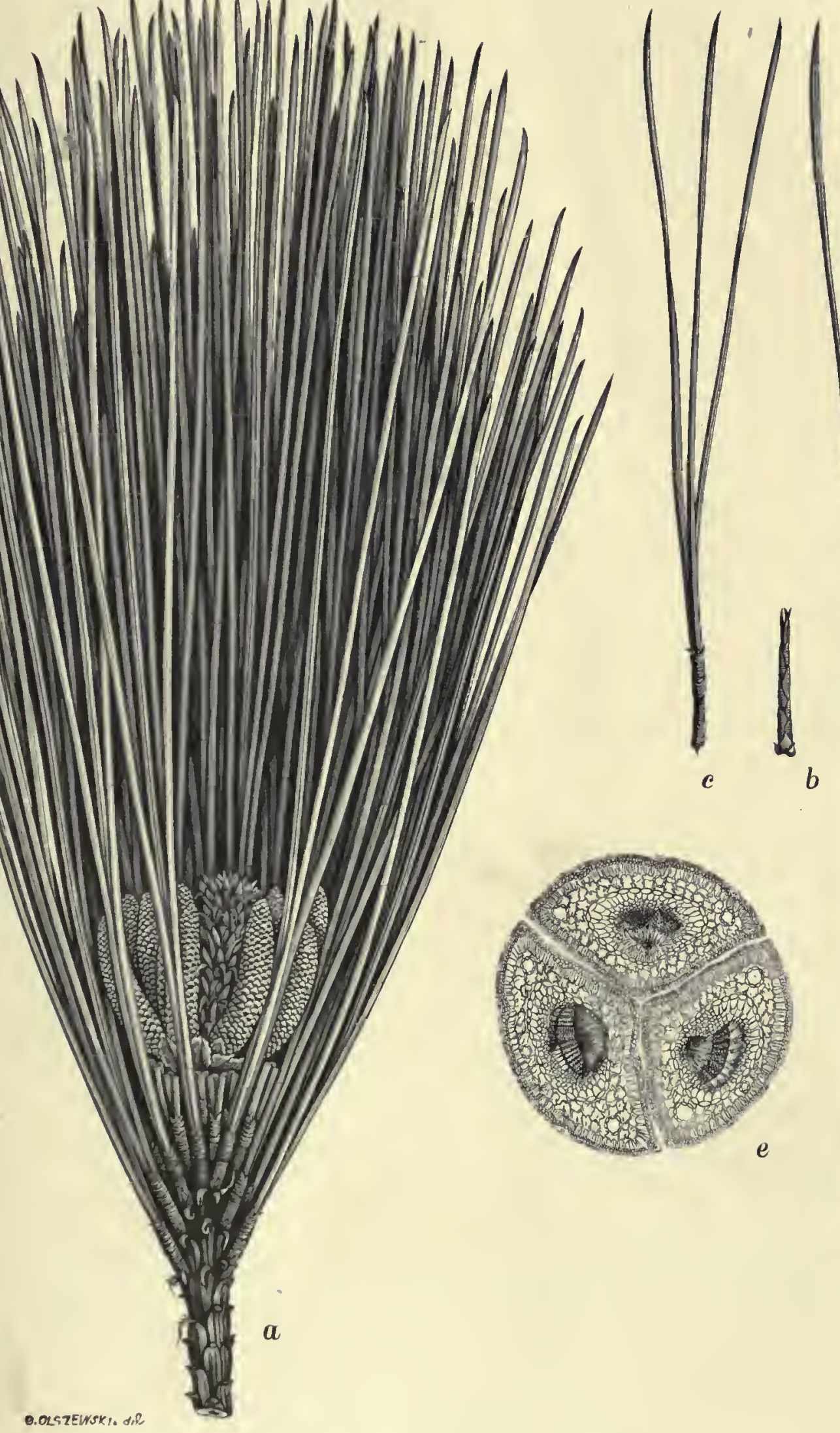

Such trees, however, have at no time been plentiful and at present are larely met. In its average growth the diameter of the trunk, breist high, measures from 20 to 24 inehes, and the height from 95 to 110 feet. In wet places, somewhat distended at its base, the trunk tapers very gradnally to the crown, whieh eovers from one-third to one half of its height. The lowest limbs are horizontally spreading, and toward the npper part of the tree they beeome gradually more erect. The largest linbs are rarely found over 20 feet in length. The primary branehes dividing in : regular order of ramification into unmerous branches and branchlets, the erown becomes fnll and compact toward the top. The bark of the full-grown tree is, in the lower part of trunk, from 1 to $1 \frac{1}{2}$ inches thiek, generally rough, of a grayish eolor, beeoming smoother, flaky, and reddish browu as the tree grows older.

$$
\text { LEAVES. }
$$

The leaves are united, to the number of three, in a smooth, close sheath, whiel in the yonng foliage is about 1 inch long and in the next season scareely half that length. (PI. XIX, $c, l, d$.)

In the bushy growth of less than ten years the leaves are searcely 5 inclies in length, reseinbling closely the foliage of the Shortleaf Pine of equal age. Prof. L. Ward notes this resemblance as a singular fact, which, as he very pointedly remarks, has the effect of obseuring the gradnal appearance of this species among the young growth of the Shortleaf Pine. ${ }^{1}$ In the following years the leaves are from 7 to 9 inches loug, less densely crowded on the slender branches than in the Longleaf and Cnban Pine; the foliage is of a more open spray, and persisting to the third year. The leaves are stiff, slightly twisted, ronghish on the finely sermlated edges and the prominent midrib, channeled on the upper side, abruptly tipped by a rigid, sharp point (Pl. XIX, $c, d$ ), and of a pale green eolor. They are scarcely one-sixteenth of an ineh wide, abont half as thick, and present in the cross section on the dorsal side a convex and on the ventral side a strongly triangular ontline. Examined under the microscope they show on both surfaces from 10 to 12 rows of rather large breatling pores (stomata), alternating with rows of numerous hypodermal or strengthening eells, in several layers. The cells of the bundle sheath are thin walled; the fibro. vasenlar bundles are, on their ventral side, smrronnded by a single row of small strengthening cells. The rather large resinous ducts, from 3 to 5 in number, are peripheral, and plaeed irregularly mostly about the angles (Pl. XIX, c); sometimes smaller ducts are observed elose to the bundle sheatl.

\section{FLORAL ORGANS.}

The staminate flowers are crowded, from 18 to 20 in number, below the apex of the youngest shoot. (I'l. XIX, a.) They are from three-fourths to one inch long, of sulphur-yellow color, and surrounded at the base by from 8 to 10 ovate to lanceolate, leathery, involucral seales; the lowent pair is mueh shorter than the others and strongly keeled; those of the nppermost row are longest, narrow, laneeolate, and reflexed. 'The anthers are crowned with an erect orbicular crest. After the discharge of the pollen the flowers are gradually shed. The pistillate flowers form an oblong, erect catkin, borne on a short stalk, singly, in pairs, sometimes 3 to 4 , below the apex of the shoot $(\mathrm{Pl} . \mathrm{XX}, a)$ of the season, which by the time of blooming has already reached a length of several inches and is eovered with the well-alvaneed leaf buds. Including their stipe, the female aments are about one-half to three-fourths of an inch long, surromided by from 15 to 20 involneral seales similar to those of the staminate flower. The earpellary seales are ovate, lanceolite, tapering to a sharp, ereet, and somewhat reflexed and twisted point. The suall bracts subtending the scales are orbicular, scareely covering their base.

The flowers open, in the coast region of the lower Southern States, about the seeond week of March (Mobile, Ala., March 15 to 20 ), and in the interior from four to five weeks later (Cullunan, Al:1., $\Lambda$ pril 2:3).

Immerliately after pollination the female catkins inerease rapidly in size; before ten days have passed the earpellary scales liave doubled in size, and their tips beeome stiffy ereet, the bracts having remained stationary in their growth, and the fertile shoots having grown to the length of $s$ inches and over. This period passed, the growth of the conelets during the rest of the season proceeds very slowly. 


\section{EXPIANATION OF PIATF; XX.}

Fig. $a$, branch bearing two subterminal aments of female flowers at end of shoot of the season; $b$, immature cone of one season's growth; $c$, matnre closed cons of two seasons' gruwth; $d$, mature open cone iftur sherling seed; e, cone scale, onter or lorsal side, showing the broad umbonate apophysis cul with its sharp transverso ridges and the stout reflexed prickle; $f$, inuer or ventral view of the same with the sued in place; $g$, seed and wing detached. 


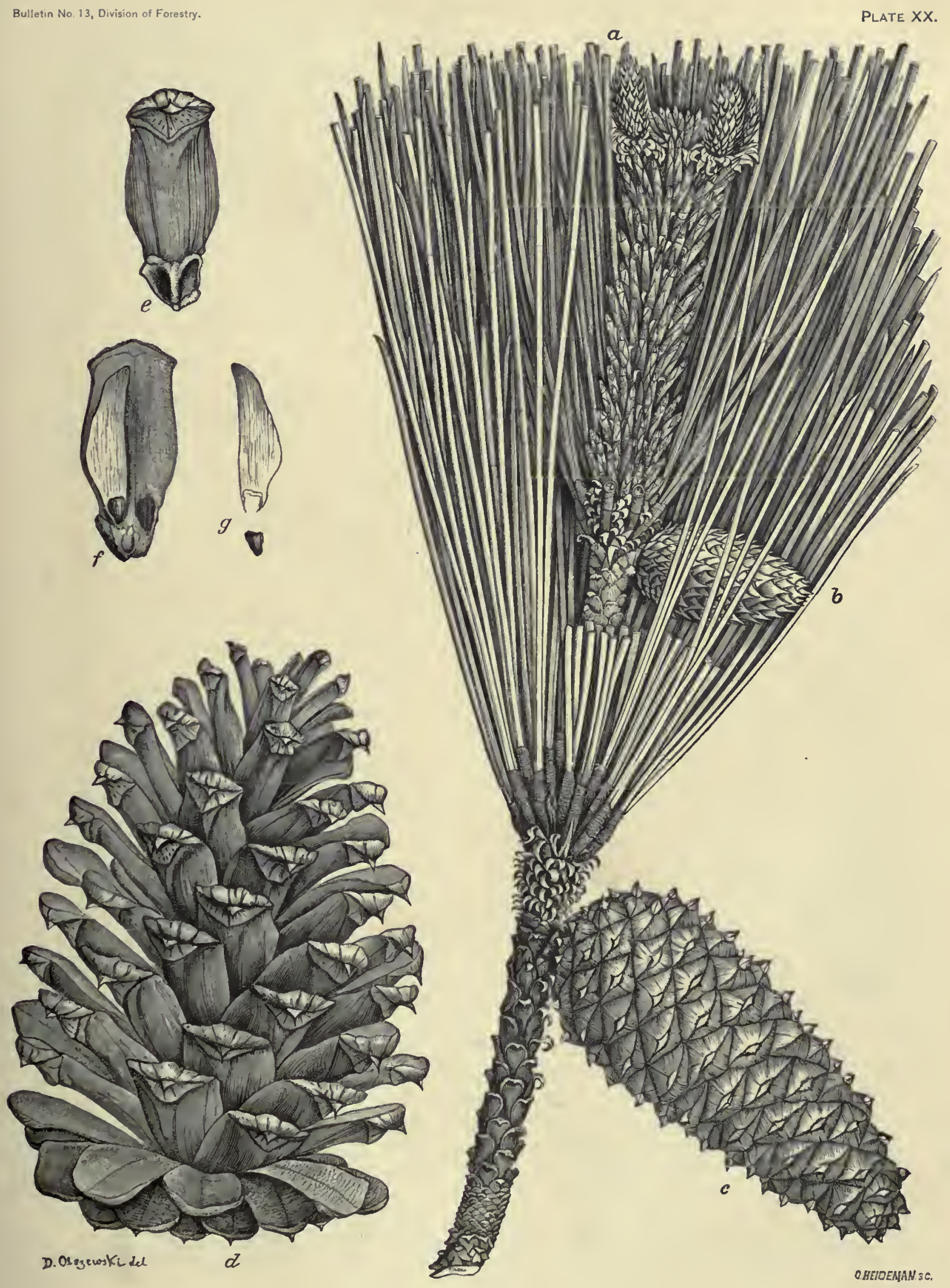

Pinus teda: female flowers, Cone, and Seed. 

At the beginning of the second season the immature eones are scareely one-half inch wide and less than an ineh long ( $\mathrm{Pl} . \mathrm{XX}, b$ ), and from that time on inerease in size and by the following Oetober have reaehed their maturity. The ripe cones are lateral, almost sessile, broadly conical or ovate in shape, rarely orer 3 inches in length $(\mathrm{Pl} . \mathrm{XX}, c, d)$, when fully opeued $1 \frac{1}{2}$ to 2 inches wide, aud of a light wood-brown color. The pyramidal, swelled, exposed ends (apopliyses) of the hard, woody seales with a sharp transversal ridge are armed with a stont, straight, or slightly reflexed prickle. (Pl. XX, e.) Having reached their maturity, the cones open slowly, the seeds being gradually diseharged during the fall and winter seasons. The eones are apt to remain on the tree till the end of another year, aud when they finally separate from the branch by the breaking loose of their very short stalk, leave none of their basal seales behind. The seeds are irregularly truncate or rhomboid in outline, inflated, sharp-edged, with two to three more or less distinet ridges, roughish, dark brown to almost blaek, and surrounded to the base by the narrow border of their delieate wing (Pl. XX, $g, f)$, whieh is over an ineh long and from one-fourth to one-eightl of an inch wide.

THE WOOD.

Among the pines of the southern Atlantie forests noted for their eeonomie importance the Loblolly is held lenst in value as a timber tree. This opinion is eliefly founded on the lesser durability of its wood, being more speedily given to decay under the eombined influences of dampuess and air, and also on the supposition of its being of less strength than the other pine timbers. There is scarcely a timber tree existing that shows wider differenees in the quality and value of the timber. This is strikingly denonstrated when the timber of a tree of full average growth, grown on land broken by the plow, is compared with the timber of a tree in its highest perfectiou taken from the primeval forest. In the former ease the wood is coarsegrained, sappy, aud quiek to decay. In the latter it is finer grained, resiuous, has less sapwood, and approaehes the timber of the Longleaf Pine.

In general, the well-marked, lighter-eolored sapwood is quite broad, and usually about 4 inehes, frequently 6 inehes and more. It is wider iu young, thrifty trees, narrower in old and stunted or slow-grown timber; forms about 60 to 70 per cent of the total volume of stems over one hundred years of age, and 80 to 90 per eent of trees sixty to one hundred years old. The formation of heartwood does not begin before the age of twenty-five, the process being retarded as the tree, or better the particular part of the stem, grows older, so that while the iunermost sapwood in a $\log$ or disk with twenty-six rings is twenty-five years old, the innermost sap ring is thirty-five years old when the log attains the age of forty-five; it is forty-five years old when the log is sixty-five, and about seventy or even more years old when the $\log$ reaches the age of one hundred and fifty or two liundred. It follows that the sapwood is formed of fewer rings in young trees and in the upper part of older stems, but owing to the greater rapidity of growth in these parts the width of the sapwood does not always follow this same law. Sinee neither width of the ring, nor that of the denser summerwood, the thickness of the cell walls, nor any other important struetural feature is elianged when the wood of any ring changes from sap to heart wood, the prevalent notions of sapwood being neccssarily either coarse or fine grained, light, and weak, are erroneous. The sajwood of a young, well-grown tree is eoarse-grained, heavy, and stroug; that of an old tree is finc grained, light, and, weak. Since durability on exposure is not to be expeeted of the sapwood of any pine, the prejudiees against the sapwood, and therefore all young tinber of this particular kind, are $n$ warranted. With proper treatment, it will serve all purposes for which any pine wood of its grain and weight ean be employed in finishing.

Owing to the great amount of water-soaked sapwood the weight of green Loblolly timber is very great, varying eliefly between 50 and 55 pounds to the eubic foot, with the sapwood commonly approaching 60 pounds to the eubic foot. Kiln-dried, the wood of the entire trunk of trees one hnudred to one hundred and fifty years old weiglis about 33 pounds per eubie foot. In sueh trees the wood of the $\log 50$ feet from the ground is about 20 per cent lighter (and weaker) than that of the butt $\log$, and the wood next to the bark in the butt $\log$ is 15 to 20 per eent lighter than the wood of the inuer fifty to sixty rings.

In strengtli the wood of the Loblolly varies ehiefly with weight (the same degree of seasoning always presumed), and keeping this in mind, compares favorably with that of any other conifer. 
For well-sensoned wood, the following figures represent the average of hundreds of tests on specimens specially collected for this purpose:

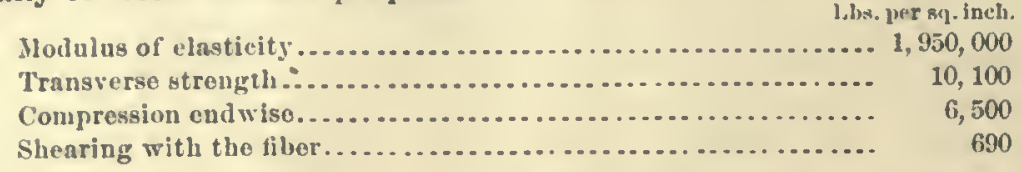

Since the average weight of the test pieces was 40 pounds per cubic foot, being heavier than the average weight of the wood, these figures innst be taken abont one-sixth lower than given above to represent the true average for the wood of the species.

Like the wood of most conifers, that of Loblolly dries easily and rapidly. In doing so the green lumber loses a large amount of water, dependent chiefly on the proportion of sapwool. Thongh quite variable, the water in fresh sapwood commonly forms 50 to 60 per eent of the weight, while in lieartwood it little exceeds 25 per cent.

The shrinkage consequent on drying amonnts to 11 to 12 per cent of the volume; is greater in the hmber of the butt than in that from the top logs, varying in this respect from 13 per cent at the butt to abont 10 per cent in the top, a difference which appears due to the differenee in the weight of the wood of the different sections. As in other pine, abont two-thirds, or 7 to 5 per cent, of this slrrinkage falls to the tangent (i. e., is along the rings) and abont 4 to in per cent to the radins.

For kiln-drying the wood may be taken fiesh from the saw and belıaves extremely well, suffering no great injury, a fact which has greatly enhanced its value ly facilitating its exploitation.

For the details of wood structure, eonsult the comparative study by Mr. Roth appended to these monographs.

\section{PROGRESS OF DEVELOPMINT.}

The crops of seed are produced quite abundantly every year and copionsly dispersed over the vicinity of the mother trees by the wind; the offspring quickly takes possession of old fields and clearings in the forest.

The secds germinate in the early spring. The ends of the cotyledons remain for a short time after germination inclosed in the endosperm. The number of the germinal leaves (eotyledons) is mostly six, rarely seven. At the time of the unfolding of the cotyledons thie lower (hypoeotyledonary) part of the axis of the plant is abont 1 inch in length. The rootlets are half that length, and are provided with scveral acropetal secondary rootlets. The canlicle grows rapidly, ancl is soon covered with the stiff, needle-shaped, and strongly serrulated primary leaves. Before the spring season lats passed the bundles of secondary or foliage leaves make their appearance in the axils of the former. At the close of the summer seasont the plantlet has attained a lieight of from 6 to 8 inches, the upper part of the stem covered with foliage leaves, the acerose primary leaves of the lower part having completely withered. In examining a large number of young plants never less than three leaves in a bundle have bcen found dnring this or any subsequent stage of the growth. With the second year the primary leaves have all become rednced to the ordinary form of the leaf bract-lanceolate, acnminate, with fimbriate white liyaline ed ges and tips.

In all the specimens examined it was fonnd that the growth of the main axis proceeded less rapidly chring the second season, but produced a regular whorl of from three to four lateral axes. At the close of the second year the main stem rarely exceeds 10 inches in height.

At the cud of their third year the plants are from 18 to 20 inches high, the stem being from one-fonrth to five-sixteenths of an inch in thickness. The branches, forming regular whorls, are erect and prodnce in their turn whorls of secondary order. The root system shows a corresponding increase, the taproot being from 6 to 18 inches long, with unmerous stont lateral roots.

\section{RATE OF GROWTH.}

With the fourth year the Loblolly line enters seemingly upon the period of quickest growth. As ascertained by many measurements, the trees at the end of their fourth year average 3 feet in lieight and from one-half to seven-eighths of an inch in diameter, and at the end of the fifth year measure nearly is feet and from 1 to 1 inches in diameter. At the beginning of the seventh year 
the tree attains a height of 10 feet, and with the elose of the first decade trees are found 12 to 16 feet high and from 23 to 3 inehes in diameter. Some trees begin to mature their first cones by the tentlı year.

The above measurements were made in 1890 in the vieinity of Cullman, Ala., on trees taken indiseriminately from the midst and near the border of a dense pine thicket eovering a field plowed for the last time in 1882, and from an adjoining opening in the forest proteeted from fire and but rarely used for pasture.

According to a number of measurements made of trees in the sonthern Atlantic States, the Gulf region, and southern Arkansas, the Loblolly Pine reaches at the tenth year, on the average, a height of 20 feet, doubling this height during the suceeeding deeade. During this period of quiekest growth the inerease in height proceeds at the rate of 2 feet per aunum, and trees twenty years old average $4 \frac{1}{2}$ inehes in diameter breast high. At the age of fifty years the trees are from 65 to 75 feet in heigint (average about 70 feet) and 15 inches in diameter breast ligh. The anuual increase for tinis period of thirty years is about 1 foot in height and 0.35 ineh in dianeter. From numerous observations it appears that the Loblolly Pine attains the fullness of its growth at the age of oue hundred years, with a height, on the average, of 110 feet and a diameter breast high of 2 feet, the length of merehantable timber varying between 50 and 60 feet. The annual rate of height growth during the second half century is about eight-tenths of a foot, and the diameter growth cighteen one-hundredths of an inch. Heneeforth the growth in height remains almost stationary. A dozen trees from one liundred to one hundred and fifty years old were found to vary from 99 to 125 feet in height, with a length of trunk free from limbs of from 60 to 68 feet and from 19 to 27 inehes in diameter at breast height.

From the annexed tabulated records of growth it beeomes evident that under similar eonditions of soil and exposure the rate of inerease for the various stages of growth show but slight differenees in localities widely distant from each other.

TABLE: I.-Growth from five to fifty years.

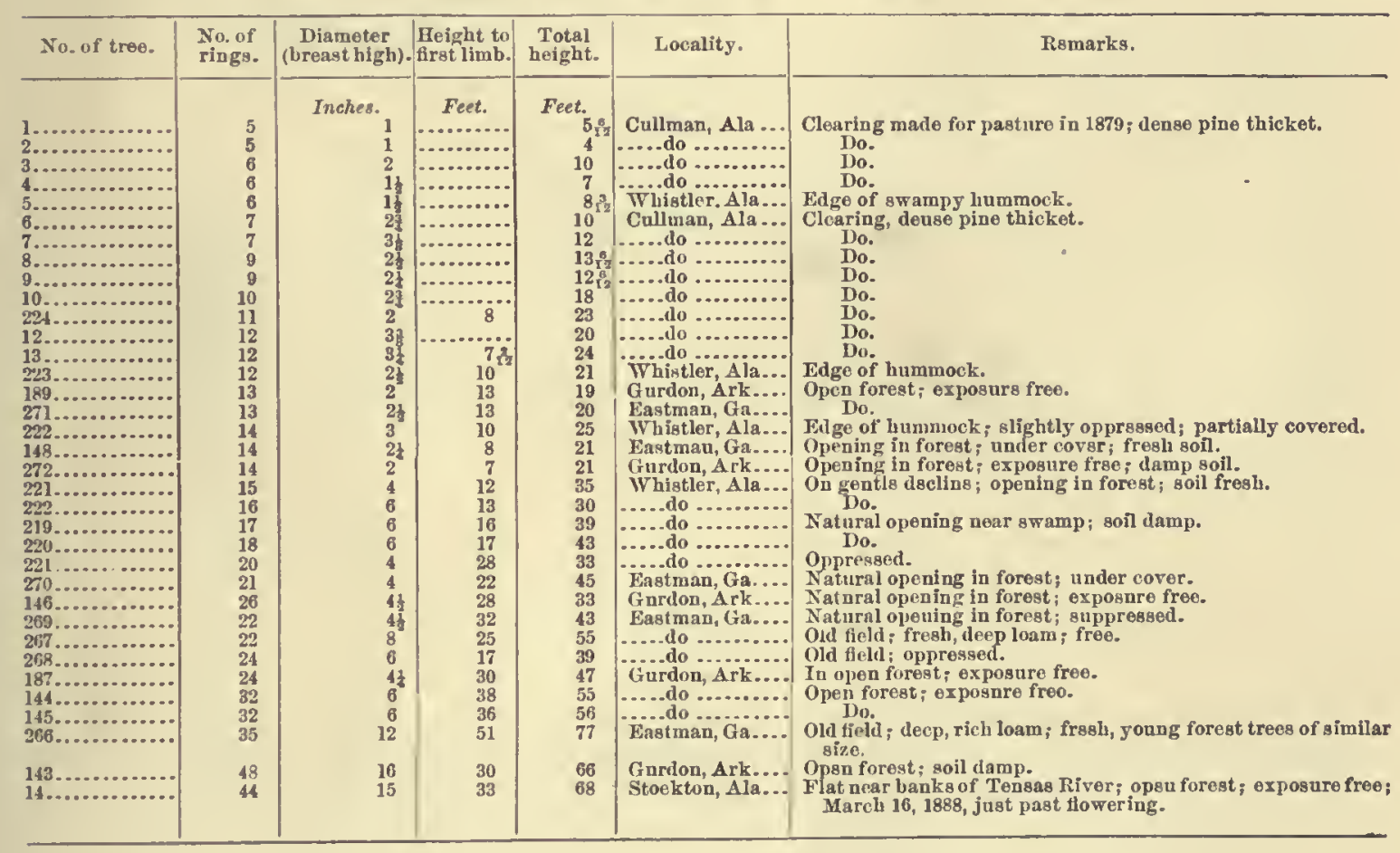


TAlus. II.-Groirth of Loblolly Pine (l'inus trda) from fifly to one hundred and ffly-six years.

\begin{tabular}{|c|c|c|c|c|c|c|c|c|}
\hline \multirow{2}{*}{ No. of tree. } & \multirow{2}{*}{$\begin{array}{c}\text { Rlags } \\
\text { in } \\
\operatorname{trnmp.}\end{array}$} & \multicolumn{3}{|c|}{ Dlameter. } & \multirow{2}{*}{$\begin{array}{l}\text { Ileight } \\
\text { to tirst } \\
\text { limb } \\
\text { (length } \\
\text { of tia. - } \\
\text { ber). }\end{array}$} & \multirow{2}{*}{$\begin{array}{r}\text { Total } \\
\text { helght. }\end{array}$} & \multirow{2}{*}{ Locallty. } & \multirow{2}{*}{ IIaljtat, and other remarks. } \\
\hline & & $\begin{array}{l}\text { Brenst } \\
\text { high. }\end{array}$ & $\begin{array}{l}\text { Aeruss } \\
\text { stump. }\end{array}$ & $\begin{array}{l}\text { Below } \\
\text { erown. }\end{array}$ & & & & \\
\hline 300. & 63 & $\begin{array}{c}\text { Tuches. } \\
11\end{array}$ & $\begin{array}{c}\text { Inches. } \\
131\end{array}$ & $\begin{array}{r}\text { Inches. } \\
\text { 9f }\end{array}$ & Feet. & ret. & 1Adgoland, S.C... & Low pine barrens, edge of linmmock, soil daup, ex. \\
\hline 265. & 70 & 10 & 16 子ु & 93 & 57 & 80 & Fastman, Ga.. & $\begin{array}{l}\text { old field, abanloned ono hnndred years ago; typical } \\
\text { for oldest seeond growth. }\end{array}$ \\
\hline 261 . & 73 & 22 & & & 50 & 94 & .....do do & $\begin{array}{l}\text { Close to edge of swimp; open forest; soll wut; expo- } \\
\text { suro free; saptrood } 4 \text { inches. }\end{array}$ \\
\hline $\begin{array}{l}302 . \\
24 . .\end{array}$ & $\begin{array}{l}74 \\
80\end{array}$ & 12 & 109 & 61 & $\begin{array}{l}35 \\
41\end{array}$ & $\begin{array}{r}80 \\
101\end{array}$ & $\begin{array}{l}\text { Ridgeland, S. C... } \\
\text { Cullinan, Ala.... }\end{array}$ & $\begin{array}{l}\text { Close to edgo of kwam p: somew lat suppressed. } \\
\text { Swampy swale; open forest; exposire ree. }\end{array}$ \\
\hline $240 \ldots \ldots \ldots \ldots$ & $\begin{array}{l}80 \\
80\end{array}$ & 18 & 10 & 91 & 60 & 103 & Kldgeland, s. $\mathrm{C} .$. & Swampy huminock; exposare partially free. \\
\hline 111. & 83 & 20 & 20 & 151 & 37 & 90 & Gurdon, Ark..... & Low, wet, pliny woods: exposiro partially free. \\
\hline $139 \ldots \ldots \ldots \ldots$ & 85 & 17 & $15 t$ & $12^{\circ}$ & 47 & 88 & *i.do ....... & Low, wet, jiny wools ; exposure free. \\
\hline $217 \ldots \ldots \ldots \ldots \ldots$ & $\begin{array}{l}87 \\
90\end{array}$ & $\begin{array}{l}21 \\
22\end{array}$ & (........ & .... & $\begin{array}{l}40 \\
46\end{array}$ & $\begin{array}{l}105 \\
104\end{array}$ & $\begin{array}{l}\text { Whistler, Ala .... } \\
\text { Cullman, Ala.... }\end{array}$ & $\begin{array}{l}\text { Jow, open forest; aoil damp; exposure free. } \\
\text { Wet swale; sandy loam; open forest; freo. }\end{array}$ \\
\hline $300 \ldots \ldots \ldots \ldots$ & 95 & 19 & 19 & 12 & 53 & 112 & Kidgeland, S.C... & Edye of s wanp; slightly opprcesed ; sapwood 5 luehes. \\
\hline $297 .$. & 100 & 27 & 261 & 183 & 56 & 118 & ...... do ............. & $\begin{array}{l}\text { Low, pine barrens; soil dany; near swamp; exposurs } \\
\text { froe; nnpwond } 5 \text { inches. }\end{array}$ \\
\hline $216 \ldots$ & 101 & 23 & 21 & 18 & 51 & 111 & Whistler, Ala & $\begin{array}{l}\text { Open furest, on slight decline; soil draincd; fresh; } \\
\text { exposuro free; sapwood } 4 \frac{1}{4} \text { inches. }\end{array}$ \\
\hline ....... & 110 & 22 & 22 & 12 & 68 & 109 & Gnrion, Ark... & Low, rather lense forest; wet; exposure free. \\
\hline 262. & 117 & 22 & $21 \frac{1}{2}$ & • & 69 & 116 & Eastman, Ga. & Folge of swanl, ; soil danp ; partially suppressed. \\
\hline $215 .$. & 118 & 19 & 18 & ... & 53 & 125 & Whistler, Ala & Slight declivity; soil well drained; supprensed. \\
\hline 263. & 120 & 22 & $22 \pi$ & .. & 68 & 99 & Eastman, Ga. & Noar border of gwamp; soil damp; expoenre free. \\
\hline 2 it & 128 & 23 & 221 & ... & 39 & 109 & Whistler, Ala & Open forest; soil fresh; exposure freo \\
\hline & 137 & 19 & & & 57 & 115 & Cullman, Ala & Ofieu forest; danı swale; exposure free. \\
\hline 213 & 142 & 27 & 286 & & 54 & 103 & $\ldots \ldots$ & Edge of a жaml, damp to wet; exposnre almost free. \\
\hline & 150 & 21 & 23 & $15 ?$ & 58 & 108 & Gurdon, Ark & $\begin{array}{l}\text { Flat, wet, rather dense forest; exposure free; elightly } \\
\text { oppressed on the sides. }\end{array}$ \\
\hline 25. & 156 & 24 & 25 t & & 39 & 103 & Cullman, Ala. & Wet awale; sandy loam; exposure free. \\
\hline
\end{tabular}

From Table III and the corresponding diagram, based upon a considerable number of trees, it appears that the Loblolly Pine is nearly 40 feet high when twenty years old; that the length of the m.rchantable timber ( 60 feet) is attained at the age of forty; that this shaft has a basal diameter of 20 inches at the age of one hundred years, and that the age of thrifty growth is practically at an end when the tree is one lundred and ten years old. Comparing this table with those for Longleaf and Shortleaf pines, the excellence of the Loblolly becomes apparent. 
TABLE III.-Rate of growth of Loblolly Pine.

\begin{tabular}{|c|c|c|c|c|c|c|c|c|c|c|c|c|}
\hline \multirow[b]{2}{*}{ Age. } & \multirow{2}{*}{$\begin{array}{c}\text { Diameter } \\
\text { with bark } \\
\text { (breast } \\
\text { high). }\end{array}$} & \multirow{2}{*}{$\begin{array}{l}\text { Length of } \\
\text { log with } \\
\text { apper di- } \\
\text { ameter of } \\
5 \text { inches. }\end{array}$} & \multirow{2}{*}{$\begin{array}{c}\text { Total } \\
\text { height of } \\
\text { tree. }\end{array}$} & \multicolumn{2}{|c|}{ Volume. } & \multicolumn{5}{|c|}{ Periolical aceretion or growth per decade. } & \multirow{2}{*}{$\begin{array}{c}\text { Average } \\
\text { annnal } \\
\text { accretion. }\end{array}$} & \multirow[b]{2}{*}{$\begin{array}{l}\text { Cnrrent } \\
\text { accretion. }\end{array}$} \\
\hline & & & & Tree. & $\begin{array}{l}\text { Log up to } \\
5 \text { inches } \\
\text { diameter. }\end{array}$ & Derade. & Diameter. & Height. & $\begin{array}{l}\text { Area of } \\
\text { cross sec- } \\
\text { tion. }\end{array}$ & Volume. & & \\
\hline Frs. & Inches. & Feel. & Feet. & $C u . f t$ & $C u . f t$ & Firs & Inches. & Feet. & $S q \cdot$ feet. & $C u . f t$. & Cu. $f t$. & Cu. ft. \\
\hline 20 & 5.6 & … & 37 & 3.05 & $\cdots \cdots$ & Second.... & 2.4 & 18 & 0.0 & $\begin{array}{l}0.60 \\
2.45\end{array}$ & $\begin{array}{r}0.00 \\
.14\end{array}$ & 0.00 \\
\hline 30 & 8 & 23 & 50 & 8.72 & 7.49 & Third....... & 2. & 13 & 1 & 5. & .29 & \\
\hline 40 & 10.0 & 35 & 61 & 16. 63 & I5. 45 & Fourth .............. & 2. & 11 & 1 & 7. & .41 & is \\
\hline 50 & & 44 & 70 & 25.30 & 24.12 & Fifth $\ldots \ldots \ldots$ & 1. & 9 & .1 & 8. & .57 & 87 \\
\hline 60 & 13. & 52 & 78 & 35. & 34.47 & Sixth ............. & 1. & 8 & 1 & 10. & 59 & 1.03 \\
\hline 70 & & 60 & 8 & 48 & 47.88 & Sevanth... & 1. & 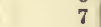 & .2 & 13. & .7 & 1.33 \\
\hline 80 & 17 & 68 & 9 & 62. & 61.44 & Eighth ....... & I. & 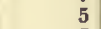 & .2 & 13. & .7 & 1.34 \\
\hline 90 & & 76 & 9. & $78 . \mathrm{C}-1$ & 77. 16 & Ninth........ & i. & 5 & .1 & & & i. \\
\hline 100 & 19. & 80 & 98 & 89. & 88.59 & Tenth ..... & .8 & 3 & .1 & 11. & .8 & 1.1 \\
\hline 110 & 20. & 83 & 10 & 96. C & 95.23 & Eleventh .... & 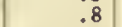 & 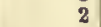 & & & 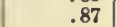 & 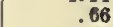 \\
\hline 120 & 20.7 & . 85 & 102 & 102.00 & 101.23 & Twelfth ...... & .5 & 2 & & 6.00 & & \\
\hline
\end{tabular}

HEIGHT

IN FEET.

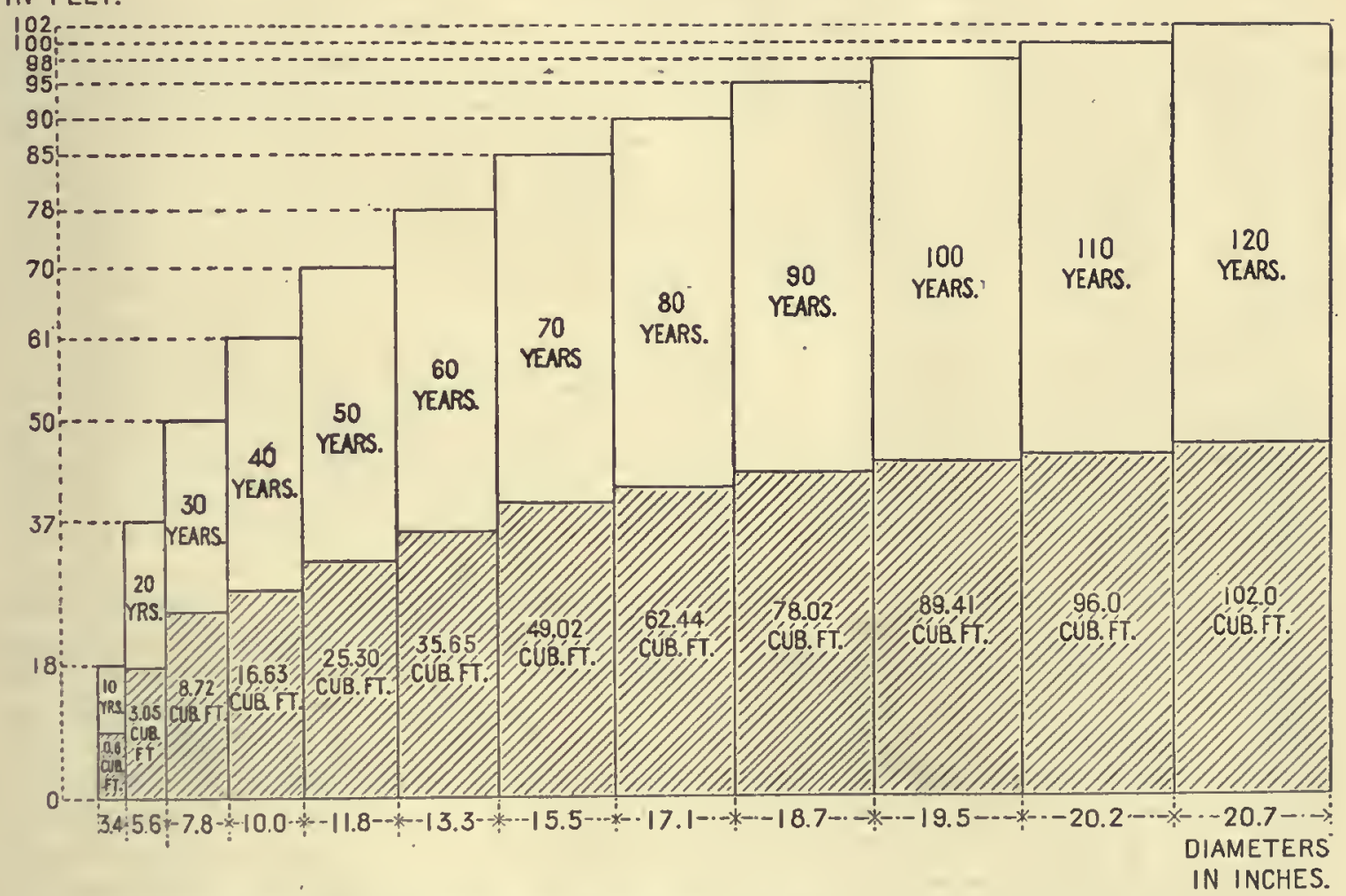

Fro. 12.-G rowth of Loblolly Pine: Height, diameter, and cubie contents of average trees at 10, 20, eto., years of age.

CONDITIONS OF DEVELOPMENT.

SOIL ANID CLIMATH.

The Loblolly Pine prefers a moist, cool, sandy or light loamy soil, whicl, if not always moist, shonld have a greater retentiveness for moisture than is required by most of the other upland pines. It reaches its greatest perfectiou in the perpetually moist or fresh forest lands, witl a soil of a sandy loam, rich in vegetable mold-the accumulation of ages-which border the swamps of the coast region. The tree is not found ou the porous, lighly siliceous soils of the more clevated uplands, where the Longleaf Pine almost exclusivcly prevails; it also avoids heavy clay and calcareous soils of the uplands and the alluvial lands.

The Isoblolly Pine is a tree of austral regions confined to the humid belt of the Austro-riparian or Louisiana zone and the lower border of the Carolinian life zone, which, on the Atlantic Coast, 7092-No. $13 \longrightarrow 9$ 
follows quite closely the isotlıermal line of $56^{\circ} \mathrm{F}$; westward, in the direetion of the Gnlf Coast, the isothermal line of $60^{\circ}$. The mean temperature of the winter along the northern limit is about $45 \circ$, with the lowest temperature only oeeasionally falling below $10^{\circ} \mathrm{F}$. This tree approaehes the Appalaehian zone only under the inflenee of a peninsular elime between the Delaware and Clresapeake bays.

The Ioblolly appears to be indifferent to the wide differenees in the amount of atmospherie preeipitation existing within the vast range of its distribution. Extending from Florida (isotherm, $\left.74^{\circ}\right)$ to the $39^{\circ}$ of nortl latitude on the Atlantic Coast (isotherm, $56^{\circ}$ ), it is found of equal thrift on the Gulf shore, with its damp air and anuual rainfall exeeeding 64 inehes, and in the flat woods of Texas, wlere the menn annual precipitation is only one-half that amount, with a mean of 6 inehes during the winter mouths. In faet, the Loblolly Pine is found most frequently and is more widely distributed in the distriets of lesser preeipitation. It is eertainly more dependent on the supplies of soil moisture than npon atmospherie humidity:

\section{RELATION TO LIGHT AND ASSOCIATED SPECIES.}

This speeies is less exaeting in its demands for direet sunlight than the kindred speeies within its range. To this relation may be aseribed the sueeess whieh it aehieves in the struggle for the possession of the soil with the Shortleaf Pine. Observing this eontest as it is going on between the eompeting speeies in the forest, the eonditions of the soil being equally favorable, the Loblolly Pine, under the eover of shade, outstrips the Shortleaf Pine under the same eonditions; and, on the other hand, where the sunlight has had uuhindered aceess, it gives way to its competitor, being then subjeeted to the disadvantage resulting from a speedier desiceation of the soil. Through sueh influences it is that, under conditions seemingly equally favorable to either one of these pines, now the one and now the other is found to predominate.

In the deep forests eovering the rich swampy lands of the eoast regions, the Loblolly Pine forms eomparatively a small part of the rich and varied growth consisting ehiefly of deeiduons trees, Blaek Gum, Sweet or Red Gum, Water Oak, and Mockernut, to which in the lower South the Magnolia, Sweet Bay, Red Bay, and Cuban Pine are to be added. Although requiring less sunlight than most pines, in the gloomy impenetrable shade of these dense forests the progeny of the Loblolly Pine has 110 future, espeeially as these lands onee eleared are devoted to tillage, being of great agricultural value.

On the lands of a poorer, more exposed soil in the maritime plain of the southern Atlantie States, in Virginia and North Carolina, and in sonthwestern Texas, this pine forms more or less compaet forests. In these forests the tree is always succeeled by its own progeny, eitler in the course of nature or after the artifieial removal of the original forest growth. On the eoast of Georgia, in Florida, and in the coast plain of the enstern Gulf States, the Ioblolly Pine is scattered among tlre Cuban and the Longleaf Pine; there its second growth meets a formidable competitor in the first named of these speeies. In the flat woods, deprived of drainage, the Cuban Pine is always found to vastly outnumber the Loblolly among the young forest growth. In the upper part of the great maritime pine belt the Loblolly Pine is frequently found annong the mixed growth of Magnolia, Spanish, Red, Post, and Blaekjack oaks, Moekernut and Pignut Hiekory, Shortleaf Pine, and Southern Spruce Pine. Throughout this region the tree takes almost undisputed possession of the old fields.

In the interior, on the uplands of oaks and Shortleaf Pine, the Loblolly is sure to gain the upper hand and to retain its hold anong the young forest growtl, giving way to its most aggressive competitor, the Shortleaf Pine, only when under the disadvantage of a greater exposure and a greater laek of moisture in the soil.

\section{ENEMIES.}

Prineipally eonfined to low, damp localities, not easily liable to invasion by the frequent conflagrations whieh seour the Southern pine forests, the Isoblolly Pine suffers less from destruetion by fire than any other speeies. In virtue of the inherent facilities for its natural renewal resulting from its feeundity and from the rapidity of its development from the earliest stages of growth, any damages inflieted by that ageney are more easily repaired. The same eauses afford it also 
greater protection against incursions of live stock. As also observed in the Shortleaf Pine, the rapidly growing seedlings form, after a few years, thickets of such density as to be avoided by the larger quadrupeds, and by the time such thickets, iu the course of natural thinning ont have become more open, the trees have reached dimeusions which place them beyond the danger of being tramped down or otherwise injured by live stock. The rapid spread and thrift of the second growth, unprotected aud uncared for, observed everywliere within the range of the distribution of tilis pine, are witnesses to its greater immunity from such dangers.

Owing to the large amount of sapwood, the timber of the Loblolly is more liable to the attacks of fungi and to the ravages of insects. The mycelium (spawn) of large polyporous fnngi is found frequently infesting the woody tissue of the living tree, the hyphe (filaments) of the spawn destroying the walls of the wood cells, causing the wood to assume a reddish color and rendering it brittle in the same way as is observed in the living Longleaf Piue timber affected with the disease called "red heart." It se'ms that the destruction caused by this disease in the Loblolly Pine is frow the start more rapid in conseqnence of the larger proportions of sapwood, and perhaps also on acconnt of the broader bands of soft springwood naturally accompauying wood of rapid growth.

In a piece of wood examined in north Alabama, the filaments of the spawn of one of these fuugi crossing each other in every direction were found to form a dense film interposed between the spring and summer wood, causing its easy separation iu the direction of the concentric rings, and, as the destruction of the wood proceeds, forming finally a compact layer of the nature of amadou, or tiuder. In the longitudiual section the rays were found full of cavities, caused by the breaking dowu of the cell walls, aud these cavities were filled with the white film of these filameuts, which similarly affected the adjoining tracheids of the resinous summerwood.

The felled timber left ou the ground is soon infested by a host of fuugi of the genera Agaricus, Trametes, Lentinus, Polyporus, and others, the uearer identification of which has not beell undertaken.

From the very limited observations that have been made it clearly appears that this pine suffers equally as much, if not more thau the other piues of Southern growth from insect enemies of various kinds. The larvie of the same capricorn beetles (Cerambycida) burrow in the body of the timber. Those of the round-headed borers (Chalcophora) dig their channels in the sapwood, as is indicated by the occurrence of several species of jumping beetles (Buprestida) which are found clinging to the leaves and branches of this tree. The nnost fatal injury it sustains is caused by the bark borers (Tomicidox); this pest particularly affecting the trees during the formation of the last cambium layer iu the later summer months. Trees felled in August are immediately infested by multitudes of these destroyers. Favored by a high temperature and an abundance of nonrishnent, several generations of them succeed each other before the close of the season, the countless broods soon infesting every tree in the vicinity and carrying their work of destruction over the full expanse of the young forest growth. Under this affliction the forests often present, by their drooping rusty-colored foliage, a sad picture of disease and decay. Weevils (Curculionidle) deposit their eggs in the youngest tender shoots; the larve which hatch from them eat their way into these shoots, causing their decay, and thus destroy the symmetry of the tree and impair the usefulness of the resulting timber. Other species of the same family puncture the older branches, lay their eggs in the exuded resin, their larve injuring the tree in a similar way. The larve of spittle insects injure the terminal buds, which are also found infested by the larva of Pitch-moths (Retinia), causing them to wither. The foliage seems to be less frequently attacked by sawflies (Lophyrus) than the tender young leaves of the Longleaf Pine, as by the rapidity of their growth the young leaves sooner harden, and arc therefore less relished by these depredators. The evidences of the work of the pine-leaf miners (caterpillar of Gelechia) have been freequently observed in Alabama, and everywhere are seen the deformities caused by gall flies and seale insects.

\section{NATURAL REPRODUCTION.}

If the Shortleaf Pine has been spoken of emphatically as the future timber tree of the light rolling uplands of the iuterior, the Loblolly Pine might be fitly desiguated as the timber tree of greatest promise in a large part of the coast plain from the middle Atlantic States to the limits of compact forest growth beyond the Mississippi River. The promptness with which it colonizes the 
old fields and other elearings, and the tenacity with whieh it retains from one generation to another the ground onee taken possession of, elearly point to the important part this tree is to take when tho ruthless stripping of timber lands praetieed at present gives plaee to the management of the forests under a system of fostering eare, teuding to thcir future maintenance and to the disposal of their resourecs on the principle of true cconomy with an eye to the future welfare of the eountry. No timber tree will be fonnd better adapted for forest planting in the southern part of the Atlantic forest division. It is only in the narrow belt of flat woods along the shores of Florida, Georgia, and the castern Gulf region that it is likely to find its snpcrior in the Cuban Pine (Pinus heterophylla).

Besides the advantages of adaptability to varied soil and elimate, it cxecls in rapidity of growth during the earliest stages, and the eopious production of sceds, which, almost without fail, are plentifully distributed every year over the vicinity of the parent trees. As an evidence of the facility with which the reproduction of a compact forest by this pine is effected, it is only neeessary to point out the spontaneons groves near the settlements, representing, as they do, every stage of development.

In the coast region the second growth, if not interfered with under proper soil conditions, yields in fifty to sixty years timber of dimensions rendering it fit to be sawn into lumber well adapted for various uses, as already mentioned.

\section{CONCLUSION.}

In this attempt at a sketch of the life history of this tree, the objeet was eonstantly kept in view of placing its value among the products of the Southern forests in the proper light. From the consideration of the strueture of the wood and its physical properties it elearly appears that although inferior to the wood of the Longleaf and Cuban pines, the timber of this species fully equals that of Shortleaf Pine, and that the present praetice of treating them as equivalent scens therefore justified.

As an abundant and cheap source of timber of inferior grades, and espeeially when the rapidity of its growth is eonsidered, the Loblolly Pine is of no less economie importance than the other timber trees of the same seetion. At present held in low esteem in the great lumbering distriets of the lower South, where the supplies of the superior timber of the Longleaf Pine still abound and reeeive the preference, the value of the timber of the Loblolly Pine is quiekly reeognized in other distriets which, but a short while ago boasting of similar resources, are now stripped of them. Its physiologieal peculiarities make it au important factor iu the future forestry of this scction. Its propagation is successful over a vast expanse in the southern seetion of the Atlantie forest region, and by its productive eapaeities, mode of development, and behavior toward eompetiug speeies in the strnggle for existenee, the Loblolly Pine possesses great advantages for its latural and artificial renewal, adapting it particularly for the restoration of the forests on the lowlands of the maritime region. 


\title{
ADDITIONAL NOTES ON LOBLOLLY PINE.
}

\author{
By Filibert Roth.
}

(September 1, 1897.)

Where Loblolly is the great timber tree of the woods, and often by itself covers many miles of land, in the northeast part of North Carolina, this tree is nniversally known as "Shortleaf Pine." Many people employ special names for yonng growth or saplings of nnusnal developincnt, especially where the connection between the matnre tree and the sapling is not quite clear to them. In Florida the tree is often little known, and is usually gronped with Pond Pine as "Loblolly." In Texas the name "Bastard" pine is freqnently employed, implying a belief that this is a hybrid between the Longleaf and Shortleaf pines.

In the large forests of North Carolina, east of the Wilmington and Weldon Railroad, where this tree seems at its best, and where it furnishes 80 to 85 per ecnt of the Nortl Carolina pine of the market, it is always a fast grower and a heavy bearer. At its sonthern limits in the peninsula of Florida the species ocenrs only in hammock lands and similar sites, wherc it nevertheless still makes large trecs.

Saplings 10 to 15 feet high aloug the edges of clearings are often laden with cones and rapidly secd the open ground for many rods abont. In this old-settled region, where the danger from fire is limited, dense groves of saplings are met on every hand and millions of fcet of lnmber are to-day cut from land where the corn rows are still apparent. It is probably fair to say that the average lumber-size trce of this region is not over one hnndred and twenty-five ycars old, and thousands of them are less than eighty years. Nnmerons tracts are now cut for the second time in thirty years, a fact which has misled many men to cnunciate the absnrd statement that this pine required only fifteen to thirty years to grow to merchantable size. Generally the logging is not clean, and in most cases a fine lot of pole trees is left 8 to 12 inches in diameter, requiring only a further increase of 4 to 8 inches to become of lumber size.

In the North Carolina district (including sontheast Virginia) this pine is distinctly a "sap pine," more than 70 per cent of the wood being sapwood. In logging the stem is cut into standard sizes, the top is entirely rejected, and the logs are rafted or else hanled to the mill by railway. It is usually sawn with band saws, almost exclnsively into boards $1 \frac{1}{2}$ inches or less, and at once dried in dry kilns at temperatures of $160^{\circ}$ to $180^{\circ} \mathrm{F}$. Equipment and method as well as the product tnrned ont by the larger establishments of this district are unexcelled in the mannfactnre of lumber in this country.

Close to the principal markets, on cheap land, and stocked with the fastest-growing and best reproducing pine in this country, these forests have a very bright futnre. With a reasonable amonnt of care, well-paying pine forests, yielding 30,000 to 50,000 feet of good pine per acre in one hundred years may be established here. 



\section{THE SPRUCE PINE.}

(PINUS GLABRA Walt.)

HISTORICAL.

Distribution.

ECONOMIC Importance.

Botanical Description.

Progress of DhVelopment.

Enemies.

Requirements of Development. 


\section{THE SPIRUCE. PINE.}

(Dinus glabra Walt.)

Synonyms: Pinus ylubra Walter, Fl. Caroliniana, 237 (1788).

Pinus mitis $\beta$ ? paupera Wood, Cl. Book, 660 (1869).

\section{COMMION OR LOCAL NAMES.}

Spruce Pine (S. C., Ala., Fla.).

Cedar l'ine (Miss.).

White Pine (Fla.).
Walter's l'ine (S. C.).

Lowlanal Spruce l'ine (Fla.).

Poor Pino (Fla.). 


\title{
THE SPRUCE PINE.
}

\author{
By Charles Mohr, Ph. D.
}

INTRODUCTORY.

The Spruce Pine is the least common of the pines found in the lower Southern States. The tree is frequeutly confounded by the inhabitants with the Shortlcaf Pine, to which it is closcly related. Its vernacular names are, in different sections of its range, applied to several other pines; in Florida to the Sand Pine (Pinus clausa), in north Alabama to the Scrub Pine (P'inus rirginiana), and in the southem part of this State even to the Cuban Pine. Although never forming cxtensive borlies of timber, beiug for the most part widely seattercd among the broadleaf evergreens and deridnous trees with which it is associated, and iu. the quality of its wood of low rank, this little known tree has been given a place here among the monographs of the timber pines of the South Atlautic forest regiou in order to dispel for the future its confusion with some of these trees, and at the same time to attract the attention of the tree planter to it as the only one of its kind wlich thrives and propagates in the shade, keeping its ground closely surrounded by the luxuriant and varicl tree growth with which it is associated, and soon outstripping the same by the rapidity of its growth. Considering that among all other's of its kind in the same region it attains the fullucss of its growth in the shortest time, with dimensions which render it valuable for many of the purposes for which the softer aud lighter kinds of timber are used, its economic importance can not be ignorcd.

\section{HISTORICAL.}

The Sprucc I'ine was first recognized as a distinct species and described as Pinus glabra by Walter, in his Flora Caroliniana in 1788, laving since that time been knowu under this name by the lotanists. Hidden iu the remote semiswampy dense forests, it escuped the attention of later botanists. Neither the Michauxs, father and son, nor Nuttall were aware of its existence. It was unkwown for fully three-fourths of a century until rediscovered by Professor Ravenel in the swamps of Berkelcy County, S. C. Ten years later the trec was described in Chapman's Flora, 1860. It was recognized by Professor Hilgard in the Pearl River Valley, Mississipui, In 1880 its distribution was traced by the writer through tlre Gulf region to its western limit in the eastern parishes of Louisiana.

\section{DISTRIBUTION.}

The Sprnce Pine is a tree of the southeastcrn Atlantic forest, confined to the subtropical region or the Louisianian zone of Ameriean botanists, within that part of the coastal plain of the southern Atlantic and the Gulf States embraced between the thirty-first and thirty-third degrees of north latitnde; from South Garolina through iniddle and northwestern Florida to Louisiana, with its western limit between the Pearl and Mississippi rivers. This tree is mostly found single or in groups on the low terraces with a fresh or damp soil rich in humus, rising above the swamps subject to frequent overflow. It is seldom secn to form compact bodies of timber; snch have only beelı observed between the Chattahoochce and Choctawhatchee rivers, in north western Florida, where, to all appearances, this tree finds its best devclopment on isolated tracts of fertile red loam lands.

\section{ECONOMIC IMPORTANCE.}

Nowhere forming pure forests of any extent, this pine is of little inportance to the lumberiug interests of the present, and its timber has never become an article of commerce. Although the timber is of inferior quality, it furnishes lumber of dimensions equaling the best of our timber 
pines. It is light, soft, easily worked, and capable of good finish, and is withont doubt fit for many uses of the house carpenter and cabinetmaker in the manufacture of furniture and other purposes. Owing to the large percentage of ash and suller quantity of resinous matter, the actual fuel valne of the wood of the Spruce Pine is lower than that of the other Southern pines; for its resinous produet the tree is considered of no value, since the resin does not run when it is tapped.'

In its wood the Spruce Pine resembles Loblolly. The sapwood is wide, and even in trees seventy-five to eighty years old it forus more than three-fourths of all the wood. The clinge from sap to heart wood begins as early as in the pines mentioned, and as in these is retarled with. age and also with any suppression of growth, so that iu stunted young trees the change begins" later, and the sapwood of these, as well as old trees, is always composed of a greater number of riugs. While green, the wood is very heavy, weighing 45 to 50 pounds per eubic foot, varying in this respect chiefly with the proportion of sapwood. When kiln-dried, the wood weighs about 27 pounds to the eubic foot; it is heavier at the butt, weighing about 31 ponnds to the cubic foot, and lightest near the top, where its weight falls as low as 25 pounds to the cubic foot. As in other pines, the heaviest wood is prodnced by young trees. The amount of water contained in the fresh wood is quite variable-very great in the sapwood, and conseqnently iu young timber-but falls little below 50 per cent of the weight of green timber on the whole. Its beliavior in drying is the same as in light grades of Loblolly; it dries rapidly and without much injury, shrinkiug, duriug this process, by about 10 per ceut of its volume.

The strength of this wood is, as in other conifers, closely related to its weight. Accordingly, the Spruce Pine is inferior to both Shortleaf aud Loblolly.

From careful experiment it appears that its-

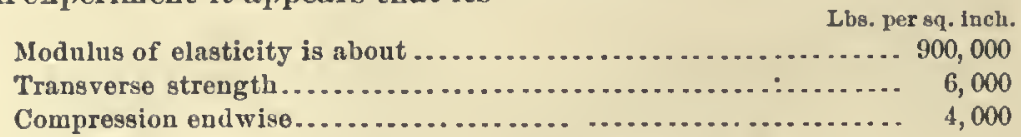

In its structure the wood resembles too closely that of the Loblolly to enable as yet any identification on this feature, and the deseription for the wood of the Loblolly answers perfectly for the product of this species. As in Loblolly and other lıard pines, summerwool and springwood are always well defined, the summerwood forming from 15 up to 40 per eent of the total volume, differing in this respect from the White Pine which it has been claimed to resemble. Thus while decidedly softer on the whole thau Loblolly it is by no means to be expected that the Spruce P'ine eau hope to serve as a geueral substitute for the trne White Pine.

\section{BOTANICAL DESCRIPTION.}

Leaves invariably in pairs, with short and elose sheath; soft, slender, $1 \frac{1}{2}$ to 3 inches long, twisted; cones short-stalked, horizontal or reflexed, the cone seales with a flat apophysis, the depressed umbo unarmed or with a minute weak erect prickle.

The Spruce Pine is readily distinguished by the elose bark of its trnuk which in the crown and the linbs is perfectly smooth and of a light gray color; in foliage and in cones it resembles most closely the Sand Pine (Pinus clausa) of the coast region of Florida and the eastern Gulf States, which however is distinguished by the more prominent apophysis of the cone scales, armed witl a short, stout, reflexed prickle. The Shortleaf Pine, to which it is next related, is distinguished by the same characters and further by the fascicles of two and three leaves and the rigid young shoots of the season eovered with slender, long, loosely fimbriated bud scales.

The leaves are concave, faintly serrulate, short pointed, and are shed during the latter part of the secoud season or the beginuing of the third.

In the details of their structure they differ little from the leaves of the Shortleaf Pine; the rows of breathiug pores (stomata) are uumerous on both surfaces; the strengthening cells of the cortical tissue are smaller and less numerous; the resin ducts, two or three, are parenchymatons, the cells of the bundle sheath thin walled. The two fibro-vascular buudles distaut and without strengthening cells.

${ }^{1}$ Ravenel: Proceerl. of Elliott Socicty, Charleston, I, 52. 
The male flowers are lateral, sessile, and about onc-half to three-fourths of an inch long, slender, surrounded by five to six pairs of short ovate, rather obtuse stiff scales, with a narrow, membranaceous lacerated border. The crest of the anther is elliptical, with fine dentieulations. The small female aments are mostly single, short stalked, the carpellary scales lance-shaped with slender tips and subtended by the slort infertile bract.

The cones are mostly single with a short stalk and of various shapes on the same tree, from round to oblong ovate or more or less cone-shaped, from $1 \frac{1}{4}$ to 2 inches long, and, on the opening of the scales from three-fourths to one inch wide, of a light tawny color. The scales are softer and more flexible than in the Shortleaf Pine, the apophysis broader, with the nmbo depressed, unarmed, or with a minute, weak, erect, and dcciduous prickle, the ridge faint, hazel-brown on the insidc. The somewhat triangular roughish seeds, black with brown specks, about threesixteenths of an inch long and one-eighth inch widc, separating easily from the wing which is little over one-half inch long and surrounds the seed to the base.

\section{PROGRESS OF DEVELOPMENT.}

The Spruce Pine begins to flower and to produce perfect seeds at an age of twelve to fifteen years, in greatest abundance between twenty and forty years; the flowers appear during the earliest part of March; shortly after pollination the female aments assume a horizontal position, and finally become more or less reflected. At the cnd of the first season the conelets are of the size of a large pea. The cones mature iu the second year in the month of September; the seeds are freely shed early in the fall. They germinate during the fall and early in the coming spring; the plantlets, with eight to ten slender, soft cotyledons, are over an inch long. The terminal bud develops rapidly, densely covered with the slender, soft primary leaves which are sharp pointed and frequently over an inch in length. Early in April seedlings are found over one-half foot long, later in the season fascicles of the foliage lcaves appcar in the axils of the upper primary leaves, when the lower wither and disappcar near the end of the season. At this stage the seedlings are generally a foot high with the root system less developed than in its kindred species at the same age; the taproot scarcely 2 inches in length with a few short lateral roots.

With the twentieth year the trces are generally from 30 to 35 feet high and 4 to $4 \frac{1}{2}$ inches in diameter, the stem clear of limbs for the length of about 12 feet. They attain their full growth at an age of from sixty to scventy-five years.

The trees for the United States timber tests from the border of the swamps on the banks of the Tensaw River in Baldwin County, Ala., showed the following dimensions and age:

Measurements of five trees.

\begin{tabular}{|c|c|c|c|c|c|}
\hline No. of tree. & $\begin{array}{l}\text { Rings on } \\
\text { stump. }\end{array}$ & $\begin{array}{c}\text { Diameter } \\
\text { breast high. }\end{array}$ & $\begin{array}{l}\text { Length of } \\
\text { timber. }\end{array}$ & $\begin{array}{l}\text { Height of } \\
\text { tree. }\end{array}$ & $\begin{array}{l}\text { Sap on } \\
\text { radius. }\end{array}$ \\
\hline $\begin{array}{l}458 \\
459 \\
460 \\
461\end{array}$ & $\begin{array}{l}78 \\
53 \\
46 \\
75 \\
83\end{array}$ & $\begin{array}{r}\text { Inches. } \\
22 \\
17 \\
15 \\
22 \\
23\end{array}$ & $\begin{array}{r}\text { Feet. } \\
45 \\
56 \\
40 \\
57 \\
60\end{array}$ & $\begin{array}{r}\text { Feet. } \\
120 \\
96 \\
85 \\
99 \\
116\end{array}$ & $\begin{array}{r}5.7 \\
511 \\
5 \\
5 \\
5\end{array}$ \\
\hline
\end{tabular}

Froin these figures it appears that the two trees forty-six and fifty-threc (average forty-nine) ycars old have an avcrage volume of 63 cubic feet and grew at the rate of about 1.3 cubic fcet, while the three trees seventy-five to eighty-three (average seventy-eight) years old have an average volume of about 152 cubic fcet and an average yearly growth of about 2 cubic feet. The following represents a typical case:

Growth of Spruce Pine.

\begin{tabular}{|c|c|c|c|c|c|c|}
\hline \multirow{2}{*}{$\begin{array}{l}\text { Rings on } \\
\text { stump. } a\end{array}$} & \multirow{2}{*}{$\begin{array}{c}\text { Heigbt of } \\
\text { tree. }\end{array}$} & \multirow{2}{*}{$\begin{array}{l}\text { Diamoter } \\
\text { without } \\
\text { bark. }\end{array}$} & \multirow{2}{*}{$\begin{array}{l}\text { Volume of } \\
\text { wood. }\end{array}$} & \multicolumn{3}{|c|}{ Arerage yearly growth in- } \\
\hline & & & & Height. & Diameter. & Volumo. \\
\hline $\begin{array}{l}10 \\
20 \\
30 \\
45\end{array}$ & $\begin{array}{r}\text { Feet. } \\
37 \\
51 \\
67 \\
84\end{array}$ & $\begin{array}{c}\text { Inches. } \\
5 \\
8.5 \\
12 \\
15\end{array}$ & $\begin{array}{r}\text { Culvic ft. } \\
2.5 \\
9.5 \\
26 \\
51\end{array}$ & $\begin{array}{r}\text { Feet. } \\
3.7 \\
1.4 \\
1.6 \\
1.1\end{array}$ & $\begin{array}{r}\text { Inches. } \\
0.5 \\
.3 \\
.3 \\
.2\end{array}$ & $\begin{array}{r}\text { Cubicft. } \\
0.2 \\
.7 \\
1.6 \\
1.6\end{array}$ \\
\hline
\end{tabular}

a For age of tree add about three yeare. 
The Spruce Pine attains a lieiglit of from 85 to 110 feet and over; the trunk is elear of limbs for a length of from 45 to 60 feet, and it is from 2 to $2 \frac{1}{2}$ feet in diameter breast ligh, seldom exceeding 3 feet. The largest trees observed were about 120 feet in height by a girth of fuily 10 feet breast high.

The taproot appears to be less strongly developed than in the Shortleaf, the lower lateral roots run for a short distanee elose to the surfaee before penetrating the gronnd; the bark is elose, with lecp, narrow furrows, separating in narrow thin seales and of areddish-browu color. The limbs are horizontul, dividing in reetangular spreading branelies and branehlets. The leaves also become in the latter part of the senson widely spreading, the density of the foliage being reenforeed by the leaves of the sliort brauchlets produeed on the older branehes from adventitious buds. To this spreadiug, habit of the ultimate division of the branehes and of the leaves is due the peculiar spray of the foliage, similar to that of the true eedars.

\section{ENEMIES.}

No observations have been made of the iujuries inflicted upon this tree by inseets. Trees, after having passed the period of full growth, at the age of about 100 years are very frequeutly affeeted with decay in the stump and with redheart in the top. In the damp hummock lands the tree is rarely touched by fire. Where the underbrush and the vegctable matter of the soil covering has beell destroyed by repeated eonflagratious, however, the trees begin to sieken and soou die.

\section{REQUIREMENTS OF DEVELOPMENT.}

The Spruee Pine requires the warm elinate of the subtropical zone, with a mean annual temperature of about $66^{\circ} \mathrm{F}$. and a mean tcinperature of $49^{\circ} \mathrm{F}$. in the winter inonths (in eeutral Alabama the thermometer falls sometimes to an extreme of $5^{\circ} \mathrm{F}$.), and the humid atmosphere of the coastal plain, with a mean annual rainfall of 54 inehes, evenly distributed throughout the year. This tree will endure, during the early stages of its growth, more shade thau any other of the piues of the Atlantie forest region, perhaps the White Pine (Pinus strobus) exeepted. Retarded in its grow th under severe oppression, it will finally foree its way through its elose surronudings, and laving gained a freer aeeess to light, it pushes its crown rapidly above the broad-leaved evergreens and deciduons trees whieh luxuriate on the same ground. It demands a loose soil, rich in liumus, fresh to moist but not wet, with a deep porous subsoil, which in these lands is frequently a light, sandy loam.

The Spruee Pine is uever found in the forest of the alluvial hottoms with their heavy soil, sub. jeet to frequent overflow, nor in the dry, sandy pine forests. Where it finds the soil conditious most favorable to its growth, Magnolias, Cueunber trees, Sweet Gum, Moekeruut Hiekory, and Beech are found of greatest thrift, uot infrequently assoeiated with the Shortleaf and the Loblolly pines. The undergrowth on sueh lands is luxuriant, eousisting of Dogwood, Holly, Summer Haw, and a variety of shrubs, Bush Huckleberries (Vaccinium rirgatum), Farkleberries (V. arboreum), Storax Bushes (Styrax grandifolium), Cornels (Cornus sericea), and Blne Palmetto, formiug dense brush iuterlaced by numerous woody elimbers (Vitis, Ampelopsis, Wistaria).

As has beeu observed in northwestern Florida, where it fiuds the proper soil eonditions, the second growth of this pine soou oceupies the eleariugs made in the original forest. Traets of young forcsts of inueh promise have been met with between the Choetawhatehee and Chattahooehee rivers. The hammoek laud, forming the home of the Spruce Pine, being with the iuerease of the population rapidly elaimed for eultivatiou, this beautiful pine will soon be solely eonfined to the most remote and inaceessible loealities. Being the only really soft pine of the Sonthern States, and having by its shade enduranee a peenliar forest value, this tree will probably form an important part in the future, when forestry has beeome an established business. 


\section{NOTES ON THE STRUCTURE OF THE WOOD OF FIVE SOUTHERN PINES.}

(Pinus palnstris, heterophylla, echinata, tada, glabra.)

SAP AND Heartwood.

ANNual Rivgs.

SPRING AND SUMMER WOOD.

Grain of THE WoOD.

Minute Anatomy. 



\title{
NOTES ON THE STRUCTURE OF THE WOOD OF FIVE SOUTHERN PINES.
}

\author{
(Pinus palustris, heterophylla, echinata, toda, glabra.) \\ By Filibert Roth, \\ In charge of Timber Physics, Division of Forestry.
}

The wood of these pines is so much alike in appearance and even in minute structure that it can be discussed largely without distinction of species. The distinctions, as far as there are any, have been pointed out in the introduction. Here it is proposed to give in more detail the characteristics of the wood structure.

\section{SAP AND HEARTWOOD.}

All five species have a distinet sap and heartwood, the sap being light yellow to whitish, the heart yellowish to reddisli or orange brown. The line of demareation between the two is well defined, witlout any visible transition stage. The location of this line does not as a rule coincide with the line of any annual ring, so that the wood of the same year's growth may be sap on one side of the tree and heart on the other. The difference in this condition may amount to ten or twenty rings, which on one side of the same section will be heart, on the other side sap.

There is considerable variation in the relative width of the two zones as well as the number of rings involved in either and also in the age at which the transition from sap to heartwood begins. This age was rarely found to be below twenty years; as a rule the transformation begius in young trees when the particular section of the tree is between twenty and twenty-five years old, but the progress of heart formation does not keep pace with the annual growth, being more and more retarded as the tree grows older, so that while in a section twenty-five years old twenty-two rings may be sapwood, at thirty-five years the sapwood will comprise only thirty rings; at forty-five years, forty rings; at eighty years, fifty rings; and in sections two hundred years old the outer eighty to olle hundred rings will still be sap. A young tree of Longleaf Pine (No. 22) was, for instance, found to show the following relations:

\begin{tabular}{|c|c|c|c|}
\hline Section. & $\begin{array}{l}\text { Height } \\
\text { from } \\
\text { stump. }\end{array}$ & $\begin{array}{c}\text { Age of } \\
\text { section. }\end{array}$ & $\begin{array}{c}\text { Rings of } \\
\text { Bap. }\end{array}$ \\
\hline $\begin{array}{l}\operatorname{II} \ldots \ldots . \\
\operatorname{IV} \ldots \ldots . \\
\operatorname{VIX} \ldots \ldots . \\
\text { XII....... }\end{array}$ & $\begin{array}{r}\text { Feet. } \\
6 \\
14 \\
22 \\
30 \\
42\end{array}$ & $\begin{array}{r}\text { Tears. } \\
46 \\
38 \\
30 \\
24 \\
18\end{array}$ & $\begin{array}{r}\text { Number. } \\
40 \\
33 \\
27 \\
23 \\
17\end{array}$ \\
\hline
\end{tabular}

The change from sap to heart wood begins earlier in young trees than in the younger portions of older trees; in these latter, scetions thirty-six and forty years old are quite commonly found still entirely made up of sapwood, while in young trees, as stated above, the change begins before the age of thirty years.

The progress of the transformation is somewhat influenced by the rate of growth; it is slower in slow-growing trees and usually also on the slower-growing radius, i. e., there are more rings of 
sapwood. The widtly of the sapwood, ou the other liand, stauds in relation to the rate of growth in an cpposite manner; it is wider in young and thrifty than in old and stunted trees, and widest along the greatest radins of any section; similarly, it is wider in the faster.growing Loblolly, Cuban, and Spruce pines than in the slow-growing Longleaf.

liesides being of a lighter color the sapwood differs from the heirtwood in several respeets. Its resin is limpid and oozes out of the pores or resin ducts of any fresh cut; that of the lieartwood loes not flaw, except in rare cases, from saturated pieces or "light wood." The sapwood contains inuclı less resin-both rosin and turpentine - than the heart wood. Thus in a section of Longleaf the-sapwood eontained only 0.2 per cent of turpentine and 1 per cent of rosin, while the heart contained from 2 to 4 per eent of turpentine and 12 to 24 per cent of rosin, and though this is an extreme case the lieart generally has three to five times as much resinous matter as the sap. The fresh sapwood contains three to five times as much free water as the heartwood and is, even when seasoned, mole hygroscopic and subject to relatively greater slırinkage than the heart. Tlis capacity for taking ul water readily is probably one of the reasons why sapwood decays more readily. In addition, the parenchyma cells of the medullary rays and resin ducts (see further on) contain, at least in the outer parts of the sapwood, living protoplasm and reserve food materials which are readily seized upon by fungi which cause "bluing" and decay. Such living tissue does not exist in the heartwood. The heartwood in old logs generally is heavier than the sapwood. This is not due to any later thickening or growth of its cell walls, after their original formation, but is due chiefly to two causes:

1. The heartwond of old logs was formed when the tree was younger, and made, naturally, heavier wood.

2. The accumulation of resin in the heart already referred to increases often very considerably the weight of the heartwood.

In the same way the sapwood of old $\operatorname{logs}$, such as supply the sawmills, is weaker thau the lieartwood of the same logs, but this is not because the wood is in the sapwood condition, but because it is lighter and its summerwood per cent smaller, being, as stated before, the product of old age when heary and strong wood is no longer formed. Chemically the rood substance of sapiwood is practically like that of leartwood; the coloring substances which permeate the cell walls in heartwood appenr to be infiltrations, i. e., deposited in the walls from solutions; they are insignificant in amount, and their true nature, especially the processes lealing to their formation, are not yet fully understood. The most modern views which eonsider these coloring bodies or heartwood substances as products of oxidation of tamnin still require confirmation.

\section{ANNUAL RINGS.}

The layers of growth, kuowu and appearing on any cross section as annual rings, show very distinctly in the wood of these pines. Iu a section $S$ or $\mathbf{1 0}$ feet from the ground the rings are widest at the center, of considerable width for the first thirty to tifty rings, the period of most rapid grow th in height; then they grow more and more narrow toward the periphery. In the last sixty to one hundred rings of very old logs the decrease is very small, the rings remaining practically of the same width. The sane year's growth is usually wider in the upper part of the stem, botl in young and old trees, but the average width of the rings is naturally greater in the npper part only of young trees; in old and also in stunted trees it is smaller, since in these the upper portions do not share in the wore rapid growth of the early years.

Rings over half an inch wide are frequently seen in Loblolly and oecur in Spruee Pine; rings one-fourth of an inch in willth occur in very thrifty saplings of all five species, but the average width of the rings for sapling timber is usually less thau one-fourth of an inch, commonly one-eiglitl. In trees over one lundred years old it drops to one-twelfth of an inch and even below. The average width of the rings is normally smallest in Longleaf Pine, being one-twenty-fifth of an iuch and less. (See also tables and diagrams of rate of growth in the introduction, as well as in the several 111010graphs.)

The influence of orientation on the width of the rings is 'completely obscured by other, nore potent influences, so that sometimes the radius on the north side, other times that of 'some other' 
side, is the greatest; ald it is a common observation to see this relation vary within wirle linits, eveu in the trumk of the same tree.

Stunted trees of Longleaf l'ine over one hundred years old with an average width of ring of one-fiftieth of an inch are frequently met with in old timber; of the other species no such trees were observed. The decrease of the width of the rings from center to periphery is never perfectly uniforu. Not only do consecutive riugs differ within eonsiderable limits, but frequeutly zoues of narrower riugs, including thirty or more years' growth, disturb the general regularity. Where these zones cousist of very narrow riugs, one-fiftieth of au inch or less, the wood is of distinctly lighter color and weight. Since the value of this class of wood depends not only on its strength and stiffness but also on the fineness of its rings (grain), iu so far as the grain influences both the appearance and the ease of slaping as well as other mechanical properties, the width of the aunual ring is of great importanee, from a technical point of view, the finer-ringed (grained) wood of the same weight al ways deserving and mostly receiving preferenee.

The rings of the limbs are narrower than the eorresponding rings of the stem. Moreover, they are usually of different willths on the lipper and lower side of the same braneh, those of the latter exeelling in width those of the former. Frequently the wider lower part of a ring of a branch appears like a "lune" on the cross section, quite wide (one-eighth of an ineh and more) in its lower median part, and scarcely visible, often entirely fading out, on the upper side. This difference is commonly aecentuated by the appearance of the wood itself. In the upper part the wood of the ring is norual and light eolored, owing to a very small summerwood per eent; on the lower wide part, the "Iune," the wood is eommonly of reddish color, either even throughout the entire width of the ring, or else in several varicolored bands, which give the appearance of two or more separate ill-defined rings. Sometimes the earliest formed springwood is included in this unusual eoloration, at other times only the median portion of the ring. This "red wood," as it has been termed by the French and German writers, is composed of very thick walled eells and inereases markedly the weight of the wood, so that the wood of the side containing it is usually much the heaviest. It is of interest that the several "lnues" in any cross seetion occur rarely, if ever, exaetly one above the other, but commonly the radius passing through the middle of one "lune" inakes an angle of 20 to 40 degrees with the radius passing through the niddle of another "lune." Often suceessive "Innes" show considerable deviation in position and commonly differ in width or degree of development. Accepting the most rerent explanation of this phenomenon as expressed by Hartig and Cieslar, ${ }^{1}$ it would appear that the formation of these broad "lunes" of especially strong cells is due to pressure-stimulns on the growing eambium, eaused by the weight of the linb anl its peeuliar position, increased at all times by movements of the limb due to the wind. Moreover it seems that the formatiou of one well-developed "lune" relieves for a time the pressure, and with it the necessity for a repetition of this formation. These "lunes" are most conspienous in the limbs of these pines near the trunk, and disappear at variable distances from the trunk and with them disappears the ecentricity and the differeuee in appearanee and weight of the wood of the limbs. Immediately at the junction of limb and stem the pressure is constant, and the resnlt is the fornation of almost uniformly thiek-walled tissue in all parts of the ring, giving to the "knot" its great weight and harduess.

Lunes similar to those of the linb are freinently observed in the steins of small trees; wherever this lias been noted it was found on the underside of a leaning or eurved portion. ${ }^{2}$ Occasionally such a "lune" extends for 12 and more feet up and down.

Quite distinct from this modifieation of the annual ring is another modification frequently seen, especially in young trees, giving rise to so-called "false" rings. It consists in the appearance of one or more, rarely two, dark-colored lines, which precede the true summerwood band of the ring. These lines, resembliug the summerwoor in eolor and eomposed like it of thick-wallerl cells, follow the true springwood of the year and are separated from the summerwood aud from each other (if there are more than oue), by a light-colored line resembling springwood. While occusioually this is somewliat misleading iu counting the rings, a moderate magnification usually suffices to

'A. Cieslar, "Rotholy d. Fichte," Centralblate f. d. g. Forstwesen 1896, p. 149, and Robert Hartig "Das Rothholz der Fichte" in Forstlich-naturwissenschaftlicho "/citschrift, 1896, p. 165.

${ }^{2}$ Cimglar produced them at will by bending young spruce saplings.

7092-No. $13-10$ 
distingnish the real charneter of the tissnes, as deseribed later on. A more serions difticulty arises in very ald, slowly growing trees, where the ring sometimes is represented by only one to three cells (see fig. 1S) and oecisionally disappears, i. e., is entirely wanting in some parts of the eross section. Gencrally these cases, dne to various canses, are ton rare to serionsly interfere in the establishment of the age of" a tree.

\section{NIRING AND NUMMER WOOD.}

'The difference between spring and smmmer woot is strongly unitich in these pines, the transition from the former to the latter being nomally abrupt and giving to the annual ring the nplpearanee of two sharply defined bands. (See figs. 13 and $18 \mathrm{~B}$.) In wide lings the transition is "simetimes gradual. 'The springwoul is light colored, has a specifie gravity of alont 0.40, and thus weighs somewhat less than lanlf as much as the darker summerwood, with a spreeific gravity of alyont 0.90 to $1.0 \%$, so that the weiglet and with it the strength of the wood is greater, the larger the anomut of snmmerwoerl. (See diagram, fig. 14.)

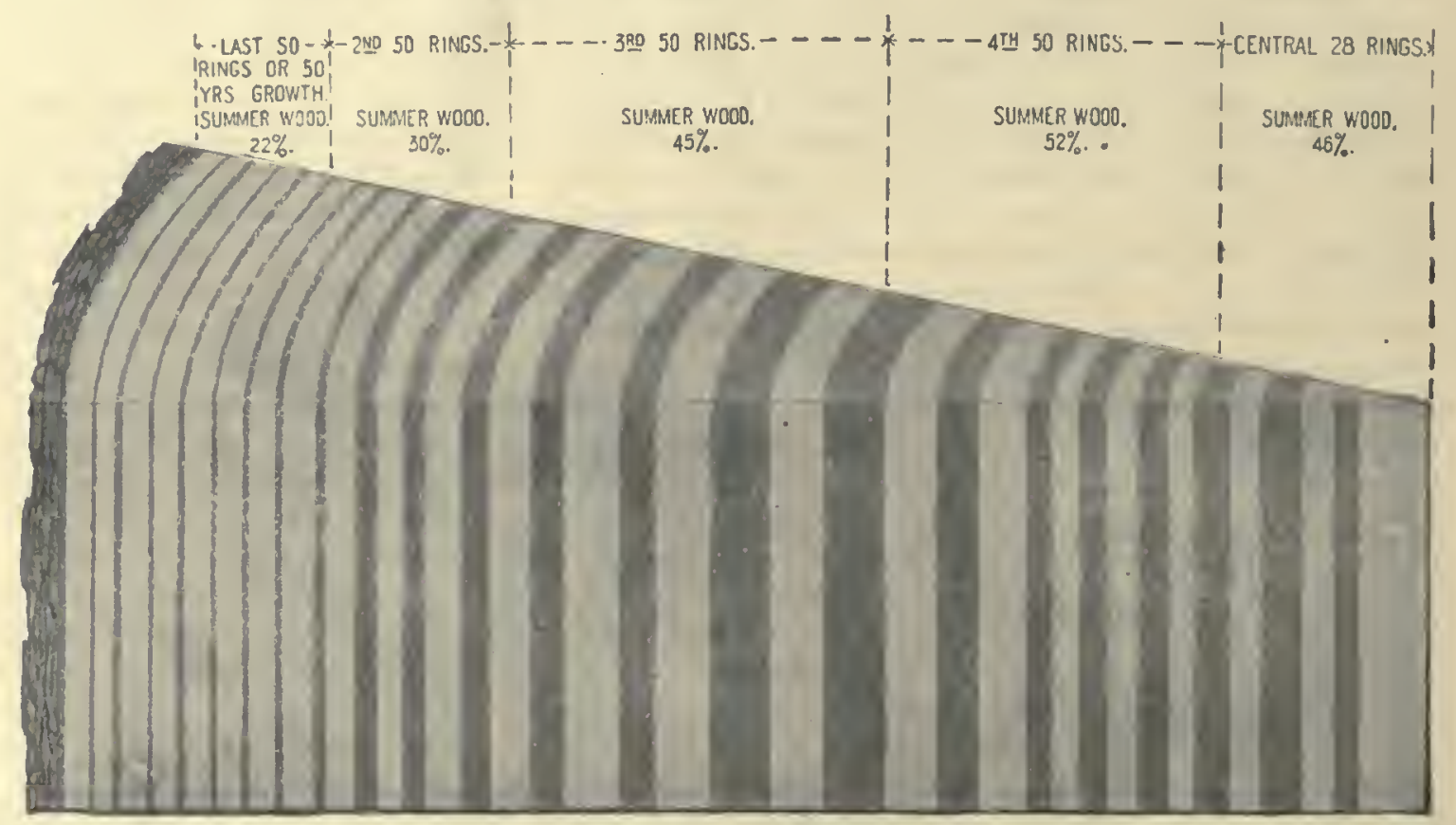

Fro. 13.- Variation of summerwnd per cent frum pith to bark.

The absolnte wilth of the snmmerwoul varies generally with the wilth of the ring (see diagram, fig. 15), i. e., the wider the ring the wider the smmmerwood hand. It decreases in a cross section of an old $\log$ from near the pith to the periphery, and in the same layer, from the stmmp) to the top of the tree. Where the growtl of the stem is very ercentric, the wood along the greater radins has the greatest proportion of smmmerwool; thus, in a disk of longleaf, for instance, there is on the nortlı sicle a radins of $152 \mathrm{~mm}$. with 27 per cent summerwood; on the sonth side a rallins of 98 min. and a summerwood per cent of only 20 per cent. In the stmmp section the great irregularity in the eontour of the rings is aceompanied by a corresponding irregnlarity in the ontline of the summerwood.

The snmmerwood generally forms less than half of the total rohme of the whole log (see fig. 13); it forms a greater part of the eoarse grained wood which was grown while the tree was yomig than in the fune-ringed onter parts of the log, grown in the old age perind. It also forms a greater part in the volume of the butt than of the top log, and thus fully explains the well-kinown difference in the weight, strength, and valne of the varions parts of the tree. The following table serves to illustrate this point. The numbers in each line refer to the average values for the same ten ammal layers through three seetions of the tree at varying height. The finness in ilaliess below refer to specifie gravity for the same layer. The values for specifie gravity were ealenlated on the basis of 
allowing a speeific gravity of 0.40 for springwood and 0.90 for summerwood, the values for the entire disks as aetually observed being given below:

Summeruod per cent and specific gravity in various parts of a tree of Longleaf Pine.

\begin{tabular}{|c|c|c|c|c|c|c|c|c|c|c|c|c|c|c|c|c|c|c|c|c|c|c|c|c|c|}
\hline Rings from periphery. & $\begin{array}{l}1 \\
\text { to } \\
10\end{array}$ & $\begin{array}{l}11 \\
\text { to } \\
20\end{array}$ & $\left|\begin{array}{l}21 \\
\text { to } \\
30\end{array}\right|$ & $\begin{array}{l}31 \\
\text { to } \\
40\end{array}$ & $\begin{array}{l}41 \\
\text { to } \\
50\end{array}$ & $\begin{array}{l}51 \\
\text { to } \\
60\end{array}$ & \begin{tabular}{|l|}
61 \\
to \\
70
\end{tabular} & $\begin{array}{l}71 \\
\text { to } \\
80\end{array}$ & $\begin{array}{l}81 \\
\text { to } \\
90\end{array}$ & \begin{tabular}{|c|c|}
91 \\
to \\
100
\end{tabular} & $\begin{array}{c}101 \\
\text { to } \\
110\end{array}$ & $\begin{array}{l}111 \\
\text { to } \\
120\end{array}$ & $\mid \begin{array}{c}121 \\
\text { to } \\
130\end{array}$ & $\begin{array}{c}131 \\
\text { to } \\
140\end{array}$ & $\begin{array}{c}141 \\
10 \\
150\end{array}$ & $\begin{array}{c}151 \\
\text { to } \\
160\end{array}$ & $\begin{array}{c}161 \\
\text { to } \\
170\end{array}$ & $\begin{array}{c}171 \\
\text { to } \\
180\end{array}$ & $\begin{array}{c}181 \\
\text { to } \\
190\end{array}$ & $\begin{array}{c}191 \\
\text { to } \\
200\end{array}$ & $\mid \begin{array}{c}201 \\
\text { to } \\
210\end{array}$ & $\begin{array}{c}211 \\
\text { to } \\
220\end{array}$ & $\begin{array}{c}221 \\
\text { to } \\
2: 30\end{array}$ & $\begin{array}{c}231 \\
\text { to } \\
238\end{array}$ & $\mid \begin{array}{l}\text { Aver- } \\
\text { age } \\
\text { for } \\
\text { total. }\end{array}$ \\
\hline Section I, 3 feet from ground. & $\begin{array}{r}39 \\
.59\end{array}$ & .62 & $\begin{array}{r}40 \\
.60\end{array}$ & $\begin{array}{l}42 \\
.61\end{array}$ & $\begin{array}{l}38 \\
.59\end{array}$ & $\begin{array}{r}35 \\
.57\end{array}$ & $\begin{array}{r}45 \\
62\end{array}$ & $\left|\begin{array}{r}32 \\
.56\end{array}\right|$ & $\begin{array}{l}44 \\
.68\end{array}$ & $\begin{array}{r}66 \\
.73\end{array}$ & $\begin{array}{r}43 \\
.61\end{array}$ & $\begin{array}{r}43 \\
.61\end{array}$ & \begin{tabular}{|l|}
52 \\
.66
\end{tabular} & $\begin{array}{r}56 \\
.68\end{array}$ & $\begin{array}{r}48 \\
.64\end{array}$ & $\begin{array}{r}46 \\
.63\end{array}$ & $\begin{array}{r}48 \\
.64\end{array}$ & $\begin{array}{r}43 \\
.61\end{array}$ & $\begin{array}{r}47 \\
.63\end{array}$ & $\begin{array}{r}47 \\
.68\end{array}$ & $\begin{array}{r}52 \\
.66\end{array}$ & $\begin{array}{r}45 \\
.62\end{array}$ & $\begin{array}{r}42 \\
.61\end{array}$ & $\begin{array}{r}a 15 \\
.47\end{array}$ & $\begin{array}{r}45 \\
.625\end{array}$ \\
\hline 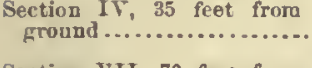 & $\begin{array}{l}26 \\
.58\end{array}$ & $\begin{array}{l}24 \\
.52\end{array}$ & $\begin{array}{r}25 \\
.52 \\
\end{array}$ & $\begin{array}{l}34 \\
.57 \\
\end{array}$ & $\begin{array}{r}28 \\
.54\end{array}$ & $\begin{array}{r}24 \\
.52 \\
\end{array}$ & $\begin{array}{r}26 \\
.59\end{array}$ & $\begin{array}{r}24 \\
.59\end{array}$ & $\begin{array}{r}35 \\
.67\end{array}$ & .69 & $\begin{array}{c}31 \\
.55\end{array}$ & \begin{tabular}{|l}
33 \\
.56
\end{tabular} & $\begin{array}{c}43 \\
.61\end{array}$ & $\begin{array}{r}34 \\
-57\end{array}$ & $\begin{array}{r}40 \\
.60\end{array}$ & $\begin{array}{c}31 \\
.55\end{array}$ & $\begin{array}{r}34 \\
.57\end{array} \mid$ & $\left|\begin{array}{l}33 \\
.66\end{array}\right|$ & $\begin{array}{l}33 \\
.56\end{array}$ & $\begin{array}{r}31 \\
.55\end{array}$ & $\begin{array}{r}22 \\
61\end{array}$ & $\left|\begin{array}{l}b .6 \\
.43\end{array}\right|$ & & & .895 \\
\hline $\begin{array}{l}\text { Section YII, } 70 \text { feet fror } \\
\text { yrond ............................. }\end{array}$ & .53 & $\begin{array}{r}16 \\
.48\end{array}$ & $\begin{array}{l}17 \\
.48\end{array}$ & $\begin{array}{l}18 \\
.49\end{array}$ & $\begin{array}{r}18 \\
.49\end{array}$ & $\begin{array}{r}20 \\
.50\end{array}$ & $\begin{array}{r}16 \\
.13\end{array}$ & $\begin{array}{l}20 \\
.50\end{array}$ & $\begin{array}{l}18 \\
.49\end{array}$ & .26 & $\begin{array}{r}21 \\
.50\end{array}$ & .24 & $\begin{array}{r}19 \\
.49\end{array}$ & $\begin{array}{r}19 \\
.49\end{array}$ & $\begin{array}{r}22 \\
.51\end{array}$ & $\begin{array}{r}16 \\
.48\end{array}$ & $\begin{array}{l}18 \\
.49\end{array}$ & $\begin{array}{l}c 2 \\
.41\end{array}$ & & & & & & . & $\begin{array}{r}18 \\
.490\end{array}$ \\
\hline
\end{tabular}

a Six rings next to pith.

6 Two rings.

c One ring.

The observed values of specifle gravity for the three sections are $0.700,0.560$, a 010.490 , respectively.

It will be noticed that the grentest difference between the caleulated and the actual value of specific gravity occurs in the section at the stump. This is fully accounted for by the fact that large amounts of resin, not consilered in the values of summerwood per cent, always occur in this portion, adding from 5 to 20 per cent to the weight of the wood.

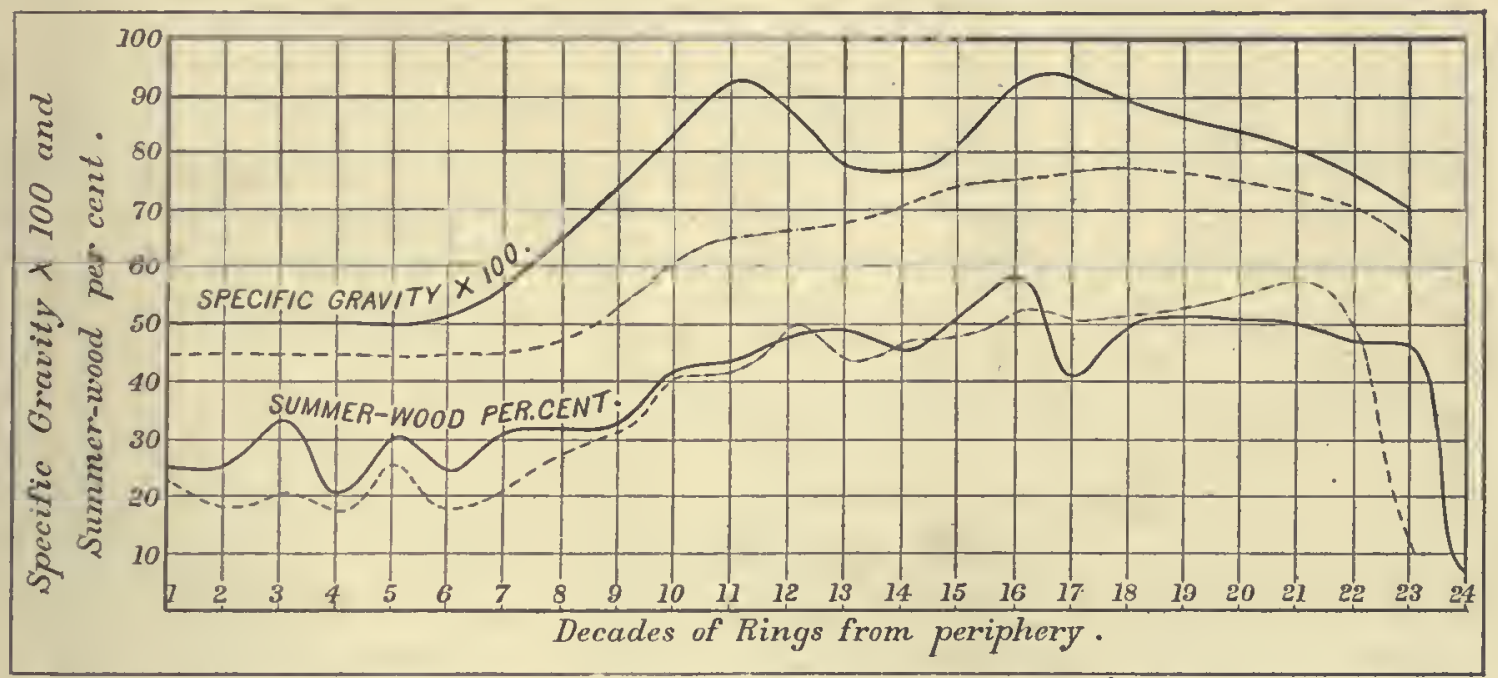

Fia. 14. - Variatlon of specific gravily with snmmerwood per cent and age of section in Longleaf Pine, the solid lines referring to a scelion 3 feet frum the gromul, the dottcd llnes to one 14 feet from the ground. (Speciflc gravity as actually observed on pieces of 1 iuch radial extent.)

In stunted trees the summerwood forms nearly as great a per cent of the total volume for the whole tree as in thrifty trees of the same age, but in the stunted growth, or extremcly narrow ringerl portion of otberwise normal trees, the per cent of summerwood is malkedly lecteaserl, a feature which beeomes conspicnons in the lighter color of the wool of such portions. (See diagram, fig. 15.) Where, on the other hand, the rate of growth in an old tree is suddenly increased by the acessibility of inore light, for instance, the summerwood per cent also is dispryportionately increased, but this disproportion appears to be more transient, i. c., a decrease in the summerwood per cent sets in sooner than for the rate of growth or the width of the rings. (Sce fig. 15.) In some of the rapidly grown Loblolly and Spruce Pine the summerwood forms but a small part of the first ten to twenty years' growth, and in all cases the first few rings abont the pith have but little summerwood. In general, the summerwood per cent varies in the sereral species as well as in the indivilual with the weight of the wood, which is least in the Spruce Pine, greatest in Cnban and Longleaf Pinc, and stands between these in Loblolly and Shortleaf. It furnishes a very useful criterion to distinguish betwecn these groups and espccially to select strong timber. 
In the limb the summerwood is nost abundant in the knot (all wood practically partaking of the character of snmmerwood, at least as far as the thickness of eell walls is concerned) aud in the part next to the stem, decreasing with the distance from the trunk. As miglit be expected, it also forms a larger per cent of the wood of the underside of limbs and the concave portions of bent trunks.

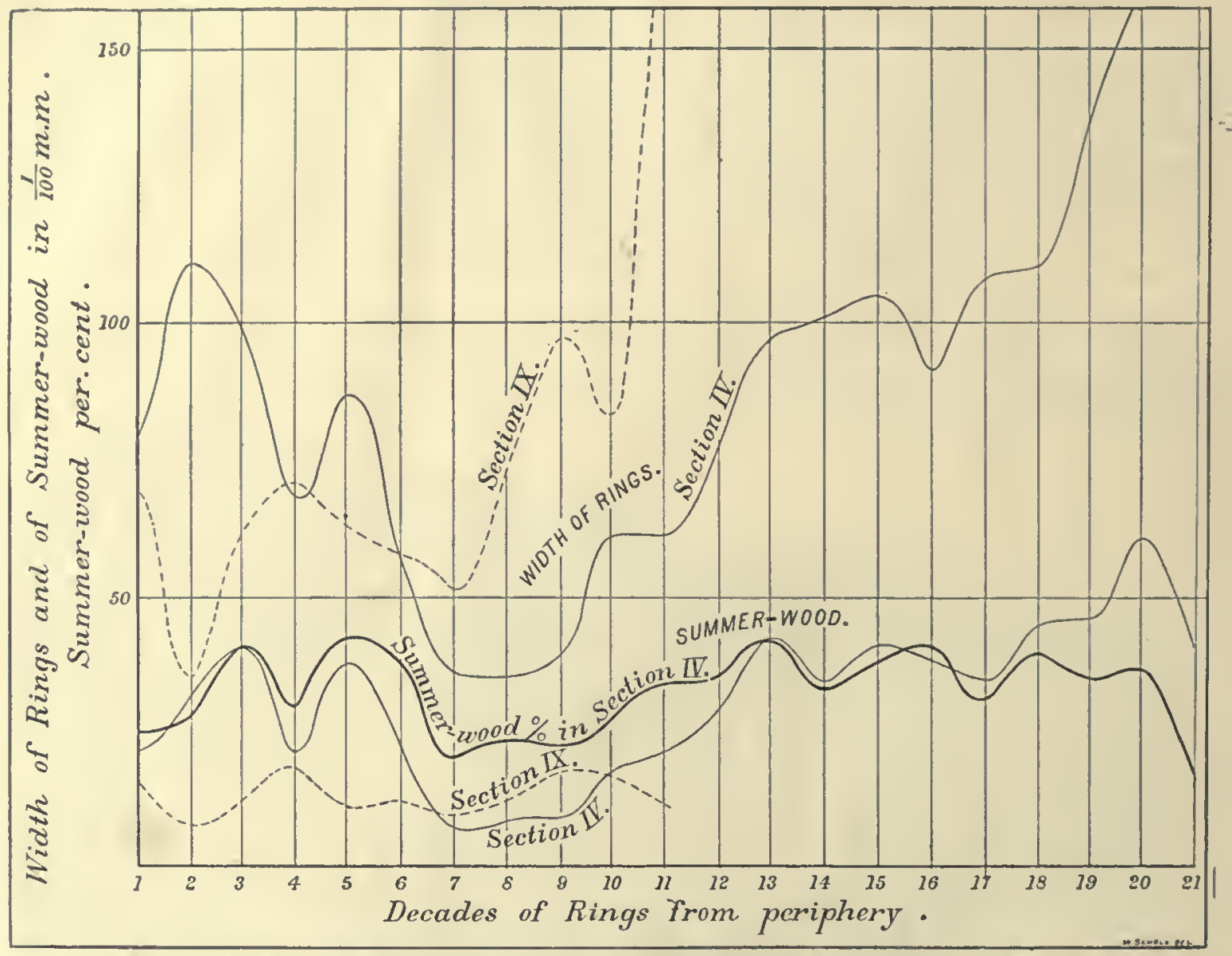

Fra. 15.-Fariation of summerwood per cent with rate of growth (width of ring), in tree No. 3, Longleaf Pino.

Nore.-Only the heary line represents summerwood per cent; the others indicate the actual width of the rings (upper pair) and of the las of summerwood (lower pair).

\section{GRAIN OF THE WOOD.}

T'hough usually quite straight grained, the wood of these species is by no means always so. Spiral growth leading to "cross-grained" lumber oceurs frequently, is nsually more pronomced in the basal portions of the tree, and eommonly varies from pith to bark in the same log. Wavy grain resembling that of the maple (eurly maple) has not been observed, but an irregular wavy grain, due to the faet that the surface of the trunk for many years is eovered with small, low cminences, 1 to a few inehes across, is frequently scen, especially in Longleaf Pine, and leads to remarkably pretty patterns. Unfortunately the contrast of spring and summer wood being so very prononnced, the figures are somewhat obtrusive and, therefore, not fully appreeiated.

\section{MINUTE ANATOYY:}

The minute strneture or histology of the wood of the five species under eonsideration is that of a group whose position in a general elassifieation of the wood of pines is indicated in the follow. ing seheme, suggested by Jr. J. Sehroeder, and more eompletely by Dr. H. Mayr, ${ }^{1}$ in which they appear as part of group 2 of Section 1.

' Dr. J. Schroeder, Holz der Coniferen, Dresden, 1872, p. 65; Dr. H. Mayr, Waldungen von Nordamerika, MHtinchen, 1890, p. 426 . 
Sectiou I. Walls of the tracheids of the pith ray with dentate projections.

a. One to two large, simple pits to each tracheid on the radial walls of the cells of the pith ray. - Group 1. Represented in this country by $P$. resinosa.

b. Thrce to six simple pits to each tracheid on the walls of the cells of the pith ray.-Group 2. $P$. tada, palustris, etc., including most of onr "hard" and "yellow" pines.

Section II. Walk of tracheids of pith ray smooth, withont dentate projections.

a. One or two large pits to each tracheid on the radial walls of each cell of the pith ray.-Group 3. P. strobus, lambertiana, and other true white pines.

$b$. Three to six small pits on the radial walls of each cell of the pith ray.-Group 4. P. parryana, ant other nut pines, including also $P$. balfouriana.

The general features of structure of coniferons woods are represented in the accompanying cut '(fig, 16).

The structural elements, as in all pine, are few and simple and consist of (a) tracheids, the common wood fibers, forming over 90 per cent of the volume; (b) medn Ilary or pith rays, minute cell aggregates composed of two kinds of cells, scarcely visible without magnifier and then only on the radial section, yet forming about 7 to 8 per cent of the volume and weight of the wood in these species; (c) resin ducts, small passages of irregular length surrounded by resin-secreting cells, scattered through the wood, but forming two more or less connected systems, one ruming in the direction of the fibers, the other at

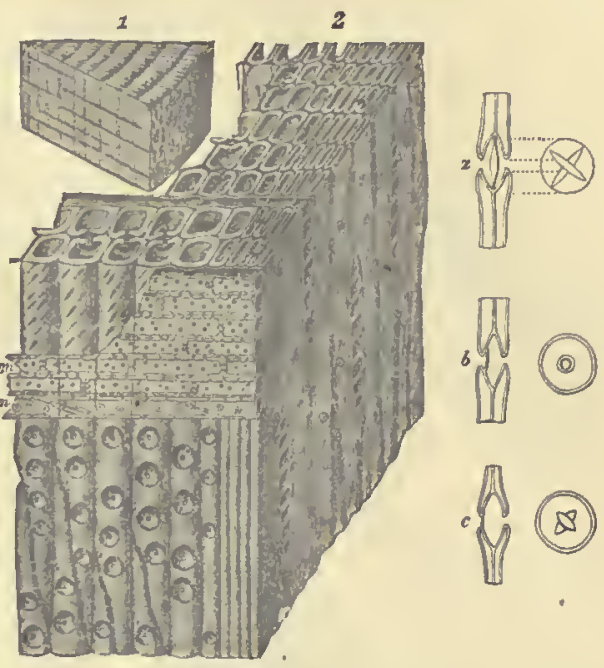

FIG. 16.-Schematic representation of coniferons wood structure: wood of spruce-1. natural size; 2, small part of one ring magnified 100 times. The vertical tubes are wood fibers, in this case all "tracheids," $m$, medullary or pith ras; $n$, transverse tracheids of pith ray; $a, b$, aud $c$, lordered pits of the tracbeids more enlarged.

right angles to the first, the individual ducts of the latter systen always ocenpying the middle portion of mednllary rays (see Pl. XXVIl).

The tracheids, or common wood fibers, are alike in all five species, and resemble those of

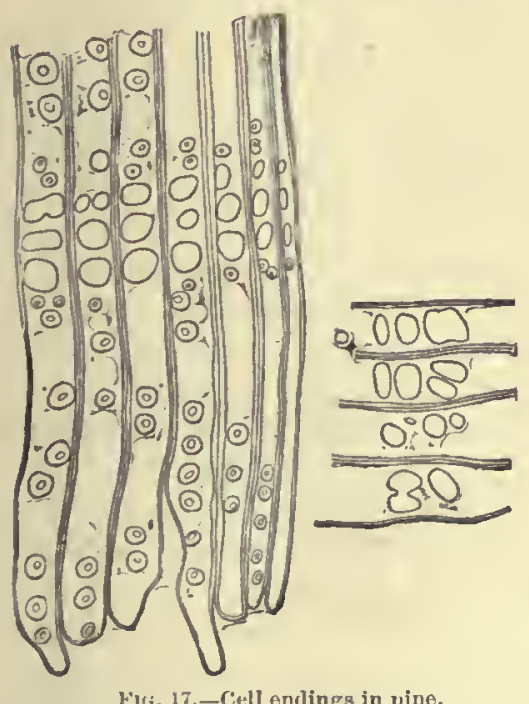

Fis: 17,-Cell endings in pine. other pines; they are slender tubes, 4.5 to $6 \mathrm{~mm}$. (about onefourth inch) long, forty to one hundred times as loug as thick, nsually liexagonal in cross section, with sharp or more or less rounded outlines (see PI. XXI), flattened in tangential direction at both ends (see PI. XXI, A $f^{\prime}$ ), the dituneter in radial direction being 45 to $55 \mu$ (about 0.002 inch) in the springirood, and about half that, or 21 to $25 \cdot \mu$, in the sunmerwood, and in tangential direction about $40 \mu$ on the average in their middle. They are arranged in regular radial rows (see PI. XXI), which are continuons through an indefinite number of rings, but the number of rows increasing every year to accommodate the increasing circumference of the growing stem. (See Pl. XXI, C c.) The fibers of the same row are practically conterminous, i. e., they all have about the same length, though at their ends they are often bent, slightly distorted, and usually separated (see PI. XXI, B c; also fig. 17), tlieir neighbors filling ont the intersplaces. There js no constant difference in the dimensions of these fibers in the different species here considered. In every tree the fibers are shortest and smallest near the pith of any section, rapidly increasing in size from the jitl outward, and reaching their full size in about the tenth to twentieth ring from the pith. To illustrate: In a section of Longleaf Pine, 10 feet from the ground, the dianeter of tracheids in radial direction is in $\mu=0.001 \mathrm{~mm}$ : 


\begin{tabular}{|c|c|c|c|}
\hline $\begin{array}{l}\text { Nimuber of } \\
\text { rings froul } \\
\text { center. }\end{array}$ & $\begin{array}{l}\text { Spring- } \\
\text { wool. }\end{array}$ & $\begin{array}{l}\text { Summer- } \\
\text { wood. }\end{array}$ & Average. \\
\hline $\begin{array}{r}1 \\
2 \\
3 \\
1 \\
7 \\
10 \\
24-33 \\
44-53\end{array}$ & $\begin{array}{l}\mu \\
24 \\
34 \\
45 \\
43 \\
50 \\
52 \\
32 \\
52\end{array}$ & $\begin{array}{c}\mu \\
15 \\
23 \\
24 \\
26 \\
26 \\
28 \\
28 \\
27\end{array}$ & $\begin{array}{c}\mu \\
24 \\
32 \\
40 \\
36 \\
38 \\
36 \\
36 \\
37\end{array}$ \\
\hline
\end{tabular}

As usnal in eonifers, the tracheids are largest in the roots and suallest in the limbs. In these pines, espeeially in Longleaf Pine, they aro larger in well-grown wood than in that of extrenely stunted trees, though very uarrow rings in otherwise normal trees fo not share this diminutive size of the traeheil. (See fig. 18, $A$ and 13 , where a few very uarrow rings are made normal size.)
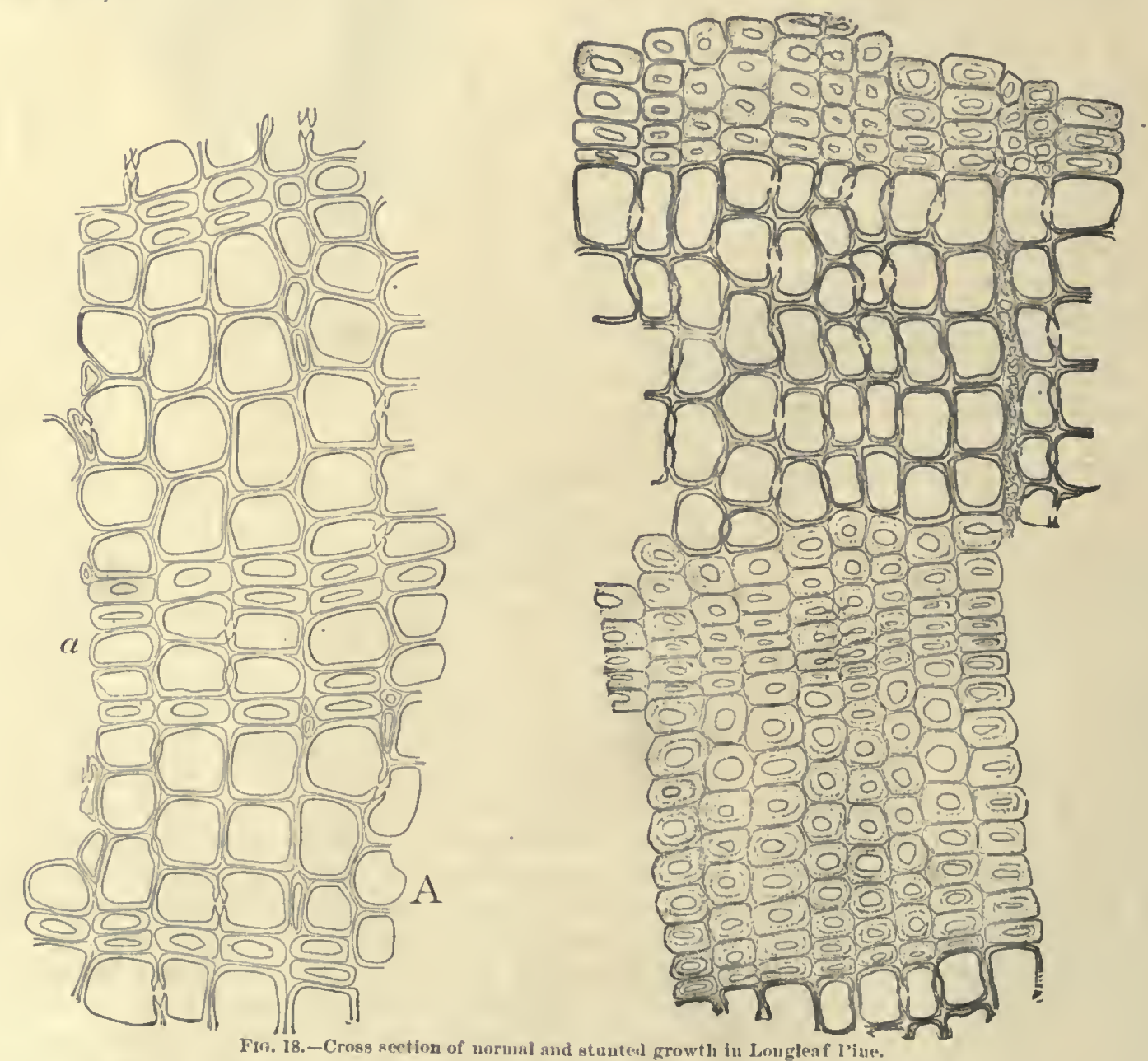

The following average figures illustrate the difference between wood from very stmited trees and that of normal trees in Iongleat Pine, of whieh we give an average from an extensive series examined :

\begin{tabular}{|c|c|c|c|c|}
\hline $\begin{array}{c}\text { Number of } \\
\text { tree. }\end{array}$ & Age. & $\begin{array}{l}\text { A verago } \\
\text { widt ho ring. }\end{array}$ & 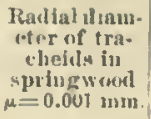 & $\begin{array}{c}\text { Character of } \\
\text { true. }\end{array}$ \\
\hline $\begin{array}{l}4 \\
5 \\
6 \\
7\end{array}$ & $\begin{array}{l}86 \\
60 \\
70 \\
08\end{array}$ & $\begin{array}{r}\text { Mrillimeters. } \\
0.40 .5 \\
.4 \\
.4 \\
2.0\end{array}$ & $\begin{array}{r}31-36 \\
30-36 \\
313-38 \\
52\end{array}$ & $\begin{array}{c}\text { St untod. } \\
\text { Do. } \\
\text { Do. } \\
\text { Sirmai. }\end{array}$ \\
\hline
\end{tabular}


As soon as the average width of the amunal rings gets above $0.5 \mathrm{~mm}$. the dimensions of the elements approach the normal. Thus, in trees Nos. 1 and 2 , with average width of annual rings 0.5 to $0.6 \mathrm{~nm}$., the average dianeter of the traehcids in radial direetion is 35 to $48 \mu$.

Normally, the diameter in rudiai direction is greatest in the first-formed or inner part of any ring, and decreases even before the summerwood is reached. In narrow lings with an abrupt begiuning of the sunmerwood, so eommon in these Southern pines, the diameter is quite eonstant throughont the springwood, but changes, together with the thickness of the wall, quite suddenly with the beginning of the summerwood, thus adding to the sharpmess of the ontlines of the two parts. (See l'l. XXI; also fig. 18, B.) In nearly all seetions there is an additional marlied decerense in radial diameter in the last 3 to 5 eells of each row, which helps to euphasize the limits of the ring. In the so-called "false" rings, mentioned before, the eells of the false summerwood part resemble those of the norntal summerwood. 'The reeognition of the false ring as such rests upon the difference in shape and dimeusions of the last eell tows in comparison with those adjoining. In the true sumnerwood the last cells are much flattened, with small lumen and somewhat reduced walls makiug a sharp definition toward the springwood of the next ring, whieh is still finrther accentuated by the wide limen and thin wall of the eells of the latter. In the "false" snumerwood, on the eontrary, the end cells are not flattened, and the cells of the light-colored adjoining zouc of wood lave but a moderately wide lumen and compratively thick walls. The fact that the outline is less regular aud commonly ineomplete-i, e., it does not extend al:und the entire seetion-also aids in reeognizing the false rings. In the "luues" of both linb and stem referred to above the fibers are smaller, more romded in cross section, and comnonly exhibit conspicuous intercellular spaees between them. The walls of these are often mueh thicker than those of the summerwood of the sane ring at this point. Since the radial diameter of the fibers of the summerwood is only about halt as great as that of the springwood, it is clenc that the number of fibers of the summerwood forms a luuch greater per cent of the total number of fibers than is indicated in the per ceut of summerwood given above and based upon its relative wilth. Thus, iu wood lraving 50 per cent of summerwood there are, in number, twiee as many tracheids in the summerwood as in the springwood.

The walls of the cells are generally abont 3 to $3 \frac{1}{2} \mu$ thick in the springwood, while in the sunmerwood they are 6 to $7 \mu$ thiek on the tangential side and 8 to $11 \mu$ thick on the radial side of the fiber. Generally it may be said that the thickness varies inversely as the extent of the wall, i. e., the greater any diameter the thinner the walls parallel to this diameter, which gives the inpression that cach cell is furnisher an equal quantun of material out of which to constrnet its louse aud had the tendeney of giving an equal amount to each of its four or six sides.

Generally the absolute width of the ring does not affect the thickness of the cell walls, the fibers of wide rings lhaving no thicker walls than those of nartow rings; but when the growth of a tree is unusually suppressed, so that the rings are less than $0.5 \mathrm{~mm} .(0.02$ inch) wide aud eaclu row consists of only a few fibers, the walls of the fiber's of the summerwood, like those of the lastforned 2 or 3 fibers of ucrmal riugs, are thinner, so that in these eases the wood is lighter in color and treight not only because there is relatively less summerwood, but also because the fibers of this summerwood have thinner walls. (See fig. 18, A and B.) In very stunted trecs, where the rings are all very narrow, the reduced thickness of the walls is counterbalaneed by the smaller size of the eells.

All tiacheids eommunicate with each other by mems of the eharacteristie "bordered" pits. the strueture of which is shown in fig. 16. These pits oecrur only ou the radial walls of the fibers, They are most abnndaut near the ends of each fiber, fewest in the niddle, form broken rows, single or occasionally double. (Pl. XXIII, C.) As in other pines the pits of the sum merwood differ in appearance from those of the spriugwood. In the latter the pit appears in the eell lumen (radial view) aş a perforatell saucer-like emincuce; in tle former as a mere eleft, elongated in the direction of the longer axis of the tiber. (See Pl. XXI, B, $d$ and $e$; Pl. XXIV, D, $l$ and E, $a_{0}$ ) In both the essential part of the pit is similar, a cireular or oval cavity resembling a doulule couvex lens, witlr a thin membrane dividing it into two equal plano-convex parts. ('This membrane is shown only in the drawings, Pl. XXIV, D and $\mathrm{E}_{\text {.) }}$ In keeping with the small radial diameter of 
the fibers of the sunmerwood, these pits are mueh smaller in the summerwood than springwood, and usually are very mueh fewer in number.

The simple pits are in sets and ocenr only at the points where the fiber touehes the cells of a medullary ray. (See fig. 17, also Pl. XXIV, L, sp., and other figures of this plate and Pl. $X X V$.) Above and below these simple pits oceur very small bordered pits, communicating with those of the short transverse fibers or tracheids which form part of all inedullary rays. (See I'I. XXII, D, b. p.)

As in all pines, the medullary or pitl rays are of two kinds, the one small, 1 cell wide, and 1 to 10 -in large averages 5 to 7 -cells high; the other large, and each containing in the middle part a transverse resin duct. (Sec Pls. XXII, XXIII, XXV, and XXVII.) Of the former there occur about 21 to 27 on each square nillimeter (about 15,000 per square inch) of tangential section. The second class are much less abundant and scattered very irregularly, so that sometines nreas of several square uillimeters are found without any of these rays. Generally about one of these rays occurs to every 1.5 or 2 square millineters, o1" about 300 to 400 per square inch of tangential section. In all rays the cell rows forning the npper and lower edge (sec Pl. XXIII) are composed of short fibers or tracheids (transverse tracheids), while the inuer rows contain only parenchyma cells. Occasionally small rays oceur which are composed of tracliciels only. (See Pl. XXII, O.) Frequently the rows of parcnehyma are separated by one, rarely by two, series of traeheids (see Pl. XXIV, D, and Pl. XXV, D), giving rise to "double" or "triple" rays.

The number of ccll rows in each medullary or pith ray varies fron 2 to 10 , on an average from 5 to 7 , and of these the rows of tracheids or fibers form more than half. (See Pl. XXVI, where the outer cells or tracheids are marked with dots.)

The tracheids of the rays have thick walls covered with point-and bar-like projections, the boldest of which are ou the upper and lower walls and surround the bordered pits. (See Pls. XXII and XXIII.) These short tracheids communieate with the common wood fibcrs, with eaelı other, as well as with the parcuchyma cells, by means of small bordered pits, which in this last case are bordered on one side (side of the tracheid) and simple on the other (half-bordered pits). The parcnchyna cells occupying the inner rows of each ray communicate in the springwood part of the ring with each neighboring tracheid by 3 to 6 , commonly 4 to 5 , sinple elliptical pits, in tlee summerwood by a single narrow, elongated slit-like pit (see Pls. XXII and XXIII), and with eaelı other by sinall, irregular, scattered simple pits.

The walls of these eclls are gencrally smooth, but local thickenings, especially on the npper and lower walls and surrounding the pits, oceur quite frequently, though not regularly.

The pareuchyma cells of the rays are usually somewhat linader and higher than the fibers, the average height for both being about 21 to $27 \mu$, the average willth abont $20 \mu$, while the length of each cell and fiber, greater in springwood and least in the summerwond, is from two to teu times as great as the height. Assuming $25 \mu$ and $20 \mu$ to represent the average height and willth, and allowing 25 rays of 6 cell rows each to each square millineter of tangential section, then the rays form about 7.5 per cent of the total volume aud weight of the wood of these species. An attempt to utilize for purposes of identification the difference in the number, size, and distribution of these rays, or the proportion between the number of lows of tracheids and those of parenehyma eells, as was done by Dr. J. Schroeder, ${ }^{1}$ has not bcen successful, and appears of little promise.

The large rays with trausverse resin ducts resemble the smaller rays described. On Pl. XXY at $\boldsymbol{A}$ such a ray is seen both in radial and tangential section. Series of transverse tracheids oecupy the upper and lower elge, but the interior, unlike that of common rays, is several cells wide, and contains an open duet in its widest portion. (Sec Pl. XXVII, $r$. l.) This duet is comnonly more or less filled with resin (sce Pl. XXVII, E); it is surrounded by thin-walled sccreting cells, and, in the heart wood, often divided or filled up by thylosis, i. e., by very thin walled, much puffed out cells, growing out of the surrounding secreting cells before the latter perish.

The walls of the secreting cells are quite thin, those of the remainder of the parenelyma vary to some extent in the different spccies. In the Longleaf and Loblolly Pines the walls of the parenchyma composing the principal part of tle ray are generally quite thick (see Pl. XXVI, A-E), 
thicker than those of the cells of ordinary rays, aud espeeially thickened near the simple pits by which these cells communieate with each other. In Cubau and Shortleaf this thiekening is much less conspicuous, and absent eutirely in many eases (see Pl. XXV, A), while in the Spruce Pine it seems wanting altogether.

These ducts exist even in the very first ring (next to the pith), are smaller and more numerons ncar center, buiv have essentially the same structure in the wood of the fifth and later years.

The tracheids of the pith rays are wanting next to the pith, but oceur in all rays iu the outer part of even the first ring. The rays in this riug are generally lower, eomposed of fewer eell rows, but the cells are larger than in the rest of the wood.

Both shape and size of these medullary rays are very variable; an average of about $0.4 \mathrm{~mm}$. for the height of the ray and $60 \mu$ for the width at the resin duct was observed. Au attempt to utilize the shape, especially the appearanee of the two edges, as a meaus of separating the wood of these species has so far fiviled entirely.

The large resin duets running lengthwise iu the wood or parallel to the conmon wood fibers are much larger than the transverse duets, measuring, inelusive of the secretive eells, on an average about $0.2 \mathrm{~mm}$. (0.008 inch) ou their smaller radial dianeter and about $0.3 \mathrm{~mm}$. on the tangeutial. (See Pl. XXI, A, r. d.) They are usually situated in the summerwood of each ring, often in narrow rings, eausing an irregular outline. They are smaller and more numerous near the pith, here nsually forming several series in one annual ring, more numerous in wide rings than in narrow oues, but their number per square inch of eross seetion as well as their dimensions appear to be independeut of the width of the rings. In their structure they resemble those of other pines. They are surrounded by thin-walled resin-secreting parenchyma, part of whieh often appears as if not directly connected with the duct. (See Pl. XXI, A.) In unany cases all the tissue between two neighboring ducts is of this parenchyma. Longitudinal and transverse duets frequently meet and thus form a eontinuous network of duets throughout the wood. 


\section{PLATE XXI.-CROSS SECTIONS.}

$A$, PINUs T.EDA, 23. $r$. $d$, resin dnct; 8. c., secreting cells; $m$. r., medullary rays; $a$, section of transverse tratcleid of ray; $b$, the ray leaves the plain of the section at this point, small parts of it renplearing further on; $c$, siulle pits connecting parenchyma cells of the ray; $d-\varepsilon$, part of a row of tracheids formed during one season: $f$, Hattened terminal part of a tracheid.

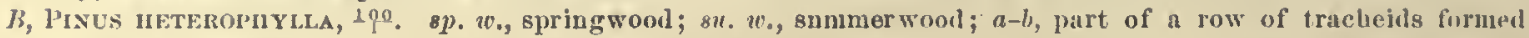
during ono season; $c$, terminal parts of tracheids; $d$, bordered pit in springwool; $c$, same in summerwoori; otlier letters as in $A$.

$C$, Pixus glabra, $1 \$ 9$. c, row of tracheids donbled; othor letters as in $B$.

Originals, all 3 go.

154 

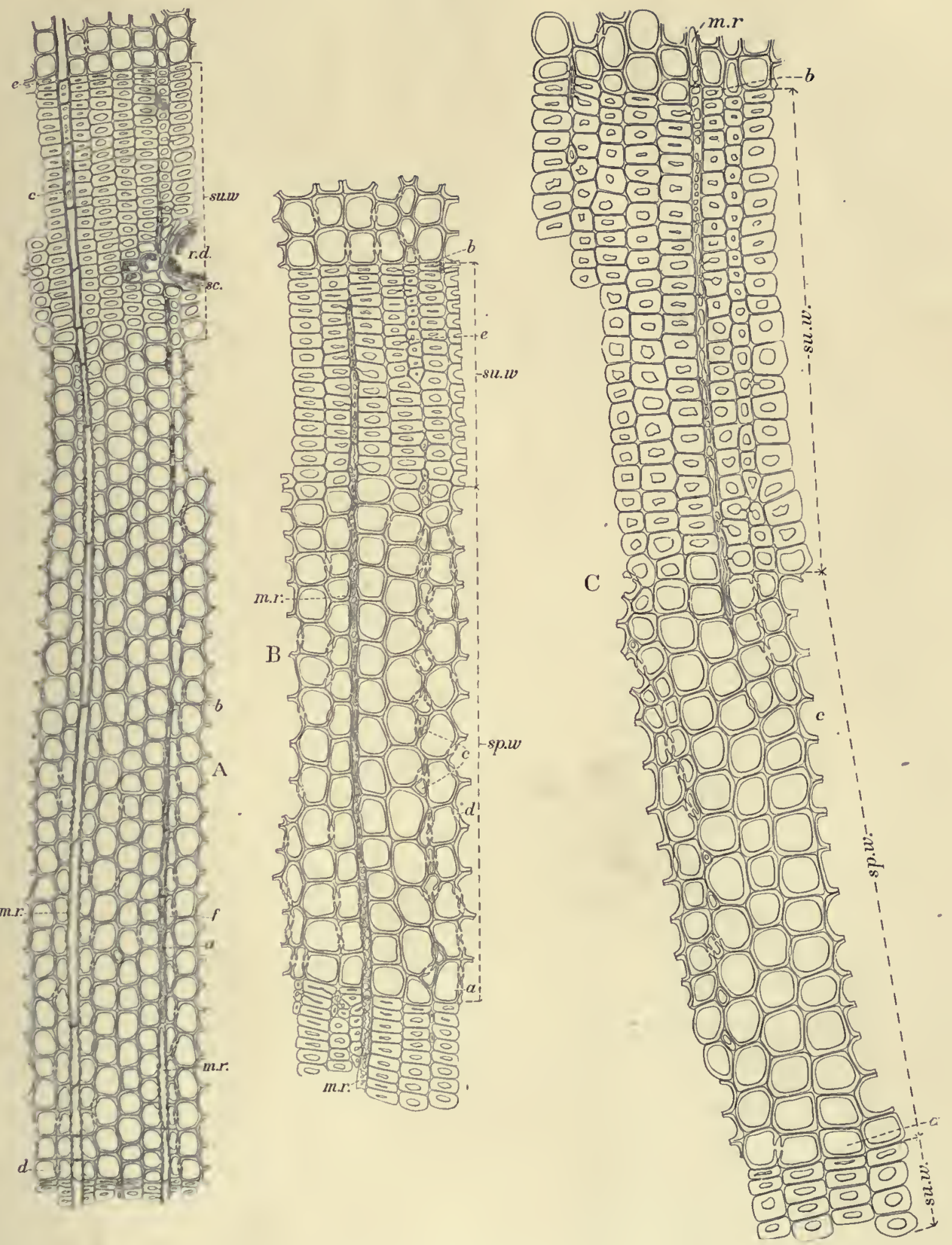


PLATE XXII.

A, l'wus rchixata. Cross section of two rung; $8 p . w$, springwood; $8 u, v$, summerwood. .

B, l'1NUS palustris. Cross section of a very narrow ring. Of the two medullary rays one is cut through a row of parenchyina, the other through a row of tracheids.

$C$ and $D$, Pivus gLABRA. Radial sections; $m . r$, medullary rags; $t r$, tracheids of the medullary rays; $p .$, parenchyma of the same; 8. p., simple pits leading from the parcnchyma to the neighboring tracheids or common filers c. $t r . ; b . p .$, bordered pit. The ray at $C$ is made up of tracheids only.

E, Punus palustris. Radial section; lettering as in $D$.

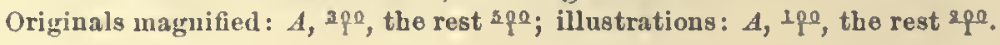




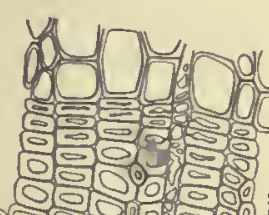
OTNm000 $300000^{-1}$ NO? Non

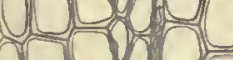
DUf
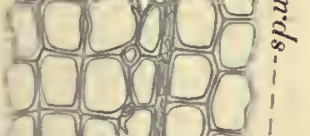
40.40 on Qी० 앙 0 oromoto 0 of 0 임ㅇ. 00 (0) 001000010 0) o 0 aro न्रणमनहिए

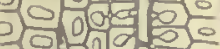

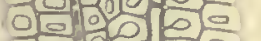

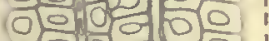
- 0 잉응

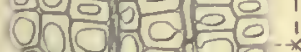
nof 00 : nO 10 non 100
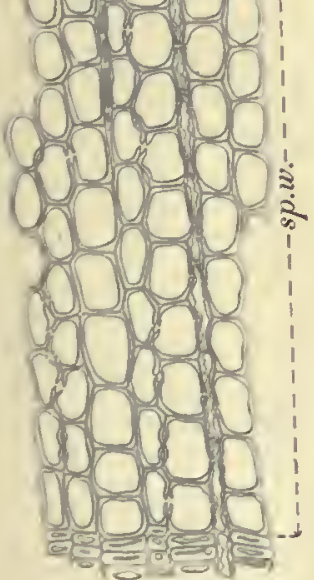
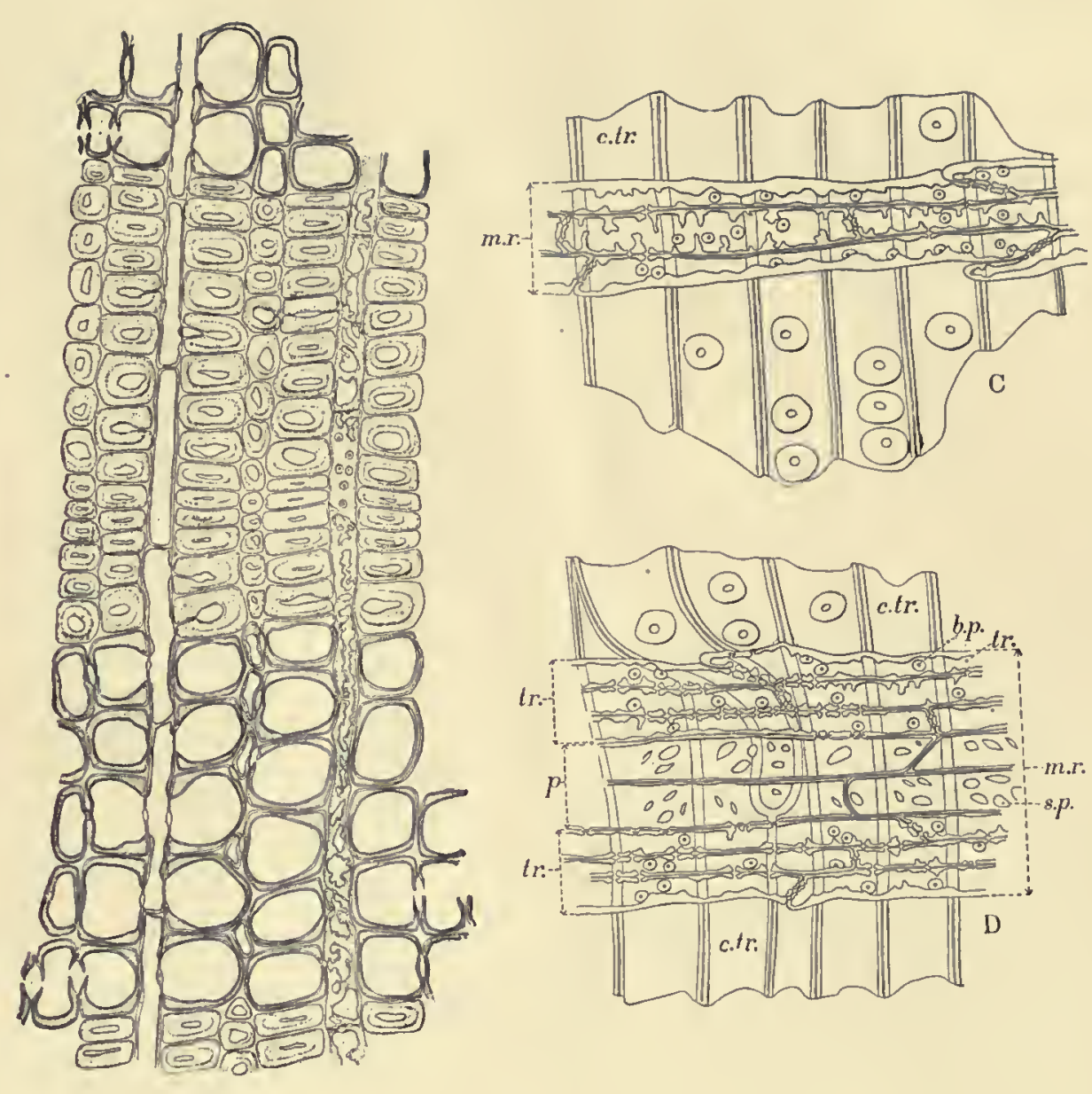

(1) $6-2$

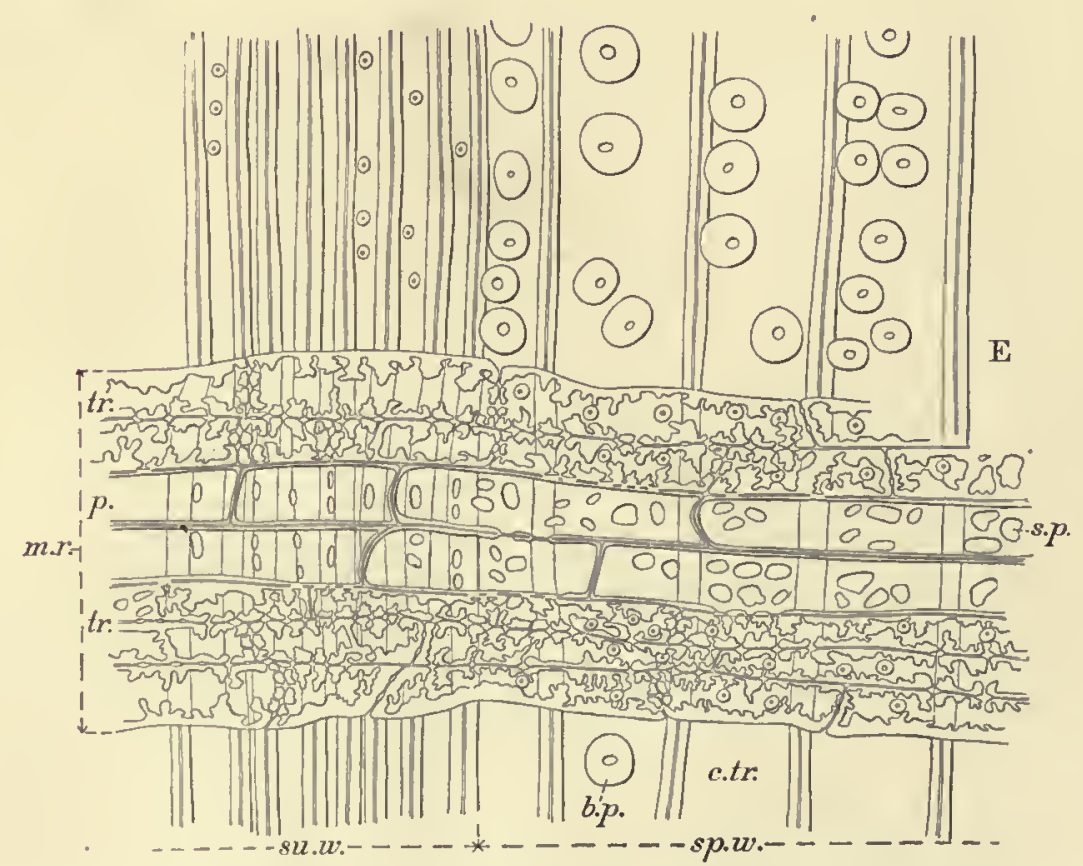

Typical Cross Sections of Pinus palustris and echinata, and Radial Sections of Pinus palustris and glabra. 




\section{PLATF, XXIII.-RADIAL SECTIONS.}

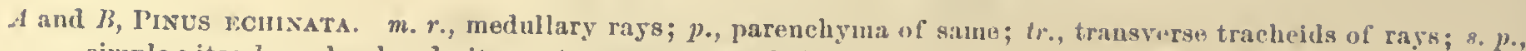
simplo pits; b. p., bordered pits; $c$. $t$, common tracheids.

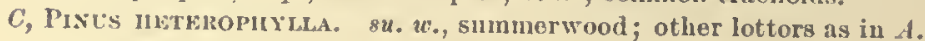

Originals magnified spo; illnstrations, $2 p^{\circ}$. 

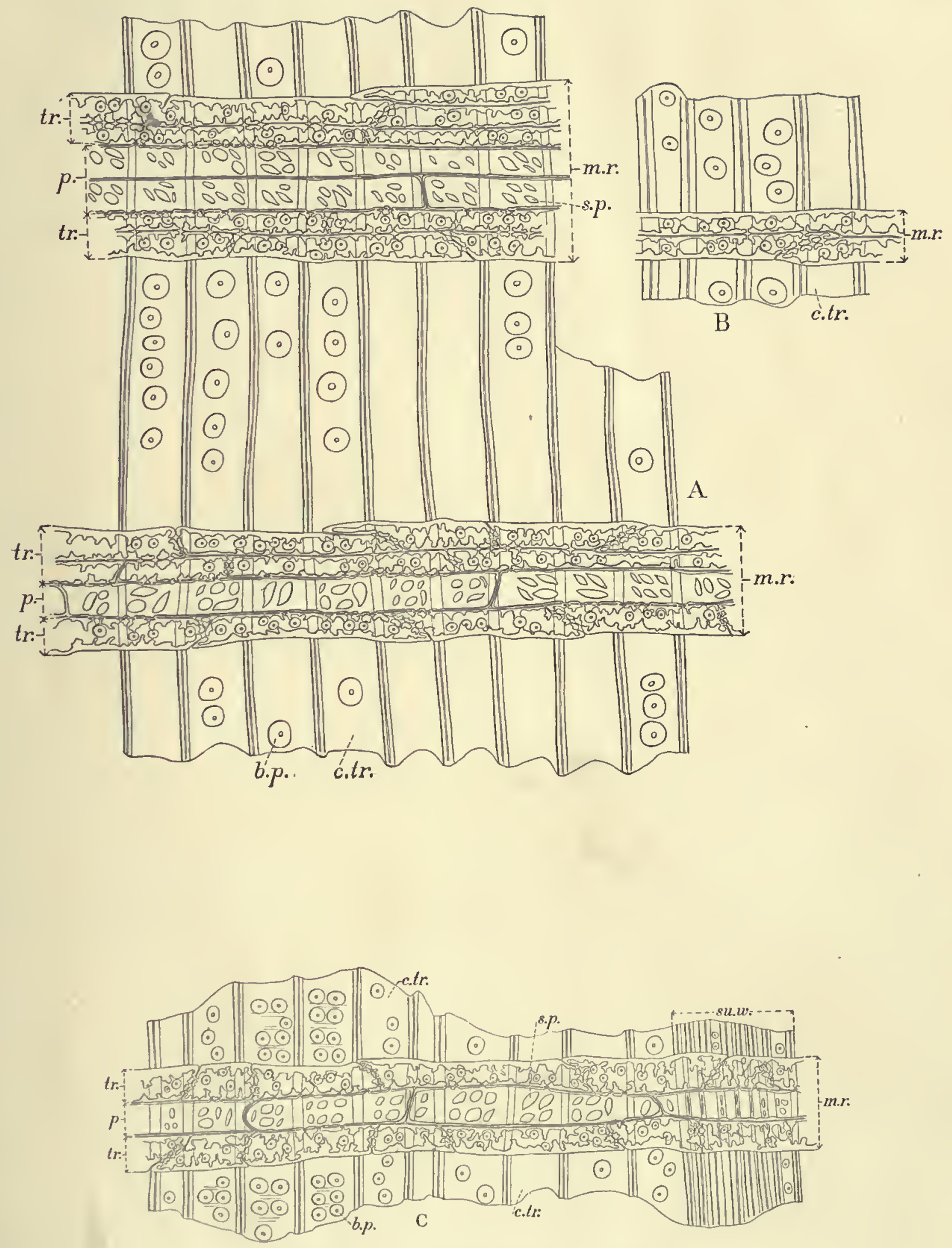

Radial Sections of Pinus ecminata and heterophylla. 




\section{PLATE XXIV.-RADIAL AND TANGENTIAL SEC'TIONS.}

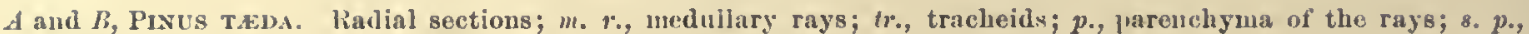
simple pit: $b$. p., borlered pit; c. tr., common tracheids.

$C-k$, tangential sections.

$C$, PINUs palustms. Left-hand part in springwood, right-hand portion in summerwool.

D-E, Pixts Echivata. D, Scction in springwood; a-c, mednllary rays; a, a suall ray composed of tracheids ouly; $c$, a "triple" ray; $d$, bordered pit showing the menbrane in plaee. $E$, Section in summerwood; $a$. bord.red pit, other letters as in $A$ and $f$.

Magnification of originals, ${ }^{5} q^{0}$; of illustrations: $f$ and $B,{ }^{2} q^{\circ} ; C-E,{ }^{3} q^{0}$. 

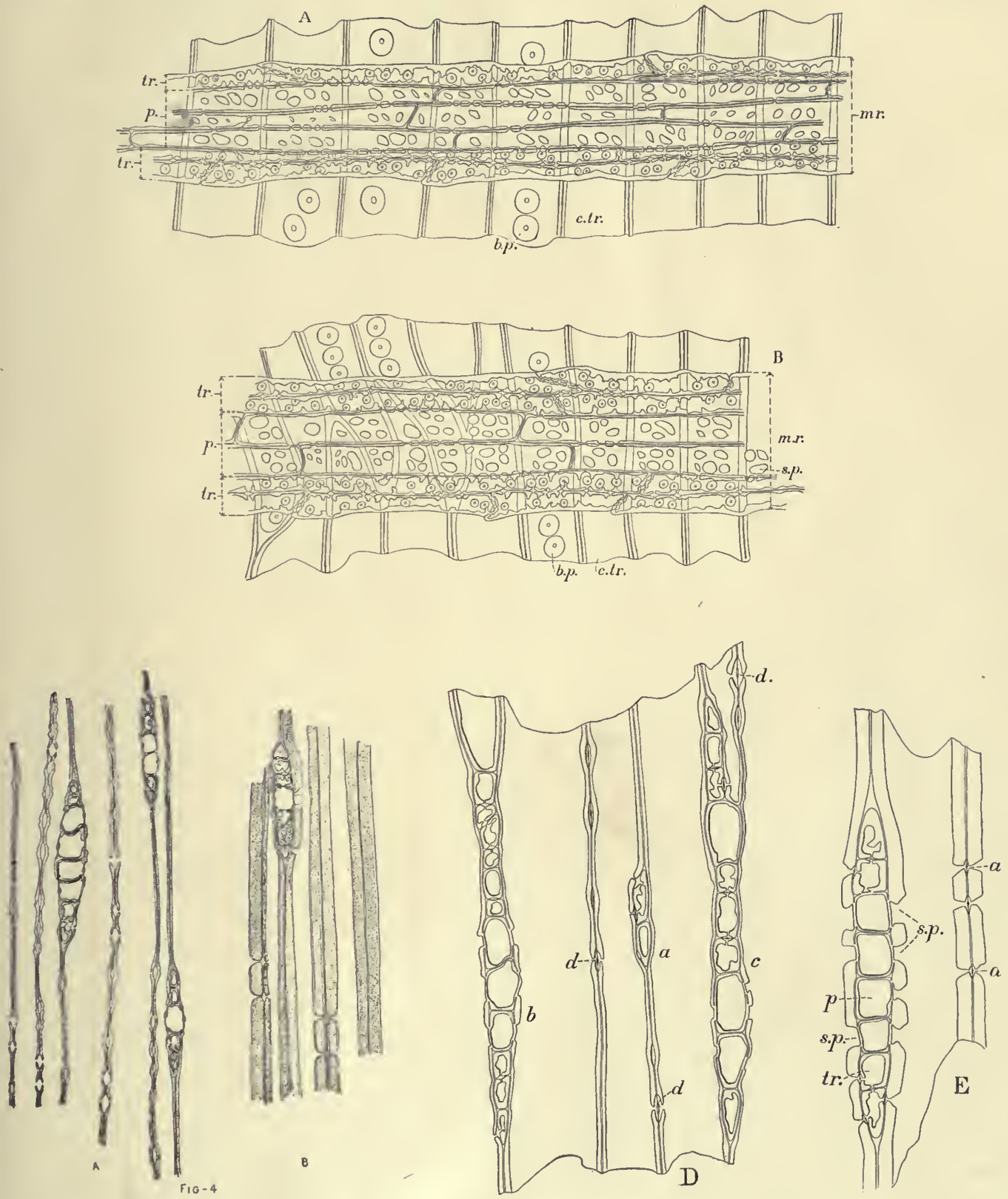

Radial Sections of Pinus teda and tangential Sections of Pinus palustris and echinata. 

$7092-$ No. $13-11$. 


\section{PLATE XXV.}

A, l'inUs Heteropiycha. Radial and tangontial sections of a transverse resin dnct; $r$. d., resin duct; $m$. $r$, mednllary ray; $t$., tracheids of tho melullary ray; $p$. parenchyna cells of the sane; r. tr., common tracheids or wood fibers.

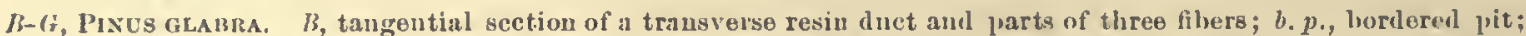
other letters as above; $C-G$, tangoutial sections of ublullary rays, of which $E$ is made up of tracheids only, while $D$ is a "triple" ray.

U, PINes TFDA. Tangential sections of unedullary rays in spring aud sumer wool. Originul magnitied 500 times, illustrations abont $3 p^{0}$. 
Bulietin No. 13, Division of Forestry.
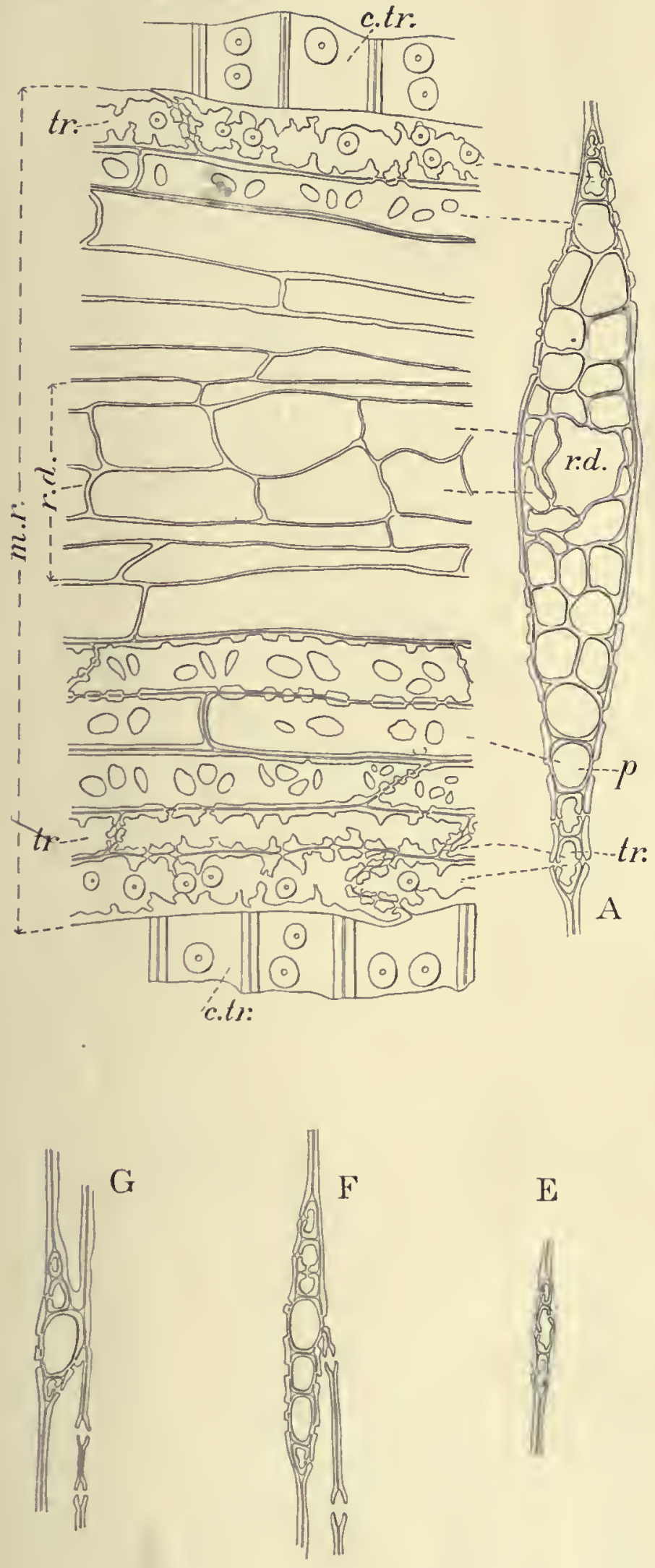

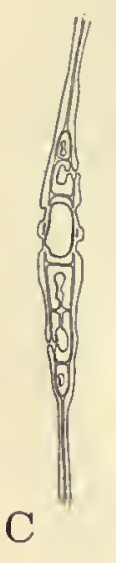

$\mathrm{D}$

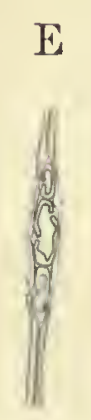

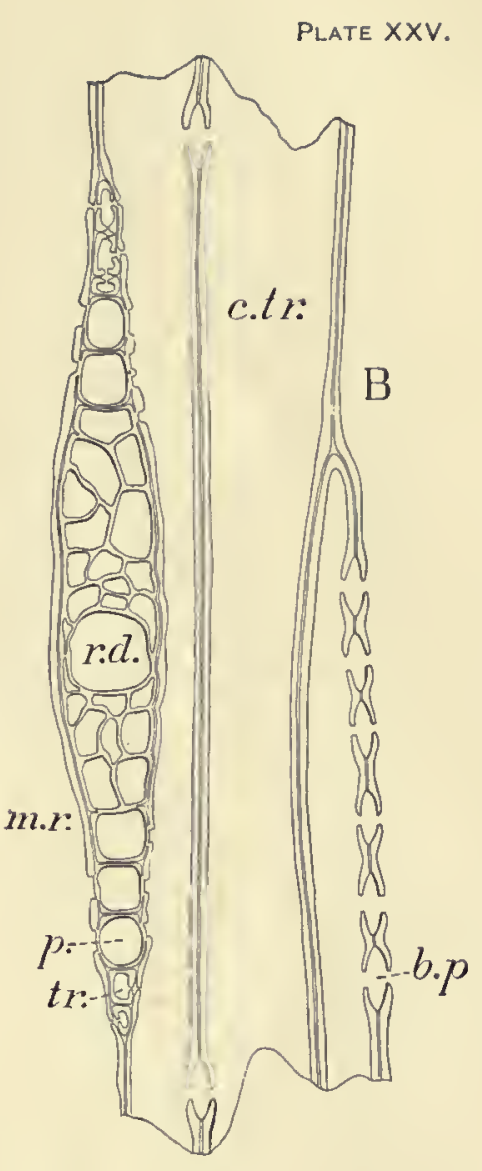

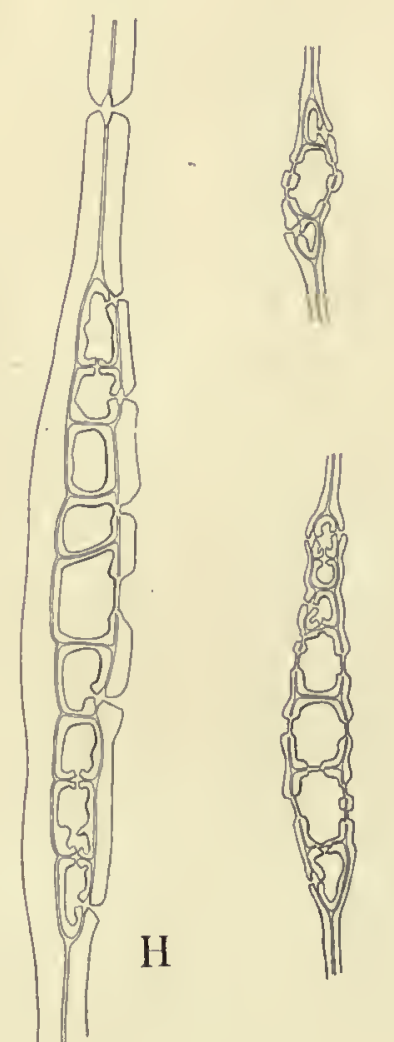

TANgential sections of Pinus teda, heterophylla, and glabra. 


PLATl: XXVI.-TANGENTIAL SICTIONS.

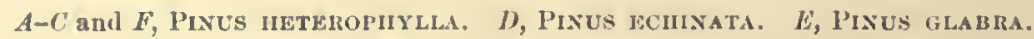

$A-C$, sections of medullary rays; $t$., tracheids ; $p$., parenchyma; $C$ is a "donble" ray.

In $D-F$, histological details are omitted; they are cancra driwings showing number and distribution of medullary rays, and also the proportion of the tracheids to parenchyma in each ray, the former being indicated liy dots; $r$. $d$, trausverso resin ducts; $m . r$, medullary rays,

Magnification of originals: $A-C,{ }^{200} ; D-F,{ }^{5} ;$ of illnstratious: $A-C, 3 q^{0} ; D-F, \mathbf{s}^{5}$.

164 



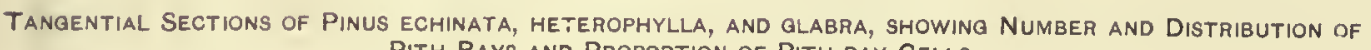
Pith Rays and Proportion of PIth-ray Cells. 





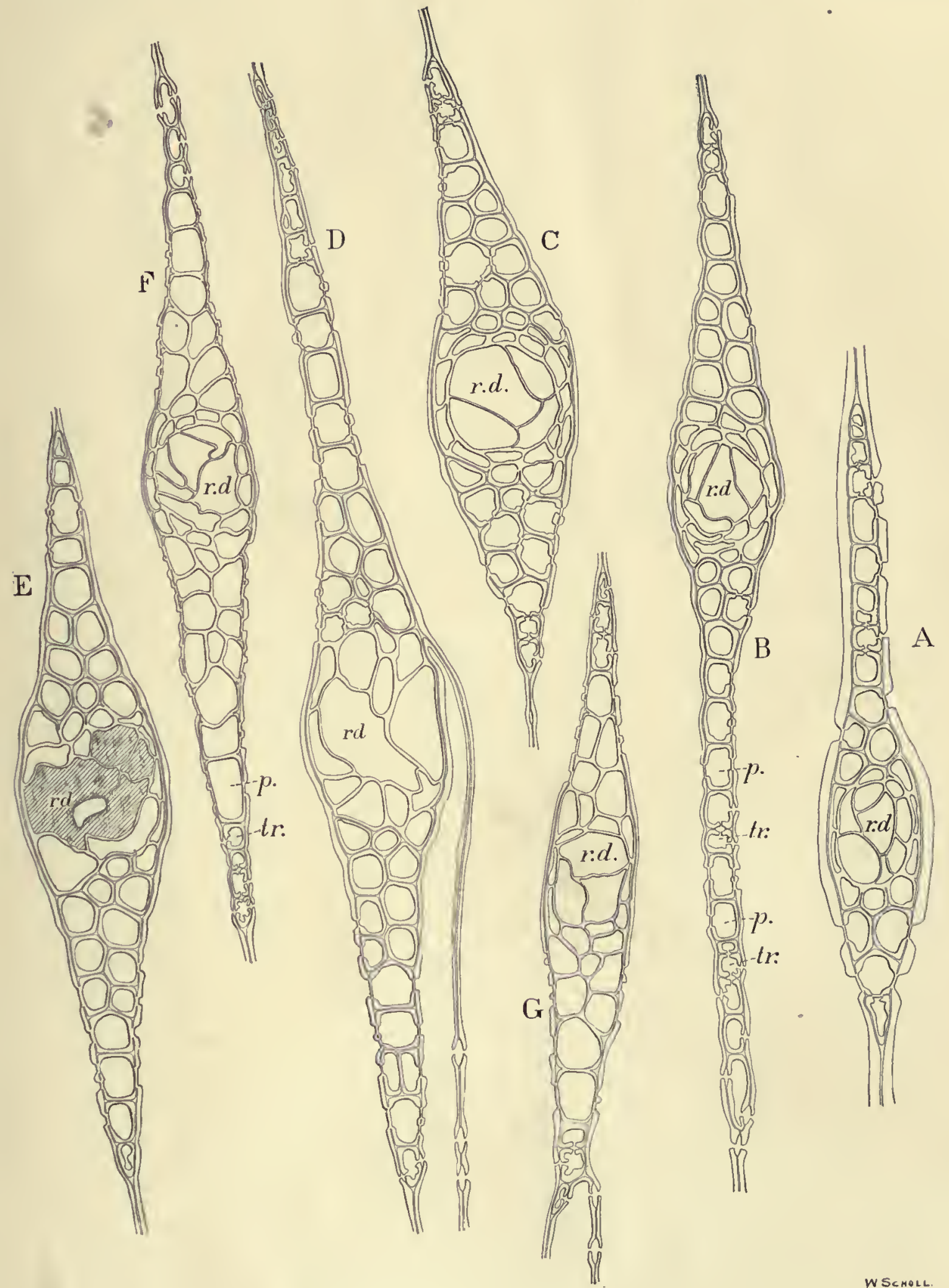



- OBSERVATIONS ON THE MARSH OR POND PINE.

(P'inus serotina.)

Distribution.

Botanical Description.

Progress of DeVelopyent.

E.CONOMIC IMPORTANCE. 



\title{
OBSERVATIONS ON THE MARSH OR POND PINE.
}

\author{
(Pinus serotina.)'
}

By Filibert Roth.

\section{DISTRIBUTION.}

The Marsh Pine of the North Carolina woodmau, or Pond Pine of botanists, is a common tree of the pinery along the Atlantie Coast from the Albcharlc Sonnd in North Oarolina to the head of St. Johns River in Florida, and oceurs also on the west side of the peninsula of Florida and along the Gulf nearly as far west as Pensacola. In passing on a train throngl the Atlantic Coast pinery this tree is rarely more than ten minutes out of sight, and generally forms small groves, or necurs mixed with other pines, sometimes over areas of many miles.

In North Carolina, espeeially in the country about the Albemarle and Pamlieo sounds, this tree is associated with and grows to the same dimensions as the Loblolly (Pinus tada), liere known as Shortleaf Pine; is cut and sold indiseriminately with this latter; and furnishes about 10 to 15 per cent of the lumber known in the market as North Carolina pine, most of which is cut in this region. From Newbern south to the State line this tree oceupies the low "sags," often alone or" with Loblolly, and forms a conspicnons admixtnre of the open, serubby, and much-culled Longleaf Pine woods whieh cover the vast flats along the railway. In the pinery along the coast of Soutl Carolina, Gcorgia, and the east half of the peninsula of Florida the Pond I'ine occupies all low flits, in South Carolina largely with Loblolly, and in Georgia and Florida mostly with Cnban I'ine. It also forms part of the forests along the shore, also eovering many of the islands.

Along the west eoast of Florida it is not so common, and like Cnban Pine is wanting in many places ipparently well suited to its growth. From Oeala and Dunnellon mp to Live Oak the tree is rarely seen, is more common in the flats east of Tallahassee, and still more so between this place and Carabelle, wliere it accompanics Cuban Pine. West of the Apalaehicola few trees werc seen, and nearing Pensaeola the speeies disappeared entirely.

In North Carolina the tree is well known to woodmen, and is distinguished as "Marsh Pine," occusionally as "Meadow Pinc;" but in the towns and to the manufaetnrers it seems generally miknown, and its logs arc never recognized. In South Carolina and Georgia the tree, as far as observed, is not well known, and whell distingnished at all bears the namc of "Spruee I'ine," a term which, like "Bnll Pinc," "Bastard Pine," ete., is eommonly rcsorted to to hide ignoranee in the premises. In Florida, south of Jacksonville, where the little Sand Pine (Pinus clausa) generally, consistently, and appropriately receives the name of Spruee Pinc, the Pond Pine is not distinguished from Loblolly, both passing under this latter nanc. Where it grows with Loblolly, as in the forests of North Carolina and along the coast, the Pond Pinc looks very inuch like Loblolly. The old trees attain the same height and thickness, the crown, bark, and even the foliagc are muelı alike, and the only striking differenee is in the eones. Young trees of Pond Pine are not distinguished from Loblolly even by observing woodmen, and as long as no concs are borne the distinction is not easy. lint besides the nnmerous very persistent cones, of wbich niny stay firmly closcd for several seasons, the peenliarity of brancling out from the stem greatly assists in reeognizing this trce in the woods. These sprout-like shoots or branches often eover the trunk for almost its entire length in a manner often scen in Pitch Pine (Pinus rigida) and also in the truo Shortleaf Pine (Pimus echnatu). In old, stnuted timber, the crown, largely in consequence of this branching,

'These observations were made during an extensive trip through the South in the spring of 1897. 



\title{
OBSERVATIONS ON THE MARSH OR POND PINE.
}

\author{
(Pinus serotina.)'
}

By Filibert Rotil.

\section{DISTRIBUTION.}

The Marsh Pine of the North Carolina wooluan, or Pond Pine of botanists, is a eommon tree of the pinery along the Atlantic Coast from the Albenarle Sonnd in Nortl Carolina to the head of St. Johns River in Florida, and ocenrs also on the west side of the peninsula of Florida and along the Gnlf nearly as far west as Pensaeola. In passing on a train throngh the Atlantic Coast pinery this tree is rarely more than teu minutes out of sight, and generally forms small groves, or neenr's mixed with other pines, sometimes over areas of many miles.

In Nortlı Carolina, espeeially in the country about the Albemarle and Pamlieo sounds, this tree is associated with and grows to the same dimensions as the Loblolly (Pinus teda), here known as Shortleaf Pine; is cut and sold indiseriminately with this latter, and furnishes about 10 to 15 pel eent of the lumber known in the market as North Carolina pine, most of which is cut in this region. From Newbern sonth to the State line this tree oeeupies the low "sags," often alone ol with Loblolly, and forms a eonspienons admixture of the open, scrubby, and nnch-cnlled Longleaf Pine woods which cover the vast flats along the railway. In the pinery along the eoast of Soutl Carolina, (ieorgia, and the east half of the peninsnla of Florida the Pond I'ine oceupies all low flats, in South Carolina largely with Loblolly, and in Georgia and Florida mostly with Cnbau I'ine. It also forms part of the forests along the shore, also eovering many of the islands.

Along the west eoast of Florida it is not so eommon, and like Cnban Pine is wauting in many plaees apparently well suited to its growth. From Oeala and Dunnellon up to Live Oak the tree is rarely seen, is more eommon in the flats east of Tallahassee, and still more so between this plaee and Carabelle, where it accompanies Cuban Pine. West of the Apalachicola few trees were seen, and nearing Pensaeola the speeies disappeared entirely.

In North Carolina the tree is well known to moodmen, and is distinguished as "Marsh Pine," oceasionally as "Meadow Pine;" bnt in the towns and to the manufacturers it seems generally unknown, and its logs are never recognized. Iu South Carolina and Georgia the tree, as far as observed, is not well known, aud whell distingnished at all bears the name of "Spruee Pine," a term which, like "Bull Pine," "Bastard Pine," ete, is eommonly resorted to to lide iguoranee in the premises. In Florida, south of Jaeksonville, where the little Sand Pine (Pinus clausa) geuerally, eonsistently, and appropriately reeives the uame of Sprnee Pine, the Pond Pine is not distinguished from Loblolly, both passing under this latter nane. Where it grows with Loblolly, as in the forests of North Carolina and along the eoast, the Pond Pine looks very much like Loblolly. The old trees attain the same height and thickness, the erown, bark, and even the foliage are mneh alike, and the only striking difference is in the eones. Yonng trees of Pond Pine are not distinguished from Loblolly even by observing woodmen, and as long as no eones are borne the distinction is not easy. Bnt besides the nnmerous very persistent cones, of which many stay firmly closed for several seasons, the peeuliarity of branching out from the stem greatly assists in reeognizing this tree in the woods. These spront-like sloots or branehes often eover the trunk for almost its entire lengtlı in a manner often seen in Piteh Piue (Pinus rigida) and also in the true Shortleaf Pine (Pinus cchnatr). In old, stnuted timber, the crown, largely in ennseqnence of this branching, 
is much modificl in sliape; bccomes clongatel, often intcrruptch, and "straggly." In general, the identification is not difficult where it involves merely a scparation of this pinc from its common associates.

\section{BOTANICAL DESCRIPTION.}

Botanically, the Poul Pine is described by Mr. Sudworth as follows:

Leaves three in a sheath ant commonly $6 \frac{1}{2}$ to $7 \frac{1}{2}$ (exceptionally 8 to 10 ) inclies long. Cones very persistent, ofteu remaining on the branches four to six or more years. Fresli, mature oncs are a ricls russet-brown, but with exposure they become ashy gray. Many cones rcmain permanently closel (scrotinous) after maturing, while others open frecly. Closed cones ovate or sometimes rather sliarply couical, 2 to 3 inches long and $1 \frac{1}{2}$ to $1 \frac{3}{4}$ inches in diameter. Opcu cones with strongly reflexed scale and very characteristic in their low, broadly pyranidal outline, the brcadth of the cone usually equaling (sometimes exceeding) the hcight. Scels small, with a narrow, tawny wing (about $\frac{3}{16}$ inch wille and three-fourtlis to seven-eightlis of an inelı long); black or black-brown, with rough and turbercled surface, and two to three indistinct longitudinal ridges.

\section{PROGRESS OF DEVELOPMENT.}

In its uanner of growth the Pond Pine resembles Loblolly iu every respect. Like that species, it is quite bushy when young; shoots up rapidly; makcs fine poles; clcars itself well if erowded; forms an ample, usually clongated erown of medinn sizc; and branches witl nuncrous rather fine twigs. Even wheu stunted it rarely takes on the flat-topped form so oftcn met in serubby Lougleaf woods.

The following examples illustrate its rate of growth:

Au abaudoned field in Gcorgetown County, S. C., a few miles from the salt marshes, was coverel with Loblolly and Pond Pine. Both grew with equal thrift, but on account of too open a stant formed rather largc-crowned, short-bodicd timber. The best trec of Pond Pine ineasured 28 ant 30 inclies diametcr on the stump 2 feet from the ground and had 62 rings, indicating for this tree an age of only about sixty-five years. Most of the trees measurcd over 12, morc than half of them over 15 inehes diameter, while their ages were generally under sixty years. In Bertie County, N. C., numerous trecs werc observed one hundred aud twenty. five to one hundred ạd fifty years old, 20 to 30 inches diameter, and 90 to 110 feet high, furuishing three to four logs per tree.

In keepiug with this rapid growth, the sapwood is wide and, as in Loblolly of the same localities, forms usually over 60 per cent of the volume of the merchantable logs. This accounts for the fact that, outside of North Carolina and a few places of South Oarolina where this trec is cut into boards, the wood of Pond Pine shares the general prcjudice against "Sap Pine," commou throughout the lower South.

Pond Piue is often claimed to be more defective than Loblolly; but as far as this eould be ascertained the diffcrence is not great, and compared with White Pinc, for instauce, both must be pronouuced very sound timber.

The Pond Pine reprodnces itself quite readily and, like Loblolly, eagerly seizcs on abandoned fields, wherever sufficient soil moisture exists. Thougl the older trces are commonly loaded with cones and thercby make the impression of luxuriant sced production, it is doubtful if this pine equals Loblolly in this respeet. As far as observed the youug trees are slower to bear, and entire groves of saplings 10 to 15 fect high are often without fruit.

In this conuection it is of interest that this pine not ouly scnuls ont vigorous aud persistcut shoots from the older parts of its trunk while stauling, but that even logs if left on the grouud continue to sprout, 5 to 10 slioots often brcaking through the bark on a space of a few square inches, aul still more that the stumps of small trecs ( 1 to 2 inches diancter), whether cut or burncl, send out 20 to 30 vigorous shoots during one season. Geuerally one or two of thesc take the learl and the rest die off. Whether these surviving shoots ever grow into trees of any size is not known, the tallest trees of which this origin could be clearly dcmonstrated bcing only about 15 feet high. 
In its station or habitat the Pond Pine is at present limited to the low, wet, sandy flats; it is not met on dry, sandy, rolling pine lands, nor does it, like Loblolly, take to the rich river bottons and hanmoeks or the tertile red-elay lauds. Its name is misleading, in so far as it does not, like the Cuban Pine, go right into the water or ponds. On eonstantly overflowed tracts, like the Okefinokee, or the interior of cypress ponds, the Pond Pine is not found. As to its assoeiations, the Pond Pine is qquite independent. Generally it oeeurs only with other pines, particnlarly Loblolly in the northern part of its range and Cuban Pine further sonth; but, as stated before, it is fonnd with Longleaf on the vast flats of southern North Carolina and also mixed with hard woods, as in eastern North Carolina. It is rarely alone and no large forests of Pond Pine seem to oeeur. In Genrgia and eastern Florida it is the eommon assoeiate of Cuban Pine, where this latter forms the nalrow fringe of river swamps and lammoeks, separating often by only a few rods the Longleaf from the cypress and hard woods of these tracts.

\section{ECONOMIC IMPOR'TANCE.}

In former years this tree, like Loblolly and Shortleaf, was not bled for tin'peutine, but of late the scarcity of Longleaf Pine lias indneed the people of South Carolina and other States to extend their nperations even to these less-remmerative speeies. The yield from Pond Pine is fair both in quautity and quality, but requires unore labor, the "streak" or wound requiring renewal at least twiee a week. Operators clain that the tree does not bleed as long during the same season as the Longleaf, nor does it endure the operation for as many seasons. On this latter point, however, ohservations are as yet not suffieient to warrant generalizations. With its ready reproduetion, rapirl growth into goorl lumber-size trees, and its ability to oeeupy poorly ilrained, otherwise almost valueless lands, the P'ond Pine deserves attention in all future forest operations of its region. 



\section{N DEX.}

Page.

Age, effect on pine wood

Alabama central pine helt, descriptiou

Longleaf Pinc forests, description.

north, Longleaf Pine forests, description .............

shipments of timber and Inmber in 1892

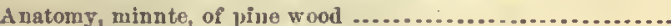

Annnal rings of wood, description....

$$
\text { false }
$$

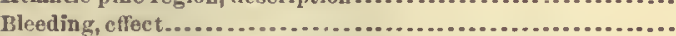

Botanical lescription and morphology of Cnban Pine......... Lohlolly Pine........ Longleaf Pine.

of Shortleaf Piue ...................... Spruce Pine

diagnosis of Principal sonthern pines.................. names of pines, list.

Boxing, effect .

Branch, root, and stenı system of Loblolly Pine............... Longleaf Pine..............

Brunswick, Ga., exports of lumber for ycars 188t-1894 ........ Contral pine belt of Alahama, description...

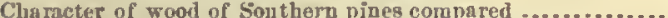
Characteristies of distribution in different regions of Shortleaf Pine.

Charcoal burning, nse of Longleaf Pine

Cbarleston, S. C., Inmber tracle, 1880-1894 number of barrcls and total valne of rosin stripperd, 1880-1894 casks and total value of spirits turpentino shipped, 1880-1894.. trade in naval stores, $1880-1894 \ldots . . . . . . . . .$.

Classifeation and nomenclatnre of Cuhan Pine ................. Loblolly Pine .............

Longleaf Pine Shortleaf Pinc

of rosin, or colophony Climate and soll, effect on development of Longleaf Pinc...... required hy Lohloliy Pine.

Sliortleaf Piue...................

Spruce I'ine

soltalle to growth of Cirhan Pine....

Colophony, or rosin, descriptive classificatlon. Crude turpentino, amount slipped from Wilmington, N. C.,

with total valne, 1880-1894.

Cuhan Pinc, article by Charles Mohr.

characteristics of wood

classiffcation and nomenclature.

conditions requirell for development

description and morphological characters........... of forers.

economio importance geographlical distrihntion......................... growth by decades for 120 years. from 4 to 20 yea $\mathrm{rs}$

notes on additional, by Filthert Roth jurogress of development......................... products.

pate of growt b.

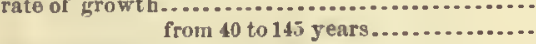

requirements of...

reminous proulnets.

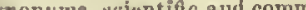

Darien, Ga., export of lumber, 1884-1894
Page.

Distillation of turpentine, methods ...................... 70

Enemies of Loblolly Pine, remarks .......................... 130

Lougleaf Pine, retuark»...................... 61

Shortleaf Pine, remarks ....................... 108

spruce Pine, remarks....................... 140

Exploitation methods, injurinns, in Longleaf Pine forests..... 61

Exports of lnmher from Sa raunal, Brunswick, Darien, and St. Jarys, 1884-1894.

Hpirits turpeutine aud rosin from Mobilc, 1880-1894. timber and Immber from Pensncola, 1880-1893.......

Mobilc, Ala., amonnt and value, $1880-1894 \ldots . . . .$.

False rings......................................... $\quad{ }_{151}^{4}$

l'ernow, B. E., lutroduction to hulletin.................... 11

Fire, lujury to Lougleaf l'ine forests ...................... 62

Florida, easteru, Longleaf Pire beit .......................... 36 western, Longleaf Pine firrests, description.......... 37

Flowers of Cuhan Pine, description ....................... 81

Loblolly Pine, description....................... 123

Shortluaf Pine, description..................... 101

Longleaf Pinc, description....................... 51

Forestry, description................................. 11 time for the application......................... II

Forests, effect of prodnction of naval stores................ 72 Loblolly Pine, natura! reprodnction................. 131 Lougleaf Pine, in Alabama, description............. 41 Georgia, description................ 34 Lonisiana, description............. 43

Mississippl, descriptiou ............. 42 Texas, descriptlon................. 45 injurions methods of exploitation..... 61 injury from firo.................... 62 Iive stock ............... 62 natural reprod uction.................. G4 turpen tine orcharding................ 69

Shortleaf Pino, managerient..................... 110

Fuel value of Longlcaf $P$ ine wood.......................... 48

Fungl injnrious to Longleaf Pine ........................ 63

Georgla forcsts of Longleaf Pino, description................ 34 shipments of lumber, $188 t-1894 \ldots \ldots \ldots \ldots \ldots \ldots \ldots \ldots . \quad 36$ statistics of Longleaf Pine.......................... 35

Graln of the pine woods, remarks....................... 148 Growt 1, rate compared................................... 22 Gnlf reglon, eastern, maritine pine belt, description........... 30 Heart and sap wood, general remarks ....................... 143 Helgbt of Longleaf Pine, by decades ........................ 60 History, economic, of Loblolly Pine...................... 116 of Longleaf Pine.................................. $\quad 29$ of naval-stores industry........................ 68 the use of Lohlolly Pine........................... $\quad 115$ Shortleaf Pine......................... 93 Insects injurious to Longleaf Pine trees................... 63 Loaves of Lohlolly Pine, description...................... 123 Longleaf Pine and their modifeations............. 49 Shortleaf Pine, description.................... 101 Leaf products of Longleaf Pine........................... 48 Ligbt, relation to Loblolly Pine and assoclated species......... 130 Shortlea $P$ Pine and associated specics....... 108 Lightwood, formation and usos.......................... 47 LIve-stock injury to Longloaf Pine forests . ................. 62 Lohlolly Pine, article by Clarles $M$ tohr.................... 113 associatid sprelcs and relation to light ........ $\quad 130$

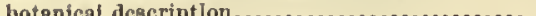



description of flowers and leaves............. vood.

economic importance. enemles .... growth. by decades, to 120 years............... from 5 to 50 Jear. ..................... 50 to 156 years................... hoight, dinmeter, and euhic contents, by decades. history of its nso .............................. lesves, descriptlon1 ........................... measurements of trees from different regions. 118, nomenclature and elasalfication.............. notes on, addiltionsl, hy Filihert Roth.......... products...

rate of growtl...

reproduction, natural

root, stem, and lranch system................ soil and clinnto required .....................

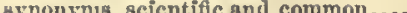
uses and raluo of wood.

Locality, inflnence on value of plnes .......................

Longleaf Pine, article by Charles Jiohr....................... associsteds pecies

belt of easteru Florida deseription.

blown down by storms ......................

botanicsl deseriptlon and morphology .

conditions of development. cubic contents, by decades....

demands upon soll snd elimate. ecoumic luportance efiects of usval-stores ind ustry eneinies.

estimato of timber standing.

flowers, description.

. injnriona methods of exploitation...... management ........................... nstnrnl production .................. 64-131 of Alahama, description................ 38,41 eastern Lonisisns, description........ Georgia, description. Mississippi, description. North Carolins, description........... Soutl Carolins, description. Texas, description. westeru F"lorids, description........ western Louisiana, description...... geographical distribntion

grow th and development.

rete of gromth by dect

stage of rnpid grow th

stage of slow growth height, diameter, and cubic contents, by decades. injnred by fungi (P'olyporus) .................. insects injurions

leaf proincts.

lcarca and thelr modification.................

lnmber producod iu Lonisiana in $1892 . . . . . .$. . Texss in $1892 \ldots . . . . . . .$. measurements of trees............ $38,39,41,44,45,46$ from 100 to 200 yesrs old. 200 to 266 years old.

young trees.

nomenclaturo sud classiffcatiou................. notes on, sdditional, hy Filibert Roth........... products .................................... rate of growth............................. 59,60 region west of tho Mississippi, doseription..... reproluction, natural.

resinons prodncts............................ root, stem, and branch systcm............... sciontifle sud common synonyms... soeds, description
129 123 125 115 130
Paga

ngleaf Pinc, statistice of Georgia ...................... 55 stat istics of Milaslssippi..................... 42 South Csrolina.................. 33 summerwood, per cent, and speciflo gravity in varions ps rts of trees....................... 147 turpentine orcharding in furests.............. 69 varfation of speclfic gravity with anmmerwood and per cent and sge of sectlon.............. 147 wool, deseription........................... 53 fuel valne............................ 48 uses and value...................... 40

Louisiana, oastorn Longleaf PIne forest 8 , description.......... 43 Longlesf Plne lumber, production in $1892 \ldots \ldots \ldots . .$. Low pine hartens, deaoription.

Lumber, Longleaf Pine, productlon in Lonislans in $1892 . . . . .$. Texas in $1892 . . . . . . . .$.

Bhipments from Alnbama in 1892

Mlississippi in 1879-80 and 1883-1893..

Mobile in 1880-1894 ..................

Pensacols in $1880-1893 . . . . . . . . . .$. Savannah, Brunawiek, Darien, and St. Marya, 1884-1894

sbipped to foreign and domestic ports from Charleston, S.C., $1880-1894$.

shipped to foreign and domestle ports from Wilming.

ton, N. C., 1880-1894 ............................. Isritime pine belt of the oastern Gulf region, flescription..... Ysrshl Pine ............................................... 169 Messurements of Loblolly Pine, by decades................. $\quad 129$ from differont regions........ 118, 119

Longlesf Pine trees $\ldots . . . . . .38,39,41,44,45,46$ from 100 to 200 jears old. $\quad 58$ 200 to 266 years old. 59

Shortleaf Pine trees at different ages........ 100 of different regions...... 89-98

Spruce Pine trees at different ages.......... 139

trees from virgln forests.................. 35

young Longleaf Pine treea................. 57

Mechsnical properties of wood of Sonthern pines compared.... 14

Medullary rays ........................................ 149-154

Mississippi L.onglesf Pine forests, description.............. 4 ?

lumber shipments, 1879-80 and 1883-1893.......... \$3

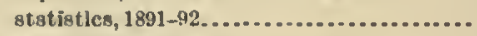

statistics of Longlosf Pine .......................

Mobile, cask of spirits of turpentine exportod, 1880-1894...... oxports of naval stores, $1880-1894$. rosin in harrels, 1880-1804...

Mohr, Charles, article on Cnbın Pine (Pinus heterophylla)...... Loblolly Pine (I'inus tceda) ........... Ionglesf Pine (J'inus pulustris) ...... Shortleaf Pine (Pinus echinata)...... Spruce Pine (Pinus glabra) ...........

Moisture and weight of pines... influence on strength of pine..........................

Morphology snd botanicsl description of Loblolly Pine........ Longleaf Pine....... of Cnhan Pine

Sistal stores, definition

effects of produetion npon the timber and life of tree and the condltions of forests............... exports from Charleston, S. C., $1880-1894$....... Mobile, Aln., $1880-1894 . . . . . . . . .$. Savsnnah, Ga., 1880-1894.......... Wilmington, N. C., snd total value,

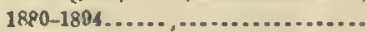

histors of the indnstry .......................

statistics ...................................... Nomenclatnre and classification of Loblolly Pise............. Longloaf Pine............. Shortlesf Pine.............

of Cuhan Pino................................

Sonthern pinos ............................. Nortb Carollna Longleaf Pino forests, deacrlption............ Orcharding tarpentine in forcats of Longlesf I'ine............. improved metheds................... Orchards, turpentino, cost of establishing a plant for working-

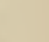

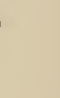


Orchards, tnrpentine, tools nsed

Pensacola, Fla., exports nf timber and lumher, $1880-1893 . . . .$.

Pine harrens proper...........................

helt, central, of Ala hama ...............................

helts of tbe South, description..........................

Cnban. (See Cnhan Pine.)

diagnostic featnit of the wood.

distribution of strength and weight throughout the tree. effect of age on wood

forests in Virgiuia, description...........................

graiu of woods, remarks ..............................

infinence of locality on value

Lohlolly. (See Loblolly Pine.)

Longleaf. (See Longleaf Pine.)

minute anatomy of wood .

range of value fer weight and strengtb....................

relation $\mathrm{nf}$ strength to weight.

Serub, only valnable for firewood......................

Shortleaf. (See Shortleaf Pine.)

Spruce. (See Sprnce Pine.)

tar, methods nf prodnction

timber, estimated annual consumption....................... estimate of quantity............................. statistics

use of the worl.

weipht and moiatare

weight and strength of wood at different beigbts in the tree ............................................ relations ..........................................

T'hite, habitgt.

Pines, leest common names.................................. botanicai names.................................... local common uames

uechanical properties .................................

must important timher of the world ................... notes on the structure of the wood of the flve Southern, article hy Filihert Ilotb ............................. remarks on shrinkage................................... Southern, nemenclature wool characteriotic

statistics........

Pinus echinata, article by Charles Mohr....................... sfnonyms, scientifio and common

glabra, article by Charles Mohr (ree Sprnce Pine) ........ aynonyms, scientific and common ...............

helerophylla, article hy Charles Mohr (see Cnban Pine) .. botanical diagnosis....................... synonyms, scientifio and common...........

palustris, article by Charles Mohr (see Longleaf Pine) ... botanical diagnosis .......................... synonyms, sclentific and commoh..............13,

erotina, observations on, hy Filibert Rotl ............. 169

strobus, hahitat

toda, article by Charles Mrobr

hotanical diagnosiн............................

common names and synonyms................... 13,

13itcb, com mon, bow obtained

Pond Plne

Remin dncts

Reain from Lon gleaf Pine description and oomposition......

Reslnons prodnets of Cnban Pine.

$$
\text { Loblolly Pine. }
$$

Ixings, annual, description. false

Ront, stern, and bruncb syatem of Lobloliy Pine -.0.0.0.0.0. Longleaf Pino

Posin or colopbony, descriptlon and classlfication. rleston, $\mathrm{S}_{-} \mathrm{C}_{\mathrm{B}}$ in barrcle, and valne, 1880-1894

Muhile, Ala, in barrels, 1880-1894....... Savannah, Ga., in barrels, 1880-1894.... Wilmington, N. C., and total value, 1880-1894...........................

Roth, Fllibert, article ou the structure of the wood of five Sont beru pinew......................................
Page. 2
Roth Page. Lohlolly Pino

Longleaf Pine............... 74

Shortleaf Pine .............. 111

observations on tbe Marsh or Pond Pine (Pinus serotina).

Sap and heart wood, remarks................................. 169

Savannah, Gae, amount of naval stores exported, $1880-1894 \ldots . . .36$

exports of lum her, 1884-1894................. 36

number of harrels of rosin exported, 1880-1894. $\quad 36$

number of caeks of spirlts tnrpentine exporfel.

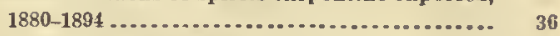

Sbortleaf Pine, article hy Charles Mobr.......................

hotanieal description....................... 101

characteristics of descriptions in different regions................................... climate and soil suitable $\ldots \ldots \ldots \ldots \ldots \ldots \ldots \ldots . .107$ conditions of developrent ................... 107 crowding ont ether speciea..................... 108 description of flowers and leaves............. 101 characteristics of wood.......... 103 economic importance........................ 93 enemies ................................ 108 forest management.......................... 110 geographical distribution.................... 93 growth after 120 years ................... 106 from 8 to 50 years................... 105 50 to 120 vears................... 106

beigbt, diameter, and onbic contents of avorage trees at various ages ........................... bistory of its use ........................... measnrement of trees of diffcront regions....... nomenclatnre and classlfication............... notes on, additional, hy Filihert Roth..........

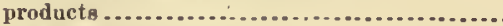
pregress of development ...................... rate of growth dn riug different periods of life.. relation to light and associated speeles......... requirements as to llght........................ sbrinkage of wood ........................... synonyms, seientific and common .............. Soil and climate, demands hy Longleaf Pine .................. required by Loblolly Pine ................... Spruee pine...................... 14 suitable to Shortleaf Pine.................. 107

regnired for development of Cnban Plne................ 88 Sontb Carolina Longleaf Pine foresta, description .............. 33 statistics of Longleaf Pine .................. $\quad 33$

Sontbern plnes, nomenclatnre.............................. 13 wood characteristics ....................... 13

Spring and snmmer wood, difference ....................... 146

Spruce Pine, article by Cbarles Mohr....................... 135

botanical description ......................... 138

clinate and soil required ..................... 140

distrihution $\ldots \ldots \ldots \ldots \ldots \ldots \ldots \ldots \ldots \ldots \ldots \ldots \ldots \ldots . . .137$

ecouomic importance........................ 137

enemies -.........

growth (lieight, diameter, and enbie contents) at different ages.................................. histery .................................

progress of development ......................... 139

requirements of development .................... 140

statisties of supply and production ............. 23

synon yms, scientifio and conmon.............. 130

Stem, root, and brancb system of Loblolly Pine................. 121

Longleaf Pine .............. 49

St. Marys, Ga, exporta of lumber, 1884-1894 ................... 36

Storms, injurions to Longleaf Pine forests ................... 62

Strength of wool of Southern pines ......................... 14

Sunmer and spring wood, difference....................... 146

Summerwood, per cent, and age of section in Longleaf Pine.... 147 apeclfic gravity of various parts of Longleaf Plne............... 147

variation, per cent, from pith to hark............ 146 with rate of growth in Longleaf Piue tree.........

0

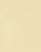


Page.

Synonyms, selevtlfic and common, of Cuhau Plnv (Pinus heterophylla )................. loblolly l'ine (l'inus tarda) $\ldots$............... Longleaf l'ino (Pinus Sluortleaf l'ine (l'inus echinata) ............... Spruce plne (J'intusglabra) Tar, amount slblpjed from Tilmington, N. C., 1880-1894 . . Iint, pise, mothods of production...

'T-xas forents of Lougleaf line deseription ...... lumber prol netion from Longleaf 1 ine ............... Timber, effects of produetion of uavsl atores on tho timber, lifo of the treo, and the conditlons of the forests ......... estimate of Longleaf l'ino standing................. oxported from 1'ensacola, Fla., 1880-1893..............

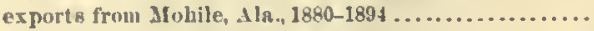
reglons, supply and probinction..................... Bhlpurents froun Alaham 1892

Tracheids.

Turpentiue, cost uf estahlishingr nlant for workingsurchsri. crutie (or resin) from Longlesf Pine, composition. oil. (Äee spirits.)

metbods of distillation .

orelsard, cost of extahlishing a plant for working.. orcharding, an improved methoul..........

injury to trees and forests ...........

iu the furests ot Lougleaf Pine.......

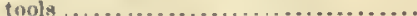
splrits, anoont shipped from Wilmington, $\mathrm{X}$. C., and total value, 1880-1894............. 78 114 28
Jagre.

Turpenthe, spulrlts, nnmher of casks shlpped, and total raine from Charleaton, $\$. C., r880-1894 ......... numler of easka shl pped from Mohile, $\mathrm{Ala}$.

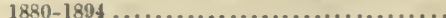
or oh, chemleal compostion ..............

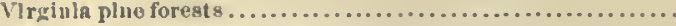

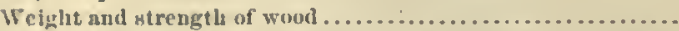

Tihuington, X. C., shlpuente of lninher to foreign aud domes. tlo ports, 1880-1894...................

trade in naral stores, $1880-1894 \ldots \ldots \ldots \ldots$

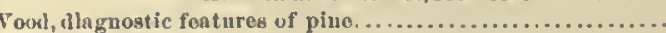
offect of age......................................

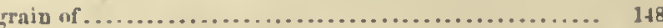
of Cuhan Pine, characteristics................... 83

Lohlolly Pine, rliaracterlatics.................. 125 description ..................... 53 usu ani valne.................... 119

Longleaf Piue, characteristicg ................ 53 fucl $r$ shlut $\ldots \ldots \ldots \ldots \ldots \ldots \ldots \ldots \ldots . \ldots \ldots+48$

minute auatouy of ............................. 148

piue, reluarks on grain........................ 148

Sliortleaf Pine, eharacteristic................. 103

Southern jlnes, eharacterlstics ................. 13 imechanical proporties............ is relation of utrength to wright...... is influence of lonality.............. 18 moisture............ 18 gliriuknge..................... 20

the fivo Sonthom pinos, articlo hy Filihert lioth..... 143 sap aud heart, ronarks......................... 143 spring abd aumuer, tliflerenve.................. 146 weight and gtrength at different heights in treo........ 15 
4 

SD

397

P551:6

1897

Forstrs
Mohr, Charles Theodore

The timber pines of the southern United States

PLEASE DO NOT REMOVE CARDS OR SLIPS FROM THIS POCKET UNIVERSITY OF TORONTO LIBRARY 


.

